Maria De La Ó Ramallo Veríssimo

\title{
O OLHAR DE TRABALHADORAS DE CRECHES SOBRE O CUIDADO DA CRIANÇA
}

\author{
Tese de Doutorado \\ Escola de Enfermagem \\ Universidade de São Paulo
}

Orientadora:

Profa. Dra. Rosa Maria Godoy Serpa da Fonseca

São Paulo - SP

2001 
Ficha catalográfica preparada pelo Serviço de Biblioteca e Documentação da EEUSP

Veríssimo, Maria De La Ó Ramallo

O olhar de trabalhadoras de creches sobre o cuidado da criança / Maria de La Ó Ramalo Veríssimo.-São Paulo : M. De La Ó R. Veríssimo, 2001.

$199 \mathrm{p}$.

Tese (Doutorado) - Escola de Enfermagem - Universidade de São Paulo.

I. Título. II. Creches. III. Cuidado da criança. IV. Educação Infantil. V. Bem-estar da criança. 
Para mim, uma tese não tem começo nem fim muito definidos, assim como tudo o que fazemos na vida. Ela vai começando quando olhamos para alguma coisa que nos inquieta, e vai se tornando à medida que a inquietação se transforma em perguntas, em problema, em objetivo, em método...

Uma tese é um pedaço. Mas não é um pedaço só de mim, a autora. Ela é um pedaço de muita gente que está perto de mim. Gente que me ajuda a ficar inquieta com o que vejo, porque também vê e se inquieta; que me ajuda a fazer perguntas, a problematizar, a pensar em caminhos...

Assim, às vezes, é difícil perceber todas as pessoas que participaram dessa construção, por isso, peço desculpas se me esquecer de citar alguém.

Agora, algumas pessoas são, sem sombra de dúvida, facilmente identificáveis como aquelas que ajudaram a tornar possível que esta tese tivesse um fim, ainda que provisório, próprio do tempo histórico e cronológico, e do tempo de maturidade que eu, como autora, pude alcançar.

À professora Rosa Maria Godoy Serpa da Fonseca. Mais do que orientadora, acolheu, confiou, ajudou, respeitou, questionou, leu e releu, e, pacientemente, esperou "os tempos" de que precisei.

À Coordenadoria de Assistência Social da USP por possibilitar a realização deste trabalho.

Às coordenadoras e educadoras das creches que compartilharam comigo seu tempo, pensamentos e vontades, tornando possível a realização desta tese.

A minha mãe, irmãos e cunhadas, não só por todo seu amor e carinho, mas também por compartilhar comigo e com o Oswaldo o cuidado de nossos filhos.

Às amigas que, além de me possibilitarem maior tempo para dedicação a este trabalho, têm muitas razões para serem lembradas

Cecília Helena de Siqueira Sigaud, por seu companheirismo, apoio, carinho e trocas construtivas.

Magda Andrade Rezende, por trazer o tema da creche para minha vida, e ajudar-me a compreendê-lo com uma nova visão; por emprestar-me sua biblioteca, seu tempo, seu carinho, e, mais do que tudo, ajudar-me a confiar em mim.

Moneda Oliveira Ribeiro, por sua presença, disponibilidade, bom humor, acolhida, sugestões e força.

À Anna Maria Chiesa, também amiga, mas especialmente pelas valiosas contribuições na discussão do projeto de pesquisa e pela riquíssima experiência na oficina pedagógica.

Ao Paulo Cobellis Gomes, não só pelas contribuições na discussão do projeto como também por todas as oportunidades em que me ajuda a aprender.

Às docentes do Departamento de Enfermagem Materno-Infantil e Psiquiátrica, pelo companheirismo e pelo incentivo.

À Roberta pelo paciente trabalho de organizar as referências bibliográficas e, claro, em nome dela e no meu, à Anadir, bibliotecária da EE, que tantas vezes fomos consultar.

A todo o pessoal da biblioteca, da secretaria da pós-graduação, do Centro de Informática, pela ajuda

Ao Cléber, pelo árduo trabalho de transcrição e digitação.

Ao pessoal da secretaria do Departamento ENP: Vânia, Etevaldo, Fábio e Marcelo, por socorrerem-me inúmeras vezes. 
Veríssimo M De La Ó R. O olhar de trabalhadoras de creches sobre o cuidado da criança. São Paulo, 2001. [Doutorado]. Escola de Enfermagem da USP.

\section{Resumo}

Este estudo teve como objetivo apreender e analisar as representações de profissionais que atuam em creche, acerca do cuidado da criança. O referencial teórico adotado foi a Teoria das Representações Sociais de Moscovici. Os dados foram coletados junto a 7 coordenadoras e 9 educadoras, de três creches vinculadas a uma universidade pública, no Município de São Paulo. Com as coordenadoras, a coleta de dados foi realizada por meio de entrevistas individuais semi-estruturadas. Com as educadoras, foi realizada uma oficina pedagógica, estruturada em 4 encontros. Os tópicos estabelecidos para cada encontro visaram compreender o que os sujeitos do estudo pensam, sentem e fazem, em relação ao cuidado da criança. Os encontros e as entrevistas foram gravados, transcritos na íntegra e os dados submetidos à análise de conteúdo, segundo a técnica de análise temática. Foram obtidos os seguintes temas: $\mathbf{A}$ creche, $O$ trabalho na creche, $O$ cuidado da criança na creche e $A$ creche e a família. Com base na análise, identificou-se que, para as coordenadoras, o cuidado é definido como as ações realizadas para atender às necessidades físicas e emocionais da criança, além de estabelecimento de vínculo afetivo. Cuidado e educação têm igual valor e se integram porque as crianças aprendem algo durante as ações de cuidado. Para as educadoras, cuidar é prover o bem-estar da criança (alimentar, higienizar, permitir o descanso, manter a segurança física). Consideram o cuidado como uma etapa preliminar das atividades pedagógicas, que permite à criança sentir-se disposta a aprender. Para ambos os grupos, o cuidado profissional é diferente do cuidado oferecido em casa porque se fundamenta em princípios científicos e rotinas institucionais. Conclui-se que as trabalhadoras, apesar de cuidarem extensivamente das crianças, não reconhecem essas ações como cuidado, o que se deve à falta de reflexão sobre um referencial teórico-conceitual para fundamentar o cuidado na creche.

Palavras-chave: creches; cuidado da criança; educação infantil; bem-estar da criança 
Veríssimo M De La Ó R. The day-nurseries workers' viewpoint on child care. São Paulo, 2001. [Doctorate]. Nursing School of USP (University of São Paulo).

\begin{abstract}
This study aimed to ponder and analyze the representations of the professionals actuating in day nurseries concerning the care of the child. The theoretical referential adopted was the Theory of the Social Representations by Moscovici, bearing in mind that care of the child is a phenomenon ever-present in humanity's history that has been re-interpreted as much in the light of science as in that of the knowledge of common sense. The data was gathered from 7 coordinators and 9 educators (all 16 were women) from three day nurseries connected to a public university in the São Paulo municipality. The data obtained from the coordinators was collected through semi-structured individual interviews. That from the educators was effected through a pedagogical workshop structured into 4 group encounters. The topics set out for each meeting aimed at understanding what the subjects of the study think of, feel and do with reference to the care of the child. The meetings and interviews were registered on tape, integrally transcribed and the data submitted to the analysis of the contents, according to the technique of thematic analysis. The following themes were obtained: The day nursery, The work in the nursery, The care of the child in the nursery and The Nursery and the family. Based on the analysis it was shown that, for the coordinators, the care is defined as the actions taken to attend to the child's physical and emotional necessities and for the establishing of an emotional attachment. Care and education have the same value and integrate because the children learn something during the care actions. As concerns the educators, to care is to provide the child's well being (nourishment, hygiene, rest, maintain physical security). They consider the care as a preliminary step to pedagogical activities that allow the child to feel apt for learning. For both groups, the professional care differs from that given at home because it is based on scientific principles and institutional routines. It is concluded that the workers, in spite of taking extensive care of the children, do not recognize these actions as care, this being due to the fact that no theoreticalconceptional referential is being used to establish the care in the nursery.
\end{abstract}

Keywords: child day-care center; child care; child rearing; child welfare 


\section{INTRODUÇÃO}

SUMÁRIO

Apresentação ……............................................................................................ 1

Sobre 0 cuidado ...................................................................................................

Sobre 0 cuidado da criança na creche........................................................................... 9

O Referencial Curricular Nacional para a Educação Infantil e o cuidado................................ 14

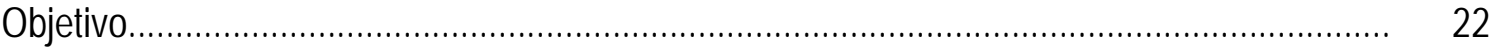

\section{O PERCURSO METODOLÓGICO}

Referencial Teórico-metodológico.................................................................................... 23

Cenário do estudo........................................................................................... 27

Inserção da pesquisadora na realidade das creches....................................................... $\quad 29$

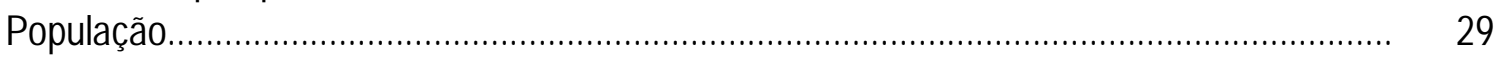

Aspectos éticos............................................................................................ $\quad 30$

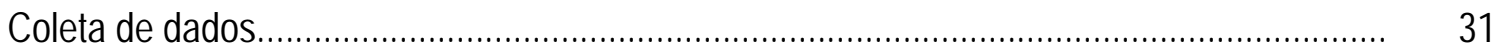

Análise dos dados..............................................................................................

\section{APRESENTAÇÃO E DISCUSSÃO DOS RESULTADOS}

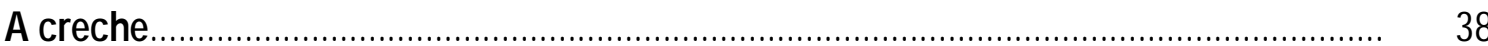

1. Para as coordenadoras

A vida da criança na creche.................................................................................. 47

Controvérsias sobre a creche........................................................................... 51

2. Para as educadoras

Funções da creche..................................................................................... 59

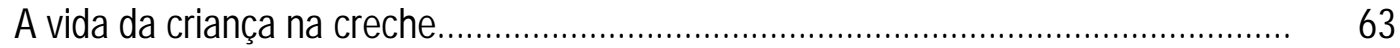

Controvérsias sobre a creche........................................................................... $\quad 75$

O trabalho na creche................................................................................. 78

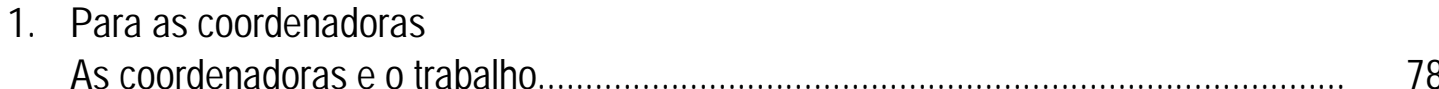

A organização do trabalho................................................................................. 84

A formação para o trabalho na creche................................................................ $\quad 90$

2. Para as educadoras

As educadoras e o trabalho.......................................................................... $\quad 97$

A organização do trabalho............................................................................. 108

A formação para o trabalho na creche................................................................ 117

O cuidado da criança na creche............................................................................ 120

1. Para as coordenadoras

O cuidado e 0 trabalho com as crianças............................................................... 135

Relações entre cuidar e educar........................................................................... 138

2. Para as educadoras

O cuidado da criança ...................................................................................... 143

Relações entre educar e cuidar......................................................................... 146 
1. Para as coordenadoras

Expectativas, percepções, sentimentos e ações relacionados às Interações entre a equipe da creche e a família........................................................ 150

Medidas para favorecer a interação entre a creche e a família.................................... 160

2. Para as educadoras

Expectativas, percepções, sentimentos e ações relacionados às

Interações entre a equipe da creche e a família...................................................... 163

Medidas para favorecer a interação entre a creche e a família.................................... 173

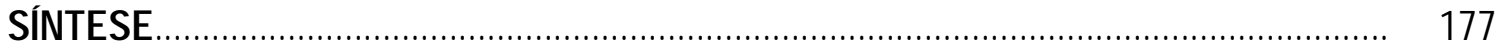

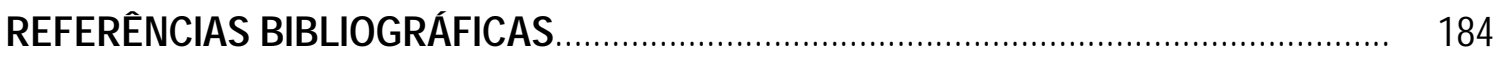

ANEXOS 


\section{Apresentação}

Desde o curso de graduação em enfermagem, sentia como um grande desafio compreender a própria profissão e, nesse sentido, compreender 0 cuidado, seu âmago de trabalho. Aprender a cuidar era a principal questão presente durante o curso de graduação e, ainda hoje, após anos de trabalho no ensino a na assistência de enfermagem, continuo buscando aprofundar minhas reflexões e compreendê-la melhor. Por essa razão, surgiu a proposta deste trabalho.

Na primeira fase do curso, interpretava o cuidado como atividades que deveriam ser realizadas junto aos pacientes; basicamente, intervenções que visavam atender demandas geradas por um agravo à saúde. Entretanto, acreditava que era possível aprender formas de cuidar que tornassem o cuidado mais personalizado, não resumido a uma visão tecnicista, com foco no procedimento. Embora consciente de que a segurança dos pacientes dependia de técnicas corretas, não me satisfazia em apenas aperfeiçoar a realização de procedimentos.

Ao conhecer a Abordagem Centrada na Pessoa, de Carl R. Rogers (Rogers, 1978), passei a utilizá-la como referencial para desenvolver o trabalho. Isso porque esse referencial explicava aquilo que buscara até então: o cuidado tendo como foco a pessoa e não sua doença.

Assim, durante anos, no ensino e na assistência, fui construindo uma maneira de cuidar que superasse a visão, restrita, da doença como foco. E fui compreendendo o cuidar não apenas como a realização de atividades mas como uma atitude de ir ao encontro do outro, de estar com ele e ajudá-lo a viver sua experiência de vida e de saúde/doença.

Nos últimos anos, venho trabalhando como docente de enfermagem na área de saúde da criança, em unidades básicas de saúde e em creches. Nas creches, passei a ter contato com educadoras e professoras, pessoas que realizavam o cuidado da criança. Nesse contexto, observei diversas situações que começaram a despertar meu interesse em compreender as relações das professoras com o cuidado das crianças. 
Exemplificando, em uma creche filantrópica na qual estive com alunos de enfermagem, algumas das pessoas que cuidavam das crianças não tinham formação sequer no nível de ensino médio nem haviam recebido capacitação específica para o trabalho. Esta é uma realidade muito freqüente em nosso meio.

Nesse local, o que mais me chamou a atenção foi a maneira rigorosa como algumas atividades eram realizadas com as crianças. Uma situação que exemplifica bem essa percepção é a que relato a seguir:

A educadora chama o grupo de crianças de 3 anos para sentar-se em círculo, no chão, e senta-se com elas para ouvirem uma música. Passados alguns instantes, algumas crianças começam a conversar e são chamadas à atenção pela educadora que lhes diz que não conversem. Uma criança levanta-se. A educadora lhe ordena que se sente pois "é hora de ouvir a música". As crianças permanecem mais alguns instantes quietas. Logo começam a conversar. São repreendidas. E isso se repete durante uns dez minutos.

Diante desse exemplo, que não constitui um momento isolado pois situações semelhantes a essa eram as mais freqüentes nesse serviço, pareciame que isso ocorria porque as educadoras não conheciam ou não compreendiam as necessidades das crianças. Como era possível cuidar sem entender as necessidades de quem está sendo cuidado?

Em outra creche, cujas condições de trabalho eram bem mais adequadas, seja no aspecto de formação das professoras (todas tinham completado o ensino médio e algumas tinham curso superior), seja na proporção menor de crianças para cada professora, também verifiquei fatos intrigantes. Durante as atividades relacionadas à higiene, sono e alimentação, tinha a sensação de que as professoras não se envolviam da mesma forma com que se envolviam com outras atividades. Nos momentos de banho e troca de fraldas, não havia conversas nem brincadeiras e tudo era feito muito rapidamente indicando que o único objetivo era a atividade em si. Durante as refeições, era muito semelhante: o foco das intervenções das professoras era fazer com que as crianças comessem. Ouvi comentários a respeito destas preferirem ficar com os grupos etários maiores, "porque as crianças do berçário têm (requerem) muitos cuidados". Tais comentários pareciam-me um 
menosprezo pelo cuidado, como se esse tivesse menor valor que as atividades vistas como educativas (realizadas com as crianças maiores). Isso foi reforçado por outras falas tais como "com os bebês não dá para propor atividades de pintura ou massinha, pois eles ficam pondo tudo na boca".

Certamente, o fato de estar na presença de outras pessoas, no caso eu e as alunas, poderia ser um modificador do comportamento habitual. Mas em outras situações, as interações com as crianças eram bem diferentes. Por exemplo, as professoras participavam ativamente de brincadeiras com as crianças, conversando, interagindo, brincando junto, fato que denotava uma compreensão distinta acerca dos objetivos dessas atividades.

Frente a essas experiências, algumas questões foram surgindo para mim:

O que é cuidar da criança, no âmbito da creche?

Será que cuidar é tido sempre como uma função de menor valor no contexto da creche?

Cuidar e educar no âmbito da creche são compreendidos como ações distintas ou integradas?

Que contribuições a enfermagem pode oferecer para a melhoria da qualidade do cuidar da criança na creche?

Além disso, considerando que o cuidado é o objeto do trabalho da enfermeira, então não seria necessário a participação dessa profissional junto às creches?

Tendo como pano de fundo tais questionamentos, recorri à literatura buscando compreender aspectos que poderiam relacionar-se aos mesmos, para, ao final, formular questões mais específicas para desenvolver esta investigação.

A literatura científica mostra que o contexto da creche vem tomando um vulto cada vez mais importante enquanto local onde as crianças crescem e se desenvolvem. Por essa razão, um grande número de profissionais, tais como educadores, psicólogos, cientistas sociais, médicos e enfermeiras, vêm trabalhando nesses serviços e estudando o tema, embora esses estudos ainda não formem um corpo de conhecimentos que responda a todas as questões relativas ao tema. Para fundamentar o presente estudo, utilizou-se fontes 
bibliográficas esclarecedoras sobre o cuidado e sobre o cuidado da criança na creche.

\section{Sobre o cuidado}

Conforme afirma Rossi (1991), o cuidado é "nossa disciplina", ou seja, a disciplina da enfermagem. Essa autora aponta que o cuidado "sugere atitudes e sentimentos que podem levar a uma relação entre pessoas, isto é, a uma prática, uma ação social".

Em seus estudos, Leininger (1988a) postula o cuidado como a essência da enfermagem. Define essência como um constituinte necessário ou atributo essencial que torna uma coisa ou ato naquilo que ele é. Por conseguinte, se a essência é perdida, a coisa ou o ato deixa de ser o que era. Assim, a essência da enfermagem é cuidar e se não houver cuidado, não há enfermagem. Também defende que o cuidado é a essência da saúde, pois é uma necessidade para o desenvolvimento, manutenção da saúde e sobrevivência do ser humano em todas as culturas do mundo.

Segundo Leininger (1988b) "embora a enfermagem utilize a expressão cuidar há mais de um século para definir sua função, não há, dentro da enfermagem, definição da natureza do cuidar que seja adotada ou conhecida por todos as enfermeiras".

Essa autora afirma que o cuidado é a área que oferece "a maior promessa de um corpo de conhecimentos substantivos em enfermagem". Mas "o que o cuidado significa para as enfermeiras e como o cuidado é operacionalizado e usado para ajudar pessoas, permanece um verdadeiro enigma", até porque a "pesquisa sobre o cuidado é bastante recente na enfermagem e apenas uma pequena porcentagem das enfermeiras investiga e promove tal pesquisa" (Leininger, 1988c). Ela define que:

- Cuidar/cuidado refere-se, genericamente, aos atos de assistir, apoiar ou facilitar a um indivíduo ou grupo com necessidades evidentes ou antecipadas, a melhorar uma condição humana ou modo de vida; o termo 
cuidado refere-se, geralmente, aos atributos, ações, e qualidades de assistir outros em suas necessidades.

- Cuidado profissional de enfermagem refere-se à aplicação do conhecimento genérico, mediante o uso de comportamentos, técnicas, processos ou padrões aprendidos cognitiva ou culturalmente (modos humanísticos e científicos), de formas criativas e práticas, para ajuda um indivíduo, família ou comunidade a melhorar ou manter uma condição ou modo de vida saudável, ou para apoiar práticas de cuidado de saúde. Cuidado profissional personifica os objetivos, processos e ações deliberadas e cognitivas dos profissionais prestando assistência a outros, e expressando atitudes e ações de preocupação para com eles, de forma a promover seu bem-estar, aliviar desconfortos, e satisfazer necessidades percebidas ou antecipadas. Cuidado profissional de enfermagem inclui ênfase no cuidado personalizado numa visão holística de saúde e doença dos indivíduos, famílias ou grupos comunitários.

Várias investigações, na área de enfermagem, vêm contribuindo para o aprofundamento da compreensão conceitual sobre o cuidado/cuidar e, cada vez mais, o cuidado vem se caracterizando como atitude e ação.

Para Waldow (1995), cuidar significa "comportamentos e ações que envolvem conhecimentos, valores, habilidades e atitudes, empreendidas no sentido de favorecer as potencialidades das pessoas para manter ou melhorar a condição humana no processo de viver e de morrer". Ainda,

"os estudos e discussões sobre o cuidado humano, como uma característica única e essencial da prática de enfermagem, têm se expandido gradativamente". Ainda assim, é necessário e importante estudar o "processo e fenômeno de cuidar/cuidado na cultura brasileira, pois (...) suas particularidades e a realidade da prática profissional no Brasil merecem ser exploradas para o avanço da profissão, de forma independente e original". (Waldow, 1995)

"Apesar de seu uso freqüente e de sua reconhecida indissociabilidade com a prática de enfermagem, pouco, na verdade, tem sido estudado a respeito do cuidado como fenômeno. (...) Existem muitas controvérsias ao considerar o cuidado como objeto, foco central, essência ou imperativo moral da enfermagem. (...) O cuidar compreende comportamentos e ações que envolvem conhecimentos, valores, habilidades e atitudes, empreendidas no sentido de favorecer as potencialidades das pessoas para manter ou melhorar a condição humana no processo de viver ou morrer. Como cuidado, entende-se o fenômeno resultante do processo de cuidar. (...) 0 cuidar envolve uma ação interativa. Essa ação e o comportamento estão calcados em valores e no conhecimento do ser que cuida para e com o ser que é 
cuidado, e que passa a ser também cuidador. (...) O cuidado humano é imprescindível, tanto como uma forma de viver como de se relacionar". (Waldow, 1997)

Para Phillips (1993), o cuidado é "um processo interativo que exige responsividade do cuidador às necessidades da pessoa cuidada, aos recursos disponíveis e ao contexto no qual o cuidado ocorre. Isso envolve avaliação habilidosa, planejamento, intervenção e avaliação das implicações e detalhes de todos os fatores".

Patrício (1993) também define o cuidado como a essência da enfermagem. Isso quer dizer que, ainda que a profissão enfermagem se transforme "acompanhando os processos naturais/sociais através da história", sua essência não se modifica. Assim, "a enfermagem enquanto profissão existe porque o homem precisa de cuidados de saúde". Para a autora, o que "precisa ser repensado, modificado, é o objetivo, a finalidade do cuidado e o processo de cuidar (a forma como se cuida, como se interage com o cliente e o que ele, cliente, realmente espera de nós), no sentido de acompanhar a realidade em constante transformação."

Henderson (1989) define como função da enfermeira assistir ao indivíduo

"doente ou sadio, no desempenho de atividades que contribuem para manter a saúde ou para recuperá-la (ou ter uma morte serena) - atividades que ele desempenharia só, se tivesse a força, vontade ou o conhecimento necessários. $E$ fazê-lo de modo que o ajude a ganhar sua independência o mais rápido possível".

Para a autora, os cuidados básicos de enfermagem, assim como todos os serviços destinados à promoção do bem-estar social, podem ser fundamentados nas necessidades do ser humano. Então, o profissional precisa estar apto a avaliar o indivíduo quanto a suas necessidades imediatas e em longo prazo nas dimensões física, emocional e social.

Henderson (1989) acrescenta ainda que, embora toda a humanidade sinta as mesmas necessidades, sua satisfação depende de uma infinidade de valores, sem analogia entre si. A percepção do cuidador acerca de si mesmo (em sua capacidade de reconhecer e solucionar seus próprios problemas, no reconhecimento de seus predicados e responsabilidades) influi na capacidade de desempenhar sua função. 
Arruda e Zagonel (1997) preconizam que:

"A enfermagem, vista como disciplina científica, como ciência e arte, e como uma profissão a serviço da humanidade, tem o compromisso de contribuir para 0 aprimoramento das condições de viver e ser saudável aí-no-mundo. A concretização desse sonho pode ser facilitada pelo desenvolvimento de uma consciência de cuidado. Consciência esta que faz parte de todas as áreas de atividade da enfermagem, seja na prática, no ensino, na administração, na teorização, na pesquisa".

Estudos realizados junto a profissionais da enfermagem confirmam essa visão do cuidado como fortemente marcado pelo âmbito relacional. A exemplo, Neves-Arruda, Bittencourt e Gonçalves (1996) investigaram os atributos profissionais de cuidadores de pessoas com câncer, segundo a perspectiva de enfermeiras, e encontraram uma série de atributos que foram categorizados em ser humano, possuir conhecimento técnico-científico, ser responsável, ter self integrado.

Atualmente, seguindo os passos de Madeleine Leininger, estudiosas da enfermagem vêm investigando o significado do cuidado para a clientela dos serviços de saúde.

Gonzaga e Neves-Arruda (1998) verificaram, num hospital pediátrico, que "estar presente e ser fonte de cuidado significa incluir o cuidado emocional/psicológico em todo o processo de cuidar, juntamente com a realização de procedimentos técnicos". No estudo de Costenaro et al (1998), com acompanhantes de crianças e adolescentes hospitalizados, as autoras encontraram como significado de cuidado o sentido de atendimento, atenção por pessoal "bacana", que proporciona alimentação, higiene e orientação. Ribeiro, Koerich e Neves-Arruda (1997) constataram, junto a crianças de 8 a 14 anos hospitalizadas, que o cuidar profissional (do profissional de saúde) é fazer passar a dor, ajudar a melhorar para poder ir para casa, estar preocupado em fazer os clientes se sentirem melhor e dar remédios.

Milton Mayeroff é um filósofo cuja obra sobre o cuidado vem sendo utilizada nos estudos de enfermagem sobre esse tema. Na visão desse autor, "cuidar de outra pessoa, no sentido mais significativo, é ajudá-la a crescer e realizar-se (...); é um processo, uma forma de relação com o outro que envolve desenvolvimento. (...) No contexto da vida de um homem, cuidado é uma maneira de ordenar seus outros valores e atividades que o cercam (...). 
Mediante o cuidado do outro, servindo pelo cuidado, o homem vive o significado de sua própria vida" (Mayeroff, 1971).

Boff (1999) apresenta a filologia da palavra cuidado, apontando que ela evoluiu de um sentido originário desdobrando-se em outras significações afins. Assim, cuidado aparece em alguns dicionários de filologia como termo derivado do latim cura, que era usada num contexto de amor e de amizade para expressar uma "atitude de cuidado, de desvelo, de preocupação e de inquietação pela pessoa amada ou por um objeto de estimação". Em outros, como derivado de cogitare-cogitatus, que tem o mesmo sentido de cura: "cogitar, pensar, colocar atenção, mostrar interesse, revelar uma atitude de desvelo e de preocupação".

Para Boff (1999), cuidado é uma "atitude fundamental, um modo de ser mediante o qual a pessoa sai de si e centra-se no outro com desvelo e solicitude". O autor segue dizendo que "a atitude de cuidado pode provocar preocupação, inquietação e sentido de responsabilidade", o que confere à pessoa que tem cuidado sentimento de envolvimento e ligação afetiva com o outro.

A análise de Merhy (1997) aponta a crise das relações humanas no processo de trabalho em saúde como resultado da perda da dimensão cuidadora nas ações do trabalhador de saúde. Conforme o autor, o modelo assistencial vigente está centrado nos procedimentos, na doença, em detrimento de uma atenção centrada no usuário. Atribui ao modelo procedimento-centrado, a incapacidade de atender as necessidades e direitos dos usuários que "sentem-se inseguros, desinformados, desamparados, desprotegidos, desrespeitados, desprezados".

Ele defende o equilíbrio entre a utilização da tecnologia dos equipamentos, exames e procedimentos, da tecnologia do saber-fazer profissional e da tecnologia da relação interpessoal como o meio para transformar o modelo assistencial para um modelo centrado no usuário e na defesa radical da vida. A tecnologia da relação é o "trabalho vivo (...) que produz um compromisso permanente com a tarefa de acolher, responsabilizar, resolver, autonomizar". Nessas ações, os profissionais operacionalizam o cuidado. Para Merhy (1997), o modo de operar o cuidado em saúde é que deve 
ser o referencial para a construção de um modelo assistencial com mais qualidade.

Tais visões superam a idéia tecnicista de cuidado, muito freqüente em nosso meio, na qual o foco da atenção é o corpo do paciente. Por semelhança, essas visões são os pontos de partida para essa discussão.

\section{Sobre o cuidado da criança na creche}

O cuidado à criança sofreu intensas mudanças, na medida em que o próprio conceito de criança e as condições de vida e de trabalho das populações foram sendo modificados pela história humana, bem como foram sendo desenvolvidas diferentes políticas públicas acerca do atendimento infantil. As mudanças se associam intimamente "às transformações econômicas e sociais que ocorreram nas várias sociedades e, em particular, na família" (Rosseti-Ferreira, Amorim e Vitória, 1994). Ao lado disso, o cuidado também sofreu influências das descobertas da psicologia e pedagogia modernas, em relação aos processos de desenvolvimento e aprendizagem infantis. Assim, o cuidado oferecido às crianças nas instituições do tipo creche também mudou.

As creches surgiram na Europa, primeiro na França, no século XVIII e no Brasil no século XIX, em um contexto em que as instituições asilares eram a referência para entidades de atendimento à população (Merisse, 1997). Nesse contexto, e tendo como objetivo "livrar bebês e crianças pequenas da morte, através de fornecimento de abrigo, alimentação e algum atendimento em higiene e saúde, tendo em vista que suas famílias de trabalhadores não podiam proporcionar-Ihes esses cuidados básicos", fundam-se as creches de cunho caritativo e assistencialista (Merisse, 1997).

Kuhlmann Jr (1991) analisou o processo de constituição das instituições pré-escolares no Brasil, durante a Primeira República. Em seu estudo, questiona as análises correntes na literatura que caracterizam as creches de forma polarizada, afirmando que estas foram, num primeiro momento, médicohigienistas, passando a assistenciais e, atualmente, a educacionais. Seu 
questionamento baseia-se na assunção de que todas as modalidades de atendimentos contêm um aspecto educacional implícito.

Vale lembrar que creches com diferentes objetivos (portanto organizadas de modos absolutamente diversos) são uma constante até os dias de hoje. Há creches nas quais se enfatiza fortemente a disciplina e a obediência e outras em que o foco, ou um deles, é a autonomia da criança.

Por isso, é de grande valor nos determos em alguns pontos historicamente analisados para compreendermos melhor as creches atuais.

Kuhlmann Jr (1991) aponta eventos importantes relativos às instituições pré-escolares, relacionados ao surgimento e percurso da creche no Brasil. Inicia pelo jornal $A$ mãi de familia, lançado em janeiro de 1879 , no Rio de Janeiro, onde aparece uma das primeiras referências à creche: o Dr. K. Vinelli, médico dos expostos da Santa Casa de Misericórdia do Rio de Janeiro, publicou um artigo em partes intitulado "A creche (asilo para a primeira infância)". Em seu artigo, Vinelli expõe que, na França e nos países europeus, a creche foi proposta em função do trabalho feminino nas indústrias, enquanto que no Brasil foi criada mais para atender às mães trabalhadoras domésticas.

Nesse mesmo período, também se desenvolve o setor privado da educação pré-escolar, voltado para as elites. Os chamados "jardins de infância" são propagandeados como tendo causas "essencialmente distintas" das creches/asilos destinadas às classes populares, uma vez que tinham um caráter "pedagógico" (Bandeira Filho apud Kuhlmann Jr, 1991).

Esse processo de instituição das creches determinou que até hoje a creche ainda seja vista, em muitos meios, como serviço para as crianças pobres com qualidade de atendimento precária. Por outro lado, para as populações de maior poder aquisitivo costuma-se diferenciar as instituições de atendimento infantil chamando-as de jardim de infância, escolinha ou berçário.

Esse autor ressalta um aspecto muito importante, referente à controvérsia acerca da proposta de constituição das creches, uma vez que traz à tona "conflitos com a defesa do papel materno, tanto sob o aspecto médico (defesa da amamentação) quanto no aspecto jurídico (abandono de menores)". 
Assim, desde seu surgimento, os mais diversos autores questionaram a função da creche, apontando-a não apenas como uma necessidade mas como um "mal necessário".

$\mathrm{Na}$ época em que as creches começaram a expandir-se em São Paulo, Costa $^{1}$ (1984) publicou um artigo acerca dos efeitos (negativos) que a institucionalização precoce da criança nesses locais traria sobre 0 desenvolvimento infantil, destacando a necessidade de serem realizados estudos relativos à avaliação do desempenho das creches e do perfil das crianças que foram aí educadas.

Rosseti-Ferreira (1984) aponta que há muita divergência de opiniões a respeito das vantagens e desvantagens das diferentes formas de cuidado à criança (o materno exclusivamente, em creches, com babás) e que ainda há poucos estudos que podem oferecer uma maior clareza acerca do tema.

Essa autora realizou uma extensa revisão bibliográfica sobre o apego e as reações da criança à separação da mãe e concluiu que os estudos clássicos, freqüentemente referenciados, pouco podem contribuir para uma "discussão sobre as condições mínimas necessárias para garantir o desenvolvimento 'normal' da criança", devido à limitações tais como: a "artificialidade das situações de separação observadas, a ênfase demasiada na figura da mãe e a ausência de outras pessoas para interagir com a criança durante o procedimento experimental de separação e reunião". Por outro lado, verificou estudos mais recentes indicando que "um cuidado alternativo e estável e de boa qualidade não interfere na ligação afetiva com a mãe e nem prejudica seu desenvolvimento", embora estes tenham sido realizados em creches com alto padrão de qualidade, nas quais os educadores tinham um pequeno número de crianças para cuidar. Sabemos que, tão importante quanto o número de crianças a cargo de cada adulto, é o preparo do adulto para essa tarefa.

Continuando com sua análise, Kuhlmann Jr (1991) lembra que, na época do surgimento das creches, estas "não eram apenas um mal necessário, mas

\footnotetext{
${ }^{1}$ Médico. Pediatra de uma grande creche da cidade de São Paulo.
} 
representavam a sustentação dos saberes jurídico, médico e religioso no controle da política assistencial que se elaborava".

Assim, do ponto de vista médico-higienista, as propostas fundamentavam-se na preocupação com a mortalidade infantil, importante em uma época de fortalecimento das nacionalidades. Nesse contexto, Arthur Moncorvo Filho fundou o Instituto de Proteção e Assistência à Infância que, num período de trinta anos, entre o ocaso do século XIX e início do XX, contava com 22 filiais em todo o país. Esse instituto tinha como objetivos:

"inspecionar e regulamentar a lactação, inspecionar as condições de vida das crianças pobres (alimentação, roupas, habitação, educação, instrução); dispensar proteção às crianças abandonadas; auxiliar inspeção médica nas escolas e indústrias; zelar pela vacinação; difundir meios de combate à tuberculose e outras doenças comuns às crianças; (...) manter o dispensário Moncorvo para tratamento das crianças pobres; criar um hospital para crianças pobres; auxiliar os poderes públicos na proteção às crianças necessitadas". (Kuhlmann Jr, 1991)

Segundo Merisse (1997), o Instituto de Proteção e Assistência à Infância

"foi o irradiador, em nosso país, do que ficou conhecido como assistência científica, um conjunto de concepções resultante da união entre a ciência e a ordem capitalista internacional. Essas concepções, além de se apropriarem da ideologia do progresso permanente, consideravam que o Estado deveria, através da ciência, controlar as instituições, para que estas ordenassem a vida e a reprodução das classes populares".

Assim, como explica Kuhlmann Jr (1991), "do ponto de vista da influência jurídico-policial, as preocupações com as legislações trabalhista e criminal apontavam o tema da chamada infância moralmente abandonada." $O$ foco era criar um novo tipo de atendimento à infância, visando evitar a criminalidade à qual atribuía-se a hereditariedade, e a fatores sociais, dando-se relevo à desorganização familiar. Esse ponto de vista era justificado pela antropologia e sociologia criminal. Os pais eram caracterizados como "socialmente imprestáveis, negligentes, incapazes ou indignos. Aos incapazes (que necessitam de melhores condições de vida, habitação, etc), mas honestos, dever-se-ia ajudar criando creches, salas de asilo e escolas maternais".

Algumas instituições assistencialistas caracterizaram-se por ênfase no aspecto educativo. Este, contudo, fundava-se no "apostolado da instrução e da saúde" e evidenciava ter como função evitar a luta de classes mediante "o 
rígido controle dos demandatários" dessas instituições, com "inquéritos minuciosos sobre suas vidas particulares" reforçando que a educação infantil, tal como outros benefícios, era um mérito daqueles que se tornassem mais subservientes e não um direito do trabalhador. (Kuhlmann Jr, 1991)

O autor expõe que os objetivos da educação assistencialista eram isolar as crianças dos meios perniciosos, como a rua, e oferecer uma educação de baixa qualidade, pois as crianças pobres deveriam ser preparadas para o futuro que Ihes era destinado, de maneira resignada, a uma posição social de submissão.

Pode-se supor também que a questão do cuidado na creche era caracterizada como uma compensação por aquilo que faltava à criança em sua casa, mas que podia ser de baixa qualidade tal como a educação que recebiam, pois 0 atendimento das crianças nessa instituição não podia perder de vista "o meio em que terão que viver" (Kuhlmann Jr, 1991).

Dessa forma, a necessidade política e o discurso científico ajudaram a construir e justificar a implementação desses serviços com as características descritas.

Atualmente, esse modelo assistencialista e higienista tem sido muito criticado e combatido, tanto no discurso quanto na realidade, com a implementação de propostas inovadoras, embora não seja possível afirmar que em todas as instituições isso tenha ocorrido. Entretanto, ao buscar superar esses modelos, pode-se cair num extremo oposto que precisa ser avaliado quanto à sua adequação.

Um estudo realizado por uma enfermeira, que abordou especificamente o cuidado, aponta essa questão. Maranhão (1998) afirma que

"a crítica ao modelo higienista, embora tenha contribuído para um grande avanço em relação às leis e aos programas no tocante à educação infantil, criou alguns equívocos em torno dos necessários cuidados com a saúde. Assim, em determinado momento desse processo de transformação institucional, todo e qualquer cuidado com a saúde passou a ser interpretado como resquício da concepção higienista ou, então, como de exclusiva competência dos serviços de saúde, o que quer dizer, desnecessário de ser planejado e operacionalizado no interior da creche".

Essa autora justifica a necessidade de se revalorizar o cuidado pois 
"se a concepção de saúde for a de que se trata de um fenômeno construído no dia a dia, no modo como se vive e organiza o cotidiano, na forma de interação com o ambiente físico e social, então, a forma como se organiza e operacionaliza o cuidado com as crianças, nas creches e préescolas, seria o principal objeto de atenção dos profissionais de saúde e não apenas alguns procedimentos específicos em torno dos chamados riscos físicos, químicos e biológicos".

A crítica ao modelo assistencialista tem sido feita mediante ênfase à missão educativa da creche. Sob a justificativa de que a missão da creche ou pré-escola é educar, muitas instituições têm organizado sua programação em torno de atividades pedagógicas exclusivamente, dando tarefas para a casa e afirmando que lugar de brincar é em casa, não na escola. Nesse caminho, temse negligenciado um aprofundamento sobre o cuidado.

Parece que qualquer uma dessas visões, ao rejeitarem uma ou outra função da creche, termina por incorrer num reducionismo que culmina na atenção parcializada à criança. Além disso, perde a possibilidade de utilizar as contribuições das diferentes disciplinas para a construção de um atendimento integrado e global à criança.

\section{O Referencial Curricular Nacional para a Educação Infantil e o cuidado}

Uma fonte bastante atual para a discussão sobre 0 atendimento das crianças na creche é o Referencial Curricular Nacional para a Educação Infantil (Ministério, 1998). Elaborado com a participação de um grande número de especialistas de todo o país, sob a égide do Ministério da Educação e do Desporto, teve sua publicação definitiva em 1998 e deverá constituir-se em fonte importante para os projetos das creches Brasileiras.

A necessidade que gerou a elaboração do referencial foi a Lei de Diretrizes e Bases da Educação Nacional (Lei 9.349/96) que estabeleceu a educação infantil como a primeira etapa da educação básica.

$\mathrm{Na}$ apresentação do documento, o Ministro da Educação, Paulo Renato de Souza, enfatiza que o Referencial "pretende apontar metas de qualidade que contribuam para que as crianças tenham um desenvolvimento integral de suas identidades, capazes de crescerem como cidadãos cujos direitos à infância são reconhecidos". Continua, afirmando que este "representa um 
avanço na educação infantil ao buscar soluções educativas para a superação, de um lado, da tradição assistencialista das creches e, de outro, da marca da antecipação da escolaridade das pré-escolas". (Ministério, 1998a)

Evidencia-se que é um propósito do referencial oferecer subsídios para superar a dicotomia que tem marcado os projetos para o atendimento infantil nessas instituições. Tal superação consistiria na incorporação dos cuidados essenciais das crianças e suas brincadeiras às atividades educativas. Este é o desafio atual das creches e pré-escolas, afirma o Ministro. (Ministério,1998a)

Assim, coloca-se o cuidar ou as ações de cuidado como um componente da atenção à criança na creche e na pré-escola, intrinsecamente ligados à educação, contrapondo-se ao discurso histórico sobre as funções da creche que, muitas vezes, dissociou esses componentes, ora destacando-se 0 cuidado, ora enfatizando o papel educativo do serviço.

Na caracterização do Referencial, são expostos os princípios que devem fundamentar a qualidade das experiências oferecidas às crianças nesse contexto. Dentre eles, "o atendimento aos cuidados essenciais associados à sobrevivência e ao desenvolvimento de sua identidade". Pode-se dizer que, se são essenciais, todas as crianças os necessitam e estes não devem ser negligenciados, desvalorizados nem postergados.

Define educar como "propiciar situações de cuidados, brincadeiras e aprendizagens orientadas de forma integrada e que possam contribuir para 0 desenvolvimento das capacidades infantis de relação interpessoal, de ser e estar com os outros em uma atitude básica de aceitação, respeito e confiança, e o acesso, pelas crianças, aos conhecimentos mais amplos da realidade social e cultural". (Ministério, 1998a). Assim, relaciona claramente que a forma de cuidar deve ser educativa.

Define cuidar na esfera da educação infantil "como parte integrante da educação, embora possa exigir conhecimentos, habilidades e instrumentos que extrapolam a dimensão pedagógica (...) demandando a integração de vários campos de conhecimento e a cooperação de profissionais de diferentes áreas". (Brasil,1998a). 
Aqui, começa-se a delinear a noção de que cuidar não é algo que se realiza empiricamente, destituído de princípios orientadores estabelecidos segundo as metas da atenção à criança na creche. A maneira como a criança é cuidada, pode favorecer ou não o desenvolvimento de suas capacidades. Mais que isso, pode-se dizer que as situações de brincadeira e aprendizagem conformam-se também como momentos em que a criança pode estar sendo cuidada ou não. Ao mesmo tempo, aponta a mútua dependência entre cuidar e educar.

Ao tratar do perfil profissional da professora da creche, o Referencial destaca a necessidade de que esta seja polivalente, trabalhando "conteúdos de naturezas diversas que abrangem desde cuidados básicos essenciais até conhecimentos específicos provenientes das diversas áreas do conhecimento". Assim, a professora precisa ser capacitada para a construção de projetos educativos junto aos familiares e às crianças e, para isso, "é preciso que as professoras estejam comprometidas com a prática educacional, capazes de responder às demandas familiares e das crianças, assim como às questões específicas relativas ao cuidado e aprendizagem infantis" (Ministério, 1998a).

Neste ponto, reforça a necessidade de formação específica para 0 cuidar, enquanto conteúdos ou conhecimentos compatíveis com as demandas da criança.

A organização do tempo é uma das questões apresentadas no tema orientações didáticas. Nesse sentido, a rotina que estrutura o tempo de trabalho junto às crianças "deve envolver os cuidados, as brincadeiras e as situações de aprendizagem orientadas". Outro item deste tema constitui as atividades permanentes, tidas como as que "respondem às necessidades básicas de cuidados, aprendizagem e de prazer para as crianças, cujos conteúdos necessitam de uma constância", dentre as quais inclui-se “cuidados com o corpo" (Ministério, 1998a). Pode-se dizer que, ainda que nessa abordagem de cuidado enquanto atividades ligadas ao corpo, o cuidado evidenciado como atividade permanente é essencial e indissociável do cotidiano da criança na creche.

Outro ponto de destaque é a visão de cuidar na creche como um direito fundamental de todas as crianças e não uma benemerência destinada às 
crianças desamparadas. Ao caracterizar o cuidado como atividade permanente e essencial na creche, o Referencial firma o cuidado como um dos componentes da proposta curricular (Ministério, 1998a). Isso confronta-se com a visão tradicional de que o cuidado na creche se dá em substituição ou compensação pela deficiência de cuidados oferecidos pela família. Pode-se acrescentar, ainda, que as necessidades básicas que podem ser atendidas mediante o cuidar são inerentes a todo ser humano e, portanto, a criança também precisa ser cuidada na creche e isso independe da qualidade do cuidado que ela recebe em casa.

Ao abordar especificamente o tema do cuidado da criança na creche, o Referencial aponta que "a instituição necessita criar um ambiente de cuidado que considere as necessidades das diferentes faixas etárias, das famílias e das condições de atendimento da instituição". E uma vez que "as atividades de cuidado das crianças se organizam em função de suas necessidades nas 24 horas do dia", deve haver "uma programação conjunta com as famílias para divisão de responsabilidades, evitando-se a sobreposição ou a ausência de alguns cuidados essenciais". Assim, é necessário conhecer a criança e suas peculiaridades, tais como "esquemas, preferências e intolerância alimentar, hábitos de sono e de eliminação, controles e cuidados especiais com sua saúde", a fim de poder planejar os cuidados e a vida cotidiana na creche. (Ministério, 1998a). São requisitos que permitem delinear o cuidado individualizado, significando que, embora haja a dimensão coletiva da atenção às crianças nesse contexto, cuidar também demanda 0 atendimento de necessidades individuais.

Ao tratar sobre os primeiros dias da criança na creche, o chamado período de adaptação à nova situação, aponta vários cuidados que podem favorecer esse processo, cuidados esses referentes principalmente à criança, mas também à mãe ou acompanhante e à própria professora. (Ministério, 1998a).

"A capacidade das crianças de terem confiança em si próprias e o fato de sentirem-se aceitas, ouvidas, cuidadas e amadas oferecem segurança para sua formação pessoal e social", para o desenvolvimento de sua identidade e conquista da autonomia (Ministério, 1998b). Além disso, mediante o cuidado, a 
interação e a brincadeira, estabelecem-se vínculos afetivos significativos entre a criança e as pessoas que cuidam dela. Nessas afirmações, começam a delinear-se outras funções do cuidar que não apenas a manutenção do corpo. Este é um avanço importante, uma vez que, muitas vezes, essa visão restrita de cuidar como atividades relacionadas ao corpo somente é que fundamenta as ações entendidas como de promoção à saúde.

Outro aspecto é o poder educativo das ações de cuidado. A forma como o cuidado pessoal é oferecido, o exemplo dos adultos, as ações de cuidado com o ambiente, podem favorecer ou não a construção de conhecimentos, atitudes e comportamentos de cuidado de si, do outro e do ambiente. Esse aspecto é enfocado nas orientações didáticas que são trabalhadas nos conteúdos específicos, bem como nas orientações gerais para a professora, apresentadas no volume 2 do Referencial (Ministério, 1998b).

Ao abordar os cuidados pessoais, o Referencial aponta ações importantes relativas à higiene, alimentação e segurança e descreve como realizar algumas ações sob o tema organizando um ambiente de cuidados essenciais (Ministério, 1998b). Nesse tema, é possível identificar a congruência presente no texto, que associa o ambiente de cuidados essenciais àquele que extrapola o aspecto físico-orgânico do cuidar. Isso fica explícito na afirmação "uma criança saudável não é apenas aquela que tem o corpo nutrido e limpo", crença vigente ainda em muitas instituições, "mas aquela que pode utilizar e desenvolver o seu potencial biológico, emocional e cognitivo, próprio da espécie humana, em um dado momento histórico, em uma dada cultura".

Entretanto, a afirmação que o ambiente de cuidado é diferenciado segundo as diferentes idades, diferentes famílias e diferentes condições de atendimento de nutrição, pode gerar uma interpretação empobrecida de cuidado como sinônimo de atividades. Um exemplo sobre a situação da alimentação pode ajudar a esclarecer essa idéia. Crianças oriundas de famílias com diferentes condições sócio-econômicas e até culturais podem necessitar que a creche tenha possibilidade de suprir diferentes porcentagens de nutrientes na alimentação que Ihes é oferecida. Mas toda criança precisa exercitar sua autonomia para alimentar-se, sentir-se respeitada e atendida durante as refeições. Para tanto, as ações de cuidado referem-se mais à 
comunicação verbal e não-verbal da educadora que ao alimento oferecido. Nesse sentido, o ambiente de cuidado propriamente não seria distinto para as diferentes crianças.

O cuidado se expressa nas ações e na forma como estas são realizadas. O grande desafio atualmente refere-se à operacionalização dos princípios do Referencial, pois este, por si só, não é suficiente para mudar a qualidade do cuidado oferecido à criança. E o desafio é ainda maior quando nos remetemos às diferenças de recursos humanos e materiais presentes na realidade da atenção infantil em nosso país. Aliar a teoria à prática, implementando os princípios do Referencial, demanda um processo de trabalho que é determinado pela compreensão e possibilidades daqueles que realizam essa prática.

Concretizar os fundamentos teóricos de cuidar consiste em estabelecer objetivos, ações, conteúdos, formas de interação e o "como fazer" fundamentado em orientações didáticas que articulem as atividades ao universo cultural e desenvolvimento das crianças. Para tanto, o "como fazer" precisa ser mais do que um fazer mecânico, um fazer que impõe à criança uma passividade. Ao invés disso, as ações de cuidado podem ser momentos de descobertas e desafios para a criança.

Nesse sentido, o que o Referencial não explicita, é que existe um forte componente atitudinal que configura as maneiras de educar e de cuidar, mas que deve ser compreendido e explorado, pois essa seria a forma de desenvolver o que é referido no documento como a "sensibilidade da professora".

Enfocando atitude não como um modo de proceder ou agir mas como uma maneira de ser em relação a algo (Ferreira, 1986) temos que a atitude é um componente abstrato, interno à pessoa. Nesse sentido, os comportamentos da professora e as atividades que realiza com as crianças são determinados pela atitude que ela tem em relação à criança, a sua função e à função social da creche.

Partindo dessa premissa, para caracterizar educar e cuidar, devemos nos remeter às interações estabelecidas entre a criança e a professora. Isso 
quer dizer que aquilo que é dito e feito é tão importante quanto o modo como se diz e faz.

Diante do exposto, podemos começar a compor uma definição de cuidar que fundamenta o Referencial, embora este não explicite um marco conceitual de cuidar. Assim, segundo o Referencial, cuidar é basicamente uma resposta a algumas necessidades básicas da criança, ou seja, ações ou atividades que atendem as demandas físicas, tais como higiene, alimentação e segurança. Com menor ênfase, aponta também sua importância para a afetividade, a formação de vínculo entre a criança e o cuidador, que atenderia a demanda da necessidade de segurança emocional, mas não explora esse aspecto. Por exemplo, ao aprofundar aspectos da interação não os relaciona à maneira de cuidar e considerar o cuidado enquanto uma atitude remete à maneira como se dão as interações.

O referencial ainda não espelha a realidade mas aponta diretrizes que deverão balizar essa realidade. Assim, acredito que o momento atual é propício à consecução deste estudo, pois ele poderá contribuir para a concretização dessas diretrizes.

A princípio, percebe-se a necessidade de aprofundar o que se entende por cuidado, considerando o pressuposto que ele pode permear as situações educativas e recreativas, extrapolando as ações de preservação física apenas.

A idéia de superar os enfoques médico-higienista e assistencialista suscita o desafio de construir uma nova visão, um novo referencial de atendimento da criança. É falar de cuidado à criança sadia, e de creche como um direito da criança, como um espaço de vida e saúde, de interações, de descobertas e aprendizagem, de desenvolvimento de suas potencialidades e cidadania. Esse enfoque responde à função de promover saúde à criança usuária do serviço, numa perspectiva de superar a noção de que a creche seja um "mal necessário", um risco ao desenvolvimento infantil.

Considerando a importância do cuidado para o desenvolvimento infantil, conforme apresentado em vários pontos do Referencial, emerge a necessidade de aprofundar a compreensão sobre o cuidar da criança no contexto da creche. 
Acredito que o problema aqui exposto decorre da forma como o cuidado à criança é representado em nosso meio. Assim, se ele é representado como algo de menor valor, restrito a atividades pontuais, que não demandam conhecimentos específicos e que podem ser realizadas por qualquer pessoa de bom senso, pode-se supor que os profissionais da creche também percebam 0 cuidado dessa forma, o que determina a maneira como eles realizam esse cuidado.

Outrossim, à medida que a Lei de Diretrizes e Bases da Educação Nacional define a creche como instituição educativa, se os cuidados não são compreendidos como integrantes do processo educativo, eles podem estar sendo negligenciados ou realizados às custas de insatisfação dos profissionais.

Hoje, podemos dizer que coexistem instituições de atendimento à criança que ainda concebem creche como espaço de guarda de crianças carentes e, de outro lado, instituições que pautam por uma atuação educativa instrucional que pode ser avaliada como um crime de lesa-infância. Entre um extremo e outro, uma ampla variedade de serviços, com suas propostas e estratégias distintas.

É certo que existe uma variação cultural, regional, de recursos, que precisa ser considerada quando da elaboração de qualquer proposta de atendimento à população infantil. Entretanto, buscar definir diretrizes é uma meta importante que pode contribuir para a elaboração de propostas que, considerando tais variações, busquem alternativas para a eqüidade, promovendo cada vez mais o desenvolvimento de cidadãos plenos e integrados. Isso permitiria, por exemplo, a superação da noção de que a atenção à criança desprovida de recursos econômicos pode ser pobre.

Nesse sentido, o debate entre cuidar e educar na creche vem constituindo um eixo fundamental para a definição dessas diretrizes mais amplas. O Referencial Curricular Nacional para a Educação Infantil aponta a questão com uma visão abrangente e atual. Entretanto, nesse documento, a definição de educar está melhor aprofundada do que a definição de cuidar, o que é significativo. Ao lado disso, na prática do atendimento na creche, também se verifica uma visão de menosprezo ao cuidado em função de uma valorização do aspecto educativo, sobrepondo este ao primeiro. Isso ocorre 
particularmente em função de uma compreensão de educação enquanto instrução formal, de sala de aula, e cuidado como ações que não demandam conhecimentos aprimorados.

Assim, considerando a importância do cuidado para o desenvolvimento infantil, conforme apresentado em vários pontos do próprio Referencial, justifica-se a necessidade de aprofundar a compreensão sobre o cuidar da criança no contexto da creche.

\section{Objetivo}

Com base no exposto, são objetivos deste estudo apreender e analisar as representações dos profissionais que atuam na creche, acerca do cuidado da criança.

O alcance desse objetivo tem como finalidade oferecer subsídios para o debate que ora se estabelece, em função das diretrizes curriculares para a educação infantil e assim contribuir para a melhoria da atenção à criança que freqüenta creche. 


\section{Referencial teórico-metodológico}

O referencial teórico-metodológico selecionado para esta investigação foi a Teoria das Representações Sociais, de Moscovici. Esta teoria possibilita a apreensão da dinâmica da formação dos fenômenos de natureza social e psicológica.

A teoria de representação social foi elaborada em 1961, por Serge Moscovici, a partir do conceito sociológico de representação coletiva de Durkheim, transpondo-o para a psicologia social.

A representação social consiste em: imagens que condensam um conjunto de significados; sistemas de referência que nos permitem interpretar o que ocorre conosco e até mesmo dar um sentido ao inesperado; categorias que servem para classificar as circunstâncias, os fenômenos e os indivíduos com os quais nos relacionamos; teorias que permitem estabelecer fatos entre eles; e tudo isso em conjunto. Resumindo, é uma maneira de interpretar e de pensar a realidade cotidiana, uma forma de conhecimento social compartilhado por um grupo (Jodelet, 1986).

A representação social se situa na intersecção do psicológico e do social. Assim, dá-se pela atividade mental dos indivíduos e grupos em relação às situações, acontecimentos, objetos e comunicações que Ihes dizem respeito. E o social intervém na atividade mental através do contexto concreto em que se situam os indivíduos ou grupos, da comunicação que se estabelece entre eles, dos marcos de compreensão que lhes permite sua bagagem cultural e dos códigos, valores e ideologias relacionados com as posições sociais específicas.

Conforme Souza Filho (1993), esta teoria surge da busca de Moscovici para superar a visão comportamental e cognitivista da psicologia social para o estudo de atitudes, opiniões, imagens e estereótipos bem como a perspectiva do determinismo sócio-econômico sobre os fenômenos sócio-simbólicos dos estudos da sociologia sobre ideologia e visão de mundo. Assim, "o campo de estudo da representação social surgiu de uma crítica aos modelos que reduziam a participação do sujeito, tanto na produção autônoma da história, 
quanto da consideração de sua capacidade criativa através de função simbólica complexa".

Caracteriza-se pela maneira como o sujeito apreende sua realidade, compondo um conhecimento espontâneo, ingênuo, chamado de conhecimento de senso comum, ou pensamento natural, que se opõe ao pensamento científico. É um conhecimento socialmente elaborado e compartilhado porque se constrói nas relações do sujeito com a realidade que o cerca, como produto e processo de uma elaboração psicológica e social do real.

É, no entanto, um conhecimento prático, no sentido de que permite a comunicação entre os indivíduos e serve para que eles se posicionem em relação ao mundo, dominando-o.

O conteúdo que define as representações sociais constitui-se de atitudes, imagens, opiniões e informações. Esse conteúdo refere-se a algo (o objeto) e foi elaborado por alguém (o sujeito). Ao representar o objeto, o sujeito o substitui por um símbolo em sua mente ou consciência. Através do pensamento, o objeto é reconstruído na mente sob a forma de um conteúdo concreto, tomando um caráter figurativo e simbólico. O aspecto figurativo (imagem) é inseparável do aspecto simbólico, pois toda imagem está associada a um sentido e vice-versa.

A imagem não é uma cópia, uma simples reprodução do mundo real no interior do indivíduo, posto que, ao apreender a realidade, o indivíduo interpreta-a, atribuindo-Ihe um significado. Portanto, a representação é uma construção de caráter criativo e autônomo.

A atribuição de significados é particular a cada grupo. Isso porque se dá em função da rede de significados criada segundo a hierarquia de valores que se impõe na sociedade e em seus diferentes grupos, sendo o objeto situado e avaliado em relação a essa rede.

Há dois processos principais que explicam a construção das representações sociais. São eles: a ancoragem e a objetivação (Jodelet, 1986).

A objetivação é uma operação formadora de imagem e estruturante. A representação permite intercambiar percepção e conceito, tornando concreto aquilo que é abstrato, ou seja, o conhecimento acerca do objeto. 
A objetivação desenvolve-se em três etapas: seleção $e$ descontextualização dos elementos, formação de um núcleo figurativo e naturalização. Assim, as informações acerca de um objeto sofrem uma seleção em função de critérios culturais (segundo o acesso dos indivíduos às informações) e normativos (referente ao sistema de valores, posições sociais e interesses dos indivíduos).

A partir da seleção, pode-se coordenar os elementos, formando um núcleo figurativo, que é uma estrutura de imagem que reproduz a estrutura conceitual. E a naturalização é a transformação dos elementos figurativos e abstratos em elementos da realidade.

O segundo processo para a construção da representação, a ancoragem, é o processo de assimilação de novas informações a um conteúdo cognitivoemocional pré-existente. Ao integrar o conhecimento construído acerca do objeto, no sistema de pensamento social, este passa a ter utilidade e significado.

A ancoragem compreende três aspectos: a atribuição de significado ao objeto, um sistema de interpretação do mundo social e instrumento da conduta dos indivíduos e o enraizamento da representação no sistema de pensamento.

Ao serem utilizadas como sistema de interpretação do mundo social e instrumento de conduta dos homens, as representações sociais exercem uma função mediadora entre o indivíduo e o grupo, oferecendo ao primeiro um sistema de classificação comum ao grupo, o qual the serve como referência para avaliar os outros. Desta maneira, a ancoragem garante a relação entre a função cognitiva da representação e sua função social e, assim, torna possível o enraizamento social do objeto representado.

No caso do cuidado da criança, torna-se uma opção adequada pois trata-se de um fenômeno presente em toda a história da humanidade, que foi sendo reinterpretado tanto à luz da ciência quanto do conhecimento do senso comum. Assim, a seleção desta teoria é vantajosa para este estudo pois permite apreender e analisar a maneira como as profissionais da creche apreendem o cuidado, como o representam e, em decorrência disto, orientam suas ações. 
Quer se compare épocas diversas, quer se tenha em mente apenas o momento atual, vê-se a existência de diferentes concepções de criança e, consequentemente, de seu cuidado.

Há valiosos estudos históricos a esse respeito: Ariès (1981) e Badinter (1985) com ensaios balisados em documentos europeus; Freyre (1978) e Marcílio (2000) iluminando os acontecimentos no Brasil. Outros, debruçados sobre a questão da criança em instituições que foram as precursoras das creches brasileiras, também nos esclarecem: Kuhlmann Jr (1991), Merisse (1997) e, novamente, de modo indireto, Marcílio (2000).

Em qualquer das épocas estudadas, inclusive atualmente, vê-se a pluralidade de representações a respeito do tema. Se o Referencial entende que a creche é uma instituição de educação e cuidado, primordialmente centrada nas necessidades da criança, a Prefeitura do Município de São Paulo ainda se pauta pela concepção de creche como equipamento de guarda.

Assim, torna-se de grande valor captar como profissionais de creche que consideramos como luminares no Brasil vêem o tema.

Enquanto metodologia de investigação, a representação social permite desenvolver estudos descritivos populacionais, analisados estatisticamente, e também estudos individuais dinâmicos (Lane, 1993). Em consonância com o problema e o objetivo anteriormente expostos, o método qualitativo é o mais apropriado ao desenvolvimento da presente investigação.

O método qualitativo de pesquisa é uma abordagem sistemática, subjetiva, usada para descrever experiências de vida e seus significados. Origina-se no paradigma humanista que compreende o mundo como dinâmico e em transformação.

Segundo Demo (2000), a pesquisa qualitativa faz jus à complexidade da realidade, curvando-se diante dela, não o contrário, como ocorre com a ditadura do método ou a demissão teórica que imagina dados evidentes.

As metodologias de pesquisa qualitativa são "capazes de incorporar a questão do SIGNIFICADO e da INTENCIONALIDADE como inerentes aos atos, às relações e às estruturas sociais" (Minayo, 1993). 
Conforme Souza Filho (1993), os métodos de análise de conteúdo e de discurso respondem à tarefa básica de um estudo de representação social, que é "explicitar elementos de sentido isolados ou combinados em construtos representacionais, produzidos, mantidos e extintos em função de condições sociais específicas, vividas por indivíduos e grupos".

\section{Cenário do estudo}

O estudo foi realizado junto às creches da Universidade de São Paulo (USP), situadas no município de São Paulo e administradas pela Coordenadoria de Assistência Social (Coseas). A Coseas é um órgão da USP ligado diretamente à Reitoria e encarregado de implementar a política de atendimento social a funcionários e estudantes. A Divisão de Creches da Coseas conta com três unidades no município de São Paulo (a Central, a da Saúde e a Oeste), além de uma unidade localizada no município de Ribeirão Preto (a Carochinha), atendendo, no total, 540 crianças (Universidade, 1999).

A Creche Central é a maior das unidades. Inaugurada em 1982, situa-se no campus da Cidade Universitária e atende 245 crianças. A Creche Oeste foi inaugurada em 1990, também se localiza no campus da Cidade Universitária e atende em torno de 110 crianças. A Creche da Saúde localiza-se no campus Pinheiros e tem um total de 45 vagas.

Os usuários das creches são funcionários docentes e técnicoadministrativos, bem como discentes vinculados à universidade. Em virtude da demanda ser muito maior do que o número de vagas, a entrada das crianças ocorre mediante processo seletivo.

A Divisão de Creches é coordenada por uma Diretora Técnica. As equipes técnicas das Creches Central e Oeste são compostas por uma diretora, uma pedagoga e uma psicóloga; a Creche Saúde tem apenas uma profissional no papel de diretora e coordenadora pedagógica. As creches maiores contam ainda com coordenadores de módulos, que supervisionam mais diretamente o trabalho das educadoras (Universidade, 1999). As educadoras são as trabalhadoras que atendem diretamente as crianças. As creches contam, ainda, com o acompanhamento de uma médica pediatra, 
lotada na Divisão, além de auxiliares de enfermagem 17 , técnica em nutrição ou nutricionista ${ }^{1}$, pessoal de limpeza e serviços gerais.

Uma característica comum a essas creches é que, por sua vinculação à universidade, costumam receber outros profissionais e estudantes de graduação de diversos cursos da USP, seja para o desenvolvimento de projetos específicos seja para estágios.

As creches atendem em período integral, de segunda a sexta-feira, com algumas variações de horários de entrada e saída, rotinas e propostas de atividades, segundo as características da população usuária, dos trabalhadores das unidades e da própria coordenação de cada unidade. Entretanto, seguem uma diretriz pedagógica comum, compartilham e atualizam as propostas de atividades nos encontros das creches, realizados anualmente.

Vale destacar que, tal como aconteceu na sociedade brasileira, a origem desse serviço assenta-se nos movimentos de trabalhadores e discentes da universidade, iniciados em 1965 (Conselho, 1988). Na USP, a organização do serviço de creche iniciou-se em 1980, com a contratação de uma equipe de especialistas pela Coseas, que elaborou um projeto, em conjunto com entidades representativas da comunidade uspiana.

Pode-se afirmar que, no universo das creches existentes em nosso meio, as creches da USP são instituições de qualidade destacada, tendo já superado problemas que ainda são comuns em grande parte das instituições. Por isso, constituem um local privilegiado para aprofundamento do objeto de estudo.

A opção por esse cenário de investigação teve a pretensão de, partindo de uma prática já diferenciada no que tange a uma importante parcela das creches existentes, contribuir para o debate acerca dos princípios e diretrizes para os projetos de atendimento das instituições de educação infantil.

A esse respeito, Wilheim (1991) afirma:

"As creches nas universidades são excelentes experiências que reúnem teoria e prática, reunião essa muito necessária para 0 aprofundamento científico do atendimento, principalmente no que diz respeito aos aspectos educacionais. Os

\footnotetext{
${ }^{1}$ À exceção da Creche Saúde que conta com um quadro mais reduzido de pessoal, em função de seu menor tamanho.
} 
núcleos de creches nas universidades têm funcionado também como escolas de formação profissional para os educadores. (...) são as creches de universidades que permitem inovações".

\section{Inserção da pesquisadora na realidade das creches}

Visando definir o problema e os objetivos do estudo, iniciei, em 1999, um processo de aproximação junto à coordenadora da Divisão de Creches da Coseas, tendo como ponto de partida a solicitação de autorização para realizar visitas de observação nas creches.

Após a permissão, estabeleci, juntamente com as coordenadoras das creches, um calendário de visitas e de atividades que eu poderia acompanhar para conhecer o funcionamento dos serviços e as equipes de trabalho. A primeira creche que visitei foi a Oeste. Durante cerca de 3 meses, estive presente de uma a duas vezes por semana, tendo me inserido num grupo de estudo e acompanhado atividades das crianças com as educadoras ou com as auxiliares de enfermagem. A seguir, na creche Central, realizei um número menor de visitas, as quais centraram-se em acompanhar algumas atividades das educadoras com as crianças.

Realizei, ainda, entrevistas informais com algumas coordenadoras, com a Diretora da Divisão, com uma auxiliar de enfermagem e com a pediatra. Essas conversas foram registradas em um diário, assim como todas as visitas e reuniões de estudo. Ao final desses encontros, havia organizado elementos suficientes para o delineamento do problema e objetivo do estudo.

\section{População}

A população foi constituída por nove educadoras e sete coordenadoras (sendo seis componentes das equipes técnicas e uma coordenadora de módulo) das creches. A opção por pesquisar os dois grupos de profissionais deve-se a que estes compõem o corpo principal de trabalhadores responsáveis pela atenção às crianças nas creches. As coordenadoras organizam, supervisionam, avaliam, zelam pelas diretrizes do atendimento, veiculando o discurso oficial da Divisão de Creches. As educadoras realizam todo o atendimento direto às crianças. 
O convite às educadoras foi realizado durante as reuniões programadas nas creches. Em cada encontro, a pesquisadora apresentava sua proposta de estudo, destacando a intenção de realizar a coleta de dados de forma participativa, na oficina. Cada educadora recebeu um impresso contendo as informações sobre a atividade, a forma de participação e o prazo para as inscrições (Anexo 1). Houve dez inscrições, sendo sete da creche Oeste, duas da Central e uma da Saúde. Uma das educadoras da creche Oeste compareceu somente ao primeiro encontro.

As coordenadoras foram contatadas individualmente, esclarecidas quanto ao propósito da investigação e convidadas a participar como entrevistadas. Todas dispuseram-se a colaborar, totalizando-se 7 entrevistas. $\mathrm{Na}$ época da coleta de dados, uma pedagoga da creche Central encontrava-se afastada, prestando assessoria ao Ministério da Educação, não tendo sido, portanto, contatada para participar.

A caracterização das participantes foi realizada segundo roteiro padronizado (anexo 2), sendo que tais dados são apresentados e discutidos no eixo temático $\mathrm{A}$ creche.

\section{Aspectos éticos}

A fim de resguardar os direitos dos participantes e os aspectos éticos desta investigação, o projeto foi apreciado pela Comissão de Ética da Escola de Enfermagem da USP, que o aprovou em 22 de março de 2000 (anexo 3). O projeto foi encaminhado à direção da Divisão de Creches da Coseas, para ciência e endosso à autorização que já havia sido efetivada no primeiro contato. Realizamos uma reunião com a Diretora da Divisão, durante a qual foram discutidos alguns aspectos operacionais da coleta de dados.

As educadoras e coordenadoras das creches foram esclarecidas acerca do objetivo e finalidade do trabalho, forma de coleta dos dados e de apresentação no relatório, garantindo-se $o$ anonimato das informações. A todas que se interessaram em participar foi entregue o formulário de consentimento livre e esclarecido (anexos 4A e 4B), para sua concordância formal. Foi garantida sua liberdade para integrar o grupo de participantes bem como de 
deixar o estudo em qualquer momento, assim como afirmada a disponibilidade da pesquisadora para prestar esclarecimentos sobre o estudo, sempre que solicitados.

\section{Coleta de dados}

Souza Filho (1993) aponta que a observação participante e a entrevista com roteiros abertos são estratégias para a coleta de dados privilegiadas para estudos de representação. Isso porque permitem a aproximação à realidade natural do fenômeno, e facilitam a interação e a expressão "possibilitando o acesso do analista à realidade vivida pelo sujeito em sua relação com o objeto de representação e com outros sujeitos" . Estas estratégias têm sido utilizadas largamente nas pesquisas qualitativas.

Para a coleta de dados junto às coordenadoras, foi utilizada a estratégia de entrevista semi-estruturada. Conforme explica Minayo (1993), esse tipo de entrevista "combina perguntas abertas e fechadas (ou estruturadas), nas quais o entrevistador tem a possibilidade de discorrer sobre o tema proposto, sem respostas ou condições pré-fixadas pelo pesquisador".

A respeito da importância dessa estratégia para a coleta de informações, MINAYO (1993) afirma que a entrevista tem a "magia de transmitir, através de um porta-voz, as representações de grupos determinados, em condições históricas, sócio-econômicas e culturais específicas".

As entrevistas foram realizadas por mim, no próprio local de trabalho das participantes, em ambiente reservado e horário agendado previamente. $\mathrm{O}$ roteiro da entrevista continha as seguintes questões:

- Para você, qual é a função da creche?

- Quais as vantagens e as desvantagens da criança freqüentar a creche?

- O que é cuidar?

- Qual a relação entre cuidar e educar?

- Relate uma situação que você considera que representa um bom cuidado para a criança e uma situação que você considera que representa que uma criança não foi bem cuidada.

- O que significa cuidar da criança de outra pessoa? 
No decorrer das entrevistas, foram sendo elaboradas perguntas exploratórias, com a finalidade de esclarecer e aprofundar a compreensão acerca do que estava sendo exposto, tal como nos exemplos a seguir:

Você falou que principalmente para a criança pequena é importante flexibilizar as rotinas. É possível isso na creche?

Explique para mim essa distinção do individual e do coletivo, como é garantir o individual da criança e fazê-la aprender a viver com o coletivo?

E você acha que isso decorre da experiência da creche?

Houve, ainda, manifestações espontâneas sobre a percepção das coordenadoras em relação ao significado do cuidado para as educadoras.

Apenas uma das coordenadoras hesitou frente à questão que pedia para relatar uma situação que ela julgasse que a criança havia sido bem cuidada e uma situação que julgasse que a criança não havia sido bem cuidada, inclusive, retraindo-se na cadeira. Passado algum tempo, disse:

Sim... Um exemplo é difícil. A gente sempre procura fazer da melhor forma possível, mas somos passíveis de erros também, claro que tem alguns momentos em que tem uns deslizes aí, com certeza...

Foi-lhe então explicado que

O objetivo da questão não é verificar erros, não é observar, dizer " $a$ creche fez errado", mas é tentar ter mais elementos para caracterizar o cuidado. O que você julga que é um bom cuidado, o que você julga que não seja um bom cuidado, é isso que se quer.

Apesar desse esclarecimento, a coordenadora continuou hesitando, esboçou outra resposta, sobre a importância do período de adaptação, voltou a calar-se, denotando que ficara incomodada com a questão. Foi-lhe então oferecida a possibilidade de continuar falando sobre o período de adaptação da criança na creche e, a partir daí, a entrevista voltou a transcorrer sem dificuldades. Assim, considerei que ficou assegurado o direito da participante de recusar-se a responder a questão.

As entrevistas tiveram duração entre 30 a 90 minutos. Todas foram gravadas com consentimento das profissionais e depois transcritas na íntegra.

Souza filho (1993) indica, ainda, outras estratégias, como as técnicas projetivas e os jogos de dramatização, acompanhados da indispensável verbalização do próprio sujeito a respeito dos significados e intenções associados. A importância da verbalização é explicada por Farr (1999): "nas 
sociedades modernas, a linguagem é provavelmente quase que a única importante fonte de representações coletivas".

$\mathrm{Na}$ modalidade das técnicas projetivas associadas à verbalização, encontram-se as oficinas educativas. As oficinas educativas vêm sendo utilizadas e foram validadas como estratégias para a coleta de dados de pesquisa (Chiesa, 1993; Fonseca, 1996). Permitem tanto a explicitação de questões relativas à vivência das trabalhadoras, como sua discussão em grupo, no sentido de buscar a superação das dificuldades que têm maior magnitude. Constituem um espaço para reflexão e discussão das vivências e identificação de temas fundamentais para a compreensão do problema em pauta.

Chiesa (1993) enfatiza que, na relação dialógica, a comunicação no grupo é facilitada, permitindo superar a visão linear e superficial dos fenômenos em discussão.

Para a coleta de dados com o grupo de educadoras, optou-se pela realização de uma oficina educativa. Com isso, pode-se ampliar a participação dos sujeitos da pesquisa, promovendo o diálogo, na intenção de atingir "um processo coletivo de produção de conhecimento" (Sawaia, 1987).

O trabalho das oficinas alicerça-se numa relação horizontal entre técnicos e população, tendo em vista seus objetivos de resgatar os conhecimentos existentes, manifestar os sentimentos relativos à vivência, facilitar a expressão e a comunicação no grupo (Chiesa, 1993).

A realização de uma oficina compreende uma seqüência de encontros com uma temática geral delimitada a priori, organizados nos seguintes passos: aquecimento, uso de estratégias facilitadoras da expressão, problematização das questões, processo de troca, análise e articulação com o geral (Carneiro e Agostini, 1995).

É recomendável que haja duas pessoas responsáveis pela condução das oficinas: um coordenador e um observador. O coordenador é responsável por promover o diálogo no grupo, encaminhando, através dele, a solução de questões da qual participam pessoas com diferentes bagagens de saber (Carneiro e Agostini, 1993). Embora o coordenador tenha um papel e um poder 
diferenciado no grupo, Carlotto (1992) destaca que isto não significa que ele deva estabelecer relações autoritárias, de controle ou centralização.

No caso desta pesquisa, o papel de coordenador foi realizado por uma enfermeira com formação psicodramática e com larga experiência na utilização da estratégia. A autora da investigação atuou como observadora.

Foram utilizados elementos do psicodrama pedagógico como recursos facilitadores de expressão e do auto-conhecimento, visando a participação das pessoas no grupo.

Romaña (1992) adaptou e sistematizou a utilização de elementos do psicodrama à situação de ensino-aprendizagem. A autora explica que "há dois grupos de situações em que podemos utilizar essa metodologia: aquelas nas quais o conhecimento decorre de uma aprendizagem simultânea à experiência de vida e aquelas em que o conhecimento decorre da aquisição de saber na instituição escolar". Para ela, o método educacional psicodramático possibilita aos educadores transmitir o conhecimento do ponto de vista do consenso científico em que se encontra, bem como provocar rupturas na "ordem" ou "conservação" desses conhecimentos, estimulando novas respostas aos desafios e contradições da realidade.

Os encontros de grupo foram estruturados e conduzidos a partir de tópicos estabelecidos em conjunto pela coordenadora e pesquisadora, visando compreender o que os sujeitos do estudo pensam, sentem e fazem, em relação ao cuidado da criança (anexo 4).

Ao início de cada dia de trabalho, foi realizada uma atividade de "aquecimento", a fim de promover o entrosamento do grupo. Para a realização de cada sessão da oficina, a coordenadora percorreu os seguintes passos: solicitava aos participantes que se concentrassem no assunto em pauta; explicava, a seguir, que os conhecimentos, idéias e opiniões acerca do tema em pauta deveriam ser expressos com o auxílio das estratégias facilitadoras propostas. Nas três primeiras sessões, o grupo foi divido em dois subgrupos e, na última sessão, as pessoas trabalharam individualmente.

À medida que o grupo ia expondo seu trabalho, a coordenadora procurava torná-lo o mais concreto possível através de perguntas explicativas 
que permitiram posteriormente a discussão e problematização. Em todos os momentos, a participação das educadoras foi expressiva. Ao final, a avaliação delas foi unânime no sentido de que a oficina foi produtiva e contribuiu para a reflexão de uma maneira agradável, prazerosa. No anexo 5 , encontram-se as avaliações das participantes, de forma resumida.

\section{Análise dos dados}

Os encontros grupais bem como as entrevistas individuais foram gravadas e transcritas na íntegra. O material resultante das transcrições foi submetido à análise de conteúdo. De acordo com D'Urung apud Bardin (1977), a análise de conteúdo é aplicável a qualquer comunicação e é definida como "um conjunto de técnicas de análise das comunicações visando obter, por procedimentos sistemáticos e objetivos da descrição do conteúdo das mensagens, indicadores (quantitativos ou não) que permitam a inferência de conhecimentos relativos às condições de produção/recepção (variáveis inferidas) destas mensagens".

Dentre as diversas técnicas de análise de conteúdo, optou-se pela análise temática, por ser uma das formas mais adequadas à investigação qualitativa na área de saúde, conforme afirma Minayo (1993). Segundo a autora, "fazer uma análise temática consiste em descobrir os núcleos de sentido que compõem uma comunicação cuja presença ou freqüência signifiquem alguma coisa para o objetivo analítico visado".

Assim, os passos seguidos foram pré-análise, exploração do material, tratamento e interpretação dos resultados obtidos.

Na pré-análise, foi realizada a leitura flutuante, exaustiva, de cada texto transcrito, para a constituição do corpus, ou seja, o material foi organizado e validado pelas normas de exaustividade, representatividade, homogeneidade e pertinência. Nessa fase, foram sendo eliminados vícios de expressão, ou vocábulos coloquiais repetidos que não se faziam necessários à compreensão, bem como as questões e intervenções realizadas pela pesquisadora e pela coordenadora da oficina. 
Os dados obtidos foram analisados separadamente nos dois subgrupos (de coordenadoras e educadoras) e, posteriormente, comparados entre si.

A exploração do material seguiu com a atribuição de títulos, unidades de sentido, a cada trecho que continha uma idéia. Alguns trechos receberam mais de um título, permitindo uma descrição precisa das características do conteúdo e o alcance do núcleo de compreensão do texto. Abaixo, exemplifica-se a atribuição de unidades de sentido aos discursos.

\begin{tabular}{|l|l|}
\hline \multicolumn{1}{|c|}{ Discurso } & \multicolumn{1}{c|}{ Unidade de sentido } \\
\hline $\begin{array}{l}\text { Cuidado eu entendo como o atendimento às } \\
\text { necessidades da criança, físicas, afetivas, } \\
\text { emocionais, de relação, }\end{array}$ & $\begin{array}{l}\text { Cuidar é atender as } \\
\text { necessidades da criança }\end{array}$ \\
\hline aquilo que ela precisa prá viver e prá viver bem, & A criança precisa ser cuidada \\
\hline que ela depende em relação ao adulto & $\begin{array}{l}\text { A criança depende do } \\
\text { cuidado do adulto }\end{array}$ \\
\hline
\end{tabular}

Esse procedimento foi realizado nas sete entrevistas e no discurso das nove educadoras durante as reuniões. Toda a análise foi realizada com a preocupação de encontrar as unidades de sentido emergentes do discurso, sem pretensão de manter os mesmos títulos encontrados nas transcrições já analisadas. Foi obtido um grande número de unidades de sentido, que foram agrupados por afinidade e posteriormente reagrupados, observando-se a presença de associações entre eles, chegando-se a quatro temas: $\mathbf{A}$ creche, $\mathbf{O}$ trabalho na creche, $O$ cuidado da criança na creche e $A$ creche e a família. A apresentação de cada um dos eixos temáticos, foi iniciada com a exposição da análise das entrevistas com as coordenadoras e, a seguir, a análise das reuniões da oficina de reflexão.

Para a interpretação dos resultados, recorreu-se à literatura, a fim de descobrir em quais teorias explicativas estão ancorados os dados extraídos dos discursos das profissionais da creche, bem como observou-se a presença de associações entre as categorias, seja por convergência, divergência ou contradição.

A apresentação e discussão dos resultados foi ilustrada com trechos dos discursos. Para a apresentação dos trechos dos discursos que deram origem 
às categorias, procedeu-se à sua síntese, com o cuidado de manter o sentido original, visando tornar a leitura da tese mais fluente. Isso porque, na fala espontânea, há muitas quebras, repetições e expressões que podem tornar 0 discurso de difícil compreensão, particularmente quando recortado em trechos. Abaixo, é apresentado um exemplo de como foi feita a síntese.

Discurso original: Na relação do adulto com uma criança está implicada a necessidade que uma criança tem desse adulto porque ela não é capaz de fazer isso sozinha. Porque esse adulto precisa estar ali, e precisa estar ali prá que ela esteja bem, prá que ela esteja limpa, prá que ela esteja satisfeita e prá que ela tenha suas curiosidades todas, pelo menos, ouvidas, prá que esse adulto possa responder. Então eu acho que pra mim o cuidado teria que englobar essa visão de uma necessidade, de algo que é quase que inerente à própria relação do adulto com a criança.

Discurso sintetizado: A relação do adulto com uma criança implica a necessidade que a criança tem do adulto, porque ela não é capaz de fazer algo sozinha. $O$ adulto precisa estar ali, para que ela esteja bem, limpa, satisfeita e tenha suas curiosidades, pelo menos, ouvidas, para que ele possa responder. $O$ cuidado teria que englobar essa visão de necessidade, de algo quase inerente à relação do adulto com a criança.

Os trechos das falas selecionados para a apresentação foram grafados em fonte times new roman, para melhor visualização e diferenciação. 


\section{- A CRECHE}

No tema $\mathbf{A}$ creche, as áreas encontradas permitiram a identificação de três subtemas: funções da creche, a vida da criança na creche, e controvérsias sobre a creche. Para as educadoras, encontrou-se ainda 0 subtema desafios para a educação infantil.

Os resultados referentes às coordenadoras são apresentados no item 1, e os referentes às educadoras, no item 2.

\section{PARA AS COORDENADORAS}

\section{- Funções da creche •}

As coordenadoras apontaram como funções da creche: educar, educar e cuidar, promover socialização, suprir necessidades infantis.

\section{Educar / Educar e cuidar}

Todas as educadoras apontaram como funções da creche educar e cuidar, apresentando, porém, algumas diferenças.

A maioria (4) das coordenadoras definiu a creche como instituição de educação, afirmando que o cuidado inclui-se na função educativa.

Hoje em dia a função da creche tem um tanto da parte educativa bem forte, de preparar as crianças para saírem daqui e irem prá escola, e até o cuidado com a criança entra dentro dessa função educativa.

Para as crianças, é um espaço de educação. Quando eu cuido eu estou educando, quando eu educo eu cuido.

O educar prá mim é o todo, educar e cuidar é uma coisa só, e o objetivo mesmo nosso é o pedagógico em primeiro lugar.

A concepção de creche como instituição educativa é recente em nossa história, ainda que considerando que tanto a escola quanto a creche são instituições jovens. Em sua origem, as creches tinham como função primordial a guarda e proteção infantil, particularmente da infância pobre. A partir dos anos 70 , a sociedade civil passou a lutar organizadamente em defesa de novas propostas para a creche e pré-escola que foram legitimadas pela Constituição Federal de 1988.

Com a promulgação da Constituição Brasileira, a educação infantil tornou- 
se um dever do Estado e direito da criança, embora não obrigatória. O Estatuto da Criança e do Adolescente (lei o 8.069/90) e a Lei de Diretrizes e Bases da Educação (lei № 9394/96) vieram definir que as instituições para a criança de 0 a 6 anos sejam subordinadas ao órgão responsável pela educação nos municípios brasileiros.

\section{Chamboredon e Prévot (1986) explicam que}

"a descoberta da primeira infância como objeto cultural se explica por condições múltiplas, estando entre as principais o desenvolvimento e a difusão dos conhecimentos psicológicos. A psicologia conduziu à descoberta da primeira infância ao convencer-se da importância desse período para a constituição da personalidade e, sobretudo, para a formação da inteligência. (...) um dos principais efeitos (...) [foi] transformar a definição social da infância, fazendo recuar para a mais tenra idade o bebê, como objeto de cuidados fisiológicos e afetivos, e fazendo começar muito mais cedo a primeira infância como período que reclama, também, cuidados culturais e psicológicos. (...) Essa nova definição da primeira infância, das atividades e competências desta idade, formada em diversas fontes, penetra lentamente na escola maternal".

Mas é interessante considerar a análise de Kuhlmann Jr. (1991) a respeito da constatação de que o modelo assistencialista trazia embutido um modelo educacional, ainda que assim não se proclamasse. $O$ autor verificou que, na mesma época em que surgiram as primeiras creches no Brasil, no final do século XIX, "desenvolveu-se o setor privado da educação pré-escolar, voltado para as elites", este sim utilizando o termo pedagógico, como estratégia de propaganda. Contudo, o autor defende a idéia que todo modelo, ainda que não explicite, exerce uma função educativa. Nas palavras do autor:

"As instituições pré-escolares assistencialistas tinham uma perspectiva educacional coerente com as proposições de assistência científica, claramente dirigida para a submissão não só das famílias, mas também das crianças das classes populares. (...) É nesse período, por exemplo, que a matéria Puericultura passa a integrar os currículos das escolas normais bem como desenvolvem-se estudos de psicologia infantil e de métodos pedagógicos para a criança pequena".

Embora não tenha sido solicitada uma definição de educação nas entrevistas, foi possível identificar diferentes concepções acerca desse conceito, as quais certamente permeiam não só seus discursos como também suas práticas.

O enfoque predominante aborda a educação como um processo amplo que engloba a transmissão de conhecimentos, de cultura, de valores e regras 
sociais. Este inclui não só as atividades pedagógicas, como também o cuidado, o qual foi enfatizado enquanto promotor do bem-estar e das interações na creche.

A creche é um espaço educativo, e eu entendo a questão da educação não só do ponto de vista pedagógico. A educação engloba a transmissão de cultura, de conhecimento, de tradição, de valores, de regras de convívio, $e$ nisso é que está incluída a questão tanto pedagógica, formalizada, de transmissão de conhecimento, quanto de um cuidado no sentido de um estabelecimento de vínculo com as crianças, onde é cuidar daquilo que signifique bem-estar e relações de qualidade.

O pedagógico é o todo, não é só eu estou alfabetizando ou não. Na alimentação, é o sentar na mesa, o usar os talheres, é a cidadania, respeitar o amigo, os educadores, é um todo. Bem sintetizado, é isso.

Tais definições têm pontos em comum com o Referencial Curricular Nacional para a Educação Infantil (Ministério, 1998) que inclui o cuidar e o brincar como itens do educar:

"Educar significa, portanto, propiciar situações de cuidados, brincadeiras e aprendizagens orientadas de forma integrada e que possam contribuir para 0 desenvolvimento das capacidades infantis de relação interpessoal, de ser e estar com os outros em uma atitude básica de aceitação, respeito e confiança e 0 acesso, pelas crianças, aos conhecimentos da realidade social e cultural".

Segundo o Referencial, a finalidade da educação é "auxiliar o desenvolvimento das capacidades de apropriação e conhecimento das potencialidades corporais, afetivas, emocionais, estéticas e éticas, na perspectiva de contribuir para a formação de crianças felizes e saudáveis". Considerando a definição acima citada, a finalidade deveria incluir também as potencialidades cognitivas.

Outro enfoque, apresentado por uma única coordenadora, privilegia o saber constituído como saber escolar: da língua (escrita e leitura), da matemática, das artes e ciências. Nessa visão, defende-se que é função da creche preparar a criança para a escolarização, oferecendo conhecimentos formalizados, para favorecer seu ingresso no ensino fundamental.

[A criança] tem que aprender, prá poder ir prá escola sabendo coisas. [a creche] ensina a ler, escrever, conhecer pintores. Tudo isso faz parte da educação prá ela chegar na primeira série com um conhecimento que ela é capaz. [A parte educativa] são as atividades planejadas previamente, pensadas, não são aleatórias, tem um estudo posterior, qual é a faixa etária, o que nós vamos ensinar prá ela. Se esse grupo aprendeu melhor num ano, no outro ano você troca ou aperfeiçoa o projeto, você leva em 
consideração a faixa etária ou a experiência que você já viveu.

Essa concepção surgiu na década de 80 , em experiências isoladas em diversos Estados brasileiros e na literatura especializada, visando a superação do determinismo assistencialista em vigor nas instituições de atendimento à criança. Chamados genericamente de educacionais, esses novos modelos enfatizavam o planejamento e programação pedagógica das atividades junto às crianças.

Exemplificando, durante o Congresso Comemorativo dos 50 anos de Educação Pré-Escolar da Rede Municipal de Ensino de São Paulo, Kramer (1985) conclamou para a luta pela valorização da pré-escola "na próxima Constituinte", defendendo como papel social da pré-escola "contribuir para a escola de $1^{\circ} \mathrm{Grau}$, valorizando e ampliando os conhecimentos que as crianças possuem, e garantindo a aquisição de novos conhecimentos (...) articulados a sua realidade sócio-cultural e estágio de desenvolvimento".

Entretanto, em muitos casos, houve importação do modelo do ensino fundamental para as creches e pré-escolas (Kramer, 1985), criando situações nada compatíveis com as características e necessidades da criança pequena. Este é, inclusive, um dos aspectos conflitantes do Referencial (Ministério, 1998), no qual a educação infantil é tratada, às vezes, como ensino, utilizando terminologia e conteúdos disciplinares correntes nos níveis posteriores de ensino. O cuidado aparece como secundário, um meio para promover 0 desenvolvimento. Isto desperta a idéia de que o documento privilegia 0 educativo estabelecendo o viés da escolarização infantil desde o nascimento.

Para as coordenadoras que definem a creche como espaço de educação e cuidado, uma das razões apontadas é a característica de atendimento em período integral e outra é que o cuidado seria função da educação.

Eu parei para pensar que função é essa, quando você tem crianças que passam 9, 10, 11, horas dentro da instituição. A creche tem duas funções básicas do cuidar e do educar.

Com a instituição de período integral, você vai tendo que olhar para cada detalhe, a importância do cuidar, que o pedagogo não tem um olhar maior.

Creche serve prá atender crianças de 0 a 6 anos, no que diz respeito a educação e cuidados. Cuidados cada vez mais entendido como função da educação. 
A legislação brasileira atual determina que a creche é parte integrante do sistema escolar, mas a política educacional a define como instituição educativa sem caráter escolar, enfatizando que "é no binômio educar e cuidar que devem estar centradas as funções complementares e indissociáveis dessa instituição" (Nascimento, 2000).

Assim, a noção de que é devido ao atendimento em período integral que se configura essa dupla função é restrita.

Também é incompatível com a concepção de Kulhmann Jr. (2000) que afirma:

"a caracterização da instituição de educação infantil como lugar de cuidado-eeducação adquire sentido quando segue a perspectiva de tomar a criança como ponto de partida para a formulação das propostas pedagógicas.(...) A expressão tem o objetivo de trazer à tona o núcleo do trabalho pedagógico conseqüente com a criança pequena. Educá-la é algo integrado ao cuidá-la".

Segundo a visão desse autor, essa função da creche independe do tempo de permanência da criança, mas é inerente à característica que deve ter o atendimento infantil: de aproximação ao ponto de vista da criança de, ao invés de sistematizar o mundo para apresentá-lo à criança, deixá-la vivê-lo, proporcionando-Ihe experiências ricas e diversificadas.

Essa idéia é também defendida por Wilheim (1991), para quem a concepção de creche e pré-escola como instâncias educativas incorpora uma dimensão de assistência à pequena infância, dadas as características da faixa etária e a perspectiva de assegurar simultaneamente educação e cuidados.

A definição de educação, segundo as coordenadoras, enquadra-se também na visão sociológica.

(...) educação como uma coisa ampla, educar como o ingresso da criança no universo cultural, social, do qual a gente participa e no qual a gente cria.

Todos os atos são educativos. A gente tem que inserir a criança num mundo social, em todos os sentidos.

Tendo como proposta inserir a criança no mundo social, foi citado como função dos educadores estimular o desenvolvimento de virtudes, regras de convivência e valores éticos.

Eu venho estudando, pensando muito, a questão da ética. Eu não posso jogar uma criança aqui se o profissional só tem o olhar para a questão da 
aprendizagem. Eu tenho que ensinar a polidez para a criança, porque tem muito a ver com o trabalho educacional. Há trinta anos atrás, a criança aprendia isso com os pais "você pegou uma coisa da mão da Maria De La Ó, toma cuidado, não pega de qualquer jeito". Só que fica esse conflito entre os pais e os educadores: quem ensina? E a criança não aprende com ninguém, e vai virando uma bola de neve essa situação. Se o pai não está ensinando polidez do jeito que a gente queria, a gente não vai entrar na família de qualquer jeito, mas é o nosso papel, enquanto educadores, ensinar como se relacionar com o outro, não só no aspecto do cognitivo, mas como falar, como pedir, como agir, como olhar, e a gente não aprende isso na faculdade.

Por considerar a importância de desenvolver os valores éticos no processo educacional, a coordenadora lamenta que o Referencial Curricular Nacional para a Educação Infantil não aborde esse aspecto. Lembra que está inserido no documento "Parâmetros Curriculares da Educação Infantil" e que tem utilizado esse material para discutir com as educadoras questões desse âmbito que emergem no dia a dia.

Os parâmetros [curriculares], falam da questão da ética na educação e nos ajudam a pensar situações do cotidiano que a gente precisa trabalhar. A questão das virtudes, que é a polidez, a generosidade. Em algumas situações as crianças têm isso espontaneamente e o educador, por uma falta de formação, ele poda. Um exemplo do que vem acontecendo: as crianças, no começo do ano, trazem os materiais pessoais; uma criança não tinha trazido e a outra falou assim "eu posso emprestar para ela", só que a educadora, eu sempre falo "não é por mal", mas ela pensou "não usou nem uma vez e já vai ter que emprestar para o outro, isso não é justo", então ela falou "não pode emprestar agora porque ela ainda não tem". São situações que acontecem e por uma falta de formação, de um conhecimento da importância disso na vida hoje, você até poda e não cria situações e muito menos valoriza o que vem acontecendo.

É possível compreender as dificuldades para lidar com questões que a coordenadora inclui como do âmbito da generosidade: em nossa sociedade, valoriza-se o eu e o ter, o individual e o privado, em detrimento do coletivo e do público. As educadoras também estão imersas nessa cultura e terminam por reproduzir tais valores junto às crianças, o que evidencia o caráter reiterativo que a instituição pode ter, apesar das propostas em contrário. 


\section{A creche promove interações sociais}

Favorecer a socialização ou promover situações de interação social é apontado como uma das principais funções da creche para as crianças, inclusive destacada como uma vantagem para as usuárias em relação àquelas que não freqüentam esse tipo de instituição.

É importante a criança desde muito pequena ir para uma escola, para uma creche, ir conviver com outras crianças. As parcerias enriquecem muito. Ela se socializa muito cedo, isso é o lado positivo.

Cada vez mais é importante a presença das crianças num espaço institucional com convívio com outras crianças. Ter, além da família, um lugar onde essa criança esteja. Que desde bastante cedo ela possa usufruir do contato com outras crianças pequenas e com outros adultos; das relações sociais mais diversas, as diferenças entre adultos, as diferenças entre as crianças.

$\mathrm{Na}$ instituição tem os amigos, vai tendo uma relação, experimentando outras pessoas, outros adultos, isso enriquece, essa rede de conhecimentos, tanto cognitivo como afetivo, é fundamental.

A vantagem da socialização infantil na instituição ocorre em virtude da variedade de relações que ela estabelece, graças à diversidade de adultos e crianças com as quais se dá a convivência diária assim como à variedade de atividades que são oferecidas. Tudo isto resulta numa aprendizagem que favorece o desenvolvimento infantil.

Com certeza, na creche é super favorável, a diversificação das atividades. A criança começa a desfrutar dos processos de interação com outras crianças, com as crianças mais velhas.

Desde bebê, é muito mais saudável o convívio com outras crianças, numa creche como essa que tem uma diversidade de famílias, de pessoas, de crianças, de todos os jeitos, isso é super enriquecedor, ajuda uma barbaridade quando vai prá escola, pública ou privada.

O processo de socialização no ambiente institucional coletivo implica a aprendizagem de normas específicas, muitas vezes diferentes das de casa.

Tem diferença. Na casa, ela domina o espaço, vai entrar na cozinha. Aqui tem normas, você está pensando na integridade física dela, tem outros amigos, tem que respeitar, aprende a hora de falar, levanta a mão porque tem que respeitar o amigo, se todo mundo fala junto ninguém entende.

Segundo Musatti (1998), as pesquisas no campo da creche evidenciaram

"que os limites entre aquilo que tradicionalmente era definido como socialização 
primária (de incumbência da família) e socialização secundária (de incumbência de outras agências) vão se diluindo cada vez mais. No plano do desenvolvimento psicológico, esse dado coloca em crise as teorias (...) que afirmam a necessidade das crianças em adquirir estruturas estáveis de socialização primária antes de ampliar suas experiências e outras formas de sociabilidade".

A autora continua dizendo que crianças que freqüentam creches vivem experiências simultâneas de formas de sociabilidade na família e na creche e, portanto, "não é possível isolar a contribuição da experiência da creche no desenvolvimento da criança", bem como "a freqüência à creche modifica, direta e indiretamente, a natureza da experiência em família". Mas que é possível afirmar que as relações com os coetâneos, com as crianças de idades diferentes e com os adultos, todas são formas importantes de sociabilidade e, portanto, influem na estruturação dos processos afetivos e cognitivos infantis.

\section{A creche supre necessidades da criança}

Toda a atenção do serviço está direcionada para a criança, uma vez que as atividades realizadas visam atender suas necessidades. Isto se dá na maneira como se organiza o ambiente, a rotina, provendo oportunidades de desenvolver o potencial infantil.

A função é estar proporcionando para a criança todas as oportunidades para ela realmente se desenvolver no todo.

Fora a socialização, tem outras coisas: a creche organiza o espaço, o berço, o lugar onde vai dormir, como vai ser a atividade naquela semana, que brincadeira é mais gostosa, mais adequada para estar recebendo aquela família, o espaço físico. Tem uma contribuição muito grande da gente, [o processo de desenvolvimento] vai acontecer na vida dele, mas a maneira como a gente vai estimulando, organiza e deixa o ambiente interessante, é fundamental.

De uma maneira que seja cuidada, não na rua, não numa situação qualquer, mas é um ambiente pensado, onde se conversa e se está ali para atender as crianças.

Permite que a criança se desenvolva bem porque é um ambiente adequado ao universo infantil. Graças à possibilidade que a creche tem de oferecer oportunidades para a criança se desenvolver e se inserir na cultura de seu meio, as crianças que podem dispor desse serviço teriam uma vantagem em relação às que não podem. Torna-se particularmente importante quando se considera a organização social atual, pois, segundo as coordenadoras, a 
realidade freqüente é aquela em que os pais não estão disponíveis para fornecer as melhores condições para o desenvolvimento infantil. Mas essa afirmação é postulada juntamente com a consideração de que isto se dá porque o modelo de atendimento já não é mais o antigo assistencialista.

Principalmente pensando no mundo de hoje, onde não se tem mais a mãe em casa, a mulher saiu para o mercado de trabalho, às vezes a criança fica muito no mundo do adulto, com empregada ou com outras pessoas, e na creche tem o espaço organizado para ela, com brincadeiras, com atividades, pensando no universo infantil, na educação.

Hoje em dia, numa realidade em que a mãe trabalha, o pai trabalha, quais são as possibilidades, as ofertas reais prá essa criança, dela entrar nessa cultura, dela se desenvolver enquanto pessoa, enquanto individualidade? A creche oferece isso de um jeito muito bom. E cada vez melhor, porque a creche cada vez aprende mais a fazer isso. A gente vive num momento inaugural, novo, em relação à educação infantil. A gente está aprendendo a ser bom nesse caminho de respeitar essa individualidade, de saber conhecer essa criança, de criar um bom ambiente prá que ela possa se desenvolver, de uma forma já muito diferente daquele jardim de infância, daquela creche naquele modelo assistencialista.

A creche oferece o que a família não pode oferecer em virtude de suas condições de vida: atividades diversificadas, promove a independência, estimula o aprendizado da convivência e protege dos perigos da rua.

Por volta de um ano, [a criança] passa a pedir atividades diferentes, que muitas vezes em casa não há disposição e acaba ficando muito na tv.

Eu só vejo vantagem para a criança, de freqüentar a creche. Na prática, eu vi todas as crianças, a independência, é uma criança crítica, totalmente diferente [porque] a creche dá oportunidades diferentes. Em casa é difícil, fica com a avó ou com babá, é ela só. Aqui, a criança aprende realmente a trocar, a viver no coletivo, principalmente nessa creche que é tudo muito coletivo, embora se respeite o individual. Sou totalmente a favor da criança ir para a creche ou escolinha.

Diferente de quando eu era criança, tinha a rua para a gente brincar, não tinha os perigos que tem hoje, numa cidade grande como São Paulo. Na sociedade de hoje, principalmente na cidade de São Paulo, é fundamental a criança ir para a escola.

Essas falas se coadunam com a idéia que vem sendo difundida atualmente, a respeito da creche como direito da criança e não só da mãe, estando, portanto, potencialmente dirigida a todas as crianças, tendo como finalidade atender suas necessidades específicas de desenvolvimento. Ao mesmo tempo, corroboram o ponto de vista de Bondioli e Mantovani (1998) de que a creche, como serviço, tem como referente a família. Para as autoras, "é 
realmente uma abstração pensar nas necessidades da criança como aspectos separados da realidade social na qual se encontra inserida e, portanto, das necessidades da própria família".

No último trecho apresentado, desponta uma questão que poderia vir a ser melhor estudada: Em que medida nossa organização social prevê espaços para a criança? Parece que, na verdade, o mundo de hoje não é feito para a criança, principalmente quando pensamos na desorganização da nossa urbe.

Foi feita apenas uma referência à creche como um serviço que atende à necessidade da mulher trabalhadora.

Primeiro tem essa coisa da creche ser um serviço, principalmente a creche dentro da universidade, atende uma comunidade com um número grande de mulheres.

Pensando no processo de desenvolvimento infantil, a creche tem ainda a função de oferecer uma base de segurança, que é vista como preparatória para o crescimento infantil e futuro aprendizado escolar.

$O$ trabalho de zero a 3 [anos] é fundamental. Se você estabelece um bom vínculo com a criança, uma tranqüilidade na hora de organizar o espaço, na hora da refeição, na hora do sono, ele é base para tudo. Se você faz um bom trabalho nesses primeiros anos de vida, ele é fundamental para a criança crescer e depois aprender a ler, a escrever, ela vai se sentir mais segura.

A esse respeito, Musatti (1998) refere que a hipótese de que a qualidade de vida e as experiências da criança nos primeiros anos de vida deixam uma "marca permanente na estruturação de seus processos cognitivos e afetivos" jamais foi provada, mas é amplamente aceita.

\section{- A vida da criança na creche}

Ao exporem seus conceitos sobre as funções da creche e sobre o cuidado, as coordenadoras descreveram intervenções que julgam fundamentais para o bem-estar da criança. Em todos os depoimentos, pode-se extrair preocupação em proporcionar as condições mais adequadas e satisfatórias para a criança.

A criança não tem que sofrer prá ir para a creche. A gente tem que saber cuidar, saber receber, de uma forma boa, gostosa, que seja um ambiente muito prazeroso. Com limites claros, limite não é sinônimo de sofrimento, é 
uma coisa que organiza e dá segurança para a criança. Mas o jeito de receber a criança quando ela chega as primeiras vezes na creche, quando ela começa a construir sua historinha, tem que ser muito acolhedor, muito cuidado, o esmero tem que ser grande. E isso tem que se manter ao longo da trajetória da criança na creche, como um ambiente acolhedor, que saiba reconhecer as necessidades, que saiba o momento de colocar limite, de dizer um não, um não de fato organizador.

Esse depoimento expressa uma certeza da coordenadora relativa à importância da adaptação da criança na creche enquanto uma experiência capaz de criar o alicerce necessário, a pedra angular, sobre a qual se constrói uma vivência emocional positiva, consistente, para que a vida da criança na creche seja boa. Mostra também a visão do direito infantil de viver experiências prazerosas, muito diferente de situações bastante comuns ainda em nosso meio em que as crianças são inseridas em novos ambientes (como creches e pré-escolas) sem apoio apropriado, pois acredita-se que "com o tempo ela acostuma". Conforme Mantovani e Terzi (1998) as objeções à creche, em nome do perigo de um trauma da separação, revelaram-se sem fundamento científico, "mas estimularam o emprego de uma grande delicadeza e a realização de análises atentas do processo de inserção, até torná-lo a primeira experiência educacional". Assim, o debate e a literatura científica sobre o tema da adaptação da criança na creche vem crescendo ${ }^{1}$.

O depoimento a seguir explicita como estão organizados diversos momentos de interação entre a creche, a criança e a família, a fim de atender as peculiaridades do processo de adaptação.

O primeiro contato que a família tem com a creche é a entrevista. A gente pergunta bastante sobre a vida da criança, a rotina dela, e tem uma troca, a gente conta um pouco do trabalho, da rotina. Na entrevista participa uma educadora do grupo da criança, que em geral vai ser a referência quando ela for entrar. Depois a criança vem para um exame médico, pela pediatra da divisão de creches. Antes da entrada das crianças, a gente faz uma reunião com as educadoras e a equipe técnica, mas quem comanda na verdade essa reunião são as educadoras, que a gente conta do trabalho, da rotina, dos projetos que são desenvolvidos, e vai se fazendo um caminho. São quase 50 crianças ou até mais, que entram, todos os anos. Em geral, entram duas crianças por semana, sempre uma na terça outra na quintafeira em cada grupo. Cada grupo tem duas ou três educadoras, um número muito grande, e a gente acha importante estabelecer uma referência para

\footnotetext{
${ }^{1}$ Durante curso promovido pela EEUSP e Grupo Saúde em Creches, em outubro/novembro de 1999, a adaptação foi classificada como um tema de saúde, em razão de sua importância para o desenvolvimento infantil.
} 
ajudar tanto a criança e principalmente nesse primeiro momento as famílias, situando o espaço, apresentar a creche, as pessoas que trabalham aqui. A gente pede para as famílias ficarem um tempo com a criança, e a saída é gradativa. Conforme a criança vai se ligando mais ao adulto, às brincadeiras, a gente pede para a família, a mãe ou o pai, sair um pouquinho, ficando aqui fora e a gente vai vendo como que a criança responde. E vai ampliando esse espaço, até que a criança esteja bem. E tem o momento da família ir embora, não ficar mais aqui acompanhando.

Alguns itens evidenciados como pontos-chave do processo de adaptação podem ser qualificados como ações de cuidado à criança e família, embora não tenham sido assim enunciados: 1) fase de conhecimento recíproco creche, família e criança, mediante a realização da entrevista, reunião e exame de saúde; 2) indicação de uma educadora de referência, responsável por acompanhar de perto a criança e a família durante o período de adaptação; 3) entrada gradativa das crianças, permitindo maior atenção nos primeiros momentos de sua presença na creche e 4) presença de um membro da família junto à criança até que ela adquira confiança nas educadoras.

Uma preocupação revelada foi a de proporcionar um atendimento individualizado à criança, ainda que no ambiente coletivo da instituição. Isto é assegurado desde o período de adaptação, graças a tais cuidados durante essa fase.

Tem momentos que tem que ficar mais com uma criança, a própria adaptação, ele está sendo colocado no coletivo, mas a gente dá atenção para ele, como ele fica, vê como ele reage nesses dias. É por aí que a gente consegue lidar bem com as individualidades no coletivo, é uma coisa que a gente está sempre atenta mesmo. "Eu quero um brinquedo, eu quero levar uma fita, quero levar um brinquedo da creche”, dar atenção para cada um, numa briga, numa coisa.

Ser flexível e rever regras estabelecidas também foi enfatizado como a maneira de atender bem as crianças. Exemplificando, ao modificar as regras e permitir que as crianças passassem a ter a opção de trazer um brinquedo seu todos os dias, a coordenação solidifica sua proposição de asseverar a individualidade das crianças. Garantir o espaço da individualidade traz um sentimento de segurança que favorece também o aprendizado necessário para lidar com as imposições da convivência em grupo.

Por muito tempo, se defendeu que a criança tem que aprender a dividir os brinquedos da creche, e o seu brinquedo, ela trazia um dia da semana. Mas ela podia brincar com as coisas dela: a mochila, a caixa, o lugar de 
guardar o seu sapato. Hoje, a gente já está muito mais flexível. Pode trazer o brinquedo dela todo dia e, se não quiser, ela tem todo o direito de não emprestar. $O$ brinquedo da creche ela tem que aprender a emprestar. Agora, eu posso fazer essa troca, deixar que ela tenha essas duas coisas na mão: a possibilidade de dividir e a segurança de que tem um que ela não precisa dividir, todos os dias.

Para a criança pequena, a gente oferece três momentos de sono: após o lanche da manhã, após o almoço e após o lanche da tarde; e entre o horário de dormir e o horário das refeições tem o espaço das atividades, das brincadeiras. As crianças não precisam percorrer todos esses momentos: se é hora da brincadeira mas tem crianças que estão com sono ou estão querendo fazer outra brincadeira tem essa flexibilidade. A gente organiza os momentos e os adultos distribuindo, e eu vou ter sempre alguém no berçário se uma criança quer dormir. Se é o momento de refeição e algumas crianças estão dormindo, a gente respeita esse ritmo e a hora que ele acordar a gente vai oferecer a refeição.

A flexibilidade permite alcançar resultados satisfatórios em situações que se iniciam "problemáticas", pois, num esquema flexível, cabem medidas criativas, compartilhadas entre a creche e a família.

A gente tem que interrogar as situações todas: como é que a gente fica bom prá essa criança que está com dificuldade de se sentir bem na creche? E a gente tem feito isso, a gente inventa situações novas, engraçadas até muitas vezes, de ver quem faz a adaptação da criança, quem é a melhor pessoa. A gente já teve situações da criança ficar aqui um mês e não conseguir desgrudar da mãe e aí a gente ir percorrendo a família, vem a vizinha, vem a prima, até que a gente achou um vínculo que era melhor prá fazer essa passagem. Não desistir, porque quando a gente interroga, a gente não desiste.

Atender bem a criança na creche, por causa do período integral, requer planejar atividades diversas para os períodos da manhã e da tarde:

A gente vem aprendendo também que tem que cuidar para não espelhar a rotina do período da manhã com a rotina do período da tarde. Uma criança de meio período, ela vai para escola, volta e desfruta do espaço de casa de um outro jeito.

\section{E evoca a necessidade de incluir nas ações junto às crianças a} transmissão de regras sociais, hábitos.

Que hora essas crianças aprenderiam os hábitos, sociais mesmo, de sentar na mesa, de comer com garfo, que são coisas da civilização, da educação? Porque na família, a gente vai transmitindo essas regras sociais, a gente fala, não come de boca cheia, ensina a comer com o garfo. Na instituição, quando as crianças passam o dia inteiro, algumas não têm esse contato com a família durante a semana, só no fim de semana. Então tem que estar sendo feito com os educadores, como mais um ato educativo, tanto quanto fazer a experimentação de uma salada, tanto quanto estudar a Grécia, quer 
dizer, a gente tem que estar inserindo a criança num mundo social, em todos os sentidos.

A instituição precisa garantir o espaço da brincadeira para a criança pequena.

Já que as crianças não brincam mais na rua, ficam o tempo inteiro em cima da televisão, olhando, de uma forma passiva, a instituição precisa garantir esse brincar. Poder brincar, do educador ensinar as brincadeiras.

E, finalmente, salienta-se a importância de atender às necessidades da família, a fim de melhorar a situação da criança.

Na minha experiência de 15 anos na creche, não tem criança que não se adaptou, tem famílias que não se adaptaram, não agüentaram. Já tivemos família que ficou aqui mais de 1 mês, um tempo longo, em geral é necessário. Quando a mãe está bem, Maria, está tranqüila, está segura, é mais fácil para ela se desligar e falar "olha, agora eu vou trabalhar e você vai ficar com fulano e com ciclano, vai brincar e é gostoso", porque ela passa essa segurança. Quando a família é insegura, é muito difícil a separação, por isso é importantíssimo a presença deles aqui.

É super importante, a adaptação ser o mais tranqüila para a criança e para a mãe, claro. E se é para a mãe, ela vai passar isso para a criança. A gente nunca fez mas seria importante fazer, como a A. faz, que é a mãe ir para a creche antes, conhecer, sentir o trabalho, porque aí tranqüilamente ela vai passar para a criança mais segurança, confiança.

Reforçando essa idéia, foi relatado já terem ocorrido situações em que a família desiste de continuar com a criança na creche. Numa das vezes, uma mãe chegou a manifestar que percebia que a criança estava bem mas que ela (mãe) não estava agüentando deixar a criança.

As coordenadoras têm uma atitude de responsabilidade e compromisso que se evidencia pela amplitude de questões relativas ao atendimento infantil com as quais estão preocupadas. Ainda, quando se deparam com novas situações, para as quais não têm respostas, tomam para si a incumbência de buscar formas de encaminhamento refletidas e pertinentes.

\section{- Controvérsias sobre a creche}

A questão acerca das vantagens e desvantagens da criança freqüentar a creche geraram algumas respostas controversas, indicando percepções até mesmo opostas entre as coordenadoras. 
Foram citados como desvantagens da creche: os limites à individualidade gerados pela "divisão de tudo" e porque todas as decisões se restringem pelos interesses coletivos; a permanência em período integral, considerada muito longa, especialmente para as crianças menores; a ausência de uma figura única de ligação afetiva. Algumas destas são apresentadas como possíveis causadoras de efeitos deletérios ao desenvolvimento infantil.

$\mathrm{Na}$ instituição, por mais que nós tenhamos um olhar para a questão do individual dentro do coletivo, eu não posso deixar uma criança que está com vontade de ficar na oficina de informação lendo um livro, sozinha. Ela tem ficar junto com o grupo porque tem que ter supervisão, mesmo tendo autonomia, tem que ter o olhar do adulto. A gente até pode mudar isso, mas ainda não tem condições de ter essa flexibilidade maior.

O período integral, para algumas crianças, é bastante longo. As creches têm essa função, porque os pais trabalham, mas para algumas crianças até 3 anos, ou para qualquer criança na pré-escola, às vezes é extremamente estressante estar num ambiente institucional, onde se divide basicamente tudo. A marca do ambiente institucional é a ausência da família, especialmente a ausência da mãe, e cada vez mais também a ausência do pai, que está mais presente no cuidado, mas também a divisão de tudo, um espaço onde tudo é coletivo, até o adulto que cuida dele. Na casa se dividem as coisas mas tem um espaço bastante individualizado, tem uma falta de rotina regradinha e uma instituição que tem 250 crianças, não dá para cada um comer na hora que quer. Mesmo que eu ache que eu não tenho que respeitar totalmente isso, mas não dá para cada um ter vontades, é impossível, não posso fazer a cozinha funcionar desse jeito, não tem como funcionar o lactário, eu tenho um tanto de flexibilidade que, para algumas crianças, é uma imposição drástica.

Eu questiono um pouco, para a criança muito pequenininha, o período integral. Eu sinto que, às vezes, as crianças pequenas ficam um pouco cansadas. Sabe, aquele momento de ficar no seu cantinho, com as suas coisinhas, e aqui é tudo muito coletivo Maria, na hora de comer todo mundo senta junto, o brinquedo é de todo mundo, por mais que a gente tente deixar um momento de ficar na almofada quietinha, é o barulho, a outra criança, tem a rotina que tem que se seguir, agora é hora de dormir, agora é hora de comer, que é importante para a criança, para ela se organizar, mas ela precisa um pouco dessa coisa individual, de um cuidado individual, de estar sozinha, sem precisar dividir sempre tudo, os brinquedos, o adulto. Talvez o meio-período seria o ideal.

Essas questões evocam a idéia de que a melhor estrutura para a criança seria o modelo de família nuclear, em seu próprio lar e que o cuidado que a criança necessita seja intrínseco a essa estrutura. Esta é uma representação social construída bem recentemente na história ocidental. Estudos históricos acerca da família evidenciam seu caráter de instituição social dinâmica, que 
assume características e sentidos em conformidade com os sistemas de valores, crenças e práticas vigentes no meio e no tempo em que se constitui.

Ariès (1981) analisa as transformações ocorridas na família desde o período medieval até o contemporâneo, verificando a existência de profundas diferenças durante sua evolução. Até o século XV, a família era uma realidade moral e social mais do que sentimental. As crianças eram educadas e socializadas na casa de outras famílias que não as suas.

Os moralistas e os educadores do século XVII despertaram um sentimento da infância que inspirou toda a educação até o século $X X$ : as crianças como frágeis criaturas de Deus que era preciso preservar e disciplinar. A literatura e a propaganda da nova ordem moral ensinaram aos pais que eles eram guardiões espirituais, responsáveis perante Deus pela alma e pelo corpo de seus filhos.

A família deixou de ser apenas uma instituição de direito privado para a transmissão dos bens e do nome, e assumiu uma função moral e espiritual, passando a formar os corpos e as almas. $O$ cuidado dispensado às crianças passou a inspirar sentimentos novos, uma afetividade nova: o sentimento moderno de família. A moral da época impunha aos pais proporcionar a todos os filhos, não somente ao mais velho e, no fim do século XVII até mesmo às meninas, uma preparação para a vida (Ariès, 1981).

Em relação à questão da "divisão do adulto", Mello (1999) explica que "se a instituição quiser pautar seu atendimento no modelo materno-substitutivo, precisa garantir o que pede a literatura norte-americana", ou seja, "um adulto para cada 3 crianças de 0 a um ano e meio". Por outro lado, uma concepção de creche como um "contexto que, em função de suas características, oferece oportunidades específicas e complementares àquelas da família e constitui um ambiente de socialização e educação de crianças em grupo, complementar à família, e não uma tentativa de reprodução do ambiente familiar", pode prever uma razão adulto-criança um pouco mais alta. Isso desde que se "organizem espaços mais práticos para os adultos, ao mesmo tempo seguros e estimulantes para os bebês", bem como "estratégias que permitam às crianças relacionarem-se entre si e possibilitem ao adulto maior atenção individual às crianças ou grupos que necessitem" (Mello, 1999). 
Há algumas diferenças entre as três creches (Central, Oeste e Saúde), em relação à proporção educadora/crianças, devido às divisões etárias e ao tamanho dos grupos de crianças. À época da coleta de dados, a razão adulto criança estava em torno de $1 / 5$ para os bebês e 1/7 para o grupo das crianças de 2 a 3 anos incompletos, nas creches Oeste e Central. A creche Saúde só tinha crianças com mais de 3 anos de idade. Esses valores encontram-se em conformidade com o preconizado por Wilheim (1991).

Quanto ao período integral, uma coordenadora posiciona-se francamente favorável, justificando que, ficando apenas meio período, a criança sofre prejuízos em relação às outras.

Eu sou super a favor do período integral. Acho que tem que vir bebê e tem que ficar período integral. Porque eles perdem muito. Apesar de a gente sempre tentar fazer uma coisa para quem está meio período não perder, entre aspas, na comida, no brincar, nas áreas do conhecimento, quem fica meio período acaba sempre perdendo um pouco.

Aqui, nota-se a idéia da educação compensatória, voltada para o atendimento das crianças carentes ou "privadas culturalmente", às quais faltam determinados atributos, atitudes ou conteúdos. A idéia da carência cultural foi desenvolvida nos Estados Unidos e teve grande repercussão no Brasil, tendo sido adotada como diretriz pelo Estado. Os programas de educação préescolar de cunho compensatório se incumbiriam de suprir deficiências de saúde e nutrição, as escolares, ou as do meio sociocultural em que vivem tais crianças, visando resolver o problema do fracasso escolar (Kramer, 1984).

Outra coordenadora considera que há algumas situações particulares em que o período integral pode não ser satisfatório.

Essa idéia de que meio periodo é bom mas período integral já é demais, eu não penso assim. A gente tem condição de ser bom para a criança período integral, criar um bom ambiente, dar boas respostas. Tem crianças que ficam aqui em período integral de um jeito muito bom. Isso é uma regra? Não. Tem criança que fica anos em período integral e de repente sente falta, quer ficar um pouco em casa e a gente acaba chegando à conclusão com a família "agora acho que é bom se ela puder ter meio período na casa dela". Isso acontece muitas vezes com crianças que têm irmãos, que vão prá escola e outro meio período ficam em casa e então a criança fica desejosa de partilhar a casa também. São questões maiores que a creche. A gente também não pode querer ser bom prá todas as crianças o tempo inteiro. 
Além do período de permanência, preocupa a coordenadora a dúvida se bebês pequenos, que estão formando vínculo com o cuidador, teriam algum prejuízo quanto ao seu desenvolvimento por serem atendidos por um grupo de educadores ao invés de um único e pela mudança do ambiente.

Uma dúvida é a questão da referência com o adulto. A gente tem 4 educadoras de manhãa, 4 à tarde, no berçário, são 8 no total, para a criança de período integral, num momento de vida em que essa criança está estabelecendo o vínculo, primordialmente com a mãe, depois com alguém que cuida que, no meu entender, a minha linha de trabalho é a psicanálise, esse vínculo é muito importante, é constitutivo na formação da personalidade. Me preocupa sair desse vínculo, seja em casa com a mãe, com a avó, ou com uma babá, ou irmã mais velha e diversificar isso para 8 pessoas cuidando. Isso interrompe um pouco o processo de constituição da personalidade. (...) Para o bebê pequenininho, tem essa questão que ele chega e adoece imediatamente. Acho que não só adoece pelo número de vírus que a instituição acaba tendo, mas também pela fragilidade que ele passa a ter, por ter saído de casa. Essa é uma das perguntas mais delicadas, porque não é muito claro nem para mim. Hoje em dia, eu avalio caso a caso. Estou falando pequenininho, como a gente recebe bebês de 4, 5 meses, quando termina a licença maternidade, realmente eu tenho dúvida, tive dúvidas muito pessoais, inclusive quando chegou a minha vez de pôr o meu bebê.

Essa preocupação, conforme a própria coordenadora explica, fundamenta-se em estudos da área da psicologia, no caso, a psicanálise. A teoria psicanalítica é uma teoria do desenvolvimento, segundo a qual se pressupõe que a personalidade de cada pessoa é resultado de suas experiências na infância, estando já bem formada no início da idade escolar (por volta dos 7 anos de idade) (Harrison, 1975). A teoria psicanalítica lançou as bases para a compreensão da importância da qualidade dos cuidados paternos nos primeiros anos de vida das crianças, para sua saúde mental.

A partir dela, diversos autores desenvolveram pesquisas sobre o tema, sendo clássico o trabalho de Bowlby (1966), realizado no início de 1950, a pedido da Organização Mundial da Saúde. Em seus estudos, concluiu que a privação prolongada de cuidados maternos podia causar efeitos graves e profundos no caráter de crianças pequenas, os quais poderiam durar por toda a vida. Entretanto, esses estudos foram realizados em situações nas quais as crianças deixavam de ter qualquer contato com a mãe, como orfanatos, ou estes eram reduzidos a um mínimo, como no caso de internação hospitalar prolongada, com visitas breves e esporádicas. Além disso, a qualidade da 
atenção prestada a essas crianças era precária, particularmente no aspecto afetivo.

Ainda assim, esse e outros estudos que chegaram a conclusões semelhantes, como o Primeiro ano de vida de René A. Spitz e Meninos sem lar de Anna Freud, trouxeram grande impacto científico e social, contribuindo fortemente para a reorientação do cuidado institucional à criança. Assim, conforme Rossetti-Ferreira, Amorim e Vitória (1994)

"a concepção que prevalece em nossa sociedade é a de que o único cuidado capaz de prover condições adequadas ao desenvolvimento do bebê é aquele provido pela mãe no contexto da família. Assume-se o modelo de criação na família nuclear, constituída por mãe, pai, filhos e parentes mais próximos, como "natural", isto é, requerido por características próprias do ser humano. Contextos de desenvolvimento diversos, como o cuidado coletivo de crianças pequenas em creche, são encarados como "mal necessário", por constituírem um risco ao desenvolvimento sadio da criança e aceitáveis apenas naqueles casos em que a mãe ou a família não tem condições de criar o filho em casa."

Entretanto, Ghedini (1995) afirma que

"No passado recente, era corrente supor que múltiplas relações afetivas teriam um impacto negativo em crianças pequenas. Ao contrário, vimos que, nas experiências educativas desenvolvidas nas creches, as crianças sabem lidar, sem conflito ou ansiedade, com muitos contatos e relações afetivas, e que os laços de afeição e amor que assim estabelecem exercem nelas um efeito positivo. (...) Isso só é possível quando há um 'veículo' afetivo estável, ou seja, quando as pessoas com quem a criança se sente emocionalmente próxima não tenham atitudes conflitantes nem de competição entre si, quando seus papéis e funções estejam solidamente determinados e sejam reconhecidos e reconhecíveis pelas próprias crianças".

Mantovani, Terzi (1998) discorrem sobre duas ordens de motivos que negam os temores de que a creche cause traumas da separação. Inicialmente, explicam que a literatura que vem sendo classicamente utilizada fala de separações totais (dia e noite), imprevistas, que acontecem sem preparo, inserindo a criança em um ambiente estranho (hospitais e orfanatos) sem figuras adultas estáveis de referência e ocorrem fatos desagradáveis e amedrontadores para as crianças (cuidados médicos, refeições forçadas, ausência de interações lúdicas). Acrescentam que as pesquisas realizadas nos EUA e Europa a respeito de efeitos da creche sobre os comportamentos sócio-emotivos (apego à mãe, dependência-autonomia, tolerância à frustração, agressividade, comportamento social com o adulto e com outras crianças) não mostram diferenças significativas entre crianças educadas em família e 
crianças provenientes de creche.

A respeito das variáveis significativas para a experiência da criança nos primeiros anos de vida, Mantovani e Terzi (1998) expõem a regularidade nos ritmos de vida como uma das mais importantes, associada ao grau de satisfação que a mãe sente pela escolha realizada quanto ao cuidado da criança. Nesse sentido, "é melhor a creche, mesmo que por muitas horas, com rotinas certas, regulares e previsíveis com as figuras familiares, do que um pouco de mãe, um pouco de avó e um pouco de babá, de forma irregular" (Mantovani, Terzi, 1998).

$\mathrm{Na}$ entrevista, não fica claro se a coordenadora desconhece as investigações recentes ou se, apesar de conhecer, questiona-as, pois ela fala em resultados futuros, na vida adulta.

A questão da divisão constante de um espaço coletivo todo o tempo é apontada como um problema em potencial, que dificultaria à criança desfrutar de algo pessoal, individual. Perguntamos em que medida a necessidade do espaço individual é natural ou é socialmente construída? Esta visão, parecenos, fundamenta-se na psicologia e desconsidera conhecimentos da antropologia, da história, da sociologia.

De qualquer forma, vivemos numa sociedade onde os bens são muito mais privativos do que coletivos, inclusive confundindo-se o que é público como aquilo que pertence ao governo.

Quanto à preocupação de que a criança tem que dividir o adulto com as outras crianças, em casa a mãe também não está exclusivamente disponível para a criança, ela tem outras e muitas tarefas a cumprir. Na creche, embora o adulto divida a atenção com várias crianças, tem sua atividade toda dirigida a elas, não há outras tarefas domésticas a cumprir.

Nas entrevistas com as coordenadoras, houve repetidas menções quanto à demasiada permanência das crianças na creche: o período integral é questionado em relação a privar a criança de possibilidades que só existiriam em casa. Uma questão que elas não levantam é que, se as crianças ficam tão pouco tempo com a família, talvez haja mesmo um problema com relação à 
interação no lar, uma falta de tempo suficiente para construir as relações no ambiente familiar.

Outra questão relativa ao tempo longo de permanência na creche referese a que se a criança precisa de tempo livre e individualizado e a creche não pode oferecer, então ela deveria ficar mais tempo em casa para poder atender essa necessidade? Será que isso é mesmo inviável na creche? 


\section{PARA AS EDUCADORAS}

\section{- Funções da creche}

\section{Promover o bem-estar da criança}

No discurso das educadoras, evidenciou-se que a concepção acerca da função da creche está centrada na parte pedagógica, que abrange conteúdos disciplinares, tal como na escola. Mas, como condição para que a função pedagógica se efetive, ela deve cumprir a função de promover o bem-estar da criança. Tal visão tem relação direta com a concepção acerca do papel das educadoras.

O princípio da creche é o bem-estar da criança, tudo é centrado na criança. A troca, a alimentação, o sono, como ambiente confortável para a criança. Ela estando limpa, bem alimentada, descansada, você está criando um ambiente facilitador para que você possa propor um outro ambiente de desenvolvimento cognitivo. A nossa parte pedagógica, de linguagem, matemática, é facilitada pelo bem-estar que ela está, então ela está disponivel para aprender.

Proporcionar bem-estar é como as educadoras expressam sua concepção sobre cuidado da criança na creche.

A inserção das creches junto à Coseas, um órgão de assistência social da Universidade, torna confusa a definição da sua função: embora sendo instituições educativas, não se vinculam a um órgão da educação e sim da assistência social, configurando-se como prestação de serviço da área social, e não incorporando a necessária dimensão educativa, ocasionando, por exemplo, que essas trabalhadoras não sejam consideradas professoras. Depreende-se aqui um sentimento de desvalorização por esse fato.

A creche é o que? É uma prestação de serviço. É uma prestação de serviço que está aonde? Não está na educação, está na assistência social... por estar na assistência social, é uma prestação de serviço, não tem aquela visão de educação. Existe um trabalho educacional, de um valor muito bom, tem profissionais competentes, mas, ao mesmo tempo, essa creche, esse órgão de educação ele não está em lugar nenhum. Ele não está inserido nem na educação, não é da educação, está na assistência social, mas com outro serviço, é meio confuso.

A gente tem claro que nós somos prestação de serviços na universidade, somos secundárias sim, porque à vista do reitor nós não somos professores, é uma prestação de serviços. 
Há questões do contexto histórico e social que fundamentaram as concepções sobre a creche. Rosemberg (2000) explica que as creches universitárias surgiram visando atender o direito das mães trabalhadoras, não tendo como mote principal a visão de espaço educativo. Com isso, alocaram-se no setor de benefícios, não vindo caracterizar-se como unidade universitária com funções indissociáveis de ensino, pesquisa e extensão. Essa origem tem consonância com as características mais gerais da luta por creches que teve lugar na sociedade em geral, na mesma época. Além disso, no que tange à missão da universidade, qual seja ensino e educação de adultos, as creches representam uma contradição, pois visam a educação infantil.

No entanto, há um equívoco na compreensão de que por serem prestação de serviço descaracteriza-se a função educativa das creches: a educação é uma prestação de serviço. Conforme Bondioli e Mantovani (1998)

"O discurso sobre a creche, enquanto serviço social, coloca-se no interior daquele discurso mais geral, dos modelos do welfare state, isto é, no interior de projetos de política social que tendem a garantir a todos os cidadãos um nível mínimo de assistência através da oferta de prestação de serviços (...) a creche 'moderna' (...) nasce como serviço em resposta às necessidades e aos direitos da mulher que trabalha, como garantia de ocupação extradoméstica, cuja tendência é eliminar a discriminação da mulher, enquanto mãe, e sua conseqüente possível exclusão ou marginalização no mercado de trabalho".

As autoras completam que, numa visão mais atual sobre a creche como um direito da criança, à medida que se torna uma instituição pertencente à educação, mantém-se a idéia básica da creche enquanto instituição capaz de fornecer serviços como também de "mediar e redistribuir prestações provenientes do poder público".

Contudo, a percepção das educadoras é bastante relevante para outra discussão. Palhares e Martinez (2000) lembram que "o caminho apontado pela equipe técnica responsável pela educação infantil no MEC, em 1994, era o de buscar superar a dicotomia da educação/assistência incentivando estratégias de articulação de diversos setores ou instituições comprometidas com a Educação Infantil". Assim, embora esteja previsto que as creches devam vincular-se ao órgão responsável pelo ensino no município, "uma estruturação escolar, por si só, não dá conta da operacionalização de modelos de atendimento à criança de 0 a 6 anos, com o caráter multifacetado que 
pressuporia a integração de ações de Saúde, Educação, Assistência Social e Cultura" (Nascimento, 2000).

Conforme se apresenta a seguir, as educadoras têm conhecimento de que a visão contemporânea sobre a creche foi construída historicamente e a carga dessa história é sentida como um peso, um entrave ao reconhecimento e à realização de sua função educativa.

A palavra creche é um pouco pejorativo, é difícil de derrubar isso. A creche foi criada porque as mães precisavam trabalhar na época, 100 anos atrás, $e$ tinha que ter um local pra deixar seu filho só prá ser assistido fisicamente.

O nome creche, essa denominação, que não deixe assim: quando a criança vai para lá como um lugar que ela tem para ficar, porque os adultos que deveriam ficar com ela não têm disponibilidade.

A conotação pejorativa do termo creche refere-se a uma realidade concreta em que a forma mais difundida sobre essa proposta de atendimento infantil baseia-se numa postura assistencialista, caritativa, visando a população mais desfavorecida socialmente, centrada na guarda ou abrigo da criança e nas atividades de saúde, higiene e alimentação. Os enfoques compensatório e médico-higienista, esteios desse atendimento, levaram a uma série de distorções, culminando em propostas cuja tônica, dentre outros sérios problemas, é a falta de capacitação das pessoas que cuidam das crianças. Ainda hoje, a concepção corrente estigmatizadora é de que a creche, ao invés de uma solução de boa qualidade para atender a criança pequena, seja um "mal necessário". Na verdade, grande parte das instituições ainda tem esse caráter: em outubro de 2000, um jornal de grande circulação no Estado de São Paulo, apresentou como uma das manchetes "Pesquisa mostra má qualidade de creches", trazendo dados de uma investigação nacional realizada pelo Ministério da Previdência e Assistência Social em parceria com o Instituto de Estudos Especiais da Pontifícia Universidade Católica de São Paulo, em 1999. Foram destacados os seguintes problemas: educadores recebendo baixos salários e com escolaridade insuficiente (no Município de São Paulo, apenas $14,7 \%$ dos profissionais das creches públicas concluíram o ensino médio); instalações precárias que não garantem às crianças condições mínimas de uso e baixo investimento em material pedagógico. 
Conforme Rosemberg, Campos e Pinto (1985), "o assistencialismo que predominou por longo tempo nas creches nem sempre deu a devida importância à questão da qualidade dos serviços prestados". E ainda mais, "nesse caso, os serviços são considerados favores oferecidos à população, e os pais não têm direito a qualquer controle ou intervenção sobre o que acontece com seus filhos na creche". Podemos afirmar que essa realidade se revela semelhante ao que ocorre em outras esferas e serviços da área social: na saúde, nos demais níveis da educação.

As creches desta pesquisa divergem em absoluto dessa situação alarmante de um grande número de creches brasileiras, pois vêm construindo seu trabalho numa perspectiva totalmente diversa. As discrepâncias entre as realidades que convivem no mesmo tempo (atual) foram representadas como um emaranhado de fios, evocando a idéia de confusão sobre a função da creche, presente no imaginário da população.

Assim, identificam como uma concepção corrente de creche a de que se trata de uma solução para atender a criança cujos pais não podem cumprir seu papel como "os adultos que deveriam ficar com ela [a criança]". A educadora expressa nessa frase uma representação social sobre o cuidado da criança como função exclusiva ou primordial da família, especificamente mãe e pai. Isso pode ser comprovado pelo sentimento de culpa muito freqüente nas mães, devido à "noção de que confiar uma criança à creche significa de certa forma abandoná-la" (Rosemberg, Campos e Pinto, 1985), também fruto da tradicional divisão sexual de papéis - pai provedor, mãe cuidadora do lar e dos filhos.

Ao representar a história da creche se edificando no tempo, a educadora afirmou que esta foi se modificando, com erros e acertos, mas não perdeu completamente a base sobre a qual surgiu: a assistencial, de prestar cuidados.

A creche deve ter surgido de algum lugar, alguém pensou de estar pelo menos só cuidando, assistencialista mesmo, e foi crescendo... não deixando cair no esquecimento as coisas que foram observadas, analisadas, que deram certo prá creche crescer. A creche evoluiu bastante, em cada cor tem uma fase da creche. Esse pedacinho foram aqueles pedacinhos que foram aproveitados e que foram amarrados para a base não deixar cair. $E$ cada época que a creche foi passando, eu fui reforçando o primeiro pedacinho, que está aparecendo em todos, até chegar aqui, onde uniu todos, e a gente tem que pensar se deu certo, se está dando certo, a gente não pode parar por aí. 
É possível identificar nas entrevistas e mesmo em trabalhos científicos como o de Dutoit (1995), que o conhecimento sobre a história da creche foi obtido a partir da coordenação, durante o processo de formação. $\mathrm{Na}$ construção desse conhecimento, evidencia-se que o cuidado, para as educadoras, foi incorporado como sinônimo de assistencialismo ("pelo menos só cuidando, assistencialista mesmo"). Embora afirmando que cuidar mantémse como função da creche, parece não haver uma discussão sobre o modelo de cuidado presente em cada momento da história da creche e, mais ainda, que todo modelo de atendimento sempre é educativo, como afirma Kulhmann $\operatorname{Jr}(1991)$.

Evidencia-se que a educadora reconhece na sua creche um exemplo da maior possibilidade que existe de tratar a educação infantil com compromisso, com profundidade: ao longo do tempo, "ela vai se recheando de outras cores, de outras possibilidades". Deixa de ser vista como resposta pontual e passa a ser defendida como um direito, além de um equipamento que deve estar comprometido com a educação infantil. Isso expressa um acúmulo de conhecimento, de tecnologia, de formas de pensar criança e de fazer esse cotidiano diferente, de formar os educadores de outra maneira. Também reconhece claramente que a assistência está lá, no dia-a-dia, em inúmeros momentos e ações que nunca vão deixar de acontecer: as crianças não poderão deixar de ser alimentadas, higienizadas, acolhidas.

\section{- A vida da criança na creche}

A vida da criança na creche reúne aspectos relativos a como as educadoras atendem/lidam com as crianças e como estas reagem, se apresentam no cotidiano.

\section{A relação da criança com a creche}

As dúvidas apontadas pelas coordenadoras sobre o longo período de permanência diária das crianças na creche foram também citadas pelas educadoras mas estas últimas concluem que, para as crianças, não se trata de um problema. Ao contrário, elas gostam de estar na creche tanto que, muitas 
vezes, relutam ir embora no horário da saída e não gostam de perder dias de creche.

A gente se questiona muito. Uma criança fica às vezes 10,11 horas dentro da creche. E a gente fala "é tão cansativo, a casa é tão gostosa, acolhedora" mas a criança necessita desse espaço e briga prá ficar ali. No período da greve, teve crianças que ficaram muito bravas porque não estavam na creche, porque é um lugar que elas gostam. No final do dia, a mãe vem buscar e tem criança chorando que quer ficar, e é seis e meia da tarde, e ela está ali desde as sete da manhã.

Tem criança que quando a gente fala "a creche está em greve", ela [fala] "mas eu não estou”.

Até mesmo um problema apontado - a falta de brinquedos - não é sentido assim pelas crianças pois elas "usam a imaginação" e se divertem.

E desses brinquedos que eles têm, eles criam. Eles fazem brincadeiras super legais constróem castelos, constróem túneis, com materiais, mas não o brinquedo, de verdade.

O comportamento das crianças contradiz a representação das educadoras acerca do lar como um ambiente melhor para a criança ("a casa é tão gostosa, acolhedora"), como também sua reclamação sobre a escassez de brinquedos na creche.

A menção à situação de greve deve-se a que, durante a realização desta investigação, ocorreu uma greve na universidade, incluindo as creches, que durou cerca de 50 dias. $O$ impacto da greve sobre as crianças é manifestado pela "braveza" percebida pelas educadoras. É importante atentar que todo o investimento para que a criança crie vínculo com a creche resultou positivo e que a expressão de desagrado das crianças mostra como elas se sentem à parte desse "andar da carruagem" e são atropeladas por uma decisão da qual não participam e para a qual não está organizado um processo de adaptação. Parece que não é percebido que, quando a criança responde que não está em greve, ela pode estar manifestando um sentimento de traição. Assim, essa é uma situação que também precisa ser melhor compreendida e cuidada.

Ao observarem as crianças em diversas situações, as educadoras identificam que elas estão se desenvolvendo, tornando-se independentes, cientes de seus direitos, e atribuem tais progressos à experiência de freqüentar a creche. 
As pessoas que estão de fora começam a perceber toda essa independência dele, porque talvez se ele só estivesse na minha casa eu estaria dando comida na boca com babadorzinho.

No momento de grupo, momentos dos jogos, da fantasia, com os livros, o desenvolvimento da auto-imagem, da linguagem, quando eles usam a boneca porque eles tão mudando de pessoa, eles se colocam como a mãe, eles deixam de ser a filha prá ser a mãe, e eles levam esse bebê para o pátio, cuidam, dão comida, levam prá passear, dão banho, a responsabilidade com aquele bebê.

Brincando com os priminhos, ele disse "vai prá lá, aqui é meu lugar vai prá lá”. Quer dizer, essa socialização com outras crianças, saber qual o espaço dele. É muito importante, e é na creche que a criança adquire.

$\mathrm{Na}$ creche, ocorrem interações entre as crianças do mesmo grupo e também dos diferentes grupos, pois há momentos em que elas se misturam no mesmo espaço, em atividades comuns. Sempre no início da manhã ou da tarde, elas se encontram nos ateliês: dirigem-se, segundo sua escolha, para uma das áreas onde estão organizadas atividades ou brincadeiras, independentemente de estarem com seu grupo ou sua educadora.

É um momento bem legal: a interação de bebê com criança grande, que acontece no nosso ateliê, é uma coisa que dá certo, a gente foi fazendo experiência e dá certo.

Uma característica da situação de creche é que as crianças formam vínculos umas com as outras

Quando a criança chega, ela se apega à outra criança. Às vezes, elas têm um certo vínculo e gostam de estar com aquela criança. É super importante.

Entretanto, as interações podem representar algumas ameaças:

Mas tem dois lados aí: ao mesmo tempo que eu tenho um coleguinha, eu vou ter que dividir o que eu tenho.

As educadoras relatam aspectos muito concretos de sua vivência, observados no dia-a-dia e consideram pontos importantes relativos à vivência do grupo de crianças: a interação satisfatória de crianças de diferentes idades, as relações de amizade entre crianças contemporâneas e os encontros dos diferentes interesses infantis. Pode-se dizer que constatam empiricamente produtos da aprendizagem das crianças acerca das relações interpessoais estabelecidas entre elas. 
Um dos aspectos estruturais mais característico que diferencia a creche do ambiente domiciliar é o encontro cotidiano de várias crianças da mesma idade. Resgatando resultados de diversas investigações, Musatti (1998) conclui que há consistência nos relacionamentos infantis à medida que as crianças vão se tornando familiares umas às outras. Diz a autora:

"Elas entrelaçam atividades, jogos e relações afetivas de acordo com processos de sociabilidade que possuem tanto aspectos de semelhança quanto de diversidade com aqueles que podem ser identificados na expressão de sociabilidade com adultos. Além disso, parece que as crianças em idade de creche desenvolveram uma alta e sofisticada capacidade de produzir estratégias interativas diferentes, em função do parceiro do qual aprendem a conhecer precocemente os estilos interativos e com o qual entrelaçam relações diferentes".

Em nossa realidade, também dispomos de pesquisa que confirma ser a interação entre crianças altamente interessante para o desenvolvimento infantil, enfocando experiências de organização de grupos etários mistos em creches ${ }^{\natural}$ (Ignácio, 1995).

\section{Como atender a criança na creche}

Visando promover o bem-estar da criança na creche, as educadoras realizam uma série de ações que constituem intervenções educativas e de cuidado, e visam favorecer o desenvolvimento infantil.

As ações não são iguais para todas as crianças, pois cada uma tem suas demandas. Um fator que as diferencia é a idade, havendo uma progressiva autonomia, conforme a idade aumenta.

O que difere bastante é a faixa etária. Quando a criança é menor, ela necessita mais, você tem que receber, pegar no colo mesmo, não é só porque anda não tem que ter esse carinho, essa afinidade. E quando eles são maiores, eles chegam lá de manhã e já querem brincar. Chegam "tchau, mãe, tchau", e nem prá você educadora olham, eu cobro "ei, nem falou com a educadora? bom dia", "bom dia", e pronto, vai brincar. Então na faixa etária menor é muito importante, e quando eles são maiores já tem mais independência, já fica mais light mesmo.

Nas situações cotidianas, há que ajudar a criança no aprendizado sobre compartilhar, manter ou melhorar a auto-estima, e desenvolver autonomia e responsabilidade.

\footnotetext{
${ }^{2}$ As creches mantidas na comunidade "Monte Azul", nas quais o cuidado é fundamentado na Antroposofia de Rudolf Steiner.
} 
E "compartilhar", que aparece muito nos livros, nos brinquedos no módulo 1 , e na disputa do pátio, das caixas de brinquedo. E é difícil esse compartilhar. $O$ quanto a gente tem trabalhado esse compartilhar quando eles chegam na creche, no ateliê, na acolhida deles, na hora que eles vão embora.

Me preocupa bastante trabalhar a auto estima da criança. Estar valorizando o desenho que a criança faz. Por exemplo, se ela mora na favela ela vai desenhar um barraco mesmo. Porque é a casa dela, é importante a gente estar valorizando, reforçar a auto-estima da criança.

Os combinados começam a aparecer de verdade, com significado prá eles, no segundo semestre, no G2, "lembra do nosso combinado?" eles conseguem falar "lembro", eles estão tomando propriedade disso, estão criando autonomia, ficando independentes e tomando um pouco de responsabilidade.

A preocupação de trabalhar com a criança o que significa compartilhar, cooperar, respeitar acordos ou combinados, também é uma forma de promover sua auto-estima.

"Dar oportunidade à criança de participar das discussões, decisões, escolhas, cooperar, ter iniciativa, somar esforços, negociar, comprometer-se e avaliar os resultados de seus esforços são meios para promover a auto-estima infantil: esta pode ser baseada nas contribuições para o grupo a para a qualidade dos resultados e esforços do grupo". (CHARD, S.C. The project approach. Book two)

Mostra também uma concepção de que o crescimento saudável não é aquele em que a pessoa é poupada de todas as dificuldades, mas sim ajudada a aprender a lidar com conflitos, porque os conflitos fazem parte da nossa realidade. Autonomia significa não só o direito de escolha, mas também a conseqüente responsabilidade.

Pode-se afirmar que as concepções de criança e de educação sofreram grandes mudanças nos últimos anos, sendo recente essa preocupação com o desenvolvimento da auto-estima e autonomia, bem como o respeito às opiniões infantis. Ariès (1981) relata que, na sociedade medieval, não existia o sentimento de infância, a consciência da particularidade infantil. Assim que a criança tinha condições de viver sem a solicitude constante da mãe ou da ama, ela ingressava na sociedade dos adultos e não se distinguia mais deles. A partir do século XIV, a arte, a iconografia e a religião expressavam a personalidade que então se admitia existir nas crianças. O novo sentimento de infância que surgiu foi chamado pelo autor de "paparicação" e tornou a criança ingênua, gentil e graciosa, uma fonte de distração e de relaxamento para o 
adulto. Depois, surgiu a preocupação com a formação moral desencadeada pelos moralistas e os educadores do século XVII. E, no século $X X$, os estudos da psicologia vieram constituir a base para "a nova definição da primeira infância, das atividades e competências dessa idade" (Chamboredon e Prèvot, 1986).

São várias as situações em que as crianças são estimuladas a exercitar a autonomia. São-lhe oferecidas opções concretas, com garantia de que sua escolha será respeitada: o bolo de aniversário, os ateliês e até mesmo a preferência por uma educadora.

Na semana passada, nós fomos escolher um bolo e a técnica da nutrição deu uma lista prá gente escolher o que ela poderia estar preparando naquele dia. Tinha bolo de limão, bolo de fubá, bolo mármore. Eu lendo prá eles, uma criança falou: "eu não gosto de nenhum desses bolos, eu quero bolo de laranja" o outro falou: "eu também quero um bolo de laranja que eu gosto mais" o P. falou: "eu prefiro bolo de limão", e eles ajustaram um cardápio que era completamente diferente daquele que estava sendo proposto.

E a gente monta os ateliês prá criança estar escolhendo o que fazer naquele momento.

Desde o ano passado a gente viu no berçário que a criança também elege a pessoa, o adulto que irá fazer a adaptação dela. E a gente tem que levar em consideração, respeitar essa opinião, por menor que ela seja, não importa. A gente pode chegar e falar vamos fazer a adaptação de tal criança. Só que chega no dia, a criança bate o olho e fica com a outra. E aí? Você vai "não, é só com a gente", não, a outra educadora assume e faz a adaptação, porque a criança se identificou mais com ela. Isso tem que ser levado em consideração.

Destaca-se aqui a capacidade empática das educadoras, de identificar a necessidade e o desejo individual das crianças e responder a eles ativamente, o que pode ser característica de profissionalismo. Bondioli e Mantovani (1998) definem autonomia como "capacidade de tomar e conduzir iniciativas próprias para aquilo que diz respeito tanto ao controle do próprio corpo (comer, ir ao banheiro, vestir-se, adormecer), quanto às atividades motoras, cognitivas e lúdicas. Nesse sentido, autonomia é sinal de bem-estar psico-físico e acompanha-se de uma relação relaxada e sem ambivalência entre adulto e criança."

Um aspecto que também as preocupa é o de garantir a atenção individual dentro do coletivo. Isto foi exemplificado com uma situação entre 
uma criança e a cozinheira, destacando-se que a individualização do atendimento é importante para a criança e também para a educadora, que diz emocionar-se, denotando o grande valor que atribui a essa forma de atenção.

Tem uma criança que gosta muito de salada de fruta, e a R. falou: "eu vou fazer salada de fruta especialmente para você" e tinha um outro brincando lá. Ele registrou isso e foi no comecinho do ano. E ele gosta muito de creme de abacate, e ontem teve creme de abacate, fazia tempo que não tinha. Os pais vêem no cardápio que fica no corredor, aí ele foi lá falou " $R$., hoje tem creme de abacate?" ela falou "tem". E ele "então quando for na hora da sobremesa depois do almoço, você fala prá todo mundo que é especialmente prá mim", até emociona, por conta do tempo. Já faz quase quatro meses. Tem essa relação também muito próxima que tem um monte de coisa positiva.

A festa de aniversário da criança é outro exemplo da individualização do cuidado.

Tem o aniversário. $O$ dia do aniversário da criança é comemorado na creche. As crianças maiores escolhem o bolo, o pai e a mãe vêm, se a mãe pode, vem a avó. Canta parabéns para a criança e o grupo, é um momento muito legal, muito gostoso, e a criança curte mesmo.

Esses exemplos validam que a proposta de atendimento está sendo implementada, que os princípios de respeito às escolhas, de promoção da autonomia e de individualização do cuidado não estão presentes só no discurso mas também na operacionalização das ações de cuidado e educação. Embora não tenha surgido essa definição, esses exemplos também podem ser compreendidos como caracterizando a creche enquanto "ambiente de vida num contexto educativo". Essa definição vem sendo adotada na Itália para designar a creche e é bastante mais abrangente do que a de um espaço pedagógico.

Outro aspecto fundamental é a compreensão acerca de como deve ser a relação da educadora com a criança: sem autoritarismo ou imposições.

A justificativa é um fator predominante com relação aos limites às regras, porque tudo a gente sabe justificar e argumentar o porque. Não é "não, $e$ pronto". Existem momentos que a criança pode decidir o que fazer. Há momentos que não, que eu tenho o cuidado de planejar, de estudar, e de trazer isso para o grupo. O momento que eu planejei e que eu pensei em todos, você acaba justificando porque ela tem que fazer aquilo, porque seria legal ela estudar junto.

Eu posso sentar no chão e brincar com a criança, estar na altura dela, mas ela vai perceber que eu posso ser o adulto e a criança ao mesmo tempo. A gente discutiu bastante também a autoridade e o autoritarismo. Eu sou autoridade ali. Porque senão a criança se perde naquele espaço, se eu não 
der um limite para ela, que é diferente do autoritarismo: "não vai fazer porque eu não quero que você faça". Não, existem critérios, regras, para não fazer isso. E a criança percebe bem até onde ela pode explorar a gente.

Quanto à creche como um contexto que promove a autonomia da criança, a educadora manifesta o desejo de que o processo educativo se torne uma realidade capaz de formar e manter a consciência de cidadania das crianças.

A creche como o ambiente que dá autonomia, que dá uma consciência política para as crianças. Eu gostaria muito que isso se expandisse, que eu pudesse ver a minha a filha assim brigando pelos direitos que ela tem, sabe? E não, simplesmente, ela adquiriu isso e se perder no caminho. Eu gostaria de ver mesmo essas crianças que eu trabalho hoje, brigando no futuro por uma educação mais justa, por tudo mais justo, por uma vida mais justa, eu acho que a educação é a base de tudo.

Talvez essa fala mostre-se contraditória se, por exemplo, retomarmos a situação da greve: as crianças manifestaram-se, brigaram como podiam pelo seu direito de continuar freqüentando a creche. Mas que tipo de resposta receberam? Será que o direito só é respeitado quando já está previsto no projeto educativo? Como interpretar os imprevistos? Isto demonstra como ainda precisamos estudar muito para implementar uma proposta tão ampla.

No relato seguinte, a educadora apresenta como lidou com um problema sobre o qual ela havia comentado no encontro anterior:

Lembra que eu falei semana passada das caixas? Mudamos a rotina do meu grupo com relação a essas caixas, que eles estavam comendo correndo, para ir brincar. Tive uma conversa de roda, para eles comerem tranquiilos com calma, o que eles gostavam de comer. Acaba de almoçar, vai para a salinha, brincam lá, com as coisas que eles trazem de casa. Eles trazem brinquedos mas não têm a oportunidade de brincar na salinha deles, só com os amigos. Ou divide com a creche inteira, ou guarda. Encontramos o momento. Dividem com o amigo da salinha, quer ficar no canto sozinho fica. Enquanto isso, a educadora da tarde vai chegando e vai chamando aqueles que estão com sono. Quer dizer, nem eles saíram para disputar a caixa, nem fizeram aquela construção de casa, que eles tinham feito. É lógico, depois que você constrói uma casa com uma caixa, não vai querer sair para dormir. Se a gente tem essa percepção, a gente pode pensar e mudar direções, para o bem-estar, para melhorar.

Para atender bem as crianças, as educadoras buscam formas de superar as dificuldades que encontram, como a escassez de brinquedos e os problemas do espaço físico, a fim de tornar a creche um local prazeroso. 
A gente vê no nosso relato, o quanto são grandes as dificuldades, e quanto a gente tem superado essas dificuldades e transformado esse ambiente, prá criança gostar da creche, gostar desse espaço

A gente garante essas brincadeiras todos os dias, a areia, a história, as balanças, as motocas.

No comecinho do ano, quando as crianças chegam, a gente fica preocupada, tem pouco material, pouco brinquedo, e a gente tenta fazer alguma coisa para as crianças poderem brincar. Esse brinquedo é o chocalho, que a gente monta lá no berçário, uma coisa bem legal, que as crianças gostam bastante.

Houve várias referências à falta de brinquedos na creche mas, na verdade, todas elas dispõem de considerável volume de brinquedos. O que é importante evidenciar aqui é o trabalho das educadoras relacionado à organização do ambiente, das atividades e das rotinas.

Intimamente relacionada ao bem-estar, destacou-se a preocupação com a alimentação.

A alimentação aparece tanto no berçário quanto nos maiores. Quando o bebê não mama, as educadoras ficam desesperadas porque o bebê não comeu. E, no módulo 2, que as crianças deixam de comer prá brincar no pátio, as educadoras se preocupam do mesmo jeito porque elas estão deixando de comer também. É uma coisa que permeia todos os grupos, independente da idade.

$\mathrm{Na}$ situação de atender crianças portadoras de deficiência, no caso uma criança com profundos comprometimentos físico e mental, as educadoras perceberam a possibilidade de influenciar o seu desenvolvimento ainda que não realizando com ela atividades propriamente pedagógicas.

E quando tem que passar essa afetividade, essa confiança, essa relação, prá uma criança de uma outra cultura, ou crianças com necessidades especiais. Anos atrás, a gente não imaginava que poderia receber uma criança em cadeira de rodas, deficiente física e mental. E, talvez, há uns anos seria um bicho de 7 cabeças "meu deus, aqui? Não tem condições de fazer um trabalho com a criança". A N. não tem um trabalho propriamente pedagógico mas em todo o desenvolvimento dela, está ali, é visível.

Em todo o exposto, pode-se afirmar que atender a criança implica num rol de ações de cuidado e educação. Há dois momentos que foram particularmente destacados, o período de adaptação e a recepção diária das crianças, como sendo momentos que precisam ser muito bem trabalhados para que a criança fique bem na creche. 
Assim, as intervenções para promover o bem-estar da criança iniciamse no período de adaptação. Trazer a mãe para participar desse período, deixar a criança com seu objeto de apego, estabelecer uma educadora para referência, promover vínculo afetivo, são exemplos de como atendê-la.

A mãe fica tanto tempo dentro da creche, numa adaptação, para ver $e$ conhecer o trabalho, como é feita a adaptação. Não é assim: a criança está chorando, [tudo bem], ela acostuma, ela fica. Não é isso, não é um depósito, há uma ligação afetiva, e a gente está querendo criar esse vínculo. E a mãe fica o tempo que ela necessita, que ela tem disponível, e aumenta a confiança da criança.

É fundamental que a criança tenha na creche, num processo de adaptação, o objeto de apego. É a referência da casa dela. Eu posso até dar um outro brinquedo, mas o que ela trouxe de casa "é o único laço que eu tenho, entre eu e minha casa e minha família". Essa discussão a gente faz também, na creche, a importância do objeto de apego.

A gente vive isso no berçário muito, a gente percebeu o seguinte: se uma pessoa não tivesse uma relação direta com a criança, não fosse a referência dela, o processo de adaptação ficava muito difícil. E uma pessoa só não ia agüentar, porque senão ela não podia sair prá almoçar, ela não podia ir ao banheiro, então a gente passou a trabalhar com duas referências para criança. Com duas pessoas com a criança o tempo todo, fica mais fácil a relação criança-mãe-educador.

A ida da criança para a creche depende de uma entrega não só da criança, mas de toda a família, que precisa estar segura para fazer tal entrega. Um elemento que é sempre apontado como responsável por essa dificuldade é a confiança. Mas há que se considerar também o problema da rotina, quer dizer, mudar a rotina é algo que também exige adaptação. Pode ser necessário despertar mais cedo pela manhã, para preparar a criança, reorganizar todas as atividades, além de lidar com a separação propriamente.

Eu tenho uma filha de nove meses que começou a ir para a creche agora. Ela era acostumada a dormir até nove horas, nove e meia, dez horas da manhã. Agora, quinze para as seis eu estou colocando fralda. Eu sofro bastante com isso, mas também eu acho melhor a criança estar na creche do que ficar em casa. Quando eu chego na creche, a primeira coisa que as meninas perguntam: "M., ela dormiu no carro? Que horas você tirou ela da cama?", ela tem o cuidado de perguntar que hora que ela saiu da cama. Agora faço diferente: pego ela dormindo, coloco na cadeirinha dormindo, ela vai dormindo até a creche. Chega na creche, ela abre o olho e pronto, vai brincar com os amiguinhos, depois toma um leite...

O destaque no vocábulo cuidado na citação anterior foi para ressaltar a fala sobre uma ação de cuidado para com a criança e para com a mãe, que 
mostrou sentir-se mais segura em deixar a criança com alguém que manifesta tal preocupação-cuidado. Tendo em vista que as educadoras crêem que a segurança dos pais favorece a adaptação da criança, essa atenção reverte em benefício do próprio trabalho:

A criança percebe a insegurança do pai, claro que atrapalha um pouco sim. Quando os pais estão mais tranqüilos é mais tranqüila a adaptação.

Foi lembrado também que a companhia do irmão ajuda a criança na adaptação.

A D., que é irmã dessa R., fala para mim: "olha, eu estou no berçário um pouquinho com a R.". A gente tem que colocar um pouco de limite "agora está na hora da R. ficar sozinha", mas isso ajuda.

É possível identificar quando a criança está adaptada à creche:

Se a criança está comendo, dormindo, brincando, o próprio estado dela na creche está mostrando que ela está adaptada, como ela está bem.

O momento da chegada da criança na creche apareceu como muito significativo, muito importante. É esperado que a criança proteste para se despedir dos pais e até mesmo reaja à eminente separação deles.

Muitas vezes a criança vem tranqüila. No caminho que sobe para a creche, ela começa a chorar porque ela reconhece o trajeto. Você abre a porta ela para, quer voltar prá trás, ela reconhece que vai ficar e vai passar por essa separação.

Quando a mãe diz "você vai ficar na creche" aquele nome já indica que a mãe vai deixar, vai haver essa separação. Tanto é que quando ela falava creche o choro aumentava: quer dizer é a hora da separação. Mas tem a relação com os educadores, ela vai mostrando os objetos e vai ficando mais tranqüilo.

A despedida é assim mesmo. Ela vai chorar na hora que for ficar com a educadora, mas ela vai ficar bem, a senhora liga prá ver como é que está, se chegar chorando até a tarde, ninguém vai deixar, eles chamam.

Para a criança, a chegada marca uma transição: ela está deixando de ser cuidada pela família, e vai ser cuidada pelas educadoras. Na creche, ela tem um grupo que apresenta situações de prazer e também de conflito. Nem sempre a rotina prevista está de acordo com a sua vontade. Assim, há várias razões para que a criança proteste nesse momento, ainda que goste de ficar na creche e que fique bem após a saída dos pais. É importante notar que há uma preocupação e uma série de cuidados para acolher a criança nesse 
momento: receber carinhosamente, oferecer atividades diversificadas para ela escolher, permitir que continue o sono.

A criança tem que ter claro como ela é bem recebida, que ela está sendo esperada.

A recepção da criança, quando ela chega na creche, às vezes fica chorosa, tem que acolher, pegar no colo, levar prá passear um pouco pela creche.

A chegada, a recepção, tem que ser muito legal, muito tranqüila, afetuosa, todos os dias, durante o ano inteiro. Não só porque é janeiro, só porque voltou das férias, isso é o ano inteiro. As propostas para esse momento da chegada são os ateliês, elas têm a escolha, podem fazer a atividade como elas queiram, na sala de fantasia, nos jogos, nas artes visuais. É um momento marcante prá eles.

Na hora que ela está chegando, ela está tão agitadinha que o mais importante naquele momento é que ela fique bem. A gente vendo que ela está com sono, tem um cantinho com os colchões, e ali a criança senta, com os brinquedinhos, com os livrinhos e ali já vai dando assim um jeitinho prá ela ir se aconchegando. Depois, vai para o berçário dormir. Primeiro a gente quer que ela fique tranqüila e havendo necessidade ela vai dormir, independente do horário.

Além disso, ressaltam a importância do ritual de despedida, pois sabem que a criança precisa ter segurança de que a mãe ou o pai vai voltar, que ela precisa ser informada sobre o que vai lhe acontecer.

A gente vivenciou isso no berçário. De uma mãe sair escondida, e a criança sofria o tempo inteiro aí a gente chegou nela e falou: "olha, você vai ter que falar o tchau porque senão ela vai sofrer muito". E agora essa criança está melhor, porque ela sabe que a mãe vai e vai voltar...ela acabou ficando bem melhor de ouvir a mãe falar eu vou trabalhar mais eu volto.

A gente já teve muito problema, a mãe sai achando que está fazendo bem prá criança e sai escondida. E a gente já discutiu que, por mais que a criança chore é importante olhar para a mãe dela, [ouvir] "a mamãe vai trabalhar, mas depois ela volta", não estar enganando a criança. Isso vai dar uma tranqüilidade prá criança, tanto é que depois de um tempo, quando ela tem dois anos, ela vai começar a dizer mamãe foi trabalhar, mamãe foi "baiar", tem uma criança lá na creche que diz "mamãe foi ganhar dindin". Ele quer ouvir, tem necessidade de ouvir isso. "mamãe, C.?, ganhar dindin?" "É querido, ela foi trabalhar, mas ela volta". Ele já tem a resposta, mas tem a necessidade de ouvir da gente.

Que é diferente de a mãe dele desaparecer e ele ficar sem saber se ela vai voltar ou não... 


\section{- Controvérsias sobre a creche}

As educadoras reportaram problemas de espaço físico, percepções da população sobre a creche, demanda reprimida, existência de creches com atendimento precário e até a descontinuidade da proposta educativa da creche no ensino fundamental, problemas estes que concorrem contra o trabalho realizado por elas junto às crianças nas creches USP.

Com relação a possíveis prejuízos para a criança em virtude do tempo de permanência diária, uma das primeiras questões levantadas por elas na oficina, tais dúvidas são dissipadas ao perceberem as manifestações das crianças de não querer ir embora no final do dia nem faltar. Mas elas identificam que muitos pais julgam que a criança é melhor atendida por um familiar do que na creche, optando pela instituição somente na falta dessa possibilidade.

Que ela vai ficar mais confortável, em casa, com avó, com tia, do que na creche com pessoas estranhas à criança.

Essa fala traz à tona uma concepção de que a atenção na creche não supre a demanda da criança integralmente, à semelhança das coordenadoras que questionam sobre uma possível carência quanto ao atendimento da criança nesse local.

Corroborando essa percepção, uma educadora que defendeu de maneira incisiva a qualidade do atendimento na creche (USP) afirmou que prefere deixar o filho em casa, com sua mãe, quando acontece "qualquer coisa", como uma coriza.

Eu moro com a minha mãe, então qualquer coisa que o V. está, coriza alguma coisa assim, eu não levo ele prá creche. Eu não levo, eu não levo. Se está com febre então piorou, porque tem minha mãe que não trabalha. $E$ que fica ali. Outro dia eu achei ele estranho, ele acordou, eu: "vamos prá creche" ele falou "eи não quero ir prá creche, mamãe" ele vai fazer dois anos. Falei "você não quer?", ele falou, "não, deita vovó, deita e dorme". Ai ele deitou dormiu até nove e meia, eи tive o luxo de falar, então tudo bem você pode ficar com a sua avó. É um luxo...

A creche não tem a função específica de atender crianças doentes, mas coriza não é doença, considerando criança e creche. 
A falta de continuidade da proposta educativa da creche no ensino fundamental é um questionamento importante que remete a uma visão mais politizada da educação:

E eu questiono uma coisa: a gente se esforça para transformar este indivíduo crítico, autônomo, independente na creche, até os 6 anos de idade. E a partir daî? As nossas crianças não têm lugar garantido numa escola que dê uma continuidade naquela filosofia de ensino. O nosso G6 talvez consiga uma vaga na aplicação. Uns 2 ou 3 que uma mãe consegue pagar uma escola particular, e os outros?

Qual a sustentação para a idéia que o sistema de ensino privado está apto a essa continuidade da proposta educativa da creche?

Duas das creches da USP enfrentam problemas relativos ao espaço físico: uma por dispor de uma área exígua e outra por falta de melhor aproveitamento da área.

A estrutura física da creche, o espaço, é muito mal planejado. Nós temos um pátio que fica entre um módulo e outro, coberto, só que ao mesmo tempo ele é super aberto, é alto e é um lugar muito frio. Nesse inverno nós estamos sofrendo muito, porque, numa chuva, ele molha, no frio é um frio horrivel. No verão é excelente, lógico. Mas no inverno e na época de chuva que virá em setembro, a gente vai sofrer muito porque fica confinado.

Diante do problema de espaço físico, as educadoras questionam se conseguem garantir a proposta preconizada pela Divisão de Creches, de promover o bem-estar da criança.

E a própria filosofia do Coseas, da Divisão de Creches, que é "tudo é centrado no bem-estar da criança", por mais que a gente vire mágico, fica dificil.

Apesar dessa realidade contraditória, conseguir ter o filho na creche da USP é um privilégio, pois há certeza quanto à boa qualidade de seu atendimento. Além disso, é um privilégio pois a demanda é reprimida, o acesso não está disponível sequer para toda a comunidade universitária.

Todo mundo sabe que a creche [da USP] é uma coisa boa e a gente tem um privilégio muito grande de trabalhar lá e poder levar o filho da gente para lá, e eu queria muito poder dividir isso com cada pessoa que tem vontade de levar o filho e não consegue.

A qualidade desse serviço fica ainda mais em destaque quando se pensa na realidade mais ampla, fora do âmbito da universidade e se constata 
que não só a quantidade, mas também a qualidade da educação infantil deixa muito a desejar, está muito distante do ideal.

Numa creche do estado, pessoas que não têm qualificação para cuidar de crianças, porque o salário é baixo, está fora todo esse pensar na criança.

Dá vontade chorar, de sentir que a gente está tão distante desse ideal. A gente já sabia disso, mas, quando a gente ouve, a gente reflete mais sobre a questão: quanto a gente está distante dessa realidade que a gente está almejando.

Tem mães que precisam trabalhar e não têm onde deixar a criança. As estatísticas que falam, na verdade a gente não sabe porque no meu bairro foi uma loucura prá mãe que precisa de escola de primeira série, não tinha. E está lá as estatísticas que é 99,9\% que se tem a rede escolar, que é o básico que fala. Eé uma mentira porque não tem.

Quando o discurso das educadoras se encaminha no sentido de discutir as relações com a família, também emergem questões que se inserem no âmbito das controvérsias, e que transcendem a possibilidade resolutiva da educadora.

Essa questão da sexualidade, por exemplo, a gente vê com mais freqüência na família que a casa é menor, o pai dorme no quarto com os filhos, dá prá perceber bem, quando eles começam com as brincadeiras, e é uma questão que deixa a gente bastante de cabelo em pé. A gente vê quando é da família e quando é a televisão, porque eles trazem muita coisa da novela, o nome dos personagens, as ações. E o nosso papel: onde a gente para e entra a família? É bastante complexo.

E o ambiente sofre as influências que têm em casa que, na verdade, não estão sob nosso alcance, nem de intervir, nem de julgar, mas de facilitar para a criança sentir-se bem nesse ambiente, mesmo não sendo sempre tão positivo, às vezes traz conflitos, a gente tenta ajudar, nos momentos de fantasia, que ela se coloca.

Qual é o limite de ação das educadoras? Elas entendem como difícil definir a amplitude do trabalho, pois se deparam com comportamentos das crianças com os quais têm que lidar e cujas causas estão na realidade social e cultural das famílias, sobre as quais não podem intervir. No entanto, sentem-se compelidas a interferir nestas conseqüências de tal realidade, por entenderem que isso é deletério à criança. Transparece, também, a visão de que a educação poderia dar conta de resolver todos os problemas ou, melhor dizendo, tudo o que interpretam como problema. 


\section{- O TRABALHO NA CRECHE •}

A análise do tema $\mathbf{O}$ trabalho na creche deu origem aos seguintes subtemas: a coordenadora/educadora e o trabalho, a organização do trabalho e a formação para o trabalho na creche.

\section{PARA AS COORDENADORAS}

\section{- As coordenadoras e o trabalho}

\section{Caracterização das coordenadoras}

Foram entrevistadas sete coordenadoras, cujas idades variavam entre 29 e 56 anos, sendo a média 41 e a mediana 40 anos. Três delas tinham formação em psicologia, duas em pedagogia, uma em enfermagem e apenas uma ainda não havia completado sua formação no $3^{\circ}$ Grau, tendo feito magistério.

O tempo de trabalho na creche variou de 4 a 19 anos e o tempo de atuação em educação infantil de 4 a 24 anos. Apenas uma delas não teve experiência anterior com educação infantil. As demais tiveram experiências em outras creches ou "escolinhas" (3), escolas (2), escolas para crianças com necessidades especiais (2), Febem (1). Todas as coordenadoras referem que trabalhar com educação infantil atualmente é uma opção, sendo que uma delas voltou-se para essa área inicialmente devido à possibilidade de trabalho em horário mais compatível para a organização familiar e outra fez essa escolha porque acatou a sugestão de sua mãe.

Cinco coordenadoras já tiveram filhos freqüentando as creches da USP e duas não têm filhos. Apenas uma referiu ser chefe de família.

Quanto à participação em grupos/associações, três não participam de qualquer das modalidades questionadas (igreja, bairro, trabalho, escola), três referiram participar em grupos relacionados a trabalho, duas delas também a grupos relacionados à escola e uma à igreja. Em relação a atividades nas horas de folga, todas apontaram leitura e cinema, 6 responderam também tv/vídeo, duas esportes e duas teatro. Os tipos de leitura foram assinalados como a seguir: diariamente - jornais (6), livros (7); esporadicamente - jornal (1), revistas ("veja", "isto é", "época") (6), outras revistas e gibis (5). 


\section{O impacto do trabalho sobre as coordenadoras}

Em relação ao impacto do trabalho na educação infantil sobre a equipe, as coordenadoras declaram sentir satisfação com seu trabalho, ao mesmo tempo em que identificam elementos que pensam gerar insatisfação para as educadoras. Dentre os aspectos do trabalho que lhes são gratificantes, destacam a satisfação em acompanhar o desenvolvimento das crianças.

Realmente, é o que eu gosto mesmo de fazer. Eu fiz pedagogia e fiz certo. Em termos profissionais, eu estou resolvida porque foi mesmo o que eu queria.

Trabalho há 15 anos só com essa faixa etária. Acho uma delícia. É a base para tudo. Aprende a falar e é gostoso ouvir as primeiras palavras, a ampliação do repertório. É engraçado, ao mesmo tempo, é legal.

Outro aspecto que dá significado ao trabalho é a possibilidade de contribuir com o seu conhecimento para promover uma melhor atenção às crianças na creche pelas educadoras e também compreender e lidar melhor com as famílias.

Na verdade, eu tenho algo importante a oferecer. Meu trabalho hoje em dia não é direto com crianças. Eu tenho muito atendimento com famílias, que é uma parte que eu gosto muito porque eu fiz formação psicanalítica. Eu consigo entender muito da dinâmica da família e como ela reflete para a criança e a criança traz isso aqui para dentro. E, no trabalho de formação com os educadores, que também é algo que me interesso muito porque eu entendo muito de desenvolvimento da criança, eu tenho como tentar favorecer o desenvolvimento dessas crianças, através dos adultos que têm contato direto.

Essa satisfação se confirma pelas respostas à questão sobre as expectativas em relação ao trabalho: todas afirmam que não pretendem mudar a área de atuação, apenas aprimorar-se. Em duas respostas, apareceu uma queixa sobre o salário.

Em toda a análise, evidencia-se que o trabalho da coordenação é fundamental para o processo de organização, a flexibilidade das condutas, a formação continuada, segundo uma concepção bastante ampliada da usual.

O meu trabalho como diretora é perceber que, por exemplo, a questão da alimentação não se restringe só à situação da criança. [Precisa] pensar num contexto maior: o que é a alimentação, como a gente se relaciona com isso, que alimentação tem na minha casa, que alimentação eu dou para as crianças na creche, se eu estou com fome na hora de comer ou não. $O$ nosso trabalho, enquanto coordenação, é trazer à consciência as dificuldade que 
estão presentes na relação [do educador com o trabalho]. À medida que a coordenação consegue trabalhar com clareza com isso, em relação aos educadores, isso vai se tornando mais apropriado. O cuidado não termina na criança, eu tenho que cuidar também da relação dos adultos e das crianças, das nossas relações enquanto cuidadores e educadores.

\section{Percepções sobre o impacto do trabalho sobre as educadoras}

As coordenadoras entendem que, para as educadoras, o trabalho com a criança pequena causa um grande desgaste físico, pois há uma constante requisição desta para manter a segurança da criança, realizar sua higiene, darIhe aconchego. Essa demanda de atenção constante e a preocupação com o bem-estar da criança também provocam desgaste emocional.

É difícil, é um desgaste, físico e emocional, muito grande. Como a criança [pequena] não fala, você tem que entender, interpretar; é o modelo, é o falante, é o andante. Você é o modelo o tempo inteiro, você se dá o tempo inteiro. Senta, levanta, troca fralda, dá banho e aí ele chora, aquele dia ele está doente e precisa de um cuidado especial, mas você tem o restante do grupo.

Um aspecto do trabalho com as crianças menores que as coordenadoras identificam como frustrante para as educadoras é a ausência de produto visível, mensurável. A criança pequena não tem uma produção que represente a influência da educadora, tal como a confecção de trabalhos manuais, ou que demonstre um aprendizado proporcionado por ela, mediante $o$ desenvolvimento da leitura, da escrita ou da matemática. Isso pode lhes causar angústia, particularmente quando comparam os resultados e aquisições das suas crianças com as maiores.

$O$ trabalho com a criança de 0 a 3 anos na creche é um desafio, porque as pessoas querem produto, mas de 0 a 3 anos não tem esse produto palpável. Quando você passa no corredor da creche e vê a exposição do Matisse, do Amílcar de Castro, realizada pelas crianças maiores, dá uma coisa, se isso não está bem resolvido.

A presença do adulto não está na produção [da criança pequena, tal como] numa criança que entrou na escola sem ler e sai no final do ano lendo. É difícil para as educadoras encontrarem no ato da criança algo que mostre a presença delas, que marque onde elas fizeram a diferença para a criança.

Essa perspectiva da falta de produto pedagógico sugere que a medida para avaliar o trabalho é aquela importada do ensino fundamental tradicional, centrada no ensino de competências para a realização de tarefas acadêmicas. Sugere, ainda, que não se construiu um rol de resultados específicos 
esperados para a educação infantil. Assim, embora a equipe da creche realize uma série de cuidados efetivos para o bem-estar das crianças, que promovem seu desenvolvimento e aprendizagem, a ausência de um quadro conceitual que ampare e sustente esse cuidado não permite que ele seja visto, sistematizado, avaliado e computado como produto de um trabalho profissional.

Alguns exemplos de produtos relativos ao trabalho com crianças pequenas que podem ser avaliados são: em que medida a criança está livre de infecções, dormindo, alimentando-se e/ou mantendo rotinas estáveis; o quanto ela brinca, explora, pergunta, busca ajuda quando precisa, demonstrando confiança em si e nos educadores; o quanto os adultos estão realizando cuidados de modo sistematizado; quanto a família está tranqüila e informada a respeito da vida da criança na creche.

Entretanto, é correto afirmar que, no percurso da instituição creche, muitos desses aspectos nunca foram sistematizados. Exemplificando, a proposta higienista deveria visar, minimamente, o produto "o quanto a criança está livre de infecções", mas, conforme Demo (1995) e Machado (1991), o que se observa é um grande paradoxo: programas que escolhem ou priorizam os aspectos de cuidado e, contudo, apresentam resultados alarmantes em relação ao cuidado infantil, os quais resultam, em geral, em epidemias crônicas. Os autores citam como problemas: equipamentos sujos, crianças confinadas, tanques de areia vazios e/ou maltratados, iluminação e acústica inadequadas, higiene pessoal dos adultos e crianças pouco cuidadas, maus odores acentuados, falta de material de limpeza e conservação.

Assim, embora as creches universitárias apresentem resultados bastante satisfatórios, no que diz respeito aos cuidados citados, esses resultados não são reconhecidos pelo grupo de educadoras como frutos de sua função profissional.

Os relatos permitem notar, também, que a maternagem não é vista como um cuidado profissional. Contrariamente a essa visão, Robertson e Robertson (1973) mencionam algumas funções tidas como maternas, mas que precisam ser realizadas por outras pessoas e profissionais quando uma criança está sob seus cuidados: interpretar o ambiente para a criança, oferecendo brincadeira, conforto e apoio adequados e compartilhando seus prazeres e 
ansiedades de maneira empática; manter o ambiente o mais seguro possível para a criança, ajudando-a a lidar progressivamente com as dificuldades e frustrações à medida que se desenvolve. Cada uma dessas ações encontra-se também descrita, juntamente com várias outras, relacionadas à saúde, higiene e alimentação, no Referencial Curricular Nacional para a Educação Infantil (Ministério, 1998), como ações de cuidado a serem realizadas pelo educador junto à criança.

Além de o produto pedagógico ser oculto/invisível, o trabalho das educadoras com as crianças pequenas se confunde com o cuidado familiar, sendo difícil separar a intervenção profissional daquela realizada no ambiente doméstico. Algumas reações de pessoas leigas demonstram como o cuidado da criança é desvalorizado socialmente. Assim, é freqüente as educadoras ouvirem comentários de estranhamento em relação ao trabalho que realizam, pois, segundo o senso comum, não seria necessária formação acadêmica ou sistematizada, uma vez que as crianças pequenas não recebem aulas.

Socialmente, [as educadoras] são discriminadas. Um vizinho perguntou: Onde você trabalha? A educadora falou, com orgulho "na creche da USP, no berçário". E ele "O que? Você estudou para limpar bunda de criança?" Dá uma mexida na hora de falar que é educadora do berçário. Um outro fala: "Mas como? Você dá aula no berçário? E quem limpa a bunda dela? Quem é sua auxiliar?" A criança não é entendida integralmente, nem socialmente, nem pelas instituições que formam.

Difícil lidar com o cuidado de uma criança, especialmente até 3, 4 anos, sem se misturar com a família, com o que é cuidar da criança, acompanhar a criança aprendendo a andar, falar, comer, deixar de fazer xixi e cocô na fralda.

Esses relatos permitiram a identificação de algumas representações:

- Cuidado como atividade que não demanda uma base de conhecimento, ao contrário da educação.

- Cuidado infantil como pertencente ao âmbito da família.

Em relação ao primeiro ponto, presume-se que essa visão decorra de que o cuidado com o corpo da criança implica um trabalho manual, o que vem sendo realizado em toda história da humanidade como atividade simplesmente prática, segundo bases empíricas, tendo, portanto, menor valor social. A respeito do descrédito do trabalho manual, Freyre (1978) resgata fatos que podem ter originado tal representação em nosso meio: 
"A relação de desamor do português (ainda em Portugal e principalmente no Brasil) pela terra, pela lavoura e pelo trabalho agrícola (tal como esse trabalho tem sido estimado nos outros países) (...) parece-nos evidente (...) devido ao pequeno número de colonos portugueses dispostos, no Brasil, aos ofícios manuais (...) esses ofícios e serviços passaram a ser desempenhados e prestados por escravos resultando (...) o desdouro do trabalho manual, particularmente do campo (...)".

Quando se diz que não é necessário curso superior para fazer higiene, trocar fraldas, dar banho na criança, isso pode ser válido para o ambiente doméstico, mas não o é para o espaço coletivo (Rosemberg, 2001). No espaço coletivo, a simples higiene tem que ser feita com competência, pois, do contrário, torna-se um risco à saúde das crianças e dos trabalhadores. Essa competência implica em compreender processos de contaminação pessoal e ambiental até que, em cada um desses momentos, o desenvolvimento da criança também está sendo influenciado, seja na formação de sua identidade, seja na incorporação de valores relativos ao cuidado com o corpo, por exemplo.

Quanto ao segundo ponto, a idéia de que a educadora confunde-se com a família quando cuida da criança decorre de que o cuidado infantil é tido como função materna. Badinter (1985) revela que a sociedade moderna ocidental atribui à mulher a principal responsabilidade pela sobrevivência, saúde e educação do filho. Postula que ela foi dotada pela natureza de condições ideais para o cuidado infantil. Tanto que, historicamente, o atendimento das crianças em creches tem sido feito por leigos, predominantemente, em geral com precária instrução formal. Assim, não é de estranhar que as pessoas esperem que essas atividades sejam executadas por uma auxiliar (basta ser mulher) e que apenas as funções mais nobres, as educativas, sejam da professora.

As coordenadoras percebem que essas representações correntes em nosso meio causam um impacto negativo sobre as educadoras, que sentem seu trabalho menosprezado.

Aparece aí também uma concepção simplista sobre educação como "dar aula" e, portanto, torna-se incompreensível, para os leigos, a função de uma professora no berçário. Conforme pode ser percebido nos depoimentos, tais concepções simplistas, tanto para o cuidado quanto para a educação, embora sejam do senso comum, também estão presentes nos membros da equipe. As 
educadoras ingressam na creche com essa visão e o processo de mudança é lento e gradual.

A gente já avançou bastante, mas eu vejo isso ainda como um nó que não conseguimos desatar inteiro. Antigamente, era bem dividido, a área do saber e a do cuidado da criança. Tanto que era mais valorizado o educador do módulo 3. As pessoas achavam que quem ia para o módulo 3 estava recebendo uma promoção, porque lá você ensinava a ler, lá você ensinava a escrever. A [atividade] da salinha ["sala de aula"] é uma coisa super valorizada e a outra parte não tem um empenho tão grande como tem na parte de sala. Isso foi se modificando, mas ainda às vezes a gente tem que estimular um pouco, isso faz parte da avaliação delas. Eu não vejo que elas não entendam isso, mas acho que tem essa visão de professor, que só é bacana o que ele faz em sala, quando a criança aprendeu a ler, a escrever, quando ela sabe sobre Picasso, Michelângelo.

Para que essas concepções sejam superadas e as ações de cuidado e de educação sejam integradas, a formação permanente em serviço torna-se fundamental, considerando que a formação acadêmica dos professores não os capacita para atuar na educação infantil.

\section{- A organização do trabalho}

Um dos aspectos enfatizados relacionou-se à organização do trabalho, mediante o planejamento das atividades que são realizadas com as crianças. Há um investimento para que o trabalho na creche não seja improvisado, o que mostra uma concepção de trabalho com criança radicalmente diferente da do senso comum, na qual o trabalho com a criança é intuitivo, não necessitando, inclusive de preparo profissional.

Por outro lado, foi destacada também a necessidade de flexibilidade no trabalho com a criança, devido à dinamicidade e imprevisibilidade das situações.

\section{O planejamento e a avaliação das atividades}

Antes de a criança começar a freqüentar o serviço, inicia-se um processo de planejamento para sua recepção, visando que sua adaptação seja bem sucedida. Esse processo inicia-se com uma coleta de dados sobre a criança e a família, que são discutidos pela equipe, a fim de personalizar o atendimento. Além disso, define-se qual educadora será referência para a criança, ou seja, a 
pessoa mais diretamente envolvida com sua adaptação.

Nos bastidores, após cada entrevista, a cada exame médico, a gente preenche uma ficha e tem reuniões com a psicóloga e comigo, para estar discutindo sobre cada criança. A gente procura organizar a rotina naquele dia, a referência, para receber aquela família.

As propostas de trabalho são planejadas e avaliadas regularmente, incluindo tanto as propostas coletivas, tais como os projetos pedagógicos, bem como as atividades realizadas para atender particularidades, durante 0 processo de adaptação ou após esse período. Com isso, é possível identificar as ações que trazem resultados positivos e reforçá-las, além de questões que precisam ser modificadas.

E isso a gente está sempre revendo nesses encontros. Por isso é importante essa parada mensal, é o momento que você para, que você recicla a memória. Isso não deu certo, vamos retomar. Como é que a gente faz. Fala de cada criança.

Entretanto, especialmente para as crianças menores de 3 anos, 0 planejamento de atividades demanda criação e construção, devido à carência de propostas. Segundo Bondioli e Mantovani (1998), faltam "pontos de referência suficientes para constituir as bases de uma pedagogia das crianças muito pequenas", bem como há "ausência de critérios precisos sobre os quais fundamentar a profissionalidade dos educadores". Ainda como hipótese para essa ausência de propostas, podemos considerar que, nessa faixa etária, há um forte componente de cuidado, que ainda não está sendo explorado conceitualmente.

O Referencial preconiza que o ponto de partida para a proposição de atividades deva ser a própria criança. Para isso, é necessário proceder à observação e à análise de seu comportamento em cada atividade, o que é referido como uma tarefa nada fácil.

É muito diferente fazer um projeto, um planejamento para as crianças pequenas. Uma educadora, que está no terceiro ano de Pedagogia, falava "Eu fico meio assustada, aprender o movimento das crianças e a partir desses movimentos, re-planejar sua atividade novamente". Ela planejou uma atividade interessante para as crianças andarem na creche, brincando de carrinho puxando com o cordão. Aí, foi analisando para ver quais eram as dicas que as crianças davam, "quando a gente for brincar de carrinho a gente tem que brincar só de carrinho e não ficar andando para ir na sala da fantasia. E eu percebi que o tamanho do cordão era muito grande para as crianças daquele tamanho, tinha que ser menor". São coisas aparentemente 
pequenas, mas que se a gente aprender a olhar, vai ver quanto o planejamento vai ficando rico.

Esse movimento de rever e reciclar a própria prática resulta em maior satisfação profissional, pois se torna possível perceber que o atendimento à criança melhora e o trabalho do educador também.

Hoje, é super legal, ter o espaço previamente organizado, está ali a todo o momento, quando a gente para, para pensar na atividade do pequeno grupo, eu tenho aquele material ali e eu posso propor uma outra coisa e as crianças podem percorrer aquele espaço. E não fica centrado no adulto.

Para a coordenadora, é o caráter de trabalho planejado que diferencia o cuidado na creche do cuidado que é oferecido à criança em casa. Isto porque o cuidado profissional se constrói sobre bases diferentes das maternas. Por exemplo, a identificação das necessidades da criança e a maneira de atendêlas, bem como o efeito que cada ação tem sobre o desenvolvimento infantil são avaliados sistematicamente. Ao mesmo tempo, lembra que há um aspecto que precisa ser semelhante: o afeto, pois é uma condição necessária para obter resultado no trabalho com as crianças.

O que diferencia o trabalho do educador de berçário da função materna é exatamente esse trabalho de formação, essa competência. Quando a criança não quer comer, a mãe fica desesperada, porque o importante para mãe é que a criança se alimente. O educador tem que ter outra visão: o que está acontecendo que a criança não está conseguindo comer? Às vezes é naquele dia, é aquela refeição, porque tomou lanche demais, aí eu vou oferecer mais tarde. Às vezes porque está confusa, é uma criança que acabou de entrar na creche, e é muito barulho; Às vezes eu tenho que dar essa refeição num outro espaço; é uma criança que tem um hábito diferente. Por que o furo da mamadeira tem que ser pequenininho, tem que gotejar? Porque ele tem que fazer um certo movimento de lingua, de bochecha, fortalecer a musculatura. Enfim, toda a coisa técnica mas sem perder o afetivo, sem ser frio naquela situação. A gente tem que ter essa coisa do afeto, assim como em casa, quem cuida, seja a mãe ou o pai. É fundamental esse vínculo afetivo senão você não consegue absolutamente nada com as crianças, mas ter um olhar mais técnico, sem dúvida.

Ao falar da competência necessária para o cuidado, as educadoras a relacionam ao trabalho de formação, reiterando a concepção de um trabalho profissional e não um simples "fazer como se faz em casa".

A forma como foi apresentada a necessidade do estabelecimento de uma relação afetiva entre 0 adulto e a criança sugere uma visão de senso comum, uma representação do bom cuidador como aquele capaz de oferecer 
amor e carinho. Se nem mesmo para a mãe ou para o pai pode-se prescrever que amem seus filhos, então, como fazê-lo para os educadores? A questão da afetividade também demanda um olhar técnico-científico, um embasamento teórico que permita selecionar e implementar ações eficazes para 0 atendimento às necessidades emocionais da criança.

\section{A flexibilidade no atendimento da criança}

A organização do trabalho, que se expressa no uso do espaço físico, nas rotinas, nas propostas de atividades, nas formas estabelecidas de responder às situações na creche, não deve significar que o trabalho na creche seja estruturado de maneira rígida. Ao invés de arbitrárias, as regras precisam ser passíveis de mudança. É possível perceber que as mudanças têm como perspectiva a melhoria da qualidade do atendimento oferecido, tornando-o mais adequado às necessidades das crianças e de suas famílias e aos objetivos da instituição.

Nós temos que pensar bastante. Quando a gente organiza uma rotina aqui na creche, não pode levar em consideração só os aspectos da organização do trabalho: "agora é hora da atividade, agora é hora da refeição e agora é hora de dormir". Principalmente quando se trabalha com criança muito pequena, tem que ter uma rotina, é importante, sua organização, mas ela tem que ser bastante flexivel no sentido de atender as particularidades e individualidades, respeitar um pouco o ritmo das crianças e das famílias também.

Para que o trabalho seja flexível e, ao mesmo tempo, organizado, há um processo constante de reflexão sobre o que é feito e sobre as respostas e demandas das crianças. Essa reflexão pode levar a uma revisão das propostas estabelecidas e formulação de novas propostas, mais apropriadas:

Na hora, nós conversamos que seria impossivel [mudar a rotina de repouso]. Depois analisamos e achamos que nós temos que pensar realmente no problema. Eu falei: nós vamos mudar essa situação. Foi uma coisa emergente, então conversamos: vamos mudar essa situação, quem não quiser não vai dormir e vão ficar com uma educadora. Você fica muito naquela do não, isso eu não vou mudar porque a norma é assim. Tem que pensar realmente na criança, então nós vamos mudar essas coisas por conta dessa criança, e assim, os outros que não quiserem dormir também não vão.

Antes de a gente pensar essa coisa era totalmente diferente: hoje vai ter atividade de movimento, e só tinha uma opção. Está errado, é um pensamento para uma criança maior. 
As características de trabalho organizado com condutas flexíveis conferem à creche uma condição de serviço de boa qualidade. Mas, para que se concretize dessa forma, cada um precisa assumir o compromisso e a responsabilidade de buscar o melhor.

Tem que ter uma relação de confiança com toda essa equipe, construída, com cada um. É muito complicado se você tem um educador que você não confia, um funcionário da limpeza que se irrita. Não dá prá gente se sentir ameaçado em canto nenhum. Eu tenho que responder e saber por quem eu estou respondendo. $O$ sentimento de equipe é muito importante. Tem uma responsabilidade que o tempo inteiro é partilhada com toda a equipe, que todos precisam estar percebendo todos os furos, todos os perigos, onde a gente está falhando e saber dizer isso. A gente aprendeu a fazer isso bem; a gente tem uma equipe que funciona de uma forma solidária, coerente, participativa, que a gente criou naqueles círculos, naqueles trabalhos mais partilhados, nos quais as pessoas se sentem de fato implicadas e responsáveis pelo trabalho que elas estão fazendo, não é assim "se der errado a diretora vai se ferrar". É um desafio, construir de um bom jeito prá gente poder chegar prá um pai com toda conviç̧ão e dizer "seu filho vai ficar bem aqui, pode confiar na nossa equipe".

Há alguns limites à flexibilidade: novas propostas de atendimento muitas vezes são de difícil realização em função das possibilidades concretas do serviço, que são os recursos humanos e materiais.

Em relação aos recursos humanos, por exemplo, a equipe sabe da importância de que haja uma pessoa na creche que constitua referência para a criança, para promover sua adaptação, isto é, alguém que estará junto a ela a maior parte do tempo possível durante esse processo. Mas isso esbarrava no seguinte problema: $O$ que fazer na ausência da educadora de referência? Resolveu-se, então, atuar com duas educadoras para cada criança, fazendo o papel de referência.

As pessoas adoecem, saem de licença médica, não vêm. Então, atualmente, a gente trabalha com uma dupla de referência, exatamente para dar um pouco mais de segurança para essa criança vir de casa.

E, finalmente, a maneira de estruturar e dividir o trabalho, mais do que organizá-lo, reflete as concepções das coordenadoras sobre ele, ajudando a reorientar as concepções das educadoras.

Não existe uma valorização maior do educador que está no pré em relação àquele que está no berçário. E existe uma intenção de circular: por exemplo, não existe ele começou no berçário, mas já está no pré, como se já estivesse mais capacitado. É uma idéia que a gente vem trabalhando: educadores que tem um ótimo trabalho e saem (do pré) e vão para o berçário porque eles vão contribuir e já estão mais capacitados a mostrar 
o trabalho para educadores novos. Entre nós isso é muito valorizado. À medida que a coordenação tem isso claro e consegue trabalhar com clareza com isso, em relação aos educadores, isso vai se tornando mais apropriado. Eu não diria completamente claro prá todos. Até porque existe uma rotatividade de educadores e quando chega um educador novo, muitas vezes, ele chega com esses conceitos que são presentes no nosso ambiente social.

\section{- A formação para o trabalho na creche}

Conforme comentado anteriormente, a formação em serviço é a principal estratégia para a construção da proposta de trabalho junto à criança e, ao mesmo tempo, o grande desafio da coordenação.

$\mathrm{Na}$ universidade, o trabalho de formação é orientado pelas equipes de coordenação das creches e da Divisão de Creches da Coseas, mediante a organização de reuniões, grupos de estudo, encontros de creches, e participação dos trabalhadores em eventos técnico-científicos, periodicamente.

Entretanto, mediar essa formação no dia a dia não é uma tarefa fácil para as coordenadoras, porque elas também estão construindo esse conhecimento, não foram preparadas durante sua formação acadêmica. Assim, percebem que seus conhecimentos ainda não respondem a todas as demandas da prática. Acresce-se a esse fato a escassez de investigações e referências bibliográficas que auxiliem a compreensão e o debate do tema. $\mathrm{A}$ esse respeito, o Referencial foi apontado como uma fonte bibliográfica importante.

A gente tem estudado nas reuniões sobre o trabalho com crianças pequenas, buscando adequar, mas é difícil encontrar material escrito. É mais a experiência da gente, a gente tenta teorizar, discutir; tem poucas, pouquíssimas produções para essa faixa etária.

Eu tinha uma dúvida que era a seguinte: porque eu vou falar em trabalho pedagógico com crianças bem pequenas? Sendo que o mais importante é a relação do educador com essas crianças, como ele olha, como ele fala, como ele canta, como ele leva para passear na creche. Mas depois que saiu os referenciais e que tem algumas coisas que deu para estar fundamentando melhor, agora a gente já tem um trabalho mais sistematizado, nessa questão do pedagógico, mesmo com as crianças pequenas. A gente foi aprendendo coisas interessantes, contemplar garatuja, os rabiscos das crianças. Elas acham estranho, mas estão aprendendo. Porque se você começa também a entender a arte contemporânea e você entra num espaço que tem uma Mônica, cujas obras 
eu conheci, que são garatujas. E tem fina, forte, e eu fui aprendendo que as linhas têm vida e foi bárbaro porque foi desbravando.

Apesar dessas dificuldades, as equipes de coordenação assumem o compromisso e investem no trabalho de formação que tem se concretizado como um recurso também para valorizar o cuidado. Isto se evidencia, por exemplo, nas falas sobre as reflexões que vêm sendo realizadas acerca do trabalho no berçário, configurando o caráter educativo que o cuidado pode assumir, segundo a forma como ela seja proposto e realizado.

Teve um ano em que a gente investiu muito na idéia de repensar o que éo berçário, a importância do berçário, a importância do cuidar, tão educativo quanto um trabalho, um projeto.

A pedagoga, a equipe e a psicóloga, também, fizeram um trabalho nesse sentido, nas reuniões de formação: cuidar e educar são duas coisas que caminham junto. A gente não tem que planejar só as atividades pedagógicas; a gente tem que pensar, planejar, também a hora do sono, a hora da comida, essas coisas dos cuidados.

Os relatos permitiram identificar algumas premissas metodológicas do processo de formação conduzido pelas coordenadoras, tais como a sistematização e continuidade das atividades, bem como o investimento em estratégias pedagógicas participativas e reflexivas. A respeito da formação permanente em serviço realizada na creche, Cipollone (1998) afirma:

"A atualização como ação de construção do profissionalismo permite a passagem de trabalho espontâneo a trabalho "controlado" cientificamente, que se determina transformando o evento educacional em evento pedagógico".

No que diz respeito à sistematização e continuidade desse processo, o planejamento do trabalho prevê uma programação de reuniões periódicas entre as educadoras dos mesmos grupos de crianças, e destas com as coordenadoras.

Ao longo de um tempo, nessa discussão, elas vão percebendo isso e tentando entender: o que eu estou fazendo agora, estou cuidando, estou educando? Que trabalho é esse com a criança tão pequena? Esse é um trabalho que eu estou fazendo a todo o momento com as educadoras.

Um aspecto enfatizado pelas coordenadoras foi a opção em promover reflexões sobre a prática com vistas a fundamentar o trabalho à luz do conhecimento científico.

A valorização das ações de cuidado se dá à medida que estas são 
investidas de um caráter educativo. Dentre os exemplos citados, destacam-se os referentes à alimentação, em que o cuidado embasado em conhecimentos técnicos passa a constituir uma atividade educativa aos olhos da equipe.
Hoje, é interessante ver o trabalho com a criança de 0 a 3 anos, é prazeroso, é gostoso. E a criança que não comeu, por que? Valorizar isso como um trabalho educacional mesmo. Tem todo um trabalho e é bonito ver essa aprendizagem, mas é em serviço.

Um aspecto importante ressaltado quanto ao trabalho de formação foi que este não se restringe a algo superficial, à busca de mudança de comportamento. Antes disso, busca uma intervenção mais aprofundada, pois tem como horizonte modificar atitudes e práticas. Para tanto, as coordenadoras valem-se de estratégias participativas para promover a reflexão, buscando integrar conhecimentos, sentimentos e ações.

A gente tem trabalhado sistematicamente, ao longo de vários anos, com essa idéia: o que é o trabalho educativo com o bebê? Com as crianças maiores? Mostrando, revelando e conseguindo traduzir esses conceitos e essas idéias que são educativas. Esse é o nosso desafio. Eu percebo que, à medida que isso é compreendido, é cada vez mais valorizado, é cada vez mais apropriado enquanto trabalho que eu posso me orgulhar, pelos educadores da creche, que ele vinha com uma certa vergonha de "limpar bunda de nenê".

Foi destacada a importância do diálogo e da necessidade de explorar, junto com as educadoras, as situações vividas no trabalho, buscando a compreensão mais aprofundada.

Nas nossas reuniões, uma metodologia que eu estou usando atualmente, é
criar polêmicas. A partir da polêmica, o grupo vai pensar. Tento ver o que
os educadores estão pensando, o que está por de trás, porque muitas coisas
podem aparecer não da teoria, mas da vivência delas. E aí, partindo de
seus conhecimentos prévios, vou relacionando a teoria e a prática aqui do
dia a dia.

Durante as entrevistas, não foram explicitados marcos teóricos que fundamentam essas formas de atuar no processo educativo permanente da equipe. As idéias apresentadas na primeira fala aproximam-se da pedagogia da problematização, que pressupõe o contato com a realidade e valoriza as experiências prévias das pessoas envolvidas, buscando nexos entre os conhecimentos já assimilados sobre $\mathrm{o}$ assunto e as experiências pessoais vividas (Freire, 1981). A grande força dessa abordagem é que possibilita 0 
avanço qualitativo no processo de formação de profissional construtivo e criativo.

Pascal, Bertram (1994) discutem a educação infantil e a formação de professores em países da Europa, considerando a "clara evidência de que a qualidade do professor é um determinante central na qualidade e eficiência dos programas de educação infantil". Apontam como uma tendência a adequação do currículo e da metodologia de ensino ao desenvolvimento infantil, o que implica o "afastamento de modelos formais de instrução, em favor de métodos mais experimentais, ativos, centrados na criança, além do afrouxamento da determinação central de conteúdos curriculares", bem como à "elevação do nível e à expansão das oportunidades de formação profissional de professores pré-escolares".

No processo de formação, além dos aspectos cognitivos, precisam ser trabalhados os aspectos da afetividade, dos sentimentos vividos pelas educadoras nas relações de trabalho:

No dia-a-dia, a gente vai conseguindo identificar e discutir [sobre as expectativas das educadoras em relação à família], na hora em que se dão os confrontos entre educador e família. A gente vai tentando conversar e explicitar o que está por trás do discurso, as contradições, na maneira como [a educadora] fala da família, quando aparece um certo tom, na hora de tratar de uma questão sobre a criança. Não é fácil, não é fácil. Principalmente numa instituição que se toma como excelente, é muito difícil as pessoas verem onde estão "os buracos" e admitirem sem pensar nisso como uma crítica, um julgamento do que elas estão dizendo. A gente vai tentando mostrar essa contradição, para que as pessoas se dêem conta disso e tentem trabalhar de uma maneira diferente.

Nesse trecho, aparece como grande desafio do trabalho de formação explicitar e lidar com questões que, muitas vezes, ficam escondidas. Mas se justifica porque as emoções interferem no cuidado que é prestado à criança $e$ só o reconhecimento e o manejo das emoções envolvidas nas situações do dia-a-dia pode tornar completo o processo, pois a própria aprendizagem é mediada pela afetividade. Ao abordarem o preparo dos educadores para atuar junto às crianças pequenas, Bondioli e Mantovani (1998) destacam que, diante de situações que envolvem também o plano emotivo, é necessário atualização contínua e supervisão. A coordenadora aponta esta como a parte mais delicada do trabalho de formação, mais difícil de trabalhar do que 0 
conhecimento técnico, pois pode desencadear resistências e barreiras à comunicação quando mal interpretada.

O fato de uma pessoa saber coisas, ter conhecimentos, não faz com que ela tenha um bom cuidado e uma boa relação com a criança, porque está incluído, em qualquer relação, ciúme, inveja, posse, dificuldades, angústias, conflitos. As pessoas tendem a entender perguntas sobre esses sentimentos como: isso está errado, você não pode sentir. Acho que essa é a maior dificuldade no contato com o educador: poder falar coisas e perguntar coisas que signifiquem para pessoa "eи quero te ouvir". Esses sentimentos não precisam estar excluídos, só precisam ser pensados e trabalhados. Conhecê-los e não transmiti-los à família, ou não transmitilos na relação com a criança, é muito mais árduo e difícil.

Um exemplo relacionado à higiene mostra como a coordenadora aliou reflexão de sentimentos e ações concretas para promover mudanças na relação das educadoras com atividades que são vistas como depreciativas.

Essa questão, por exemplo, do limpar a bunda do nenê ser educativa, a gente trabalhou ao longo de um período grande, junto com a questão do lixo, da reciclagem, do mau cheiro, da humilhação, da importância e do educativo que é tudo isso. Foi interessante, num determinado momento, perceber que esse trabalho social, cultural, em relação à questão do lixo, passava muito pelos mesmos sentimentos despertados com o trabalho de limpar a bunda de nenê: a questão do mau cheiro, a humilhação e o quanto não é dignificante o trabalho de fazer isso. E a gente fez um movimento na creche de todo mundo ir mexer com o lixo. Todos os segmentos da creche, de uma forma igual para todos, fizeram esse trabalho. Nesse caminho de, em algum momento, romper com algumas hierarquias e fazer coisas dentro da creche, não de uma forma exemplar, mas de uma forma compartilhada, ajudou, num determinado momento, a gente a romper essas coisas.

Verifica-se que o processo de formação nessas creches atende às condições fundamentais para a atualização permanente realizada nas creches italianas, identificadas por Cipollone (1998): a programabilidade, a continuidade, a territorialidade e o coletivo.

A programabilidade diz respeito ao planejamento da atualização segundo regras científicas implícitas para a elaboração de um projeto: o conhecimento da realidade, os objetivos e estratégias para seu alcance. Assim, um plano de atualização resulta de um "estudo sobre as necessidades formativas e características do contexto nas quais elas emergem, de uma escolha de campo e de instrumentos de intervenção que serão verificados na própria realização da atualização". 
A continuidade faz-se necessária pela característica do serviço (educacional) sendo, portanto, uma atividade que ocorre simultaneamente à realização do próprio trabalho. É prevista no planejamento segundo os tempos necessários em função dos objetivos.

A territorialidade corresponde à definição de planos de atualização para cada creche e de planos para o conjunto de creches. Na creche, encontram-se diferentes estilos de educação, partindo-se dos conhecimentos e da valorização do fazer de cada um, bem como é onde se identificam os recursos que são a matéria do trabalho cotidiano. Nos encontros de creches, comparamse diferentes percursos, colocam-se soluções positivas e erros à disposição de todos e "alcançam-se níveis de informação e de conhecimento comuns sobre questões relevantes para todo o serviço".

No caso das creches italianas, "o coletivo é uma sede técnica de trabalho com adultos em formação e, ao mesmo tempo, uma metodologia participativa". No coletivo, realiza-se um modelo pedagógico aberto, problemático, continuamente em processo, através da contribuição do conhecimento de todos os componentes.

A esse respeito, o Referencial (Ministério, 1998) afirma:

"O coletivo de profissionais da educação infantil, entendido como organismo vivo e dinâmico, é o responsável pela construção do projeto educacional e do clima institucional. A tematização da prática, o compartilhar de conhecimentos, são ações que, conduzidas com intencionalidade, formam o coletivo, criando condições para que o trabalho desenvolvido seja debatido, compreendido e assumido por todos".

A formação inclui, ainda, lidar com as dificuldades, limites e dilemas do trabalho:

Tem questões importantes, [por exemplo,] o educador ter que estar oferecendo a comida que ele tem vontade de comer e que ele não pode comer. Eu lembro bem a educadora falando "aquele pão de queijo que chega quentinho, você tem muita vontade de comer, fica babando prá comer, você tem que dizer prá criança que é muito gostoso, mas você não pode comer". Enquanto diretora, eu não tenho poder prá modificar isso, porque é uma regra institucional. A gente nunca vai conseguir que uma pessoa com fome, com vontade de alguma coisa, dê o alimento de um bom jeito para a criança.

É no trabalho conjunto, na constância das interações, na relação dialógica, que as coordenadoras vão construindo o processo de trabalho 
juntamente com as educadoras.

Eu tento descobrir com elas: olha quanto vocês estão aprendendo. Porque a criança não verbaliza, mas ela olha, ela chega perto, ela fala coisas para você de outro jeito, e a gente vai tendo sensibilidade para aprender isso.

As educadoras, às vezes, falam "nossa, eu não agüento mais dizer para fulano que não é para fazer isso, não pode". É assim mesmo, a gente fala, precisa ter paciência, que as respostas não são imediatas. Ele vai aprender que isso pode, aquilo não pode, às vezes com 5, 6, 7 anos, quando já saiu da creche. E é esse o nosso papel: repetir, repetir, repetir. 


\section{PARA AS EDUCADORAS}

A categoria trabalho foi fortemente discutida, tendo permeado todos os encontros da oficina. As educadoras trouxeram aspectos concretos e reflexões acerca do cotidiano.

\section{- As educadoras e o trabalho}

\section{Caracterização das educadoras}

Nesta apresentação, foram consideradas as 9 educadoras que participaram de todos os encontros da oficina. A idade das educadoras variou de 23 a 42 anos, sendo a média em torno de 32 anos e a mediana 31 anos. Três destas tinham formação de ॥ Grau completo, modalidade magistério, 4 curso superior completo (pedagogia, psicologia e sociologia) e duas curso superior de pedagogia incompleto.

O tempo de trabalho das educadoras nas creches da USP variou de 2 a 10 anos, sendo que apenas duas tinham menos de 4 anos e as demais (7) acima de 5 anos de vínculo.

A aproximação com a profissão foi, para a maioria delas, casual, decorrente de contingências. Metade do grupo, diante da necessidade de fazer uma opção quando da entrada para o Iำ Grau (hoje ensino médio), entre o curso de magistério e outras possibilidades existentes, foi incentivada pela mãe a seguir o magistério. Ainda que não vissem com entusiasmo essa opção, resolveram seguir o conselho da mãe. Houve também situações em que a oportunidade de trabalhar levou as educadoras a vincularem-se a uma escolinha ou creche, também incentivadas pela mãe ou pai, ainda que não considerassem uma boa idéia. Apenas duas participantes manifestaram que desde criança gostavam de "brincar de escolinha" (uma delas) e de "cuidar de crianças" (a outra).

Pode-se dizer que o início precoce, ainda durante a adolescência, foi uma das razões para que essa opção tenha sido casual uma vez que, nessa época, a pessoa está em fase de definição da identidade. É ainda marcante a influência familiar, no sentido de estimularem as filhas a seguirem uma profissão tradicionalmente feminina. 
Além disso, os relatos revelam que não havia exigência de formação específica nem experiência para o trabalho. Até a promulgação da Lei de Diretrizes e Bases da Educação Nacional (LDB), em dezembro de 1996, não havia qualquer deliberação legal acerca dos profissionais que atuavam em creches. A inclusão da Educação Infantil junto ao Ensino Fundamental e Médio, compondo o Ensino Básico, configura-a como um nível de ensino. Assim, ela passa a ser regida pelo sistema de ensino, e, conforme compete à $L D B$, o perfil dos profissionais da Educação Infantil passa a ser o do professor:

Art. 62. A formação de docentes para atuar na educação básica far-se-á em nível superior, em curso de licenciatura, de graduação plena, em universidades e institutos superiores de educação, admitida, como formação mínima para 0 exercício do magistério na educação infantil e nas quatro primeiras séries do ensino fundamental, a oferecida em nível médio, na modalidade Normal.

Em 1993, o Ministério da Educação e do Desporto definiu, em sua política de formação do profissional que trabalha com crianças de 0 a 6 anos, dentre outras, a seguinte diretriz:

"Condições deverão ser criadas para que os profissionais de Educação Infantil que não possuem qualificação mínima, de nível médio, obtenham-na no prazo máximo de 8 anos". (Ministério, s/d)

Quanto à experiência de trabalho anterior em outras creches, seis educadoras a tiveram. As demais (3) atuaram somente nas creches da universidade, sendo que uma destas trabalhou anteriormente numa creche que, embora fosse de uma unidade da USP, não era vinculada à Coseas.

As expectativas em relação ao trabalho mencionadas foram: aprimorarse como educadora infantil (4), que a profissão seja valorizada (2), trabalhar na sua área de formação - psicologia (1), trabalhar na formação de educadores (1), ter experiência com crianças de outras faixas etárias além do berçário (1).

Quanto à identificação familiar, 5 vivem com o marido, apontados como o chefe da família e, destas, 3 têm filhos; outras 3 vivem sem companheiro e têm filhos, sendo duas chefes de família e uma mora com os pais (tendo referido ser o pai o chefe da família); uma não tem filhos e mora com os pais e irmãos.

Em relação à participação comunitária: 7 participam na igreja, duas em escola, uma no trabalho e uma não respondeu. 
Atividades nas horas de folga: 8 lêem, 7 assistem televisão ou vídeo, 5 vão ao cinema, duas referiram festas, passeios a parques e exposições, uma pratica esporte e uma é radialista na comunidade do bairro.

O hábito de leitura corresponde a: leitura diária - de jornal (5), de livros (4), de revistas ou gibis (3); leitura esporádica - de jornal (2), de livros (4), de revistas (Veja, Isto é, ou Época) (5), de textos relativos ao trabalho (2).

\section{Características do trabalho realizado}

A realidade de trabalho nesse local mostra-se bastante diferente das experiências profissionais anteriores para as (6) que já haviam trabalhado com educação infantil, num sentido positivo, o que pode ser a razão do longo tempo de vínculo das educadoras às creches. A esse respeito, expressam que se sentem conquistadas pelo trabalho nas creches universitárias.

A creche da USP é muito diferente de uma escolinha. Muitas vezes a gente se cansa, fala vou procurar outra coisa, mas é um trabalho que acaba conquistando a gente.

Não aponta apenas a satisfação com o trabalho realizado no dia-a-dia, mas também a possibilidade de reflexão e aprofundamento sobre seu papel.

A creche da USP tem isso de muito importante, favorece muito essa discussão, da gente estar buscando quem nós somos. A gente está buscando valorizar o nosso papel de educadores, porque a gente entende que ele é muito importante.

Isso não significa que a realidade seja fácil. Ao contrário, há vários entraves e questões que precisam ser superadas para chegar a essa relação positiva com o trabalho.

Assim, independentemente de ter ou não formação em curso de magistério ou pedagogia, a inserção da educadora no trabalho com a criança é marcada pela inexperiência em relação aos vários aspectos relativos a este.

Essa afirmação é exemplificada pela situação da educadora que escolheu ir para o berçário para atender um interesse pessoal, de aprender a cuidar de criança pequena, pois estava grávida.

Eu quis berçário por que? Eu já estava grávida, ninguém sabia, eu estava de um mezinho, falei "eu quero cuidar de bebê, e eu tenho que aprender a lidar com isso, porque eu vou ter um bebê e eu não sei mexer com bebê", fui para o berçário. 
As questões suscitadas com essa situação sugerem que a educadora, além da consciência do desconhecimento e inexperiência para lidar com bebês, tem a representação de que, realmente, os papéis de mãe e de educadora se assemelham. Assim, se no pensamento comum, supõe-se que uma mulher que já tenha sido mãe teria competência para trabalhar numa creche, será que a educadora supôs que poderia viver a experiência ao contrário e, nesse caso, capacitar-se para a maternidade a partir da experiência de trabalho?

Bondioli e Mantovani (1998) explicam que, em geral, nas creches, "o educador é colocado frente à tarefa educativa, sem preparação específica nem em puericultura, nem em técnicas de intervenção didática, nem em conhecimento sobre o desenvolvimento, nem em dinâmicas relacionais entre adulto e criança e entre adultos".

Algumas diferenças sentidas na entrada da educadora na creche, foram a metodologia adotada para o trabalho educativo - construtivismo - e o agrupamento de crianças e famílias de classes sociais distintas. A aprendizagem foi o caminho pelo qual essas dificuldades puderam ser superadas e levaram ao desenvolvimento profissional. É possível inferir que houve uma apreensão a respeito do que e como fazer nessas situações.

Quando eu entrei, era tudo tão diferente de lá de onde eu vim, porque eu trabalhava com coisa tradicional, depois vim para o construtivismo, eu não entendia, parecia que elas falavam inglês, eu não entendia as palavras, uma tristeza, foi uma coisa que marcou demais a minha vida. Eu tive muito que aprender e eu continuo aprendendo até hoje e eu gosto muito da creche.

Sofri muito quando entrei porque as creches da USP atendem duas classes sociais, pessoas mais abastadas e crianças que não têm... Eu aprendi muito com isso também, como é trabalhar com os dois lados. Quando eu estava na prefeitura, a $R$. foi dar uma palestra prá gente falando sobre a importância das crianças de classes sociais diferentes, aí a gente falou "imagina, como que é isso? Tudo num lugar só, deve ter uma mistura", tanto é que a nossa diretora tinha uma filosofia de dar preferência para as crianças que realmente não tinham condições. E eu fiquei com aquela questão, quando eu fui prá lá eu aprendi muito, eu vi que é possível, como é esse trabalho, tão rico, para os dois lados; esbarra num monte de coisas, a gente não pode tapar o sol com a peneira, mas é bom.

Seja para ações pontuais, como trocar fraldas, seja para questões mais amplas como lidar com as famílias, a prática cotidiana demanda 0 
desenvolvimento de habilidades e competências que tornem a educadora capaz de realizar esse trabalho.

Aprendi muitas coisas, porque até então eu não tinha essa experiência de trocar fralda, coisas que a gente, quando é muito nova, não tem noção desses cuidados. Estou aprendendo com outra realidade, com outro espaço, são muitas relações, você tem que aprender a lidar com essas pessoas, com as famílias.

Considerando que o trabalho não é rotineiro, as habilidades e competências incluem saber lidar com o inusitado, estar preparada para decidir, fazer opções que proporcionem segurança à criança.

É difícil esse exercício de não ter uma rotina. Não estou falando de dar banho, mas do que vai encontrar pela frente: você não vai encontrar um carimbo, um número, que você sabe que aquilo é exato, mas você vai encontrar situações em que você tem que exercitar paciência, afetividade.

Precisa ter rapidez, lucidez.

Tem que ter uma bagagem de coisas que possam ser decididas no momento, de segurança, sabe, decisivo mesmo.

A própria compreensão sobre 0 trabalho se modifica à medida que 0 profissional se desenvolve e aprimora seus conhecimentos.

Tem um pouco do processo que cada pessoa está atravessando. Tem um pouco do histórico de cada um. A gente avança um pouco nesse entender o desenvolvimento da criança. Tem determinados momentos de entender o desenvolvimento da criança.

A responsabilidade pela atividade pedagógica também as assusta: manifestam sentir medo de assumir o grupo das crianças mais velhas, por causa do trabalho de alfabetização que é desenvolvido na pré-escola.

E eu assumi o pré, era o medão. O medão de todo mundo é assumir o pré. "Meu Deus do céu, a R. com aquele monte de textos, aquelas coisas. E se eu não conseguir, o que eu vou fazer? Eu não sei se eu sei”. Eu fiz pedagogia, mas na hora que você chega lá...

Ao falarem sobre o trabalho realizado, destacando o que é o cuidado, pôde-se identificar a valorização de todas as atividades realizadas junto à criança como parte do papel da educadora. Tendo em vista a função da creche de promover o bem-estar infantil, que inclui atender todas suas necessidades, as educadoras manifestam convicção acerca da importância de seu trabalho, no sentido de que ele proporciona bem-estar. 
Quando questionadas em relação a como se sentem durante a realização das diferentes atividades, não responderam sobre seus sentimentos, mas afirmaram que, segundo a maneira como interagem com a criança, as ações tornam-se únicas.

o banho é repetitivo, a escovação, o sabonete, a toalha. Mas não é repetitivo com a criança, porque um dia ele está mais alegre, ou mais triste, você quando está dando banho, está cantando ou está conversando, você está nomeando as partes do corpo, aí quando você diz "vamos lavar a cabeça" e ele põe a mão, nossa, é super legal, "passa o sabonete no corpo" e ele só passa na perna, não tem problema, ele só vai passar na perna. Quer dizer, é repetitivo o material em si, o lugar, o espaço, o colchonete, o cloro prá jogar, mas não é repetitivo com a criança, a forma como você vai fazer não é.

Aqui a educadora transforma as atividades, imprimindo-Ihes qualidade no sentido de falar sobre como elas podem ser compensadoras. Ela percebeu que é possível ensinar enquanto cuida e, por isso, não se sente depreciada em seu papel de educadora.

Contudo, para algumas, as atividades "de cuidado para o bem-estar" são separadas das "atividades pedagógicas", ocorrendo em momentos diferentes e sendo, as primeiras, uma condição necessária para o desenvolvimento das ações pedagógicas.

Ela estando limpa, bem alimentada, descansada, você está criando um ambiente facilitador para um outro ambiente de desenvolvimento cognitivo. A nossa parte pedagógica, a nossa parte de linguagem, matemática, é facilitada pelo bem-estar, ela está disponível para aprender.

É interessante destacar que esta fala resultou da discussão de 5 educadoras durante uma das reuniões, dentre as quais 4 estavam, na época, atuando junto a crianças menores de 3 anos. Depreende-se um certo privilégio aos aspectos cognitivos, com organização de conteúdos por áreas de conhecimentos, tal como nas disciplinas escolares e não se menciona articulação entre ações de cuidado e função pedagógica. Esta forma de definir o trabalho junto à criança mostra uma dicotomia entre educação e cuidado, com maior valorização do pedagógico.

A relação afetiva entre a criança e a educadora foi destacada como uma particularidade do trabalho. A afetividade surge em resposta a uma demanda da própria criança. 
$O$ afetivo tem a ver com todas as creches. Ao mesmo tempo que eles querem brincar com tudo e fazer tudo, tem hora que eles querem ficar no colo da gente, querem atenção. A questão do afetivo permeia muito nosso trabalho no módulo 1.

A afetividade foi enfatizada como a relação carinhosa, o afago, o toque, o colo, a atenção individualizada.

E, finalmente, a educadora entende que, com seu trabalho, está promovendo a cidadania infantil.

A gente está construindo a cidadania junto com as crianças, está passando prá eles esse conceito de cidadania. Não que a gente esteja explicando o que é, porque eles já nascem cidadãos, mas a gente está fortalecendo isso na construção deles.

Ainda que considerem estar desempenhando o papel do educador ao executarem as atividades junto à criança na creche, sentem certa frustração, porque identificam que seu fazer não é reconhecido como educativo.

Quando a gente discute essa coisa da escola, da educação, a creche frustra um pouco. Eu não entendo que o bem-estar não seja pedagógico, porque se a criança está aprendendo a escovar dente, está aprendendo a trocar de roupa, é um processo pedagógico. Não é uma coisa isolada da outra "agora você está prontinho, você está trocadinho, arrumadinho, então vai fazer a tarefa”, eu entendo que isso não seja isolado. Mas entra um pouco nessa discussão do papel do educador "quem somos nós”. Porque algumas pessoas, não dentro das nossas creches, mas eu já trabalhei fora, eu vejo um pouco isso "eu quero ser professor" quer dizer, o ser professor, a hora do trocar, de dar comida, ele acha que não está sendo professor, eu já vivenciei isso. Prá mim, o educador é tudo isso.

Meu amigo perguntou "você é professora, você dá banho?". Ele ficou impressionado: "mas você é professora, você limpa cocô??" "Eu limpo de criança de berçário e já limpei com 6, 7 anos também”. O cocô, o xixi, o catarro, o espirro, o pum, faz parte de tudo, a gente trabalha com pessoas, $e$ elas comem.

A educadora relata como percebeu, durante uma palestra a respeito do atendimento da criança pequena na creche, que ela sempre realizara tudo o que estava sendo descrito, mas sem ter consciência de que isso fosse uma atividade profissional, pois não havia o registro desse fazer. A referência à falta de registro mostra como as atividades em questão, com as crianças do berçário, não estão sistematizadas.

Eu assistia a palestra, eu falava "é o que eu fazia". Só que eu sei que eu fazia porque eu trabalhei no berçário, mas um registro do que está se 
falando... Se você fala que trabalha no berçário, a sociedade discrimina mesmo, "você trabalha limpando bumbum de criança".

O trabalho no berçário não é reconhecido socialmente, pois as atividades relacionadas ao corpo da criança são discriminadas inclusive por profissionais formados para atuar na área da educação.

Há uns anos atrás, eu estava trabalhando no berçário. Chegou uma menina nova, ainda na formação, foi para o berçário, prá observar. Eu a levei ao banheiro e expliquei todo o processo prá ela, situando-a no espaço. Aí, ela falou "vocês trocam fraldas?". Respondi "trocamos lógico". E ela "ai, eu não fiz pedagogia prá trocar fraldas". "Mas faz parte do processo, é um bebề". Ela ficou só esse dia, foi embora. Depois o pessoal se descabelou, "como passou isso na seleção?”.

As educadoras também identificam esse preconceito nos trabalhadores das creches da USP.

A gente vê muito preconceito. Você ouve falas, no nosso grupo de educadores. Já ouvi falas na Central. A gente ouve na Carochinha, nos encontros, e você vai percebendo a discriminação e o preconceito: "educador de módulo 1 , de berçário, não precisa de investimento pedagógico, não tem projetos, porque é o cuidar"; "eи não vou trabalhar no berçário, no berçário a gente só troca fralda, tem que dar mamar, tem que limpar bumbum". Não vê isso como parte do processo de educação mesmo. A gente vê muito isso, você ouve falas de pessoas que já estão há bastante tempo na USP "trabalhar no módulo 1? Não tem projetos e eu sou educadora".

Isto é confirmado na fala de uma das participantes, ao afirmar que seu trabalho só começa a ser visto com as crianças maiores.

Eu passei pelo G1 e G2, é um grupo que realmente inclui a questão dos cuidados. Eu acompanhei esse mesmo grupo que era uns toquinhos de um ano ou dois. Depois, acompanhei eles no G3. E aí você começa a ser olhada, o seu trabalho. Aí eles já estão configurando um desenho, uma roda de conversa, já estão dialogando mais, [pode] colher mais dados deles, por onde seguir...

E, como disse uma das educadoras, "se isso acontece nas creches da USP, que está combatendo" esse preconceito, "o que dirá fora de lá".

\section{O impacto do trabalho sobre as educadoras}

O grupo que participou da investigação foi unânime quanto ao sentimento de realização profissional, por gostar do trabalho e perceber-se desenvolvendo seu potencial. 
Eu me sinto bastante realizada, por ser educadora, apesar de não ser ainda reconhecida, mas a gente está buscando reconhecimento.

Também adoro, é um trabalho bem legal, e não pretendo deixar de trabalhar com a educação.

Gosto muito, o trabalho da creche é muito bom, estou aprendendo muita coisa. Já me defini, quero trabalhar na educação, não necessariamente na educação infantil, trabalhar com formação.

O resultado do trabalho se verifica não só em termos de produto obtido com as crianças, de seu aprendizado, mas também no desejo das crianças de estar na creche, mostrando que é uma experiência feliz para elas. Isto gera sentimento de gratificação para a educadora.

A gratificação de ser educador é sentir esse respaldo: nós tivemos esse período da greve, e uma semana de férias, e teve criança que emendou. Apesar desses pontos negativos, quando a gente encontra uma mãe, ela comenta "ele não vê a hora de voltar". É importante isso prá gente também, as crianças voltam com saudade, com vontade de voltar prá creche. Tem crianças que a gente até ri, a mãe fala "se você não se comportar você não vai prá creche", a criança "quer morrer". É interessante isso. Apesar das dificuldades, tem sempre um ponto positivo.

Essa semana, eu tive uma visita de um aluno do ano passado, a mãe dele disse "ele queria tanto ficar com você, será que o meu filho pode ficar no seu grupo? Você era educadora dele o ano passado. Tem algum problema?". Respondi: "Não, não tem problema, você traz ele na terçafeira, eu vou avisar o grupo também". Você vê que tem essa lembrança, eles saem da creche, mas querem voltar, querem ver os amigos, querem brincar, enfim, tudo muito legal.

Por isso, reconhecem que a despeito da identificação de problemas e dificuldades, a ênfase no resultado do trabalho exprime o que é mais importante para elas: a avaliação é positiva quando verificam estar atendendo às necessidades da criança e da família e cumprindo os objetivos propostos. Isto traz sentimentos de paz, prazer, felicidade e de realização.

Quando a gente está relatando, esquece as dificuldades. Esquece porque o resultado é muito mais marcante.

Outubro, novembro, as crianças já estavam lendo, a maioria. Tinha aqueles que, sei lá, alguns fatores que não deixou isso acontecer, mas as crianças já estavam com gosto pelos gibis. Foi muito bom ver essa produção.

Eu só estou vendo bebê na minha frente, porque esse ano estou voltando para o berçário. Mãe feliz, criança feliz, educadora feliz também, porque está vendo que o trabalho está dando certo.

As pessoas ficam felizes quando o trabalho está bom, está dando certo, a gente precisa mesmo andar juntas sempre, prá poder estar trabalhando com 
as crianças. As pessoas ficam felizes de ver como o trabalho está bom mesmo.

[Um] sentimento de paz, que é muito forte, de ver que a criança está bem, se sente bem estando com a gente; e a gente também, de estar ali naquele grupo, fazendo um trabalho que vai favorecer o desenvolvimento dele. É um sentimento bom, a criança está perto da gente, perto de tudo que a gente pode oferecer a ela, carinho, cuidado, respeito, afeição, educação.

Há situações em que o resultado supera expectativas, como no caso relatado sobre uma criança com necessidades especiais, ocasionando sentimento de vitória para as educadoras.

O médico disse "a gente não sabe o quanto ela vai viver, o que ela vai fazer", e a gente fala assim "N. come", e ela faz "uh, uh, uh". A gente fala "dança" e ela se movimenta. E o médico falou que ela talvez não levantasse nem a cabeça sabe? O médico falou que ela não ouve, não enxerga e quando um grupo está ali brincando, cantando e gritando, ela se vira para o grupo e grita porque ela está participando também.

Há outras fontes de reconhecimento que geram satisfação: a avaliação das coordenadoras, o interesse da comunidade externa, particularmente profissionais da educação e pesquisadores, que se reportam à qualidade das creches da USP e, por conseqüência, à competência profissional das educadoras.

O lado positivo do nosso trabalho, é todo o tempo estar sendo visto, estar sendo observado, seja por pesquisadores, pelas chefias imediatas, seja pelos pares, por nós mesmos, pelas crianças; a gente está sendo olhado, está sendo vista por nosso trabalho. A USP, o trabalho das creches na USP, é assim: "nossa, você trabalha na USP?". Essa semana que eu trabalhei fora, no SESC, me perguntaram: "como você conseguiu trabalhar aqui?". Respondi: "é que eu trabalho na USP". A pessoa falou: "ela é educadora da USP! Fala prá elas como que é o trabalho, são alunas de magistério". A gente é visto, é reconhecido.

Nessas circunstâncias, as educadoras percebem-se "diferentes": o trabalho na USP proporciona maior qualidade na formação e um conseqüente sentimento de competência profissional. Isso se dá particularmente em relação à situação de lidar com as crianças.

É uma facilidade saber como chegar perto de uma criança. Porque eu posso dizer que eu posso chegar perto de qualquer criança, eu não sinto "aquela criança é meio arredia", tem adulto que fala "tem criança que eu não suporto". Isso é uma facilidade do meu trabalho: eu chego perto de qualquer criança, me agacho, prá conversar, "oi, quem é você?". Isso é uma facilidade do meu, do nosso trabalho. 
Esse sentimento de competência leva-as a vislumbrar outras possibilidades de trabalho, ressaltando o desejo de empregar seu conhecimento para a melhoria da situação de populações mais necessitadas.

Eu posso difundir essa bagagem que eu tenho na USP, passar prá frente. Eu tenho como meta, tanto na minha área de sociologia, que é uma coisa que eu gosto muito, e na área de educação infantil propriamente dita, na parte pedagógica, unindo essas duas coisas, eu pretendo trabalhar com formação, e passar isso prá frente, e principalmente prá classe que não é tão abastada; é uma forma de ir transformando, a educação é uma transformação.

Eu quero trabalhar com criança carente, sei lá, projeto de rua, expandir esse conhecimento que eu adquiri na USP para os outros que são desfavorecidos e que vai ser difícil ter esse mesmo acesso, essa mesma informação, não sei como, não sei nem por onde começar, mas eu tenho essa idéia de trabalhar mesmo com criança carente.

Um último aspecto relacionado a características do trabalho referiu-se à falta de reconhecimento que se evidencia nos baixos salários e na falta de perspectiva de progresso na carreira.

E a parte financeira: se a gente é tão visto [valorizado], por que não ser reconhecido financeiramente, por que a gente ganha pouco? Em termos da qualidade do nosso trabalho, e do tamanho que é a Universidade, o educador ganhar o que a gente ganha, não dá prá manter a família, não dá. A gente também não vive só de amor, de gostar, a gente precisa viver e viver bem, razoavelmente, com um salário digno.

As educadoras reclamam de uma situação que, sabidamente, não se restringe à creche, pois, similarmente, os profissionais de todo o ensino público não têm sido reconhecidos, no que diz respeito, principalmente, à remuneração por seu trabalho.

Assim, é compreensível a realidade em que se encontram os trabalhadores das creches, uma vez que até muito recentemente estas eram reconhecidas como serviço cuja função nada mais incluía do que guardar e alimentar crianças cujos pais não podiam fazê-lo adequadamente.

Contudo, hoje já se reconhece ser fundamental que a creche alcance um patamar de qualidade que responda ao conhecimento acumulado sobre a primeira infância (características e necessidades próprias de um desenvolvimento intenso), ao número crescente de crianças que freqüentam esses serviços e ao grande número de horas que elas passam na creche 
(Conselho, s/d). Partindo do reconhecimento de que a natureza fundamental da creche modificou-se e, portanto, tornou-se necessário "buscar mais atentamente a melhor forma de cuidar das gerações mais jovens naquele que se tornou um dos ambientes mais comuns do aprendizado da primeira infância - a creche de período integral", a Austrália desenvolveu um Sistema de Promoção de Qualidade e Credenciamento para as creches daquele país. O exemplo australiano baseia-se num fato incontestável nos dias de hoje: se desejamos construir uma base sólida de cuidados e educação de alta qualidade para nossa população infantil, é mister investir na qualidade da creche.

No que respeita ao reconhecimento profissional, é quase uma luta instituir uma nova concepção sobre o valor monetário desse trabalho, pois, em nosso meio, há um juízo corrente de que os profissionais da educação, assim como os da saúde, exercem um trabalho assemelhado a um sacerdócio. E a idéia de vocação, ou dom, não coaduna com a idéia de reivindicação salarial.

No que diz respeito à carreira, foi expresso que há falta de incentivo aos funcionários, para progressão acadêmica, seja por não diferenciá-los quando realizam cursos de graduação e pós-graduação, seja por não facilitar o acesso a tais cursos na Universidade.

Quando você faz sua livre-docência, seu doutorado, tem uma gratificação, e o funcionário comum não tem. Só tem prá função de docente...

A gente trabalha dentro de uma universidade, e apesar do nosso trabalho não estar inserido junto com o papel da universidade que é o de estudo e pesquisa, nós deveríamos ter um facilitador de acesso para formação. Às vezes, eu escuto "você trabalha na USP, tenta uma bolsa lá, consegue estudar lá”. Não é assim... Porque não? Numa outra empresa, ou mesmo na Prefeitura de São Paulo, você consegue ter um acesso muito mais fácil do que na própria universidade... Então, tem que fazer com os funcionários primeiro. Competir com quinhentos filhinhos de papai, que fazem cursinho nos Estados Unidos, para cursar os melhores cursos da Universidade, é complicado.

\section{- A organização do trabalho •}

Tal como descrito para as coordenadoras, é marcante a característica de organização do trabalho realizado, mediante o planejamento conjunto de atividades, considerando conteúdos, objetivos e metas, tais como o 
estabelecimento de rotinas e o desenvolvimento de projetos. Destaca-se ainda a integração da equipe, indispensável, pois se trata de um trabalho que não se completa individualmente.

A rotina, a maneira de organizar e distribuir o tempo para as atividades diárias a serem realizadas com as crianças, foi apresentada como algo comum às 3 creches, com algumas diferenças, particularmente em decorrência de suas realidades quanto a espaço físico.

A creche da Saúde é um espaço bastante pequeno, então vai mostrar essa rotina de uma outra forma, diferente da creche central, onde a gente consegue marcar alguns espaços.

Lá nós trabalhamos de uma forma diferente, que é a oficina coletiva, as crianças passam por todos os educadores. Foi uma tentativa de implantar essa oficina e cada ano a gente vê que pode melhorar nisso e o ponto mais importante é a coletividade, a interação entre as crianças, independente de faixa etária, porque todos conhecem todos, todos sabem os objetos de todos, todos sabem que nós somos educadoras deles. Tem as dificuldades também, que são grandes, preparar atividade prá todas as faixas etárias, mas principalmente esse momento de interação de manhãa que eles chegam perguntam "fulano chegou? Eu cheguei primeiro" e, nessa interação, eles brincam, conversam, contam. Depois que é feita a dinâmica, na divisão das oficinas.

Porém, mais do que diferenças nas rotinas, as limitações do espaço físico perturbam a execução das atividades.

Todo mundo fala "é um número pequeno de crianças", mas o cansaço que você sente, o barulho, fica muito na cabeça da gente, porque o espaço é muito pequeno. Ainda até relatei para as meninas na central que a gente não sente isso na central. Apesar de eu ter um grupo de 15 crianças, eu não sinto esse barulho todo. Tem o cansaço físico, de toda a rotina, a troca de fraldas, adaptações, mas a gente não sente esse cansaço do ouvido, de ficar todo mundo muito preso, num local só, a gente não tem essa experiência lá. A diferença de espaço e até a qualidade de trabalho para o educador. É importante isso.

O espaço é muito precário e isso desgasta muito o educador. Nós somos em 4 educadores agora, e o quadro de crianças de 22. Quando eu relato prá alguma amiga, fala "nossa, mas que creche". Mas você só se dá conta mesmo da rotina, do trabalho que é, estando lá, por conta desse espaço mesmo, que você tem que estar policiando o tempo todo, para ir ao banheiro, para ir lavar as mãos, organizar sempre o espaço prá rotina poder fluir, controlando as crianças toda hora, "não pode correr".

Com relação ao planejamento, enfatizaram as atividades pedagógicas, os projetos desenvolvidos para a aquisição de conhecimentos específicos. 
A preocupação em experimentação de todos os materiais, visando um conteúdo que a gente planeja. Tudo isso centrado no desenvolvimento da criança como um indivíduo crítico, como um indivíduo autônomo, independente.

A gente desenvolve projetos. No módulo 2, temos um projeto de ciências naturais, atualmente estamos trabalhando com as formigas; incentiva a pesquisa...

Dentre as funções que competem à educadora, não se inclui administrar medicamentos, o que é enunciado como um fator muito positivo da organização do trabalho.

Quando eu cheguei na creche, ouvi "aqui você não mexe no remédio, porque tem uma enfermaria". Eu não acredito que existe um lugar assim. Eu achei fantástico a gente não ter a responsabilidade sobre essa parte que é muito séria.

A estrutura do trabalho se estabelece sobre uma base coletiva, sendo inviável individualmente. A metáfora da engrenagem fala sobre a sintonia, a harmonia entre os fazeres das pessoas na creche, na busca de realizar 0 mesmo propósito de trabalho.

Aqui são pessoas que estão numa mesma sintonia e numa engrenagem, o trabalho também caminha, numa mesma linguagem.

O nosso trabalho na creche tem que ser muito ligado uma com a outra, é um trabalho em equipe mesmo, tem que ser muito coletivo, toda hora, todo dia, todo minuto, sempre.

Depende muito da sua parceira, porque prá você desenvolver um trabalho na creche você não faz sozinha. Você tem que ficar o tempo inteiro conectado com a parceira. Se você fala A de manhã, sua parceira fala B à tarde, no outro dia você vai encontrar $C$, porque se não falar a mesma língua, não segue o trabalho.

Os aspectos da cooperação e organização são enfatizados ainda mais em relação ao trabalho no berçário, apontado como requerendo maior cuidado em comparação ao realizado junto às crianças maiores, em função de necessidades específicas como higienização de ambientes e objetos.

$O$ berçário acaba sendo muito fechado, pela necessidade do trabalho. $O$ cuidado que você tem com a criança do berçário não é o mesmo que você tem com a criança do G2, do G3. Tudo é pensado nos mínimos detalhes, um brinquedo caiu no chão, esse brinquedo tem quer ser tirado do berçário porque tem que ser lavado, saiu da boca de um, você tem que tomar cuidado.

Eu sou uma pessoa um pouco desorganizada, e o berçário não. O berçário tem que estar sempre com as coisas prontas, no lugar, e fácil, limpas. Você 
não pode sair no seu horário sem deixar os brinquedos lavados, porque o pessoal da tarde vai usar. Tem que ter uma divisão de tarefas, todo mundo tem que saber, dosar, e tem que ter cooperação.

Sobre esse assunto, Ghedini (1994) afirma:

"o planejamento educacional é um método de trabalho que evita ações aleatórias e a esmo (através de definições específicas de objetivos educacionais, instrumentos e critérios de acompanhamento). (...) O serviço funciona bem quando os trabalhadores podem coordenar suas atividades e cooperar uns com os outros".

O resultado do trabalho com a criança depende da continuidade e do compromisso de cada educador

Também aparece muito a gente. Se o educador do berçário começou um trabalho, então o papel de dar continuidade a esse trabalho é dos outros educadores, que vão pegar essas crianças nos outros grupos. $O$ que começou no berçário reflete lá no pré, porque teve uma continuidade, mas depende também muito da gente querer e pegar na mão.

Não só os educadores desempenham um papel importante. Cada trabalhador tem uma função importante na creche e precisa assumir suas funções, para que o trabalho se concretize.

Tem várias linhas, simbolizando a família, a instituição como um todo, pensando em todos os segmentos, na psicóloga, no pessoal de apoio, em todo mundo. Porque todo mundo faz a creche, não é só o educador, todo mundo é importante prá que esse tipo de educação aconteça, porque o nosso trabalho não vai acontecer se tiver a cozinha suja, se não tiver quem faça a comida, não tem como você pegar uma vassoura no meio das crianças e estar fazendo esse trabalho.

Não é uma coisa departamentalizada. Ainda que a gente diga para o pai procurar a psicóloga para conversar, porque é uma coisa que compete mesmo a um psicólogo, porque nós chegamos ao nosso limite. Mas tem questões que são universais. Por exemplo, a coisa da mordida. O pai chega na creche "meu filho tomou uma mordida eu vou procurar a M. [diretora]". "Não. Não precisa, a gente pode estar respondendo". Ou do palavrão, por exemplo, "chamaram meu filho de filho da puta" que é uma coisa super comum entre as crianças. É uma coisa que dá prá gente discutir. Eu e o pai, porque é uma coisa que não é a diretora que vai ter a resposta prá isso porque é uma resposta universal, quer dizer, o palavrão é ruim em qualquer lugar. Tem coisas que dá prá gente responder, não precisa a diretora responder, mas tem coisas administrativas que só ela vai poder responder mesmo.

A educadora espera ter autonomia em alguns aspectos, mas tem expectativas quanto ao papel da coordenação que se refere tanto a resolver 
questões de sua competência profissional como para impor limites a comportamentos indesejados dos pais.

[tem pai que vem pegar a criança bêbado] a coordenação tinha que dar um limite, ela não serve só prá entender a parte psicológica e pedagógica, mas também limites de autoridade direta. Por exemplo, a creche fecha seis horas, não cabe a nós falar, olha seu filho não entra mais, cabe à elas falar: "a partir de 3 intercorrências de horário não dá prá você entrar mais”. E também com relação às regras de funcionamento da creche, chegar dez horas, dez e meia da manhã, tem uma justificativa.

Há uma avaliação positiva sobre a coordenação, ao afirmarem que esta age de maneira imparcial quando há conflitos entre as educadoras e a família.

A coordenação não tem uma verdade só, por exemplo, ela fala para o pai "é o senhor realmente tem razão". Não, elas falam "a gente vai estudar melhor isso". Então ela ouve o pai, ouve a nós, procura observar um pouco e dar esse retorno para o pai porque ele está querendo, isso é muito bom. Não tem só a verdade do pai e também não tem a verdade só nossa. Ela ouve os dois lados.

O registro das atividades é um instrumento para a reflexão sobre o trabalho:

Cada situação que a gente vai registrando é importante para o trabalho, não só na escrita, como na fotografia, que a gente depois olha e lembra do que aconteceu com determinado grupo e a gente pode estar refletindo sobre aquele trabalho prá inserir de uma outra forma, porque a gente está hoje com um grupo mas amanhã a gente está com outro.

A importância do registro das informações dá-se porque, através dele, as observações não se perdem e podem ser utilizadas como instrumento de trabalho, uma atividade profissional, possibilitando planejamento e avaliação (Ministério, 1998).

\section{Dificuldades relativas ao trabalho na creche}

As dificuldades relacionadas à organização do trabalho decorrem, principalmente, de questões peculiares ao trabalho em grupo, tais como as diferenças individuais entre as educadoras, que constituem obstáculos à interação efetiva quando não são solucionadas.

Todo trabalho coletivo, a gente sabe que é difícil, por vários fatores, de pensamentos diferentes, de sentimentos diferentes. Na hora das pessoas sentarem e conversarem, às vezes elas têm muitas diferenças e a gente sente muito isso, a gente está procurando dar o melhor da gente e a pessoa, ao invés de falar alguma coisa prá ajudar, corrigir, para te orientar de alguma 
forma, a pessoa fala uma palavra que te desmonta inteiro. Eu também sinto essa dificuldade do coletivo, por melhor que o grupo seja, dá sempre para a gente estar melhorando.

Ninguém é igual, ninguém é formatado. Mas é muito difícil você escutar e conseguir se colocar longe e fazer uma mediação, ser mediadora, dentro de uma idéia crítica, dentro de uma situação crítica.

As educadoras salientam a contradição entre a proposta de ensinar as crianças a conviver em grupo compartilhando e respeitando os colegas e o trato diário junto às educadoras que nem sempre se mostra dessa forma. Considerando o exposto anteriormente, acerca da base coletiva do trabalho, é imprescindível que as relações sejam mais amistosas e cooperativas.

O coletivo, é difícil essa relação, está todo mundo junto, mas nem sempre é um grupo. A gente trabalha com diferenças e com interação, não só no grupo de crianças, mas no grupo de educadores, dos adultos, e isso parece ser tão fácil e às vezes está tão longe da gente. A gente fala prá criança: "você tem que trocar o brinquedo com seu amigo, dividir, agora você brinca, daqui a pouquinho dá para o outro", e exige da criança que ela consiga essa relação de compartilhar tão fácil quando você não consegue compartilhar uma idéia. Você leva para as crianças um ideal, uma idéia, um exercício, que está tão difícil de você conseguir fazer esse exercício, é uma das grandes dificuldades que a gente tem, esse relacionamento, é trabalhar com essas diferenças.

A pessoa é capaz de não gostar e até criticar, mas nunca de ajudar, de falar assim: "Olha, eu posso te ajudar? Eu pensei desse jeito, vamos ver se a gente acha legal, se fica melhor ou não". E a gente cobra isso das crianças. Esbarrou no amigo, desculpa, mas não é só pedir desculpa. Vai lá, ajuda, levanta, vê se ele machucou, mas às vezes a gente é incapaz de fazer isso.

E não é só pedir desculpas, é olhar para o outro, "desculpa", a gente mostra isso para a criança. Você tem que olhar para o teu amigo, porque é fácil falar "desculpa". E às vezes a gente faz isso com o nosso colega. As situações não foram resolvidas e aquilo acaba virando um distanciamento.

A respeito da experiência da elaboração coletiva do conhecimento, levada a cabo durante a construção do projeto pedagógico da Creche Central da USP, Dutoit (1995) descreve-o como complexo e revelador de contradições, e cita Makarenko dizendo que "a coletividade é um mar de personalidades, sem limites, cheio de flutuações".

O fato de constituir um grupo de trabalho não leva obrigatoriamente a resultados positivos. Para trabalhar em grupo, além das habilidades diferentes, competências específicas e um conhecimento recíproco dessas habilidades e competências, precisa-se de um elemento que é confiança. As relações de 
trabalho são permeadas por uma série de outros elementos que nem sempre ajudam a ter confiança, diálogo, e, por isso, a colaboração que se ensina, nem sempre é aquela que se exercita.

Outra dificuldade referente à forma de organização do trabalho é assumir a função de volante.

Ser volante incomoda. O volante na creche é aquele educador disponível, ou seja, se faltar a I., eu tenho que estar no lugar dela prá receber a criança, independente se eu não sei o que ela planejou naquele dia. Eu tinha que olhar, mas será que vai ser do mesmo jeito, eu dou ou não dou, espero ela chegar? Se alguém "pede as contas", a volante assume. A volante tem sempre a sensação de "eu não faço nada, eu tapo-buraco".

[Se falam] "como aquele grupo está legal, desenvolvendo bem", nunca [o mérito] é a volante; a volante está dando retaguarda para todos os educadores, mas ela não aparece, ela é invisível. Mais invisível do que todos.

É uma carta fora do baralho. Uma reunião de dupla, a educadora da manhã e a da tarde, a volante sai fora. A volante tem que estar ligada o tempo todo no que está acontecendo, mas ela só entra em ação a hora que o buraco está vazio. O trabalho da volante parece que nunca aparece. Falam [para a volante] "desenvolve um projeto, pensa num projeto de ateliê prá você construir", você começa um projeto e "hoje faltou a S.", você tem que cobrir, porque a S. não está. Tem cobrança, porque chega na avaliação de desempenho "seu projeto ficou a desejar um pouco".

No caso de assumir a função de volante, a pessoa fica privada de realizar as atividades pelas quais reconhece seu trabalho, suas competências didático-educacionais, que constituem, conforme expõe Bonomi (1998), a imagem consciente de seu profissionalismo.

As dificuldades de trabalhar com as crianças menores centram-se na dependência física e emocional que a criança tem em relação ao adulto. Assim, o trabalho no berçário é cansativo, causando grande desgaste no trabalhador. Além disso, há tarefas desagradáveis, como a troca de fraldas e o trabalho não é reconhecido socialmente.

O trabalho é difícil, fisicamente, principalmente quem trabalha no módulo 1, que é uma coisa muito corporal, bem física, pega a criança no colo, troca, levanta, a cuba é alta, tem crianças que pesam 10, 12 quilos, e você tem que tirar ela do chão, colocar para trocar, depois pôr na cuba, tirar, devolver, isso às vezes 3, 4 vezes, porque ela faz xixi, ela faz cocô, você tem que lavar, dar banho; e quando termina o dia, a semana, você está acabada mesmo. 
No berçário, fora a discriminação em relação ao trabalho, o desgaste do educador é muito maior. Fisicamente desgasta muito mais mesmo. Porque a criança depende de você. Você que vai estar sempre assessorando, em relação a toda a higiene, e fora todo o processo de uma rotina que você vai ter que desenvolver. Além de não ter o reconhecimento, ainda tem esse fator a mais.

É desagradável? É. Você sentir cheiro de cocô todo dia, toda hora, criança tem diarréia, no chão, na meia, é luva que você tem que pôr.

Mas o desgaste não é só físico. Para construir o vínculo emocional necessário para o estabelecimento de confiança, as educadoras precisam disponibilizar-se ao envolvimento. Há um desgaste emocional que advém desse investimento para cativar a criança.

Tem que ter um preparo psicológico muito grande também, porque, a maioria das vezes, você é a primeira [após a] separação dos pais prá criança, você é o primeiro contato externo, sem ser avó, tio, alguém que faz parte da família, que a criança tem. E o vínculo que você cria com a criança é tão forte, porque a mãe te entrega a criança, de manhã, e quando a criança te aceita, ela consegue criar com você um vínculo, é muito importante porque ela é dependente. Criança de berçário é muito dependente, é dependente afetivamente, fisicamente. E, às vezes, prá você construir a relação, é muito desgastante.

Aquela criança que chega na adaptação berrando, que fica das sete até as nove e meia, dez horas... Você sai, você balança, você chacoalha, dá para outro quando você não está agüentando, "não agüento mais ouvir o choro dessa criança, eu vou lá na frente tomar um café, você fica um pouco".

Manifestaram um conflito vivido diariamente, nos momentos da higiene.

É como se as funções de educadora e cuidadora, nessa situação, trouxessem um paradoxo: ou as crianças fazem sua higiene sozinhas, para aprender, apesar de molharem as roupas (resultado indesejado) ou são cerceadas na forma de realizá-la (intervenção imprópria), garantindo que não se molhem.

A questão da higiene, o momento do banheiro, de lavar as mãos, de escovar os dentes, é um momento bastante conflitante para todas nós. Ao mesmo tempo em que a gente entende que eles precisam fazer sozinhos, que eles estão aprendendo, tem a coisa de não se molhar. Tem criança que traz pouca roupa na mochila, a gente fica "você não trouxe muita blusa, então não vai se molhar". É importante fazer a higiene, é o bem-estar dela na creche. Mas a gente tem que estar atento se tem outra roupa. E elas ficam com aquele olharzinho "é para fazer, ou não é para fazer? Eu posso ou não posso?"

O espaço físico restrito, limitado, gera sentimento de frustração para com o trabalho, pois impede a realização das propostas da educadora. 
Quando está insatisfeito, quando o trabalho não caminha do jeito que se quer, porque às vezes a gente planeja uma série de coisas e, por causa do espaço, acaba não acontecendo e o quanto isso frustra a gente.

Tem as dificuldades, a parte ruim: está me irritando aquele pátio, está muito ruim mesmo, está desagradável, aquele frio cortante, é tanta roupa que eles não conseguem nem se movimentar direito.

No dia-a-dia, outra dificuldade é a restrição imposta pela instituição quanto ao consumo de alimentos da creche.

Tem uma dificuldade, na creche, de comida: a gente pode degustar, mas não comer. É complicado, como a gente vai estimular uma criança a estar experimentando um alimento, se nós mesmas não podemos?

Na creche tem isso, pegar um pedacinho. Mas a gente faz seis horas de trabalho, chega na hora do almoço, fica sentindo o cheirinho daquela comida toda, você passa mal; grávida então, o bebê mexendo você "filhinho se acalma”, é dureza.

A gente sabe que pode estar degustando, experimentando, mas de repente você está com um bolo e vem uma pessoa e vê. Você engole, aí você fala "estou degustando". Quer dizer, você não precisa explicar que você está degustando, para não dar a impressão que você está comendo escondida.

\section{A realidade das creches é diferente:}

Nós estamos com três creches e as nossas realidades são diferentes, mesmo sendo creche USP. Eu me sinto privilegiada por estar na creche Central, a gente recebe palestrantes que elas não recebem. Então tem que se fazer ainda um investimento maior na própria creche USP. Existe uma coisa por ser creche USP, mas não é tudo isso, porque existe divisão e isso foi posto aqui, acabou aparecendo as diferenças. Por mais que a gente tenha predisposição de fazer o trabalho, ainda tem que se investir mais nas creches. Porque tem uma mais privilegiada do que as outras.

\section{Falta troca entre as creches:}

Apesar de serem três creches que pertencem à mesma instituição, a filosofia é a mesma, a gente não conversa, não troca informação, para saber o que está sendo feito em cada creche, a conduta de como se organiza o trabalho, igual a esse momento que nós estamos tendo aqui. Eu vou começar um projeto na creche, só que a outra creche já fez, e poderia me dar uma orientação, já que é a mesma instituição. [Há] dificuldade de interação do grupo, que as pessoas possam se reunir, discutir e ver onde é que tem os defeitos prá estar se reorganizando, melhorando. 


\section{- A formação para o trabalho na creche •}

Conforme já foi dito, as educadoras percebem-se "diferentes" em relação aos profissionais em geral e isso se deve, em grande parte ao trabalho de formação realizado nas creches da USP.

A formação em serviço é uma troca de experiências e conhecimentos que torna mais consistente a atividade profissional, é um processo de apropriação do conhecimento e reflexão sobre a prática.

Quando a gente faz a formação dos educadores, eu entendo que nós estamos compartilhando a nossa experiência do trabalho. Não é uma coisa que só a pedagoga vai ter uma linha prá estar passando. Cada uma de nós tem prá dar uma prá outra, por conta da experiência do trabalho. Então é uma troca. Eu vou dar de mim, ela vai dar dela, e vai ter coisas que a gente tem que ouvir da pedagoga porque ela tem uma especialização.

Falei "não sei se sei, vou procurar fazer o melhor que eu puder" e fui. Quando eu peguei essa turma do pré, eles não sabiam fazer ó com có, e fui fazendo, ficando depois do horário para planejar, aquela coisa toda, "desse jeito não dá, vamos pensar de outro jeito, esse grupo é muito difícil, o que eu faço com aquela criança, eu preciso de alguém? Não, eu não preciso".

Campos (1994) ressalta que, mesmo nos países e regiões em que a competência do professor já existe em decorrência de uma formação prévia apropriada para a educação infantil, é necessária a formação permanente em serviço, sendo que:

"Essa formação é entendida como um processo amplo e diversificado, onde os momentos de planejamento e avaliação em pequenos grupos ou em duplas, os contatos com a coordenação pedagógica, as tarefas individuais de observação e registro, as ocasiões de discussão em equipe, de relatos de experiências para as famílias e outros públicos, propiciam o amadurecimento dos educadores e, até mesmo, a construção coletiva do currículo".

A efetividade do processo de formação aparece na explicitação da introjeção do aprendizado sobre o trabalho na creche, que leva à mudança real das educadoras.

Se eu tivesse um bebê agora eu seguiria a creche. As minhas filhas, elas foram assim... do jeito que é a casa mesmo. Eu dava café com leite quando ela tinha um ano, eu aprendi muito com isso.

Cipollone (1998) afirma que o processo de profissionalização do trabalho do educador passa por "entrar em contato com as práticas educacionais existentes na família e no social e confrontá-las com saberes mais eruditos". 
Esse processo faz-se necessário para superar o saber "subjetivo" que a educadora traz, construída na sua história de vida.

"A passagem de uma operatividade vista como natural, para uma outra colocada em bases científicas, passa pela capacidade de perceber, escutar, documentar, utilizando técnicas de pesquisas que foram revisitadas e adaptadas com o objetivo de inserir essa disposição na pesquisa, como elemento central do trabalho educacional".(Cipollone, 1998)

A existência de educadoras com formação superior e em diferentes categorias profissionais é vista como vantajosa, pois contribui para a participação e troca de conhecimentos que podem tornar o trabalho mais eficiente.

O lado positivo é que, como profissional formado, você pode ajudar o outro. Mesmo noutra posição, eu posso te dar uma luz e você pode me dar uma luz. Se os dois estão abertos tem a troca. A gente vê muito na creche, a maioria das pessoas são formadas em pedagogia, então "Olha eu vi uma outra coisa, eu li uma outra coisa", tem uma troca de conhecimento e você ajuda o outro a ver, como o outro com outra formação, ajuda a ver.

Mas destacam que é necessário um investimento pessoal em seu próprio desenvolvimento.

E é difícil essa relação com você mesma e o seu trabalho, você tem que exercitar esse teu lado de estar buscando sempre não ficar no mesmo lugar, mas estar inserido num grupo.

\section{A reflexão sobre o trabalho é necessária para haver mudança}

É um momento de reflexão do trabalho. A gente estava até conversando no [encontro] passado quando nós fomos embora: o quanto a gente está precisando desse momento de reflexão. É difícil, a gente tem que abrir mão de bastante coisa para poder estar aqui no sábado, tanto nós quanto vocês também. Mas se a gente está tão comprometido com a educação, que pelo menos a gente possa se dispor a fazer essa discussão que é reflexiva e é um momento de troca.

Ao reconhecerem como necessária a busca por uma melhor formação profissional, salientam que, para isso, também precisam dispor de recursos financeiros próprios.

$O$ educador também tem que estar comprometido e engajado em estar estudando mais, estar pesquisando mais para estar crescendo junto com a educação, não adianta querer que a educação cresça e você não estar mudando junto. Não basta só gostar, tem que ter investimento financeiro mesmo, porque a universidade não pode bancar, então você tem que ter esse comprometimento, de estar buscando e renovando sempre suas informações. 
Por precisar custear individualmente cursos que são de interesse profissional, muitas vezes não podem realizá-los.

A gente é levada a investigar, a pesquisar, mas ao mesmo tempo, dá um sentimento, do desconhecido, a partir do momento que tem poucas oportunidades. Até pelo não reconhecimento financeiro, [tem] cursos que a gente quer fazer e não consegue custear, e a gente é cobrada por uma coisa que a gente não consegue dar conta. Então a gente acaba enterrando muita coisa que a gente gostaria de estar trazendo mais.

Diante das dificuldades para realizar os cursos, buscam aperfeiçoar-se criando oportunidades e aproveitando os momentos de trabalho.

Ao mesmo tempo, mesmo enterrando muita coisa, a gente também vai cavando, seja em conversas, seja em leituras, buscando mesmo, modos de se trabalhar, meios, trocando idéias, não fica só aquela coisa passiva como assistente. Não, nós vamos prá campo mesmo porque senão a gente não consegue.

Conforme lembra Mello (1999), "A cultura, as concepções, os valores, as expectativas, os conhecimentos prévios fazem parte da identidade do educador. Todos esses aspectos estão presentes no momento em que ele está exercendo seu trabalho". Por isso, a grande questão do trabalho de formação, conforme analisa Dutoit (1995), é construir um papel profissional e um trabalho coletivo partindo da realidade das diferentes formações e concepções dos educadores. A fala a seguir corrobora isso:

Também é um aprendizado para a gente. Eu, por exemplo, recebi essa criação de que meu pai olhava prá mim, era suficiente, não precisava falar nada. Então quanto eu fui buscar isso prá minha formação profissional, a importância de eu estar refletindo sobre o que foi passado prá mim e o que eu ia passar para as crianças.

Essa autora destaca, ainda, a importância do envolvimento do coordenador, "no sentido de estar atento para suas próprias concepções, podendo assim interpretá-las para que possa propiciar situações de grupo, onde os educadores possam re-significar sua função a partir da reflexão" (Dutoit, 1995). 
- O CUIDADO DA CRIANÇA NA CRECHE •

Os subtemas encontrados nesse tema foram o cuidado da criança, o cuidado e o trabalho com as crianças e relações entre cuidar e educar.

Vale esclarecer que, na apresentação dos resultados, mantivemos sob o tema $\mathbf{O}$ cuidado da criança na creche somente as atividades, situações e idéias que foram explicitamente definidas como cuidado. Por isso, pode-se notar que os demais temas também contém situações e questões relacionadas ao cuidado. Por exemplo, é o que ocorre com as atividades relativas à adaptação, à recepção diária da criança, ao atendimento individualizado, à flexibilidade das normas, à promoção da auto-estima, à organização do trabalho, ao acolhimento da família.

\section{PARA AS COORDENADORAS}

\section{- O cuidado da criança}

"Cuidado é tudo que você oferece à criança". Esta frase é bastante significativa, no sentido de explicar grande parte do que foi dito sobre o cuidado pelas coordenadoras. No detalhamento das falas, denota-se que cuidar é atender as necessidades da criança, para promover seu bem-estar físico, bem como provê-la de relações afetivas e sociais. Isto é justificado como parte fundamental da vida da criança.

Cuidar é tudo que você oferece à criança: a relação afetiva, alimentação, a higiene, pensar num projeto de trabalho com essa criança, da brincadeira, da atividade, respeitar o ritmo da criança. A gente não costuma separar muito cuidado da higiene, das brincadeiras, das atividades, quando a gente senta para planejar.

As primeiras menções sobre o cuidado referiram-se a ações dirigidas ao bem-estar infantil, relativas ao conforto físico. Cuidar enquanto realizar ações que tenham como objetivo atender necessidades orgânicas tais como agasalhar, alimentar, cuidar do preparo do alimento, ensinar a comer, hidratar, higienizar, deixar confortável, proporcionar segurança e bem-estar físico, surge em todas as falas.

$\mathrm{O}$ atendimento às necessidades se dá "fazendo", "ensinando" e 
"supervisionando" a criança ou deixando o ambiente confortável e seguro para ela.

Cuidar, é ver se [o tempo] esfriou, você tem que estar ligada nisso, se esfriou você põe uma blusa, se esquentou, você tira, se está adaptada à temperatura, se está se alimentando direito, se está bebendo água, se quando vai ao banheiro lavou a mão, se precisa de ajuda quando é pequenininho, para se limpar, estar ensinando; na hora de dormir, se está gostoso, se o colchão está bom, se o lençol está limpo; a alimentação, a comida, tem todo um cuidado com a comida.

Quando a gente fala no cuidar, vem, realmente, a alimentação, nutrição, saúde...

Eu vejo cuidado como uma parte integrante da vida e do desenvolvimento. Não dá prá ensinar a ler e ao mesmo tempo não ensinar a ter uma higiene pessoal legal, se alimentar bem, cuidar prá que ele não sofra um acidente, ter um olhar diferente prá isso, que é uma coisa importante dentro dessa faixa etária.

O cuidar de uma criança envolve todos os aspectos físicos com relação à saúde, à alimentação, ao bem-estar dela.

Uma coordenadora destaca que essas ações não podem se restringir a atos mecânicos, com um fim estrito em si mesmas, sem relação com 0 processo educativo, tal como era o cuidado antigamente.

Os conceitos estão se transformando. Historicamente, a questão do cuidado era muito isolada em relação àquilo que se entendia como educar. Cuidar era dar comida, dar banho, cuidar da segurança, desconsiderando a relação. Eu podia dar comida e estar pensando em outra coisa, mas estava alimentando, me desincumbindo dessa tarefa, da minha obrigação, enquanto adulto, de dar comida prá esse bebê.

$\mathrm{Na}$ perspectiva da coordenadora, o atendimento às necessidades (biológicas) infantis, o cuidado hoje em dia, assume um caráter de ações estreitamente ligadas ao bem-estar e à educação.

Cuidado, hoje em dia, [é] cada vez mais entendido como função da educação.

Se você chega numa instituição, e vê aquele monte de criança com o nariz escorrendo, você já percebe, ninguém tem o olhar para a questão da saúde e do bem estar, porque a criança comendo secreção nasal é complicado, não é? Um espaço em que elas nunca possam sair, fechadas. Você já percebe que este cuidar está deixando a desejar, no trabalho educacional, que tem tudo a ver.

Para além de atender necessidades físicas, o cuidado na concepção atual seria toda intervenção ou ações que 0 adulto dirige à criança para 0 atendimento de suas necessidades, mas com a preocupação de transmitir 
conhecimentos, zelar pelo bem-estar e pela relação interpessoal.

É uma mudança de concepção pensar na questão do cuidado como um ato que um adulto dirige a uma criança, com a idéia de transmitir um conhecimento e de zelar por um bem-estar ou por um estado de uma certa relação com a criança. No fato de uma pessoa cuidar de uma criança, está implicada a idéia de que ela esteja tomando essa criança como um sujeito de uma certa época, que depende dela para uma série de coisas, não só para entender aquilo que se dá no mundo, mas para se sentir bem, para estar bem cuidada, alimentada, satisfeita, escutada, respeitada, naquilo que ela tem para dizer, naquilo que ela tem para pedir de um adulto em termos de cuidado.

Estas definições falam sobre uma nova forma de fazer o cuidado, que integra a pessoa da criança. Isto significa: a higiene, a alimentação, as ações para garantir a segurança precisam continuar sendo realizadas, mas não podem caber mais, nessas ações, procedimentos mecânicos, como se estivessem sendo realizados na criança; ao invés disso, as ações devem ser realizadas com a criança, o que demanda um relacionamento e resulta em aprendizagem para ela.

Nessa linha de raciocínio, cuidar é proporcionar atenção e liberdade. Atenção é olhar para, ouvir, conversar, colocando-se na altura da criança. Liberdade é permitir que a criança desfrute o espaço da creche. Tal como na fala anterior, a atenção denota respeito pela criança.

Os educadores abaixando, conversando com as crianças, dando liberdade para que eles possam desfrutar o espaço da creche da melhor forma possivel.

Nos relatos de situações de bom cuidado ou de cuidado insatisfatório prestado a uma criança, identificam-se as ações de dar colo, atenção, liberdade, cuidado médico, atender a família, como ações de cuidado integral ou de atendimento global da criança, no contexto da creche. A abrangência do cuidado vai se ampliando pouco a pouco nos discursos.

O que representa que ela não foi bem cuidada é deixar chorar, não pegar no colo, acho que é muito colo mesmo, eu não sou dessa linha "tem que deixar chorar porque senão acostuma". É não dar atenção para a criança mesmo, quando ela está falando, quando ela está balbuciando você não estar ligada.

Além de cuidarem, colocarem no colo, conversarem e ao mesmo tempo dar liberdade para que ela pudesse ir crescendo, se fez todo um cuidado médico mesmo, ela foi para investigação no HU. Foi um cuidado super 
integral dessa criança, tinha um educador com ela, eu conversava com a tia, que é a pessoa que estava substituindo a guarda, a família.

Vale destacar as referências ao colo como ação de cuidado. É freqüente encontrarmos a idéia de que dar colo "acostuma mal" a criança. Os pais jovens, muitas vezes, são advertidos por outros membros da família para que evitem manter a criança ao colo. Mas, felizmente para as crianças, cada vez mais essa concepção vem sendo contestada e vem se comprovando a importância do toque até mesmo para a formação da identidade da criança. Por essa razão, Maranhão (1999) adverte que "o colo confortável e seguro é um cuidado fundamental e deve fazer parte do trabalho educativo sempre que necessário"; e mais: "crianças de diferentes idades precisam sentir-se fisicamente acolhidas pelo outro" seja em situações de dificuldade, seja em momentos de alegria.

A creche cuida quando respeita o ritmo das crianças.

A vida de São Paulo é muito corrida, e acaba deixando as pessoas estressadas desde pequenas. E falta um pouco essa coisa mais calma, mais tranqüila, de respeitar mais o ritmo.

Também é cuidar bem acolher a criança apesar das diferenças que ela possa ter em relação a um padrão infantil idealizado.

É uma criança que, apesar de não ser o ideal de criança que um professor possa ter, que não é uma criança que você olha e diz "saudável", ela tem espaço na creche, as pessoas não lidam com ela como se ela fosse uma criança que tem menos, as crianças não lidam com ela como uma criança diferente, eles percebem a diferença dela, mas tem um acolhimento. Tem uma diferença mas tem uma possibilidade de aproximação. Com ela, as educadoras puderam lidar com a sua expectativa de uma criança normal, com desenvolvimento padrão, que essa criança não apresenta.

Além das ações diretas à criança, o cuidado contempla também a organização do ambiente, de forma a permitir que a criança brinque, tenha oportunidades de desenvolver seu potencial, sendo sempre respeitada em seu ritmo individual.

É organizar bem o espaço para receber as crianças, um espaço gostoso, onde a criança possa brincar, onde os brinquedos estejam ao seu alcance; ela ter várias oportunidades de estar desenvolvendo o seu potencial.

A maioria das coordenadoras expressa que cuidar demanda criação de vínculo, isto é, estabelecer uma relação afetiva, uma ligação entre a educadora e a criança. Questões relacionadas à importância dessa ligação foram que ela 
promove o desenvolvimento da criança, como uma resposta ao adulto, e que o adulto precisa saber diferenciar esse vínculo da relação de paternidade. Ações de aconchegar e confortar foram comportamentos relacionados à ligação afetiva.

Cuidar é ter uma relação, um laço afetivo muito forte com a criança.

Não dá para cuidar, sem se vincular, sem se apegar, sem querer coisas da criança, como se ela fosse sua, mesmo sem ser. É preciso querer coisas da criança para que ela se desenvolva, como se ela fosse algo importante para você e ela de fato é.

As coordenadoras revelam uma representação de que, para que 0 cuidado ocorra bem, a formação de vínculo afetivo é quase indispensável. A esse respeito, o Referencial (Ministério, 1998) traz a idéia de que o vínculo é necessário e conseqüência de algo anterior - compromisso, solidariedade e confiança.

"Para cuidar, é preciso antes de tudo estar comprometido com o outro, com sua singularidade, ser solidário com suas necessidades, confiando em suas capacidades. Disso depende a construção de um vínculo entre quem cuida e quem é cuidado".

Este é um ponto para uma discussão importante. É evidente que, quando a criança começa a freqüentar a creche, não é possível já haver vínculo, mas isso não significa que ela seja mal cuidada. Conforme descrito no tema $\mathbf{A}$ creche, a criança já é bem cuidada antes entrar na creche, no período da entrevista e de todas as atividades realizadas para preparar sua adaptação. Isso mostra que o adulto não depende do vínculo para cuidar bem, mas que ele está "pré-disposto" a cuidar e, de fato, o faz. Assim, o poder explicativo do vínculo para a instituição do cuidado é nulo nessa fase. Algumas hipóteses a respeito dos fundamentos do cuidado nesse período são: a internalização de atitude de respeito à criança e respeito à família, conhecimento das necessidades da criança (antítese do senso comum), e senso de dever.

Outra discussão, conseqüente a esse ponto de vista é: em que medida a idéia da necessidade de estabelecimento de vínculo não está sendo um obstáculo para pensar o cuidado? Isso porque pode deixar implícito que basta gostar das crianças para cuidar bem delas ou, por outro lado, que se não tivermos esse afeto por todas as crianças não estaremos cuidando bem. Ou, ainda, que é possível que as educadoras se vinculem a todas as crianças e 
vice-e-versa, o que, provavelmente não condiz com a realidade. Dessa forma, a afetividade aparece, nesse discurso, semelhante ao senso comum, sem uma reflexão maior acerca de características profissionais de afetividade.

A questão da afetividade aparece com conotações distintas a essa primeira descrição. É quando o cuidado físico acontece num contexto de relações pessoais, de interação entre o adulto e a criança, na qual o adulto precisa estar atento à criança.

Cuidado, eu entendo como o atendimento às necessidades da criança, físicas, afetivas, emocionais, de relação, que é aquilo que ela precisa prá viver e prá viver bem, do que ela depende em relação ao adulto. Então, a gente precisa ter atenção no sentido de estar provendo, cuidando dessas necessidades.

Estar atento tem como sinônimos ser atencioso, ser cuidadoso (Ferreira, 1999), ou seja, trata de atitude e não de ações. É o alicerce para realizar a primeira etapa do cuidado segundo Mayeroff (1971): "o conhecimento - o cuidador deve ser capaz de entender as necessidades do outro e de responder a elas de forma adequada". Deste modo, para atender as necessidades, é preciso, antes, reconhecê-las e saber como atendê-las. Uma vez que a coordenadora afirma que o cuidado é o atendimento das necessidades, não fica claro se ela compreende a atenção como um ingrediente do cuidado.

$E$ é isso o que dizem essas outras coordenadoras: a afetividade relaciona-se a ter sensibilidade para perceber o que a criança precisa.

A J. se machucou, ficou toda ralada e eu vi e saí correndo para ajudar. Isso, geralmente, a gente faz com todos. Quando é um grito maior, uma dor maior, todo mundo sai. E a (auxiliar de enfermagem) não estava na sala, eu disse prá ela: J. eu vou te ajudar. Eu vou ficar bem pertinho de você, tá? A dor pode não diminuir, mas talvez sabendo que nós estamos aqui com você... E ela foi parando, parando e a gente ia percebendo que era maior que a dor do machucado. À tarde, ela passou e não falou absolutamente nada. Ela só chegou e entrou, coisa que ela não faz na minha sala, me deu um beijo e saiu. A criança não fala, não verbaliza, que está precisando de alguém, mas você tem que ter sensibilidade para perceber.

A principal coisa é estar atenta, é ter sensibilidade para perceber o que a criança está sentindo, o que ela está pedindo, isso seria o bom cuidado.

Já foi dito que a sensibilidade para entender a necessidade e o desejo individual, e de responder a eles de forma adequada, segundo Mayeroff (1971), 
é o conhecimento. $\mathrm{O}$ autor enfatiza que boas intenções não são suficientes para garantir uma resposta de cuidado.

Um conhecimento aprimorado sobre o processo de desenvolvimento infantil é o primeiro ponto a ser considerado. Sigaud e Veríssimo (1996) apontam que "a maioria das crianças apresenta características físicas e fisiológicas, comportamentos e habilidades semelhantes quando numa mesma faixa etária (...) com variações individuais decorrentes das diferenças hereditárias e ambientais de cada uma". Assim, o conhecimento sobre crescimento e desenvolvimento infantil permite ao profissional "compreender a criança, sabendo o que esperar dela em cada faixa etária, bem como planejar, prestar e avaliar o cuidado, considerando suas necessidades relativas ao desenvolvimento" (Sigaud e Veríssimo, 1996). É possível observar, por exemplo, que a equipe organiza o período de adaptação, em parte, tendo por base o conhecimento das características e necessidades da criança.

É preciso também compreender as características particulares da cultura na qual as crianças estão inseridas. Mussen, Conger e Kagan (1977) explicam que 'toda cultura tem sua própria personalidade 'típica' - um dado padrão de motivos, objetivos, ideais e valores - que são característicos e valorizados por essa cultura e adquiridos pela maior parte das crianças que crescem nela". Isso implica a necessidade de contato aprofundado com a família, o que, além de permitir o conhecimento dos valores, saberes, atitudes educativas, também possibilita o conhecimento das expectativas, medos, necessidades dela em relação à creche.

Esse conhecimento ajuda a pessoa que cuida a ser empática com a criança, isto é, ser capaz de compreender as situações tal como a criança as compreende. Assim, o conceito empatia define o que é "ter sensibilidade para perceber o que a criança precisa".

Para Mayeroff (1971), cuidar é ajudar o outro a crescer e a se realizar, num processo de desenvolvimento, em que o outro ser humano é respeitado como ser independente, assim como são respeitadas suas necessidades, cujo atendimento é compromisso do cuidador.

O seguinte trecho da entrevista registra que o vínculo e a semelhança 
nas ações aproxima o papel da educadora ao do pai/mãe, ainda que não os substitua nem vise construir uma relação que satisfaça desejos pessoais de maternidade ou paternidade.

Cuidar de uma criança de uma outra família, se vincular a ela, [é] um cuidado muito próximo ao que seria de uma mãe ou de um pai, sem essa criança estar satisfazendo necessidades suas de uma criança como filho.

A idéia expressa acima conduz à interpretação que, quando o adulto que cuida sente-se como um genitor isso pode não ser adequado. Segundo a Teoria Psicossocial do Desenvolvimento Humano de Erikson, há uma fase do desenvolvimento (saudável) em que o ser humano pode viver sentimentos de paternidade/maternidade em relação às gerações mais novas. Talvez, se esse conhecimento fosse debatido, poder-se-ia concluir que sentir-se pai ou mãe ou "sentir-se amando as gerações seguintes mesmo não estando ligado a elas por traços biológicos" é sinal de que o processo de desenvolvimento está seguindo seu curso.

Nesse outro trecho, a idéia de vínculo aparece com uma conotação um pouco diferente, no sentido de indicar, de uma forma realista, que o vínculo é diferenciado para cada criança e que ele traz um impacto não só para a criança mas também para o profissional que trabalha com ela.

A gente vai criando vínculos com a criança que não é um vínculo de pai, de parente, de mãe, mas é um vínculo tão especial. Ele é importante, é personalizado, é diferenciado para cada criança. É muito interessante porque ele não é completamente profissional, no sentido desse profissionalismo que eu sou até aqui, até esse horário, e não mais que isso. É um vínculo humano mesmo. A gente cria uma história com cada criança que sai daqui.

A importância de destacar que o vínculo é diferenciado é reforçar que o cuidado não pode ser formatado por esse vínculo mas sim por um direito da criança e uma competência profissional que deve independer da educadora gostar mais ou menos da criança.

É interessante notar que o vínculo afetivo não é visto como algo profissional, denotando uma representação de que afeto e trabalho não se misturam.

Cuidar compreendido como sendo do âmbito da qualidade das relações humanas, passa a ser uma atitude - de atenção individualizada, respeito às 
dificuldades, ajuda - para com a criança, presente em todos os momentos de interação, inclusive no processo educativo formal. $O$ cuidado integrado ao momento pedagógico, tem o sentido de estar atento a como a criança está vivendo a experiência de aprendizagem.

Não adianta eu pensar num projeto que tem um olhar para o ensino $e$ aprendizagem e eu quero desafiar o grupo, se eu tenho uma criança sofrendo porque não está conseguindo. Eu deixo de olhar para ela. Então, cuidar também tem a ver com as relações.

O primeiro passo para o estabelecimento de uma boa interação com a criança é favorecer sua adaptação na creche. A criança precisa sentir-se acolhida desde sua entrada e desligar-se da mãe sem trauma. Para isso, 0 processo de adaptação é planejado, acompanhado, avaliado, tudo com muito cuidado:

Para essa faixa etária [6-7 meses] é a adaptação, você tem que tomar cuidado, e esse desligamento da mãe ir embora, fazer realmente aos poucos.

O período de adaptação é um momento muito especial, de receber bem.

O jeito principalmente de receber a criança quando ela chega as primeiras vezes na creche, tem que ser muito acolhedor, muito cuidado, o esmero tem que ser grande.

A adaptação foi lembrada particularmente como o momento da entrada, da inserção da criança na creche. Conforme Mello (1999), a adaptação é considerada o processo de familiarização da criança, de sua família e do educador a uma dada situação nova, seja a época de seu ingresso, durante as mudanças de turma ou educador e quando a criança sai da creche.

A fase de adaptação é difícil pois é um período que causa ansiedade e mobilizações na creche, como modificações do espaço físico e da rotina. Para os pais, não é fácil deixar seus filhos com outras pessoas que ainda não conhecem. Mas, geralmente, as crianças são as que sofrem o maior impacto, devido a suas capacidades e recursos restritos para lidar com situações novas.

Por isso, para ajudar efetivamente as crianças na adaptação, é necessário compreender as características do processo de desenvolvimento infantil que interferem com essa experiência.

Como primeira questão, temos a idade da criança quando da entrada na creche. Teoricamente, as crianças poderiam entrar a partir dos 4 meses 
(exceto na creche Saúde, que não tem berçário). Mas essa é uma situação praticamente inexistente pois não há possibilidade de inscrever a criança antes dessa idade e o período de inscrição e seleção é restrito e fixo, em dezembro Além disso, da seleção até a entrada da criança, pode decorrer alguns meses, uma vez que janeiro é mês de férias coletivas e, depois, há um escalonamento para que a entrada das crianças novas seja gradativa.

Assim, geralmente as crianças encontram-se no segundo semestre de vida quando começam a freqüentar a creche. Esse é um período conturbado, uma vez que é nessa época que os bebês desenvolvem a ansiedade diante de estranhos. O estranhamento é uma resposta de ansiedade a um rosto humano desconhecido, que pode ser encontrado por volta dos 6 meses de idade, atingindo 0 máximo em termos de frequência por volta dos 8 meses e desaparecendo gradualmente entre os 12 e os 15 meses (Mussen, Conger e Kagan, 1977). Relaciona-se à capacidade de percepção de uma discrepância entre esquemas mentais estabelecidos para objetos conhecidos e a falta de esquemas para o objeto novo. Assim, além de todas as ações realizadas pela equipe da creche na entrada da criança, e que são notórias, uma forma de tornar a adaptação menos crítica seria antecipar seu ingresso para antes desse período de estranhamento. Isso implicaria em mudar o período de entrada da criança e em ter vários momentos de entrada durante o ano, especialmente para as crianças menores de um ano.

O cuidado é explicado também como a maneira como o adulto realiza cada contato com a criança durante as atividades de higiene, alimentação e outras. Atender a criança com cuidado é garantir que cada ação junto à criança esteja imbuída de afetividade, de brincadeira, de interação, de comunicação.

É a forma como acontece, porque você pode ter uma criança super bem alimentada e mal cuidada. A gente se preocupa muito, na conversa com os educadores, com a maneira como a alimentação vai ser feita, o momento do banho que é super legal, são momentos que ajudam a formação da criança. Não adianta só botar na banheira, lavar, limpinho, não tem piolho. O banho é muito legal, tem que ser bem dado, mas associado a um olhar, a um brincar do adulto com a criança, a um toque no corpo da criança porque também é assim que a criança vai se sentindo gente e vai dando vida às partes do corpo dela. É com o toque do adulto, a cosquinha

\footnotetext{
${ }^{1}$ In: Universidade de São Paulo. Coordenadoria de assistência social. Divisão de creches. Apresentando a creche central. São Paulo, 1999.
} 
que a gente faz, a graça, é esse lado humano que está presente na relação. A criança bem cuidada é a que recebe o que precisa de uma maneira humana, com um olhar afetivo, isso está presente para quem trabalha com educação infantil.

Uma das coordenadoras concebe o cuidado como um compromisso e generosidade que coloca a necessidade da criança em primeiro lugar.

$E$, principalmente na educação infantil, o educador tem que poder ser generoso. Se ele está tomando café e uma criança cai e grita "eu quero a fulana", ela tem que parar. Não é porque ela tem os quinze minutos "Ah, é o meu direito". É direito sim, mas é maior que o direito. Quando você pensa na generosidade, você não tem que pensar em direitos e deveres. Você tem que poder acolher, acudir, ficar perto e eu percebo que isso é raro [entre as educadoras].

O compromisso e a generosidade são componentes do Modelo humanístico de cuidado, descrito por Fry (1990), particularmente conforme enunciado por Jean Watson. Se os comportamentos esperados em decorrência dessa atitude de compromisso não são observados, evidencia-se que a concepção das educadoras sobre o cuidado é diferente dessa.

Ao falar sobre o significado de cuidar da criança de outra pessoa, as coordenadoras destacam que cuidar é assumir responsabilidade pela criança, particularmente para elas, porque delegam a outros 0 atendimento das crianças. A responsabilidade é relativa a todas as dimensões: é preciso cuidar bem para que a criança desenvolva-se em todas as áreas.

Envolve uma grande responsabilidade, que é a questão da segurança, da confiança. É muito grande, você estar responsável por crianças que, muitas vezes, não sabem falar o que acontece com elas. Precisa dar conta de criar essa relação de confiança [com a criança] e de confiar na equipe com quem a gente trabalha.

É a questão da responsabilidade de trabalhar com crianças. Se eu falo que a primeira infância é fundamental na formação da pessoa, eu tenho que fazer o melhor. E eu não sei que conseqüências pode ter na constituição da criança, porque são coisas que não são visiveis. Se a criança quebrou a perna, a gente tem uma responsabilidade grande mas a gente sabe que quebrou a perna. Na formação da personalidade, eu não sei exatamente se teve alguma coisa que não foi legal, que tem alguma seqüela, algum efeito não positivo.

O cuidado é caracterizado pelas coordenadoras como bom ou ruim em função das conseqüências que gera para a criança. Cuidar só das 
necessidades físicas é insuficiente, porque a criança precisa estabelecer relações, interações, para tornar-se um ser de relações, humana.

O cuidar está muito ligado à formação do indivíduo, e a formação se dá na primeira infância. E a personalidade só pode se constituir com um cuidado adequado. A criança mal cuidada é uma criança que não pode ter o mínimo de confiança no adulto, se ela tem fome que ela vai ser alimentada. Cuidar no sentido físico de dar uma mamadeira, trocar uma fralda e alimentar razoavelmente bem, [não é um bom cuidado se a criança] não tiver vínculo com um adulto, um vinculo suficientemente forte, bom, que possa ajudar a constituição dessa criança. Porque é olhando no outro, aprendendo com o outro, que a criança vai confiando no outro. É esse olhar que o adulto tem para a criança, esse olhar que acredita que a criança vai crescer que a faz crescer e se formar. Uma criança bem cuidada é uma criança com pessoas envolvidas na educação dela, conscientes e pensando que o cuidado não é só dar coisa material, não é só alimentar, vestir, trocar, senão a gente poderia fazer uma fábrica, uma creche fábrica, de trocar e por criança quentinha.

O cuidado ao se relacionar com a criança nas atividades pedagógicas é o compromisso de tornar o processo de aprendizagem infantil prazeroso, estimulante, garantindo não apenas uma transmissão de conteúdo mas que a criança sinta-se bem.

Não sei se a gente aprende em algum lugar, é uma coisa de um compromisso maior, principalmente no trabalho com crianças, e as pessoas não têm a dimensão disso hoje. [Dizem:] "Eu quero ser professora". Só que ela não tem dimensão das seqüelas que ela pode deixar nas crianças, uma vergonha de ler, de se expressar, medo de se colocar e outras coisas mais que a gente sabe. Eu estou falando mais do aspecto emocional, afora a questão do conteúdo também, de como fazer isso. Criança que não tem prazer. Escolas que têm livros, mas a professora não lê, não deixa a criança desfrutar disso. Não que a escola tenha que compensar, mas ela tem que ter o papel dela sim, isso a gente tem que aprender.

O cuidado na instituição não substitui o cuidado da família e é diferente porque é permeado por regras.

Quando o cuidado está posto num ambiente organizado, um ambiente institucional, não há nunca uma substituição. É outro tipo de cuidado, permeado por outras coisas, onde entre você e a criança tem uma instituição sempre, de regras, de maneiras de se relacionar, com particularidades de cada grupamento que se forma, tem sempre um intermediário.

A representação de que o cuidado na família não tem regras não condiz com a realidade. Cada família tem suas regras que podem estar mais ou menos próximas às da creche. 
Evidencia-se também que o cuidado institucional é diferente do familiar nas manifestações das educadoras. Aquelas que são mães, falam sobre a diversidade do cuidado que oferecem ao filho e às crianças na creche e a coordenadora reconhece isto como natural, pois são relações diferentes a de mãe-filho e a de educadora-criança.

Algumas educadoras que são mães e que têm filhos na creche, dizem como é contraditório para elas não conseguir fazer nada disso em casa. Como se elas tivessem que fazer, entende? Tem uma diferença muito grande, entre ser um educador de uma criança e ser mãe e pai dele, por isso que não é uma substituição.

Ao falar sobre cuidado à criança com necessidades especiais, a coordenadora enumera uma série de ações que, de alguma forma também foram apontadas como cuidados para todas as crianças: estabelecer relação favorável ao aprendizado, adequando as expectativas às possibilidades concretas da criança; ajudar a criança a se desenvolver, a se instrumentalizar dentro de seus limites ainda que ela não seja capaz de um aprendizado "normal"; ajudá-la a estabelecer parcerias no grupo de crianças; lidar positivamente com comportamentos indesejados; segurar no colo, ficar junto; problematizar com a família as necessidades da criança. Cada vez mais vai se delineando uma concepção de cuidado como algo bastante amplo, relacionado principalmente a ações que visam garantir apoio, favorecer que a criança possa adquirir o máximo de competências no seu processo de desenvolvimento.

E, finalmente, cuidar também é atender as necessidade da mãe e da família, nos processos relacionados à experiência da criança na creche.

Como as crianças choram muito, as famílias também [sofrem]. A gente tem que cuidar dos dois, da criança e da família. Teve um ano que a gente montou um trabalho: a gente filmou as entrevistas com as famílias, depois a entrada logo no início, depois uma a duas semanas, que a criança ainda precisava muito, não conseguia dormir, não conseguia relaxar, aí sem a família, como que a criança respondia, e um mês depois, como que ela estava bem, já entrando na rotina, já era tranqüilo para ela entrar na sala de sono, dormir, comer. Foi super legal. A gente mostrou esse vídeo para os pais e eles: "é verdade, precisa desse tempo mesmo".

Em algumas falas, destaca-se que o cuidado não se refere somente a atividades relativas à saúde, higiene, alimentação, mas os primeiros exemplos 
são sempre esses. Uma coordenadora aponta essa contradição: ao mesmo tempo em que conceitua o cuidado mais amplamente, ressalta que os exemplos que surgem à mente mais prontamente referem-se a essas atividades. Na continuidade das entrevistas, as ações de cuidado vão se tornando cada vez mais amplas. Por exemplo, explicando a necessidade de também cuidar dos pais durante o período de adaptação da criança, a coordenadora relata um trabalho realizado que visa orientar, esclarecer e apoiar os pais durante esse período.

\section{Cuidado não satisfatório}

Os exemplos de cuidado não satisfatório referiram-se, em geral, a realidades de outras creches ou serviços de atendimento à criança, bem como a situações hipotéticas.

Hoje, preconiza-se que as propostas de atendimento das creches e préescolas devem contemplar o desenvolvimento da autonomia infantil. Para tanto, a coordenadora postula que cuidar bem é não fazer a criança prisioneira da rotina, é não querer submetê-la a uma proposta que desrespeita suas necessidades e características. Entretanto, a situação que se encontra mais freqüentemente é a ausência de ações que possibilitem a concretização dessa proposta.

Em qualquer lugar que você chega hoje, os profissionais falam "a gente quer desenvolver a autonomia plena". Mas se você fizer uma análise da rotina, já vai perceber que não dá para desenvolver a autonomia de jeito nenhum, que as crianças estão mais prisioneiras da rotina do que outra coisa. Um exemplo fundamental, é a questão do sono numa instituição de período integral. As crianças são obrigadas a dormir, mesmo não estando com sono, e muito menos cansados, mas em nome de que elas acordam muito cedo. Então, elas precisam descansar. Como na escola, na nossa época, em que você não podia ir ao banheiro. Então, a criança acabava fazendo. A gente fala na nossa época para não ficar tão feio, mas a gente sabe que ainda tem isso. O educador controla a questão fisiológica do outro! "Você tem que dormir! Agora não é hora de você ir ao banheiro".

A coordenadora afirma que a visão assistencialista, que predominou durante muitos anos como principal função das creches, ainda retrata a realidade existente em muitas instituições em nosso meio, e, possivelmente, está presente também em trabalhadores das creches deste estudo.

A idéia de chamar de cuidado o que se dá na creche, para algumas pessoas, 
só se transformou o termo assistência para cuidado. Não necessariamente, quando eu escuto as pessoas falando com o educador, se entende o cuidado do ponto de vista mais amplo do que a assistência. É só uma palavra mais correta, do ponto de vista político, atual, mas não necessariamente que a concepção tenha se transformado. Eu já escutei pessoas falando no cuidar e elas definem como assistência mais educação, assistência mais pedagógico, o que eu não acho que é.

A visão assistencial é quando o cuidado é visto como uma etapa preliminar, necessária ao preparo da criança para a situação de aprendizagem em sala de aula, esta sim a função primordial da creche. Nessa visão, o cuidado torna-se algo separado da educação e secundário enquanto função da creche.

Trocar uma fralda, que é a coisa que mais se coloca do ponto de vista da assistência, então limpar a criança, deixar ela limpinha, pode ser um ato simplesmente mecânico de um educador se ele toma do ponto de vista que essa criança tem que estar pronta, e estar pronta é estar limpa, bem alimentada, para receber educação formal, para receber um conhecimento formal. Isso mostra uma separação entre as coisas.

A coordenadora explica sua concepção de que cuidar é não cercear o movimento nem a escolha da criança reportando-se ao que ocorre em algumas instituições de educação infantil do município de São Paulo.

Nós temos uma educadora trabalhando numa EME $\mathrm{P}^{\mathrm{Z}}$ e aí vai me dando um arrepio quando ela fala que a criança tem que assistir televisão, sentada, com perna de índio e com a mão no joelho. Então, você pensa numa criança de quatro anos nessa situação aproximadamente uma hora.

O movimento é uma fonte de impressões agradáveis e produz sensações nos aparelhos muscular e articular que suscitam excitação comparável à expressão da alegria (Wallon, 1995). O Referencial (Ministério, 1998), tendo por base os trabalhos desse autor, diz:

"O movimento para a criança pequena significa muito mais do que mexer partes do corpo ou deslocar-se no espaço. A criança se expressa e se comunica por meio dos gestos e das mímicas faciais e interage utilizando fortemente 0 apoio do corpo. A dimensão corporal integra-se ao conjunto da atividade da criança".

A imobilidade, na situação relatada, não se reduz à postura corporal, o que já seria suficientemente incongruente, uma restrição incompatível com as características e necessidades de desenvolvimento infantis, mas também retrata o que se espera em termos de obediência, pois se trata de uma

\footnotetext{
${ }^{2}$ EMEI - Escola Municipal de Educação Infantil.
} 
imposição à criança, não the sendo permitido ter outra opção. É a tudo isso que a coordenadora se refere. Neste sentido, é um modo de cuidar centrado na disciplina, na contenção, e talvez, até embasado em premissas que denigrem a imagem da criança.

\section{- O cuidado e o trabalho com as crianças .}

Ao abordarem as questões relacionadas ao cuidado, as coordenadoras explicam que este se insere no trabalho porque há uma demanda da criança por cuidado que não pode ser negligenciada. Ao mesmo tempo, destacam que há uma lacuna na formação dos profissionais em relação a essa competência. E percebem que a falta de formação para o cuidado torna-o desvalorizado aos olhos das educadoras.

Assim, o primeiro aspecto considerado é que a criança precisa ser cuidada. O fato de existir uma demanda por cuidado, isto é, de a criança carecer do atendimento a suas necessidades e de não ser ainda capaz de satisfazer por si própria suas demandas, implica a existência de um provedor, alguém que se responsabilize por oferecer essa atenção.

Cuidar precisa.

A relação do adulto com uma criança implica a necessidade que a criança tem do adulto, porque ela não é capaz de fazer algo sozinha. $O$ adulto precisa estar ali, para que ela esteja bem, limpa, satisfeita e tenha suas curiosidades, pelo menos, ouvidas, para que ele possa responder. $O$ cuidado teria que englobar essa visão de necessidade, de algo quase inerente à relação do adulto com a criança.

Antigamente a gente não conseguia pensar nem na questão do sono, mas a gente vem observando o quanto isso é fundamental para o bem-estar da criança na creche.

Nesse sentido, depreende-se que 0 atendimento da criança na creche demanda o oferecimento de uma série de ações que não constituem atividades pedagógicas mas que são essenciais à criança.

Assim sendo, para que o trabalho na creche se realize, é preciso contar com profissionais capacitadas com conhecimentos e habilidades específicos tais como a capacidade de observar, interpretar e compreender os comportamentos e necessidades infantis. Estas competências compõem o cuidar e permitem responder às peculiaridades da criança, não só porque são 
crianças pequenas, como também porque, em sua maioria, permanecem em período integral na creche.

Com a criança pequenininha, a gente tem que ser um excelente observador. Como ela não fala, tem que entender, interpretar, a gente é o modelo, é o falante, é o andante. Não é fácil. Precisa de uma excelente formação.

Na pedagogia e no magistério, o enfoque maior é em relação às crianças de meio período mas, na instituição de período integral, tem que olhar para cada detalhe, a importância do cuidar...

Entretanto, todas as coordenadoras destacam que os cursos que formam os profissionais da área de educação não os preparam adequadamente para esse trabalho, especialmente no que se refere às crianças menores de 3 anos. Durante os cursos de magistério e pedagogia, pouco se investe na capacitação para a educação da criança pequena e para o cuidado. Esse conhecimento é adquirido, então, no próprio contato com o trabalho na creche, em geral de forma assistemática.

Hoje, a graduação [da faculdade de educação da USP] tem a educação infantil, mas é muito pouco. De 0 a 3 anos, a gente não tem um olhar mais aprofundado. $O$ curso de especialização que eu fiz aqui na educação não tem um olhar de 0 a 3 anos, de uma forma mais aprofundada, de estar fazendo uma reflexão do que é a adaptação para crianças bem pequenas, o que é o dormir numa instituição de período integral, como é a alimentação, qual é a relação da fono com a equipe da educação, não tem esses aspectos e a gente vem aprender na creche.

Considerando que a escolarização exigida para os profissionais que trabalham diretamente com as crianças nas creches da USP, até a época da coleta de dados, era o ensino médio mas não obrigatoriamente o magistério, pode-se inferir que o preparo acadêmico das educadoras não contemplava esses conhecimentos.

A respeito da qualidade da formação dos professores, Barreto (1994) expõe que:

"no caso da educação infantil, que abrange 0 atendimento às crianças de 0 a 6 anos em creches e pré-escolas, exigindo que o profissional cumpra as funções de educar e cuidar, o desafio da qualidade se apresenta com uma dimensão maior, pois é sabido que os mecanismos atuais de formação não contemplam essa dupla função".

Não tendo uma ênfase no processo de educação formal, as educadoras reproduzem aquilo que aprenderam desde sua infância, resultando em uma visão leiga, de senso comum sobre o cuidar. Quando isso ocorre, há um risco 
de que o cuidado seja visto como uma etapa a ser realizada para que a criança possa então estar pronta para o aprendizado, consagrando uma cisão entre cuidar e educar e reforçando a menor importância do cuidar. $\mathrm{O}$ trabalho com crianças pequenas é sentido como sendo de menor valor em termos do que seja o trabalho profissional do educador.

Tinha um certo preconceito, quando eu cheguei aqui, há quatro anos atrás: o educador do berçário se sentia babá, desvalorizado. As educadoras do módulo 2 às vezes falavam para as crianças "sai daí do berçário, está com cheiro de cocô", e os educadores do berçário se sentiam ofendidos e diminuídos, no sentido de que "a gente trabalha aqui só trocando cocô e xixi e isso não é trabalho de educador".

[Para muitas pessoas, o cuidado é] uma prévia, uma assistência, para que a criança se torne um aluno, se transforme num aluno, na medida em que está limpo, cuidado, alimentado, então está pronto para ser um aluno do professor.

Na formação na vida da gente, quem trabalha com crianças pequenas vai cuidar, e o trabalho do professor, do educador, na sala de aula, é a partir dos 3 anos, quando não se tem fralda, as crianças estão mais independentes. O magistério, os cursos de pedagogia, não têm um trabalho nesse sentido, têm uma separação clara.

Essa concepção é evidente em muitos outros serviços de creche, nos quais há uma divisão entre as atividades: auxiliares das professoras realizam as ações de higiene, alimentação, repouso, enquanto as professoras somente realizam atividades de sala de aula, pedagógicas. Isso não ocorre nas creches da USP, pois todas as atividades realizadas com as crianças são de responsabilidade direta das educadoras.

Em algumas instituições, a gente vê que quem cumpre a função de limpar, são as auxiliares, são as assistentes do professor, o professor não está envolvido, não tem um contato com o corpo da criança.

Em suma, no discurso das coordenadoras, depreende-se que a inserção do cuidado no trabalho com a criança tende a caracterizar-se como uma tarefa para a qual as educadoras nem sempre vêem sentido em que seja realizada por elas, pois é concebida como um pólo oposto à educação, particularmente quando ingressam no serviço.

Eu sinto que tem uma certa frustração, principalmente os educadores que estão entrando agora.

Assim, as coordenadoras são unânimes em afirmar que o trabalho junto às crianças pequenas, que constitui primordialmente atividades de cuidado, só 
é valorizado pelas educadoras graças ao investimento efetivado na formação em serviço.

Apesar de a falta de preparo e de valorização para o cuidado terem sido atribuídas a deficiências dos cursos, pode-se aventar que a maior dificuldade é que vivemos numa cultura que não valoriza o cuidado. Por isso, mesmo com todo o trabalho das equipes técnicas para valorizar o cuidado, é difícil transformar a visão das educadoras de forma radical.

\section{- Relações entre cuidar e educar •}

As coordenadoras exploram a relação entre cuidar e educar, de acordo com suas conviç̧ões acerca da função da creche, destacando-se como a relação mais citada entre essas duas funções a preocupação de ensinar algo durante as atividades de higiene e alimentação. Isto é, ao prestar um cuidado físico, de higiene, alimentação, enfatizar aspectos educativos, tais como aprender sobre as partes do corpo ou como se comportar à mesa.

Ao explicarem o cuidado e falar de sua dificuldade em separá-lo da educação, expressam uma inter-relação íntima e indissociável entre ambos, seja o cuidado englobado na educação, seja a educação dentro do cuidado

A creche tem essas duas funções básicas do cuidar e do educar. O cuidar acaba sendo a linha de trabalho, as diretrizes mesmo. Dentro do cuidar tem milhões de aspectos que devem ser olhados enquanto aspectos educativos. As questões da alimentação, da higiene, dos hábitos, alimentares e sociais, da comunicação, da forma de lidar com as pessoas, das relações, tudo isso está ligado ao trabalho dos conteúdos. São dois eixos, mas são dois eixos completamente interligados.

Cuidar de uma forma que é cada vez mais, na nossa sociedade, como uma forma de educar, não só de atender as necessidades como se fosse algo isolado de um contexto de relação.

Eu falo educar e cuidar porque isso reflete o nosso trabalho educacional. Quando a gente fala do trabalho educacional a gente está contemplando o educar e o cuidar, eu não gosto de dividir assim, mas didaticamente precisa, porque senão o trabalho de formação tem o olhar só para o educar e não para o cuidar, e pensando no período integral a gente tem um papel importantíssimo. Nós temos vários furos, de não ter no momento esse olhar para o cuidar: quem ensina por exemplo a criança a comer, comer de um jeito bom. Como a gente aprende a comer, que modelo que a gente tem, se eu não tenho um educador que sente com as crianças?

A educação engloba a transmissão de cultura, de conhecimento, de 
tradição, de valores, de regras de convívio, e nisso está incluída a questão tanto pedagógica, formalizada, de uma transmissão de conhecimento, formal, quanto de um cuidado no sentido de um estabelecimento de vínculo com as crianças, onde especialmente a questão do bem-estar e das relações está incluída.

Quanto mais a educação é compreendida de forma ampla, abrangente, mais o cuidado se relaciona à educação. Então: o cuidado que se preocupa com a relação é formativo porque a criança aprende durante a interação; o cuidado que se preocupa com a inserção da criança na cultura é educativo porque educar é inserir na cultura, é promover a cidadania.

E esse contexto de relação é educativo, no sentido de formar dentro de uma relação. Eles estão super relacionados: não existe cuidado isolado disso, um cuidado que pudesse ser feito por uma máquina. Ele é um cuidar na relação, é um cuidar que em si só já é formativo.

Cuidar tem os aspectos físicos para manter a criança confortável, saudável, bem alimentada, que, quanto menor mais dependente; que ela possa adquirir bons hábitos alimentares, hábitos de higiene e que ela possa lentamente ir se inserindo no mundo da cultura. Então o cuidar é tudo, envolve o educar. Quando eu falo do brincar, a criança tem o direito de brincar, a brincadeira é constitutiva na vida da criança e é parte da cultura, coisas que a gente vai acumulando e vai recriando e vai transmitindo, dentro da brincadeira, a literatura, essa história da tradição oral. São formas que a gente tem de estar transformando a criança num cidadão, num adulto crítico, e o cuidar é isso tudo.

Uma forma de compreender a interação entre cuidar e educar é aquela que identifica nas situações cotidianas de cuidado os aspectos educativos envolvidos. Assim, ao alimentar a criança, ela está sendo cuidada e a parte educativa refere-se ao que acompanha esse momento: a troca entre o grupo, aprender a como comer; no cuidado de higiene, pode-se educar usando esse momento para estimular a linguagem, o desenvolvimento motor.

Só cuidar seria aquela velha história, eu troco a fralda, eu dou banho, eu alimento, mas não estou tentando passar nada no sentido da educação. (...) $\mathrm{Na}$ alimentação, é o sentar na mesa, o usar os talheres, a cidadania, respeitar o amigo, os educadores. Estar fazendo um trabalho para a criança aprender a comer verduras, legumes, frutas, isso é um cuidar, um todo, está ligado, não penso só no cuidar.

Quando eu cuido eu estou educando, quando eu educo eu cuido, um trocadilho aí. Vou dar o exemplo da alimentação. Na hora da refeição, a maneira como eu organizo as mesas, as cadeiras, a maneira como eu preparo o prato, como eи apresento, eи estou cuidando, porque eu estou dando alimentação que é uma coisa importante para as crianças mas é um momento também que eu estou educando, porque eu estou compartilhando 
com outro. No momento da refeição a gente está conversando com eles, as crianças estão juntas, naquele ambiente, um ambiente gostoso, sem muita confusão. Quando eu me preocupo que, pausando a cada colherada, eu estou vendo como a criança está mastigando, ensinando a não ser muito ansios a com a comida, que comer tem que ser um ato de prazer, tem que ser devagarinho, gostoso, bem mastigado. São as duas coisas juntas, eu estou educando e também estou cuidando.

Eu vou trocar o bebê, eu organizo o espaço, levo a mochila, deixo tudo preparadinho; vou conversando com a criança, tocando o corpo dela, ela está numa intimidade naquele momento, vou conversando "olha, agora a gente vai entrar na banheira, vou pôr só o pezinho”, ponho um brinquedo, converso "vou lavar o rosto, a barriga", vou fazendo, falando, estou estimulando a linguagem, o desenvolvimento motor, estou pensando na educação mas também cuidando da higiene da criança. São duas coisas juntas o tempo inteiro.

A integração ou separação entre o cuidado e a educação se constrói na maneira como se organiza o dia-a-dia da criança, nas relações que o educador cria com as atividades.

Quando a gente pensa em projetos englobando a saúde, com o nome projeto se legitima uma série de coisas. Projeto significa que tem um objetivo e tem um produto para demonstrar o que foi aprendido e apreendido pelas crianças. Quando se legitima que a saúde esteja dentro do trabalho educativo via projeto, se torna simplesmente um conteúdo que a criança tem que aprender e saber reproduzir: se lava a mão porque, se escova os dentes. Tem um pedaço importante da informação, mas que a saúde só possa estar na relação do professor com o aluno pela via de um conteúdo, você está de novo numa dicotomia assistência - pedagogia. No cotidiano, o professor só se sente à vontade para trabalhar com a saúde desde que seja dentro de um projeto legitimado por uma atuação metodológica.

Não dá para pensar como duas linhas de trabalho separadas: agora cuidamos, agora educamos. É uma coisa integrada. A idéia que os educadores são os mesmos, inclusive dentro do berçário, os educadores que fazem a troca, dão o banho no bebê, são os mesmos que fazem as atividades de linguagem musical, por exemplo, a idéia é que ambas atividades tenham importância fundamental nesse trabalho, que todas são, não sei se a palavra é essa, mas valor e são educativas.

Tais idéias mostram-se condizentes com concepções mais atuais de desenvolvimento infantil que "situam a criança em seu contexto social, ambiental, cultural e, mais concretamente, no contexto das interações que estabelece com os adultos, crianças, espaços, coisas e seres a sua volta", e que, a respeito das funções de cuidado e educação afirmam "as diretrizes curriculares definem-se também de forma integrada, sem privilegiar um aspecto em detrimento do outro" (Campos, 1994). 
Para que a educadora se torne também um recurso de cuidado, Campos (1994) defende que é necessário um "novo tipo de formação, baseada numa concepção integrada de desenvolvimento e educação infantil, que não hierarquize atividades de cuidado e educação e não as segmente em espaços, horários e responsabilidades profissionais diferentes.

Campos (1994) analisa as características das creches no primeiro mundo e conclui que

"No dia-a-dia da creche, as tarefas de cuidado e educação aparecem de forma tão mais integrada quanto menores são as crianças: 0 adulto, para as crianças muito pequenas e bebês é tanto mais significativo como educador (...) quanto mais estiver desempenhando seu papel de provedor de cuidados, mantendo contato com 0 corpo da criança, sendo carinhoso, transmitindo segurança e aconchego".

Aquilo que é referido como cuidado, no sentido do respeito e da liberdade, é o que dá uma qualidade ao trabalho educacional, promovendo o desenvolvimento e emancipação infantil.

Hoje, a gente não entende mais desse jeito. Dar comida tem que ser uma relação de presença, inteira, de olhar para a criança, de perceber como que ela está se relacionando com a comida, da minha relação com ela, como é importante o meu jeito de estar oferecendo e perceber o que ela gosta e o que ela não gosta, como ela está lidando, permitindo que ela experimente a comida, que ela explore a comida, que tenha até uma relação de escolha, de desenvolver o gosto dela, sem que eu obrigue ou parta do princípio que ela tem que se alimentar. Uma relação cada vez mais de respeito, de propiciar que a criança também se desenvolva, em relação àquilo que ela gosta, a sua autonomia, sua individualidade, sua possibilidade de até recriar essa situação, que é o comer, como come, o que come, para que come.

Conforme já apresentado, as coordenadoras percebem que as educadoras se frustram por trabalhar com crianças muito pequenas. Atribuem isso à falta de formação para o cuidado, que leva a uma separação clara entre cuidar como a tarefa junto às crianças menores e educar como aquilo que ocorre na sala de aula, com as crianças maiores. Buscam superar essa visão com o trabalho de formação.

Isso aparece mesmo, parece que não tem valor, quem trabalha no berçário é diferente de quem está no pré. Eu acho que não. A gente trabalha para que elas [as educadoras] não fiquem com essa idéia, nem uma nem outra, nem quem está no pré desvalorizar o trabalho. Porque na verdade, 0 a 3 que é considerado creche mesmo, é super importante, é a base, é a primeira base.

A R. fez um trabalho, nas reuniões de formação, muito interessante nesse sentido, cuidar e educar, e a equipe, a psicóloga também, todo mundo. São 
duas coisas que caminham junto. A gente não tem que planejar uma atividade só pedagógica, a gente tem que pensar, planejar também a hora do sono, a hora da comida, essas coisas dos cuidados, a gente tem que pensar conjuntamente. Eu sinto que, mesmo hoje, com esse trabalho, tem uma certa frustração, principalmente os educadores que estão entrando agora. Ao longo de um tempo, de estar nessa discussão, colocando coisas, perguntando e questionando alguns momentos, elas vão percebendo isso e tentando entender que eu estou fazendo agora, estou cuidando, estou educando, que trabalho é esse com a criança tão pequena? Mas é difícil mesmo, pela própria formação das pessoas.

Uma situação em que a coordenadora identifica a dicotomia entre cuidar e educar para as educadoras é quando estas se reportam ao cuidado que a família oferece à criança.

Aparecem mais os preconceitos e os conceitos sobre o que seja um bom cuidado no sentido da limpeza, do cuidado com a saúde, menos aqui dentro, e mais quando isso aparece na família. Quando o educador se confronta, por exemplo, com aquilo que ele chamaria de um descuido da família, aí você pode ver um pouco mais como que está ainda dissociado para ele a idéia de assistência, como ainda aparece o ideal de uma criança limpinha [igual a] bem cuidada. A gente vai conseguindo identificar e discutir um pouco isso na hora em que se dão os confrontos entre educador e família, entre uma mãe que cuida bem ou não, um ideal do que seria essa mãe, todas as dificuldades do educador de lidar com a posse da criança "a gente passa o dia com ele, cuida bem, e aí ele volta no dia seguinte com a mesma roupa que foi". Nesse momento, parece que vem à tona de novo como uma questão, a mãe não tem cuidado, a mãe não está olhando por esse lado, isso volta a ser um tema.

$\mathrm{Na}$ expectativa das educadoras sobre o cuidado da criança pela mãe, evidencia-se sua representação sobre a boa mãe. A coordenadora mostra, neste e em outros trechos da entrevista, que ela tem uma atuação freqüente junto às educadoras no sentido de ajudá-las a compreender as mães reais, isto é, as mães como pessoas e não como os ideais esperados pelas educadoras. 


\section{PARA AS EDUCADORAS}

As áreas encontradas foram o cuidado da criança, e relações entre cuidar e educar.

\section{- O cuidado da criança}

O cuidado da criança é referido como o atendimento de necessidades para prover o bem-estar da criança e a atenção para com ela. As atividades descritas como sendo de cuidado expressam a idéia de que as necessidades consideradas são a higiene, a alimentação e a segurança. Embora enfatizado como algo necessário e imprescindível, é descrito como um momento separado, exclusivo e uma etapa preparatória para o momento educativo.

Aprendi muitas coisas, porque até então eu não tinha essa experiência de trocar fralda, essas coisas que a gente, quando é muito nova, não tem noção desses cuidados todos.

Eu passei pelo G1 e G2. A primeira vez que eu peguei um grupo, era lindo mas também terrível, é um grupo que realmente dá a questão dos cuidados.

O princípio da creche é o bem-estar da criança, tudo é centrado na criança. A troca, a alimentação, o sono, como ambiente confortável para a criança. Ela estando limpa, bem alimentada, descansada, você está criando um ambiente facilitador para que você possa propor um outro ambiente de desenvolvimento cognitivo.

Manter a segurança, supervisionar, é cuidar

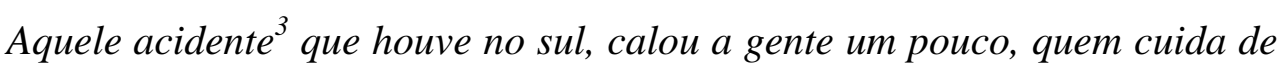
berçário. A gente não conseguiu entender como alguém conseguiu não olhar a necessidade daquele grupo que era tão pequeno e que não teve uma supervisão de um adulto. Como um adulto pode não pensar na dimensão do perigo que o grupo poderia sentir, e que é bem peculiar desse cuidar.

O cuidado na creche é diferente do cuidado em casa: é um cuidado profissional, fundamentado em princípios científicos e em rotinas institucionais.

Quando os pais chegam na creche, eles estranham, porque na verdade aquilo não faz parte da rotina de nenhuma casa. É um cuidado extremo que a gente tem com os filhos de quem nos foi confiado, é uma rotina profissional, é uma rotina da instituição. Em casa, você troca a criança na sua cama. É tão diferente: criança de 9 meses não come bolacha, não come

\footnotetext{
${ }^{3}$ Refere-se ao incêndio ocorrido em junho de 2000, em uma sala de uma creche municipal em Uruguaiana-RS, no qual morreram carbonizadas 12 crianças (de dois a três anos de idade). A causa do acidente foi um aquecedor elétrico utilizado na sala onde as crianças dormiam, sem supervisão de um adulto. In: Villanova M. Todos mortos. Veja, edição 1655, 26:48-50.
} 
bolo, não come pão, tira a gema, tem uma rotina de alimentação, queijo tem que ser o minas, menos de 1 ano e meio, nunca. Em casa, um bebê de nove meses, dez meses, o irmão mais velho do lado, você pega um pedaço. Na verdade é outros quinhentos.

As crianças pequenas demandam mais cuidado que as maiores

O cuidado que você tem com a criança do berçário não é o mesmo que você tem com a criança do G2, do G3. Tudo é pensado nos mínimos detalhes, um brinquedo caiu no chão, esse brinquedo tem quer ser tirado do berçário porque tem que ser lavado, saiu da boca de um, você tem que tomar cuidado.

Mas, para todas as crianças, a responsabilidade de garantir a segurança física demanda atenção, observação, organização do espaço físico, uma série de cuidados para a prevenção de acidentes.

Quando a criança se machuca na creche, é uma coisa impressionante. Quando você vai relatar para o pai, a impressão que eu tenho é que eles passam um filme na cabeça deles, na hora, balança a cabeça "eu não acredito"... E você vai tendo que relatar com cuidado "eu estava bem pertinho, não estava longe, ela estava brincando". Você não pode se colocar culpada, mas você é responsável por aquela criança naquele momento, ele confia o filho dele para você. A gente se sente muito mal porque acontece esse tipo de coisa, mas a gente tem evitar ao máximo.

A percepção da responsabilidade pela segurança reitera a concepção do cuidado como função da educadora, tal como declara Kulhmann Jr (2000):

"A polarização entre assistencial e educacional opõe a função de guarda e proteção à função educativa, como se ambas fossem incompatíveis, uma excluindo a outra. Entretanto, a observação das instituições escolares evidencia que elas têm como elemento intrínseco ao seu funcionamento o desempenho de guardar as crianças que as freqüentam.(...) As instituições educacionais, especialmente aquelas para a pequena infância, se apresentam à sociedade e às famílias de qualquer classe social como responsáveis pelas crianças no período que as atendem."

Considerando que a escola não forma para o cuidado, podemos inferir que a concepção de cuidado que as educadoras têm ao ingressar na creche seja a do senso comum. Já, a atual representação resulta da assimilação de um novo conhecimento, corrente na creche e fortemente colocado ou garantido pela coordenação.

As educadoras percebem que a relação com as crianças na creche é diferente da relação com os próprios filhos (ser mãe é diferente de ser educadora)

Eu dou livro, eu incentivo, mas eu não consigo fazer com que eles pintem, 
não entusiasmo tanto como eu consigo fazer com as minhas crianças que eu cuido devorem um livro, as figuras que eles vêem, e se debruçam. O que a gente faz profissionalmente, não é o retrato do que faz com seu filho.

Santo de casa não faz milagre. Quando eu trabalhava no berçário, minha filha estava com 6 anos e ela estava começando a aprender a ler. [no berçário] se eu colocasse o livro assim os bebezinhos vinham em cima prá tirar então ele tinha que ficar assim. Eu fui ler, fazer igual, a minha filha falou "ih mãe, não é assim que a S. faz, ela põe no chão. E vai abrindo para todo mundo ver", "mas você está sozinha", "mas tem que ser igual a da S.", eu tive que contar a história igual a $S$.

Quando a realização dos cuidados ou as interações com as crianças apresentam-se difíceis, as educadoras vivenciam vários sentimentos que as mobilizam para a busca de respostas. As situações mais corriqueiras são a da recusa da criança em ficar na creche no horário da chegada ou em alimentarse e o choro

Eu já fiquei muito mal de receber a criança e a criança não querer ficar com a gente. Mas aí tem a coisa da equipe porque, por exemplo, quando a parceira da gente vê que a gente não está legal, fica no lugar da gente. Já aconteceu de ela falar prá mim "vai lá, segura um, porque eu não estou legal, acho que eu não vou dar conta disso, a criança vai chorar mais, eu vou ficar mal"

Na alimentação, o sentimento às vezes pega. Quando a criança come bem você está feliz. Quando a criança recusa, a gente fica com aquele sentimento: como eu posso ajudar, como eu posso contribuir? Você fica preocupada, querendo que ela coma.

Muito triste porque o que é que eu faço nessa hora?

Esses depoimentos explicitam que há necessidade de aprofundar muito mais, ainda, o que seja o cuidado. Eles mostram uma internalização de responsabilidade (ou sentimento de culpa?) com as recusas da criança e um certo desconhecimento sobre como cuidar nesses momentos, contrariando o discurso da coordenadora que a forma da educadora lidar com essas situações é diferente da maneira como as mães lidam.

Aprender a lidar com essas situações difíceis demanda transformação, amadurecimento, conhecimento sobre o que fazer.

A lagartinha é o processo de transformação das educadoras, como cada uma está entendendo a coisa, para que a gente depois possa chegar no coletivo de uma forma mais tranqüila. Tem a lagarta e a borboleta como um processo de transformação mesmo. Quando a gente atravessa esse processo, a gente amadurece mais, não que seja totalmente fácil, mas a gente consegue equilibrar mais essas questões. 
É um aprendizado nosso. A gente vai percebendo que dá prá ser mais firme, dizer "pode ir trabalhar tranqüila que daqui a pouco ela vai parar de chorar e vai ficar legal". Isso surpreende a criança também, porque naquele momento ela quer deixar a mãe mal mesmo, e a gente diz "pode ir sossegada que daqui a pouco ela vai ficar legal, ela vai parar de chorar". Mas é um processo de aprendizado, e não é fácil.

\section{- Relações entre educar e cuidar}

Todo o grupo aponta as atividades de cuidado como parte de seu papel, mas percebe-se que buscam encontrar e valorizar aspectos pedagógicos presentes no trabalho com a criança pequena, para valorizar o próprio trabalho. A afirmação da educadora, na avaliação final dos encontros, deixa visível que ela também carrega uma visão de cuidado como uma coisa "menor".

Não pensei que a discussão fosse tão profunda, tão rica; o cuidar da criança, sinceramente eu pensei que fosse mais superficial

As educadoras que têm atuado mais junto ao berçário magoam-se com as manifestações das demais, de que o trabalho com as crianças pequenas é centrado na higiene, isto é, no cuidado.

Na hora da escolha, o mais difícil era compor o berçário, porque ninguém queria esse grupo. Havia um preconceito dos próprios educadores. Havia briga pelo G2, pelo G3, pelo G4, pelo G5, pelo G6. Mas berçário, quando alguém levantava a mão e falava "eu quero berçário", quase era aplaudida, aclamada. Numa reunião de módulo, que nossa coordenadora estava cobrando planejamento, a educadora falou "o planejamento do berçário é, cocô, xixi, cocô, xixi, cocô, xixi”, e aquilo pegou muito forte nas educadoras do berçário. Faz parte do nosso dia, mas há um outro conteúdo que os outros grupos não viam.

Para contrapor-se a esse preconceito, buscam delimitar "outros conteúdos" que possam demonstrar que a dimensão pedagógica do processo educacional começa no berçário.

Foi uma conquista da creche central, eu trabalho lá há 11 anos, nem sempre a gente teve esse olhar de que o módulo 1 até o módulo 3 a criança está aprendendo, sem ter aquela coisa do assistencialismo e do pedagógico. É um processo, que começa lá no berçário.

Foi mais investido, para mostrar como era o trabalho. Que as crianças do berçário experimentavam o mesmo material que uma criança do módulo 2 , dos outros grupos. Talvez não com a mesma propriedade por causa das diferenças etárias, mas ela mexe com o mesmo material, há um trabalho pedagógico, que não era visto pela própria equipe. 
Tem parte pedagógica. Se você não trabalhar a atenção, a concentração da criança com histórias, com trabalho pedagógico propício prá essa idade, quando chegar no pré, ela não vai ter concentração, ela não vai ter bagagem prá ser alfabetizada, no concreto.

No berçário, as pessoas visam só o cuidado mas há outro trabalho por trás complementando. Porque a criança chega no G2 pegando livros, sentando e conhecendo aquele livro? Porque no berçário ela teve uma carga de experimentação, de estimulação muito grande, e a gente como equipe esquecia de ver. Porque que ela chegou com essa bagagem? Porque teve um investimento.

É importante assinalar que a ênfase recai sobre a dimensão pedagógica, particularmente no que se refere às atividades que visam o desenvolvimento de um certo conteúdo ou área de conhecimento tal como na escola. Por isso, sentem que a lei e as pesquisas não abordam a educação da criança pequena.

[O berçário] está melhorando. Não é o ideal, ainda não. Porque você pega a própria lei, pega a LDB, a educação infantil é de 3 a 6 anos, quer dizer, não existe educação infantil de 0 a 3? Não existe. Você vai pesquisar as artes visuais de 0 a 3, não tem. O próprio pesquisador, é uma coisa que está enraizada, o pesquisador não pesquisa de 0 a 3 anos, não interessa prá ele pesquisar de 0 a 3 anos.

Não são mencionados outros aspectos relativos à aprendizagem infantil e que constituem ações educativas e de cuidado tais como o movimento, o equilíbrio, o toque, o colo, a construção da identidade, as oportunidades para explorar, o estabelecimento de relações, a descoberta do próprio potencial, das próprias competências, a percepção de si como ser de valor.

Nesse sentido, é contraditório que as educadoras questionem o fato de que os pais e a sociedade em geral atribuam demasiado valor à dimensão pedagógica. Elas entendem que tal atribuição de valor sustenta-se na percepção de que a nossa sociedade privilegia o desenvolvimento da área cognitiva.

[O mercado de trabalho] não quer cidadãos críticos, quer mão de obra qualificada, produtiva. Tem que saber inglês, mais não sei o que, prá poder se inserir no mercado de trabalho. É difícil, como pai, ver isso com clareza. Por isso tem o judô com 2 anos, inglês com 2 anos, computação. Por que? Porque quando ele estiver na fase adulta, ele vai ter uma chance no mercado de trabalho, que é uma lei selvagem. Falar de afetividade, do próprio brincar, de desenvolver a cooperação, não é valorizado.

Há uma antecipação. Há um tempo atrás, com 30 anos, a pessoa estava madura profissionalmente prá entrar no mercado. Hoje, entrar no mercado é muito antecipado, por que? Porque com 14 anos o cara domina uma 
internet, ele cria empresas de internet e administra, e aí o que acontece? Você tem priorizado isso, não é a qualidade da vida da criança, não é a qualidade no brincar, mas o que ela vai conseguir, com uma bagagem $x$. Então você escuta o pai preocupado, e, como pais, a gente sabe que também nos passa pela cabeça, "meu filho tem que saber inglês, se ele não souber inglês, com 14 anos, ele vai ficar boiando numa escola".

Apenas uma educadora relacionou as atividades de cuidado com o aspecto pedagógico, considerando que a criança aprende durante tais atividades e que essa é a concepção presente nas creches da universidade.

Quando a gente discute a coisa da escola, da educação, a creche frustra um pouco. Eu não entendo que o bem-estar não seja pedagógico, porque a criança está aprendendo. Se ela está aprendendo a escovar os dentes, está aprendendo a trocar de roupa, então isso é um processo pedagógico. Não é uma coisa isolada da outra "agora você está prontinho, você está trocadinho, arrumadinho, então vai fazer a tarefa". Algumas pessoas, não dentro das nossas creches, mas eu já trabalhei fora, eu vejo um pouco isso "eu quero ser professor". Quer dizer, a hora do trocar, de dar comida, ele acha que não está sendo professor, eu já vivenciei isso. A pessoa isola mesmo, essa coisa do trocar, do alimentar, não deixa o cara ser o educador. Prá mim o educador é tudo isso.

Entretanto, ela foi contestada pelas demais que afirmaram não ser essa a visão unânime das educadoras, mesmo naquelas creches.

Eu já passei pela experiência de berçário, e o conhecimento que eu tive foi muito gratificante, de pegar uma criança de 4 meses e acompanhar toda a evolução dela. Só que fica uma coisa restrita porque há um preconceito até entre nós. Porque? Porque há uma conotação de que o seu trabalho não é tão importante quanto o trabalho do pré. E está acontecendo dentro de uma creche da USP, onde está sendo combatido isso. A própria literatura, não há um registro em relação ao trabalho e não se fala que a fase inicial da criança é que vai ser importante quando ela estiver com 7 anos. Não há registro quase de como se trabalhar no berçário, qual é a evolução da criança, o que a criança é capaz de fazer, o que o educador pode fazer para desenvolver isso.

A despeito das divergências, o que há de comum nesses discursos é a idéia que a importância do cuidado se dá pelo aspecto de relacionar-se a uma aprendizagem. Quer dizer, não se atribui um valor independente ao cuidado.

Essa controvérsia aparece também na literatura. Por exemplo, Dutoit (1995) define como educacional "o conjunto das atividades desenvolvidas nas áreas de pedagogia, psicologia, saúde e nutrição, que caracteriza o trabalho com crianças de 0 a 6 anos de idade, em instituição de período integral". Com essa afirmação, a autora inclui todas as ações de cuidado na dimensão 
educacional excluindo, assim, a possibilidade de pensar o cuidado como categoria individual e independente da educação.

O que pode justificar essa visão é que há uma lacuna na sistematização do cuidado, dificultando que ele possa ser objetivado, mediante planejamento, com definição de objetivos, estratégias e avaliação, considerando os aspectos só do cuidado, sem atrelar sua importância ao aprendizado de algo. 


\section{- A CRECHE e A FAMÍLIA}

Este tema inclui as expectativas, percepções, sentimentos e ações relacionados às interações entre a equipe da creche e a família, e medidas para favorecer a interação entre a creche e a família.

\section{PARA AS COORDENADORAS}

A interação efetiva entre creche e família é imprescindível, uma vez que estas se constituem em duas instituições distintas, mas que compartilham um objeto comum: os cuidados e a educação da criança. No discurso abaixo, evidencia-se que a responsabilidade na busca de soluções para atender as crianças não é exclusiva de pais nem de educadoras, mas sim compromisso de todos os agentes envolvidos: criança, família e creche.

Se uma criança está com dificuldade, chora muito, isso não é um problema dela, não é ela que não se adapta. É um problema nosso - dela, da família e da creche - achar um caminho. A gente tem que achar e consegue achar um caminho com todas as crianças. Isso é um princípio, a creche pode ser boa prá todas, não há restrição "ela não se adaptou é melhor que vá procurar outra escola".

Embora a relação com as famílias seja fundamental e constante, as interações nem sempre são fáceis. Como fatores que dificultam essa interação, destacaram-se comportamentos da família, bem como comportamentos dos membros da equipe da creche. Foram trazidos exemplos de medidas para favorecer a interação, como apoiar os pais e ajudar as educadoras.

\section{- Expectativas, percepções, sentimentos e ações relacionados às interações entre a equipe da creche e a família}

O primeiro fator lembrado como conflituoso foi a "competição" da família com as educadoras.

A relação com as famílias é fundamental para você poder lidar. Mas tem a competição da própria família com o educador. A gente que viu, às vezes, o primeiro dentinho nascendo, os primeiros passos. É delicada essa relação. Em toda reunião surge alguma coisa nesse sentido.

Bonomi (1998) postula que o cuidado da criança pequena, compartilhado por vários adultos, é uma experiência conflitante, uma dinâmica relacional complexa, que assume "contornos e sombreados diferentes, se os 
pólos adultos do relacionamento forem os pais (pai e mãe), ou então pais e avós ou parentes, ou ainda pais e babás ou educadoras de creche". Esse aspecto deve também ser lembrado para ajudar os trabalhadores de creche em suas análises e encaminhamentos.

Mantovani e Terzi (1998) trazem à tona uma reflexão que pouco tem sido vista na nossa realidade de atendimento em creches. Problematizam a questão da adaptação da criança à creche aprofundando também o significado dessa inserção para os pais. Assim, ressaltam que, quando se trata de crianças pequenas, no primeiro ano de vida, os pais provavelmente encontramse cheios de dúvidas sobre a própria adequação para construir um relacionamento com seu filho. Por isso, a inserção da criança pode ser uma experiência traumática para os pais, alterando a relação com a criança e deixando-os inseguros e ambivalentes. Explicam que:

"Se esse processo for interrompido, ou mostrando ao pai que ele não é essencial para o desenvolvimento feliz da criança, ou devolvendo-lhe uma criança que se torna um pouco estranha, que muda rapidamente, sem que a mãe ou o pai possam seguir e reconhecer as etapas dessa mudança, provavelmente veremos nos pais comportamentos de crise bem parecidos com os que estamos acostumados a estudar na criança: apego ansioso ou recusa incoerente - a mãe sente-se abandonada, sente-se inútil e vive incoerentemente a experiência da separação da criança." (Mantovani e Terzi, 1998)

Partindo da premissa que os pais têm outras angústias, conforme explicam Mantovani e Terzi (1998), as intervenções da creche junto a eles precisariam contemplar tais angústias. Nas afirmações a seguir, evidencia-se que está sendo percebido que pode haver outras causas para as dificuldades vividas pela mãe, mas não há explicitação de uma ação correspondente para amenizar tal dificuldade.

Às vezes, a gente acha que o tempo que ela precisa já está bom, mas para a mãe ainda não está. Um bom cuidado é também atender a mãe, a ansiedade dela. Às vezes, a criança é mais rápida do que a própria mãe. É fácil entender isso, a criança está crescendo, e a mãe ainda quer aquele bebê...

Em continuidade à manifestação de que a mãe pode precisar de um tampo maior para conseguir separar-se da criança, enfatizou-se a necessidade de estar atenta ao momento de colocar limites a comportamentos indesejados por parte da mãe.

Você também tem que estar ligada na hora que você vai por um limite para 
a mãe: "é creche aberta, mas aberta não significa invadir espaços, quando a criança está se adaptando, interromper, porque aí ela vai voltar”.

Embora os pais precisem aprender a compreender o ponto de vista dos profissionais e a respeitar as normas da creche, a marca mais forte no depoimento acima é a de reforçar a constatação de que não está sendo pensado como atender a mãe nas suas próprias dificuldades. Quando a mãe invade o espaço da creche, ela pode estar buscando resposta a algum medo ou fantasia a respeito do atendimento ou querer garantir, para si mesma, que ela não perdeu o acesso a seu filho. Se esse comportamento é visto somente sob o prisma da norma da creche ou da manutenção do bom funcionamento das atividades, não se permite a possibilidade de um espaço para falar sobre as razões da mãe para esse comportamento.

Mello (1999) explica que o modelo de creche aberta é aquele "que possibilita o exercício de confrontos, negociações e, portanto, a troca de afetos", e que, nesse modelo, os profissionais são levados a exercitar "a aceitação das diferenças, a tolerância e a cidadania". A autora segue elucidando que os conflitos entre a creche e a família tornam-se mais explícitos, o que é "uma das ferramentas disponíveis para se trabalhar a relação creche-família".

Quando a mãe não se mostra de pleno acordo com as condutas da creche, seja agindo como se as ignorasse, seja questionando-as, entende-se que ela está interferindo ou cobrando algo, não se comportando como esperado.

A mãe passa no parquinho e fala "você está descalço, põe o sapato". Ela está interferindo. Ele está descalço porque nós deixamos, porque ele estava brincando. Não é que ela quer interferir, é que ela nem lembra que nós estamos vendo tudo. Se a mãe chega prá educadora e "por que não fez isso?", você tem que saber lidar com a cobrança e, às vezes, você não sabe ou naquele momento você não está boa. E mesmo se você vai cobrar alguma coisa, como a mãe reage.

No momento em que a mãe age de uma forma não idealizada, em que ela concretiza-se, torna-se uma mãe real, parece que a equipe se desestabiliza, tendo que lançar mão de regras e limites, o que denota que a mãe real foi percebida como desviante.

Uma maneira de explicitar a expectativa da equipe quanto à parceria com 
a família é afirmando a necessidade de que haja uma continuidade do que é realizado no serviço. Aparece em exemplos que contam condutas impróprias dos membros da família, como desconhecimento ou desrespeito às normas da creche e falta de colocação de limites a comportamentos indesejados da criança.

\begin{abstract}
A gente faz um trabalho "não pode sentar na mesa. Tem a cadeira, a mesa não é lugar de sentar, porque você almoça, faz desenho”. A mãe chega e senta na mesa, ou põe ele sentado na mesa para por o sapato. As regras e as normas, às vezes é difícil mesmo de seguir. O horário de entrar é até tal hora, o horário de buscar é tal. Quando passa dos limites você tem que [falar], e isso a gente também está educando, eu acho que você está mostrando isso para criança e a mãe tem que estar passando também. $\dot{E}$ um trabalho conjunto, que a gente quer que seja feito da melhor forma.

Algumas vezes é difícil, porque você tem um jeito de lidar com a criança, $e$ com a mãe presente não adianta. Várias vezes eu tive atrito porque eu pus o limite na criança na frente da mãe. Não na adaptação, na adaptação é outra situação, mas uma criança já mais do que adaptada. [teve um caso] quando a mãe chegava, imediatamente a criança batia no amigo. Eu achava que a mãe tinha que interferir e ela não interferia. Teve um momento limite em que ele falou para a mãe "peraí que eu vou bater no outro", e ela não tomou conhecimento. Aí eu falei duro com ele. Depois, claro, conversei com a mãe. Nenhuma mãe gosta, evidentemente, que você dá uma bronca no filho na frente dela.
\end{abstract}

Consoante Bondioli e Mantovani (1998), no trabalho da creche lida-se com problemas delicados, no que diz respeito ao encontro creche/família. Os pais precisam dividir a responsabilidade educativa e a criação da criança, sem renunciar a seu papel, fato que desencadeia reações fortes, muitas vezes ambivalentes e difíceis de serem decodificadas. Para o enfrentamento desses problemas, segundo as autoras, "é clara a necessidade de uma supervisão e de um suporte constante por parte de órgãos técnicos de coordenação e, periodicamente, de especialistas".

No tocante à situação das creches do estudo, a supervisão e o suporte são oferecidos pelas coordenadoras, o que implica um perfil profissional articulado e complexo (Saitta, 1998).

Além de serem capazes de administrar um complexo de competências técnicas e administrativas, conforme descritas por Saitta (1998), muitas das quais também foram apontadas pelas coordenadoras durante as entrevistas, foram abordados aspectos que se configuram como da ordem da afetividade e 
que demandam o exercício de auto-conhecimento. As interações próximas e constantes com as crianças geram envolvimentos emocionais que podem tornar confusa a definição dos limites profissionais do relacionamento.

No contato com as crianças, é inevitável querer carregar para sua casa, querer ter uma importância para ela. Eu também já vivi isso algumas vezes, de encontrar as crianças na rua, por mais que eu saiba que lá eu não sou a теsma, porque aqui eи estou dentro desse lugar e isso organiza minha presença para a criança; na rua ela se esconde, ela não vem me abraçar do mesmo jeito que ela me abraça aqui. Quase como se não tivesse lugar para você com a criança nessa hora, porque ela está com a mãe dela e com o pai. Você já não é mais a pessoa que você é dentro da creche, onde ela vem, abraça, quer contar, falar, fazer um monte de coisa com você e você parece importante só porque é você. Lá fora não é assim. Eu acho super difícil quando eles mudam de grupo, que eles esquecem... eu fico imaginando para as pessoas que têm um vínculo mais forte, como é difícil, para quem trabalha ali todo dia.

No intento de evitar que o envolvimento emocional torne-se uma barreira para a interação profissional com os usuários, um aspecto a considerar na relação é diferenciar o papel da educadora frente ao materno.

Quando você cuida da criança de outra família, você tem que cuidar justamente para que você não queira substituir para a criança uma mãe $e$ um pai.

A respeito do comportamento das educadoras diante da família, as coordenadoras verificam que também há dificuldades. Mesmo propostas já consolidadas, como a permanência na creche da mãe ou outro familiar em quem a criança confia, durante o período de adaptação, nem sempre são acolhidas tranqüilamente. Às vezes, essa presença incomoda as educadoras, que se sentem vigiadas e até estimulam a saída precoce da mãe nessa fase.

Por mais que a gente fale que a família precisa ficar aqui na creche, por mais que a gente trabalhe isso com o educador, ele não vê a hora da família sair. Para alguns adultos, é um momento difícil. Além do grupo que trabalha aqui, é mais uma pessoa e uma pessoa que está de olho. Afinal de contas, quem somos nós, qual a nossa competência? Sei lá o que passa na cabeça deles, uma certa desconfiança, se vamos dar conta, se vamos cuidar direitinho. Às vezes, eu sinto que tem um certo constrangimento, um certo incômodo com a presença.

Bonomi (1998) esclarece que a presença do pai, durante a inserção, comporta, "na subjetividade da educadora, não só o risco de que a criança tenha dificuldades e que isso seja debitado pelo pai a sua pessoa, como também o risco de que o pai assista a episódios da vida da creche que influam 
negativamente em seu juízo: crianças que choram, momentos de confusão". Assim, embora racionalmente considerada necessária, essa presença é emocionalmente percebida como incômoda "e essa experiência, na fase inicial do relacionamento, funciona como marca negativa mesmo no relacionamento sucessivo. Se a ajuda recíproca não surgir nessa fase, corre-se o risco de ela não surgir mais" (Bonomi, 1998).

É oportuno, ainda, atermo-nos à frase "Sei lá o que passa na cabeça deles, uma certa desconfiança, se vamos dar conta, se vamos cuidar direitinho". Além de corroborar que há uma razão para as educadoras desejarem a breve saída dos pais, gerada por eles mesmos, ao apresentar a desconfiança como uma conjetura (sei lá o que passa na cabeça deles), também se demonstra que não há um processo de comunicação direta a fim de buscar conhecer o que os pais pensam e como se sentem nessa fase da adaptação.

Essa situação assemelha-se à vivida pelos trabalhadores dos serviços de saúde com as mães/pais acompanhantes.

Revelou-se que uma das razões para divergências entre família e creche é que há uma expectativa na equipe acerca do cuidado que deveria ser oferecido à criança pela família e quando a realidade não corresponde a essa expectativa a família é vista como não capaz, não boa.

Como se uma mãe não pudesse, ao mesmo tempo em que cuida da sua criança e tem uma preocupação maternal com ela, ser a mesma mãe que não lava essa criança. Porque a maternidade não necessariamente está em manter a criança limpa. Pode ser da maternidade desta mulher manter essa criança suja, porque isso deve ter uma função para ela. Isso não quer dizer que entender isso seja aceitar esse mau cuidado, vamos dizer, com a limpeza. Mas é colocar isso numa certa dinâmica, e não ficar como um "padrãozinho" do que deve ser uma boa mãe, um bom pai, uma boa criança, um bom professor. Eu acho isso ainda muito difícil. Ainda é uma questão que fica permeando a maneira com que as pessoas tentam se organizar para trabalhar com as crianças, para trabalhar com as famílias, para trabalhar com seus próprios sentimentos...

Conforme Bonomi (1998), quando a criança freqüenta a creche, os pais estão continuamente expostos ao juízo dos outros e, de certa forma, "devem demonstrar continuamente que merecem o atributo de bons pais (...) e a diversidade no seu comportamento entre creche e casa é potencialmente 
objeto de confronto entre capacidade e competência dos pais e capacidade e competência das educadoras".

Pode-se verificar a ocorrência de expectativa semelhante, a respeito dos comportamentos maternos/paternos, em outras circunstâncias. Piccolo (1998) encontrou, em um grupo de trabalhadores de enfermagem de um hospitalescola de São Paulo, uma forte tendência a classificar as mães a partir de suas concepções sobre ser mãe e a agir para com elas em função dessa avaliação.

Se a relação entre a creche e a família constrói-se com base em um estereótipo, significa que ela não está considerando a diversidade de formações culturais e as conseqüentes diferenças de valores e práticas. Mais do que isso, ao rejeitar a cultura da família, postula que a única forma correta de agir para com a criança é a da creche.

A equipe apresenta um discurso sobre as relações entre a creche e a família que ainda não está totalmente introjetado, haja vista as contradições que se evidenciam na idéia que se mantém entre as trabalhadoras de que 0 cuidado e a educação oferecidos na creche são melhores do que os oferecidos pela família.

\begin{abstract}
A gente tem um discurso que é "creche é creche, família é família". As pessoas entendem um pouco mais que são instituições que cuidam do mesmo objeto, mas que partem de lugares muito diferentes. São relações institucionais, tanto na família quanto na creche, há um atravessamento de uma série de questões culturais, econômicas, sociais, mas são universos diferentes. O que se faz aqui não se estraga na família. Por mais que se veja aquela família como um espaço onde o cuidado, a preocupação com a criança, não está em primeiro plano. $O$ discurso diz a respeito dessa separação, mas, na prática e na entrelinha, ainda tem uma certa idéia de que a família devia ser uma continuidade da creche. Um trabalho de parceria, que não é uma parceria, mas é uma reprodução lá do que se dá aqui. Que aqui é o espaço do saber sobre educação, sobre cuidado, sobre criança, sobre como trabalhar.
\end{abstract}

Piotto et al (s/d) afirmam que os educadores "acabam adotando uma postura, muitas vezes inconsciente, de superioridade em relação aos pais". Ora reclamam deles, dizendo que não participam e não continuam em casa os trabalhos iniciados por eles, ora desculpam-nos, dizendo que os pais "não têm condições". Para as autoras, embora essas posições sejam contrárias (acusação X pena), "refletem uma postura de contraposição do educador, 
numa tentativa clara e desesperada de se diferenciar dos pais e valorizar seu papel" (Piotto et al, s/d).

A coordenadora percebe que os pais incorporam essa idéia de que a creche seria a depositária do conhecimento, a instituição capacitada para "falar sobre a criança".

A gente vai vendo isso refletido nos pais. Por exemplo, de eu chamar para conversar sobre a criança, e o pai dizer "mas fala você, porque quem sabe dela é você", legitimado com "mas você passa 12 horas com ela". Mas, $e$ as outras doze e os finais de semana e aquele contato que você tem e o saber que é totalmente diferente, de uma família para uma criança? Isso é fruto de uma certa posição da instituição, que tem cartazes, palestras, falas, que tem uma maneira de lidar com a criança, que cria toda uma idealização de si própria e, enfim, também tem um bom trabalho. Mas tem um pouco isso: uma produção de um saber, profissionalizar aquilo que é o cuidado de uma criança, transformar só o profissional como quem possa falar o que é correto.

A coordenadora enumera vários fatores que podem influenciar a percepção paterna, mediante comunicação implícita dessa idéia da creche como o lugar do saber sobre a criança. Além desses fatores, é cabível pensar em outras possibilidades para explicar este efeito, de certa forma, intimidatório, exercido sobre a família. Por exemplo, a análise acerca da comunicação interpessoal - se dialógica ou prescritiva; a forma como são propostos os cartazes, as palestras - se por decisão da creche ou conjuntamente com os pais; como são estimuladas e acolhidas as idéias dos pais.

No discurso seguinte, a coordenadora manifesta-se conhecedora das diferentes concepções sobre cuidado e educação da criança que podem permear a creche e a família, identificando-as como origem de atritos entre essas instituições.

Tem que ter o respeito pela outra pessoa, você tem que pensar que ela pensa de um jeito diferente e, às vezes, isso dá atrito mesmo. Os pais não podem chegar aqui e falar "eи quero que você mude, eu não quero o construtivismo, eu quero o tradicional". Eu, também, não posso chegar e falar "olha, eu quero que na sua casa você faça isso com ela". Então esse respeito tem que ter.

Esse depoimento deixa transparecer uma noção exatamente oposta à apresentada por Ghedini (1994), que afirma: 
"Ao estabelecer contato com os pais, é preciso, por um lado, criar uma situação aberta à comunicação, estar pronto para ouvi-los e entender seu plano educacional (...) e considerar o contexto social, cultural, econômico das famílias".

Contrariamente, na visão da coordenadora, evidencia-se uma falta de espaço e de acolhimento para as expectativas e idéias da família. Bonomi (1998) diz que parece haver regras implícitas, no relacionamento entre educadora e pai, de que um não deva fazer incursões no território do outro, e ambos mantém bem separados as próprias posições e os âmbitos de intervenção sobre a criança. Conforme algumas falas registradas neste trabalho, poderíamos sintetizar essa idéia na seguinte frase: "os pais não interferem no trabalho da creche e a creche não interfere no trabalho deles".

O discurso a seguir vem reforçar a percepção de que a explicitação de expectativas da família, contrárias à proposta da creche, é recebida como descabida.

Algumas mães cobram coisas que a gente acha um absurdo. A nossa linha de trabalho é o construtivismo, é você estar respeitando mesmo a criança, o ritmo dela. A mãe acha que ele tem que estar alfabetizado. É difícil você fazer ela entender que ele vai sair da creche e ele não está escrevendo e lendo correntemente, mas está pronto, no primeiro ano ele vai deslanchar tranqüilamente.

Essa coordenadora vislumbra que a Associação de Pais poderá melhorar o relacionamento família/creche. Fala da troca, a compartilha que será possível com a criação da Associação, mas revela uma contradição quando afirma que, por intermédio da associação, os pais poderão então "compreender e aceitar as normas" e deixar de cobrar coisas "absurdas" como contestar a metodologia do trabalho pedagógico.

A lei de diretrizes e bases exige que tenha associação, nós estamos criando a associação de pais e educadores. É bom, porque vai ter uma troca maior, um grupo que vai estar mesmo pensando em tudo, e nessa coisa de compreender as normas, de aceitar.

Novamente emerge a visão da creche como aquela que sabe o que é melhor e que, portanto, os pais têm que se submeter. Não se aventa, por exemplo, a possibilidade de mudar as regras com a organização dos pais na associação.

Outra forma de dizer que o profissional sabe o que é o correto é oferecer 
coisas para os pais, visando que melhorem sua atuação junto à criança e sua relação com a creche, como palestras, textos, sugerir leituras.

A gente tenta fazer algumas coisas, dando palestras para os pais, trazendo gente que pode estar ajudando. E a gente até gostaria de ter mais, eu estou sempre colocando artigo, qualquer coisa que apareça, que eu achei interessante, por no mural, falar para os pais lerem. São poucos os que param no mural para ler. Mas não importa! Você tem que estar falando e pondo.

Mas há visões diferentes. Outra coordenadora lamenta que a postura da família diante da creche seja predominantemente de submissão, em detrimento de uma participação maior na definição de objetivos e propostas como decorrência de gratidão ao atendimento que, além de bom, permite-lhe manter sua subsistência, pois libera a mãe para continuar trabalhando.

Para os pais, ainda, a creche é um mal necessário, atrelado à necessidade do trabalho da mulher. É totalmente diferente de lidar com os filhos de docentes ou pessoas que tenham escolhido uma carreira. Mas com a clientela que tem nível econômico baixo e a mulher é um complemento da renda, não necessariamente fez uma escolha profissional, se [a creche] é um bom espaço, rendem uma gratidão tão grande que é impossível criticar. Por exemplo, é impossivel vir aqui e dizer "não, não concordo com isso que vocês estão fazendo, eu quero que vocês pensem nisso. Eu penso de outro jeito a educação da minha filha, do meu filho". Não, rende uma gratidão extrema. Eu acho isso delicado, é uma coisa que a gente não consegue reverter, ou não consegue pensar o suficiente para fazer outra proposta.

Essa postura dos pais denota que a creche é incorporada como um benefício, mais do que como um direito de cidadania. Pode também significar que eles sintam-se inseguros quanto à sua capacidade de sugerir qualquer tipo de ação para um serviço proclamado como de qualidade.

Em relação ao aspecto do direito, o fato de não haver garantia do atendimento a esse direito certamente leva as famílias a sentirem-se impelidas a somente agradecer, pois muitas outras sequer alcançarão a possibilidade de terem uma vaga. Conforme explicitado na metodologia, há um processo de seleção para ocupação das vagas nas creches, tendo em vista que a demanda é muito superior ao número de vagas ${ }^{1}$.

\footnotetext{
${ }^{1}$ Na seleção para 2001, havia 960 crianças inscritas para um total de 73 vagas nas creches Oeste e Central juntas, conforme informou a Diretora da Divisão de Creches da USP, em 18 de junho de 2001.
} 
Ademais, acrescenta-se o fato de que vivemos em um país onde há um histórico de descaso com os direitos sociais da população, fato que influencia a ocorrência de comportamentos reivindicatórios.

Ghedini (1994) explica que

"Sempre que duas instituições se encontram - neste caso a família e a creche inevitavelmente colocam em marcha uma dinâmica complexa de interações (...). Cada instituição possui, além de objetivos bem definidos, também alguns "escondidos", dos quais o mais importante é desempenhar sua própria tarefa e função. É neste quadro de referência, caracterizado pela comparação e às vezes pela confrontação direta, que devemos interpretar muitas das trocas entre pais e trabalhadores de creche. Existem medos, às vezes desconhecidos ou não explicitados, que deveriam ser detectados e entendidos para que estratégias adequadas sejam implementadas. Por exemplo, o medo que sentimos das opiniões dos outros às vezes é um sentimento forte, que marca as etapas iniciais do relacionamento, quando algumas coisas não são ditas para agradar o outro. Outro sentimento comum é o medo de perder poder ou status. Os pais estão autorizados, por seu status natural, a decidir por suas crianças, mas devem sempre mostrar que são bons pais. Os trabalhadores da creche podem sentir que sua posição como pessoas habilitadas e competentes está ameaçada: a capacidade e a qualidade de "especialistas" que os pais enxergam neles pode então ser questionada, se os educadores não puderem identificar ou responder às demandas dos pais ou necessidades específicas das crianças."

Assim, quando se trata da dimensão do cuidar a família, questiono:

Em que medida o conhecimento acumulado na creche está dando conta de preparar melhor as famílias para viver a situação de ter filho na creche, de usar a creche como um serviço, conhecer as vantagens e desvantagens, entender as dificuldades e trabalhar na perspectiva de superar essas dificuldades?

\section{- Medidas para favorecer a interação entre a creche e a família}

As coordenadoras relataram algumas ações que favorecem a interação entre a creche e a família.

Partindo do reconhecimento das dificuldades da família para separar-se da criança e deixá-la na creche, a equipe propõe-se a atender a família ajudando-a a lidar com tais dificuldades, transmitindo segurança. A idéia da segurança relaciona-se à confirmação de que os pais serão chamados caso a criança não fique bem.

A separação, deixar a criança, é um momento difícil, tanto para a creche quanto para as famílias. Por isso a gente tem que cuidar dos dois, da 
criança e da família também. Os pais ficam super preocupados, acham que nunca vai solucionar, e a gente sempre procura passar segurança, "Você vai? Você está bem? Então vá tranqüilo, fique tranqüilo que nós chamamos de volta, se precisar". Mas é muito difícil mesmo, não é um momento fácil.

A exposição da coordenadora quando ela diz "os pais acham que nunca vai solucionar" evidencia uma interpretação de que a preocupação dos pais limita-se ao sofrimento da criança. Conforme citamos anteriormente, há outros receios e anseios vividos por eles na experiência de ter um filho na creche. Assim como para com a criança, é preciso ser empático, isto é, reconhecer as necessidades da família, segundo o significado que tem, para eles, essa experiência.

No que se refere a atender a necessidade dos pais de ver que a criança está bem na creche, verifica-se que as equipes vão buscando soluções criativas, antecipando respostas às dúvidas e angústias, particularmente no que se refere ao impacto da inserção na creche para a criança. Assim, cuidam, acolhendo bem crianças e famílias, construindo uma nova concepção de creche, como um bom lugar para a criança estar.

A gente viu que era tão difícil para os pais, que a gente montou um trabalho. A gente gravou as entrevistas com as famílias, depois a entrada das crianças, logo no início, depois de uma a duas semanas que a criança ainda precisava muito, não conseguia dormir, não conseguia relaxar; sem a família, como a criança respondia; e um mês depois, como ela estava bem, entrando na rotina, já era tranqüilo para ela entrar na sala de sono, dormir, comer. Foi super legal, a gente mostrou esse vídeo para os pais.

Eu acredito que para a criança vir para essa creche hoje, que é uma creche que sabe acolher, é muito bom. É muito bom para a família, a mãe vai trabalhar tranquiila, sem culpa. A creche inclusive pode ajudar nesse processo de estar tranqüila, de receber como um bom lugar para a criança ficar e não como a falta de opção. A gente saber dizer isso para as famílias, está construindo isso junto.

Mantovani e Terzi (1998) descrevem e fundamentam as intervenções que preconizam para a inserção da criança na creche. O primeiro destaque é como, consistentemente, atender as necessidades da criança e da mãe/pai, a fim de "construir uma colaboração real e não só declarada, um relacionamento de confiança baseada em conhecimento direto daquilo que fazemos". A estratégia do vídeo, relatada pela coordenadora, vem ao encontro de um dos requisitos para o relacionamento de confiança. Conforme Mantovani e Terzi 
(1998), "Fornecer conhecimentos precisos e antecipados das intervenções que se realizarão, explicando seus motivos, levar os pais a não se submeterem passivamente, mas a compartilhar e controlar a inserção, ajuda-os a "conter" uma ansiedade que poderia ser transferida para a criança, gerando nela também insegurança e desconforto".

Inclui-se entre as medidas para resolver impasses entre a família e a equipe, a intervenção de um profissional especializado da equipe técnica ou da coordenação central.

Quando a coisa está pegando mesmo, está difícil, eu chamo a T., porque ela tem a técnica para ponderar.

No discurso seguinte evidencia-se uma compreensão bastante realista sobre o trabalho e as relações da creche com a família, bem como se explicita uma estratégia de intervenção efetiva para a melhoria das relações entre a creche e a família, realizada pela coordenadora junto às educadoras: refletir sobre as idéias e sentimentos em relação à família.

A gente vai tentando mostrar essa contradição na prática, para que as pessoas se dêem conta disso e tentem trabalhar de uma maneira diferente. Pelo menos incluam todas as rivalidades com a família como dados do trabalho.

Conforme já apontado anteriormente, o papel da equipe técnica revelase amplo e complexo. Saitta (1998) escreve que o coordenador pedagógico deve ter competências relativas à organização do serviço, ao projeto educacional e às competências profissionais dos educadores. Dentre as competências profissionais dos educadores, cita os confrontos entre pais e educadores. Dessa feita, os profissionais da equipe técnica precisam desenvolver:

1) "Capacidade de análise para manter o grupo na elaboração do projeto pedagógico

2) Capacidade de organizar os meios de ação mais eficazes, para permitir que o grupo alcance os objetivos pré-estabelecidos

3) Capacidade de síntese que ajude o grupo a assumir e levar a termo as tarefas assumidas

4) Capacidade de comunicar, para permitir a si mesmo e aos outros as trocas dos significados das próprias experiências" (Saitta, 1998). 


\section{PARA AS EDUCADORAS}

Quanta dificuldade tem no relacionamento da família com a creche.

No discurso das educadoras o relacionamento entre a creche e a família é apresentado como difícil por um rol de contendas que foram abordadas durante as reuniões e são descritas aqui como expectativas, percepções, sentimentos $\mathrm{e}$ ações relacionados às interações entre a equipe da creche e a família. Ao mesmo tempo, foram transmitidos exemplos de medidas para apoiar os pais. Esse relacionamento assume características ímpares quando a mãe-usuária é trabalhadora da creche.

\section{- Expectativas, percepções, sentimentos e ações relacionados às interações entre a equipe da creche e a família}

No discurso das educadoras, apreende-se que a relação entre creche e família é inevitável e, se não for bem cuidada, pode estabelecer-se uma disputa a respeito de quem é a melhor pessoa para assegurar um crescimento saudável para a criança.

Há comportamentos da família para com a criança que divergem dos desejados pelas educadoras. Algumas vezes, a forma das mães lidarem com o difícil momento da separação é tentar aproveitar a distração da criança e sair sem avisar. Isso gera uma dificuldade para as educadoras, pois elas sabem que essa maneira não é apropriada, não atende as necessidades da criança, e pode causar-lhe ainda maior insegurança. Atribuem esta ação à incompreensão da mãe sobre a situação.

Tem situações que a criança está brincando com algum objeto e aí a mãe quer aproveitar essa oportunidade e fala: "agora eu vou”. Não entende. Não passa uma relação de confiança prá criança. Independente da faixa etária, ela quer aproveitar.

Num extremo oposto, algumas vezes, a preocupação do pai com uma exigência externa de trabalho é maior, então ele deixa a criança chorando e vai embora, deixando o problema nas mãos da educadora.

Tem dias que o pai está tão apressado que ele quer ir embora logo, talvez porque levou uma da chefe, e ele sai e deixa a criança chorando. E a gente tem que segurar a barra, levar a criança para ver a tartaruga, o peixe. 
Devido a sentimentos de culpa, os pais têm dificuldades para colocar limites à criança.

Os pais se sentem culpados e acabam fazendo uma troca, uma chantagem material. Vem todo dia com aquela surpresa, sabe? Todo dia a criança quer uma coisa.

Outra forma inadequada de lidar com a questão dos limites é quando os pais fazem chantagem com a criança, dizendo que não a deixarão ir para a creche.

A creche, por mais que o pai não entenda a questão da educação infantil, ele sabe que ali é um lugar gostoso para o filho dele, e ele faz uma chantagem "Você não vai à creche. Castigo". Porque eles sabem que ali é um lugar bom, que o filho gosta. A maneira que ele tenta corrigir o filho é não deixando ele desfrutar de uma coisa gostosa. Que é o único passeio que essas crianças fazem também, é ir prá creche, a gente percebe muito isso.

Quando não manifestam dificuldades em deixar a criança na creche, as educadoras entendem que os pais são despreocupados, não se importam muito ou consideram natural deixar a criança na creche.

Ele não liga muito, é um pai meio desligado, ele acha que a mãe tem que trabalhar, ele deixa lá. Ele não tem assim essa preocupação, do local, já aceita como uma coisa natural.

Para as educadoras, os pais têm deixado muita responsabilidade para a escola porque não sabem o que compete a eles na educação da criança.

Os pais não conseguem saber qual é a bagagem que eles têm que dar para a criança. Começam a delegar muita coisa para a escola e isso não ajuda a criança, deixa uma lacuna, que é a contribuição do dia-a-dia do pai.

Ao reclamarem desses comportamentos, as educadoras estão manifestando, implicitamente, suas expectativas em relação aos pais. Ademais destas, esperam que a família esteja comprometida com o conteúdo que a creche quer ensinar, pois, se a família se compromete com o conteúdo, a criança aprende melhor.

A gente necessita de compromisso da família com o conteúdo que a creche está querendo passar. Se tiver esse comprometimento, todo conteúdo que a escola traz é absorvido pela criança, ele é aproveitado na sua mente, porque ele é valorizado. Aí o produto é um indivíduo crítico, que a gente traz o conteúdo... Se esforça para transformar este indivíduo crítico, autônomo, independente. 
Essa expectativa decorre de uma concepção de que a integração entre a família e a escola é a base da educação, particularmente a educação infantil.

Eu não consigo ver educação, seja a educação infantil, educação fundamental ou média, sem ter um comprometimento família e escola. A educação da criança vem de um casamento entre família e escola, e principalmente nos primórdios, que é a educação infantil.

Entretanto, coloca-se aqui um conflito: não se sabe o que compete à escola e o que compete à família, na educação.

Em qualquer política educacional que o país tenha atravessado, a gente tem uma dissociação muito grande família e escola. Nem a família nem o Estado conseguem falar o que é responsabilidade de $x$ o que é responsabilidade de $y$.

Vale destacar que as educadoras também referiram não saber afirmar os limites de suas funções junto às crianças.

A exemplo da experiência italiana descrita por Bonomi (1998), ressaltase nos discursos das educadoras recriminações aos pais. Estas se "queixam de uma série de comportamentos e atitudes que consideram inadequados em relação às crianças e desrespeitosos em relação a elas mesmas". É conveniente destacar que o autor elucida que tais recriminações "apresentamse idênticas, salvo algumas exceções, em creches que possuem histórias e percursos diversos, sinal de uma dificuldade geral, somente em parte imputável a contingências particulares".

Bonomi (1998) discorre sobre vários exemplos de críticas aos pais, muitas das quais também foram referidas pelas participantes deste estudo. Estas referem-se à: 1) transgressão de regras da creche, como horário de entrada e envio de roupas e pertences pessoais; 2) comportamentos inadequados dos pais, seja para com a criança seja para com a educadora - de manhã, estão sempre com pressa e vão embora sem se despedir da criança; são indecisos para ir embora levando a criança a chorar; têm a pretensão de encontrar sempre a mesma educadora e têm algumas preferências; não confiam quando the dizem que a criança para de chorar assim que eles saem; quando vêm buscar a criança, somente perguntam se comeu e dormiu, não se interessando por mais nada; ficam conversando por muito tempo sobre coisas sem importância e criam confusão; se a criança criar algum problema ou fizer 
algo que não deve, eles não interferem. 3) têm comportamentos educacionais errôneos, que fazem com que a criança adquira maus hábitos que, depois, devem ser corrigidos e administrados pelas educadoras.

\section{Para Bonomi (1998)}

"De certa maneira, é lógico esperar que se ocupar da mesma criança, a partir de posições e contextos tão diferentes como a família e a creche, faz com que surjam dificuldades e conflitos. Com freqüência, leva muito tempo para encontrarem uma solução e os conflitos tornam-se crônicos, até criar-se, entre educadoras e pais, um clima relacional bloqueado, no qual parece impossível que de alguma parte surjam iniciativas ou sejam acionados procedimentos voltados a uma efetiva superação do conflito".

As manifestações de sentimentos e conflitos maternos/familiares provocam desconforto nas educadoras, porque, muitas vezes, elas não sabem como lidar com essas questões.

Um exemplo corriqueiro é o ciúme da mãe em relação à educadora, quando a criança demonstra gostar muito desta:

Eu fico incomodada um pouco, porque você não sabe o que responder, quando a mãe fala "mas ele gosta tanto de você". Porque ela não conta "que bom que ele gosta de você", ela está mostrando "nossa, mas ele gosta mais de você do que de mim". Teve criança que chamava a mãe pelo nome e chamava a educadora por mãe. E a mãe tinha um sentimento muito difícil "por que ele te chama de mãe e não me chama de mãe?" Como a gente estaria falando com essa mãe? A gente tenta entender a mãe, mas, muitas vezes, a gente tem dificuldade em como expressar prá ela "esse é o processo mesmo, essa é a relação que ele primeiro está construindo, depois ele vai identificar a gente como a educadora, e a mãe é uma outra coisa. No final da tarde é ela que ele quer encontrar".

Quando a mãe demonstra dificuldade de separar-se da criança, elas não sabem como agir.

O quanto [a educadora] consegue dizer isso prá mãe. Olha, quando você conseguir [sair] você me procura, que eu estou aqui, e as outras educadoras. Quando você quiser ir embora eu pego a C. pode ir tranquiila. A gente fica andando, uma sombra atrás da mãe prá pegar a criança, cercando a mãe e a criança, até a hora que a mãe consegue entregar.

É difícil prá mãe ir embora e deixar a criança chorando. A gente fala, vai lá na frente, fica lá na frente uns dez minutos, ela vai parar. A gente vai lá e fala "pode ir embora que ela está legal".

Tem mãe que fica o dia inteiro lá fora. 
Algumas manifestações de sentimentos maternos em relação a deixar a criança na creche demonstram ambigüidade. Isto leva as educadoras a sentirem-se desnorteadas.

Essa semana aconteceu, a mãe saiu e a criança chorou, chorou, chorou, não queria saber, chorou, chorou, chorou, acho que não queria ficar na creche. E ela saiu acabada. No outro dia, aconteceu ao contrário, a criança queria ficar e ela saiu [e falou] "eu fiquei desmontada porque hoje ela não chorou".

É curioso notar que uma educadora reconhece, em sua própria experiência, a necessidade de, como mãe, certificar-se que a criança está feliz na creche: não é o outro que diz sobre isso, ela está vendo. Mas parece que elas não reconhecem essa mesma necessidade nas outras mães, ou, reconhecem no discurso, mas não sabem como lidar com os comportamentos associados a ela.

Falando como mãe, quando a gente chega no módulo e vê que a criança está se divertindo, está brincando, é uma reação tão estranha, de você não querer que ela te veja prá poder observar aquela alegria dela ali, que as educadoras estão podendo passar prá ela. É muito legal, ver o sorriso dela e falar fulana é educadora dela.

As educadoras interpretam que os pais sofrem com incidentes que ocorrem na creche, bem como com riscos potenciais da convivência com outras crianças no ambiente coletivo.

É difícil prá esses pais viverem o coletivo da creche, de ver que a criança caiu, bateu, mordeu, é difícil prá eles agüentarem esse coletivo...

Tem um que está com o olhinho vermelho, então é melhor não levar, porque ela pode complicar, com conjuntivite. Nem sabe o que o outro tem, mas só de entrar e ver, já acha que a filha dela vai pegar.

Também são motivos de insegurança e sofrimento para os pais: deparar-se com uma educadora desconhecida, o choro da criança, uma experiência anterior desagradável. As educadoras se sentem mal com as manifestações desses sentimentos, pois consideram que a insegurança é sinal de falta de confiança no trabalho delas.

A referência que a mãe tinha era da M., e a S. ali era uma estranha, mesmo ela fazendo parte do grupo [a mãe pergunta] "você é daqui, você é nova?".

A gente passa isso quase todos os dias. Na situação de não encontrar a educadora, a criança às vezes já fica numa boa com você, mas os pais não... Aí você conversa. E a gente se sente mal porque a gente fica todo dia com as crianças, a gente tem um convívio maior com as crianças e os pais 
ainda ficam meio assim... Até passar essa tranqüilidade para os pais, que você está ali prá trabalhar e que você é tão competente quanto a pessoa que está ausente, que eles confiam. É constrangedor.

Ainda, cogitam que eles podem ter dúvidas sobre o que acontece realmente na creche, o que é feito com as crianças atrás dos olhos da família.

A mãe entregando a criança para o educador, como às vezes é fácil e às vezes é difícil. Muitas vezes, é difícil porque ela não conhece o trabalho. Por exemplo, eu tenho as minhas crianças na creche e conheço o trabalho das meninas e, às vezes, eu também tenho dificuldade de passar as minhas filhas, porque a gente não sabe como está sendo lá dentro. Eu penso: eu tenho essa dificuldade e o outro que está lá no $\mathrm{HU}$, ou não sei aonde? Como é complicado isso.

A mãe fala "ele não comeu ou ele comeu?". Parece que ela desconfia do nosso trabalho. A gente já passou por fases que você fala "ele está bem", mas a mãe não consegue se certificar de que ele está bem, porque ela tem uma insegurança muito grande. E acaba causando na gente também, às vezes, uma insegurança, porque é uma situação delicada se você não conseguir uma cumplicidade com a mãe.

Consoante as educadoras, outra justificativa para tais comportamentos dos pais é que algumas dessas razões são desculpas utilizadas para atenuar um conflito que está no inconsciente deles.

Acho que os pais usam isso inconscientemente, uma coisinha com a criança, ou até mesmo uma mordida que aconteceu um dia antes. "Ela já foi mordida hoje, então amanhã você não leva".

Elas conseguem identificar sentimento de culpa patente em certas conversas das mães com as crianças.

A gente tem que estar controlada, tranqüila, para poder lidar com a mãe $e$ com a criança. Tem mãe que fala "a mamãe vai te deixar aqui na creche, não briga com a mamãe", pedindo desculpa. Isso acontece, o sentimento de culpa da mãe estar deixando lá, não poder ficar com ele.

Incomoda-as ouvir que as educadoras que são mães sabem cuidar melhor das crianças.

E quando a mãe acha que, se você é mãe, você sabe cuidar do filho dela, já tem a experiência de mãe para passar para o filho dela. Diferente de outras educadoras, que são solteiras, têm uma aparência mais jovem...

A imagem de que mães são mais competentes como educadoras é um mito, de que basta ser mãe para saber cuidar de uma criança. E exprime uma representação inserida na "problemática do substituto materno: na falta de 
cuidados maternos há necessidade de cuidados do mesmo tipo, dispensados por uma figura que seja a imagem da mãe" (Spaggiari, 1998).

Pode-se constatar que esse modo de conceber a atenção na creche é percebido pelas educadoras como uma desvalorização de seu trabalho. Elas desejam ser reconhecidas como educadoras, com competência profissional e não como portadoras de experiência de maternidade. Assim, é um ponto de conflito das educadoras com os pais a visão de que o trabalho que elas realizam não corresponde à concepção de educadora ou professora.

Os pais não têm clareza do nosso papel na educação infantil. Por mais que a gente faça, como professor, porque a maioria o é, nós não somos uma escola. E, para os pais, não é um depósito de crianças, mas não é uma escola. A gente tem que fazer essa discussão, porque a gente está buscando valorização, como educador, e para os pais entenderem educação infantil.

Fica mesmo ou é crecheira ou é ainda a babá. Nós estamos sendo valorizadas, mas ainda não tem essa discussão, não tem clareza do nosso papel, da importância da educação infantil, porque é a base de tudo...

Sentem-se desrespeitadas, pois alguns pais desdenham delas.

Geralmente são pais desse tipo, que mal olham prá sua cara. São poucos, mas têm aquele olhar... De arrogância.

Como se você fosse uma empregada dele, uma babá, ele não paga nada....

São alguns pais, pequena minoria. Mas que incomoda, incomoda.

Não pode se dizer que é de classe social. Pelo contrário, tem pai educado, que tem uma visão bem clara do cumprimentar quando chega, dizer até logo, até amanhã, quando sai. Não é uma classe menos favorecida.

Identificam como mais um indicador de que os pais não as vêem como profissionais competentes quando eles se surpreendem ao saber que muitas das educadoras fizeram faculdade.

A gente comenta "eu fiz faculdade", os pais fazem uma cara de espanto. "Você tem faculdade?" Eu falo "eu tenho, a R. tem, a M. tem, a S. é psicóloga a I. é socióloga. [E eles] "você viu, bem? Elas têm faculdade". Parece que descobriram a América, que realmente são pessoas que sabem, são profissionais que têm um nível superior, realmente elas sabem o que estão fazendo, elas estudaram.

É provável que essas manifestações dos pais decorram de sua representação sobre a pessoa que cuida: mulheres, cujo trabalho tem pouco valor, que não precisam formação. Emiliani e Molinari (1998) relatam que, nas 
pesquisas sobre creche, as características das educadoras mais apreciadas pelos pais deixam emergir uma

"representação do pessoal como "moças" dotadas de características individuais particularmente adequadas ao trabalho que fazem (grande paciência, doçura, amor pelas crianças, atitudes maternais). A imagem das educadoras é mais direcionada a colher e apreciar os dotes individuais que à preparação profissional. Os conteúdos dessa preparação não são conhecidos pelos pais e, de qualquer modo, não são determinantes para a capacidade das educadoras de instaurar relações positivas com as crianças".

Ademais, provocam uma interrogação:

Em que medida tais manifestações podem ser decorrentes de uma apresentação precária da equipe e do trabalho?

$E$, finalmente, as escolhas dos pais acerca de a quem dirigir demandas específicas dentre os membros da equipe da creche podem ser facilitadoras ou não das relações.

Aquele pai que tem um pouco mais de consciência do papel da educação e da instituição e de como ela funciona ele se reporta muito mais vezes a esse staff. Ele sabe em que a psicóloga vai ajudar, qual é o papel da pedagoga ajudar, ele sabe a quem se reportar diretamente, e o pai que não tem essa clareza, ele acaba chamando nós mesmas.

Algumas vezes, as educadoras sentem que os pais confiam mais nas coordenadoras, porque demandam a elas também quando o problema não justifica uma intervenção destas.

É uma outra relação. Porque além da educadora, tem alguém superior que mantém uma outra tarefa, uma outra responsabilidade, que reforça o cuidado. Saber que existe um outro nível que está cuidando daquilo, fica muito mais forte.

Essa posição é bem valorizada. Tem pais que não falam prá gente no final da tarde, e vão conversar com alguém da coordenação. É um aspecto negativo, porque a confiança ainda fica num poder hierárquico. A gente sente muito isso, que os pais pegam a criança no final da tarde, muitas vezes não falam com você. Na verdade é um cargo meio hierárquico, elas mandam e as outras obedecem.

Da parte das educadoras, também há expectativas, percepções, sentimentos e comportamentos que podem dificultar o desenvolvimento de uma relação mais profunda. 
Por exemplo, não seguir uma rotina, por respeito a uma dificuldade do pai, não é relatado como um exemplo de flexibilidade para estar atendendo ao pai, mas sim como estar "abrindo uma concessão".

Tem um pai que não troca [a fralda da criança] de jeito nenhum. Ele tem consciência de estar agindo mal. Porque a gente fala: "mas é tão importante você estar com a criança nesse momento porque, trocando, você está próximo, vai conversando com ele. É fedido? É fedido. É ruim? É ruim. Mas é o que ele tem prá oferecer e ele quer que você limpe". E o pai "eu sei, mas não dá não". Quando o pai ou a mãe chega, a responsabilidade é deles, porque a criança não quer mais a gente. Não dá nem prá querer competir com o pai e com a mãe. E como ele tem essa dificuldade, se justifica, a gente fala "tudo bem M.", mas a gente deixa bem claro que está abrindo uma concessão porque aquele momento é dele e do filho.

Emiliani e Molinari (1998) localizaram, em investigações sobre situações de creche, resultados que falam sobre ansiedades, medos e expectativas dos pais. Relatam que uma das dimensões encontradas "foi definida como flexibilidade da Instituição e expressa a solicitação de uma creche que se adapte às exigências de cada criança e de sua família". Pensar uma ação diferente como uma concessão, é o mesmo que pensar estar prestando um favor, ou seja, fora do âmbito da flexibilidade. Se não há flexibilidade, não há cuidado.

Entendendo que a atuação de outros profissionais ajuda nas dificuldades com a família, solicitam que a creche ofereça cursos e palestras para os pais.

A gente pede muito que tragam palestrantes para falar com os pais. Quando o Yves falou sobre os limites, foi extremamente importante para os pais porque alguns já conseguem se desprender melhor. Por mais que a gente fale, e eu vejo isso em todos os pais, o profissional tem essa arma de estar falando, tem um outro peso e a gente entende que isso é importante. É a coisa do psicólogo também. Tem hora que fica difícil a gente lidar com algumas mães, então aí entra a $R$. Divide um pouco essa tarefa.

Se, por um lado, as educadoras sentem-se menosprezadas quando os pais recorrem às coordenadoras para resolver questões que elas poderiam resolver, por outro, elas reforçam figuras de autoridade, também, quando depositam nos especialistas, os palestrantes, a expectativa de resolver contendas com as famílias. Outro ângulo referente ao anseio da vinda de palestrantes revela-se como a idéia de que os pais precisam aprender sobre a educação infantil. De maneira semelhante, percebem que elas também podem contribuir para a instrução dos pais. 
Outro dia uma mãe estava questionando a coisa do falar "o fulano fala errado e a mãe em vez corrigir..." [a educadora respondeu] "a gente não trabalha mesmo dessa forma. Ao invés de recriminar, a gente diz a palavra correta e a criança já vai perceber. Por exemplo, a aga, você quer água? Então ele já vai assimilando isso". Eu pensei o quanto a gente está instruindo esses pais. Não precisa do autoritarismo o tempo todo.

É meritória a preocupação da educadora em compartilhar com os pais a visão da creche. Entretanto, a imagem que se conforma aqui é a dos pais que se beneficiam do saber da creche, porque eles não sabem muitas coisas. $\mathrm{Na}$ verdade, o saber dos pais pode ter outros fundamentos, diferentes do saber da creche. E, quando isso não é considerado, está se incutindo um valor menor à cultura da família.

Segundo Cipollone (1998),

"O saber familiar é dificilmente comunicável, mesmo no seu interior, é um saber nascido na prática, não sistemático, emotivamente conotado, em relação ao qual o saber das educadoras se propõe com características bem semelhantes, seja pela falta da específica preparação profissional, seja pelo fato de ser o próprio pessoal da creche, na maior parte, constituído por mulheres, ele próprio frente ao problema de redefinir o seu papel materno".

Ademais, para que os pais, como se dá com qualquer pessoa, assimilem um novo conceito, uma nova visão, é necessário que essa nova visão faça sentido para eles. Se não discutimos o que fundamenta uma determinada ação para com a criança, é possível que eles continuem acreditando que o seu modo de agir é o melhor.

Os conflitos nas relações entre a creche e a família não são privilégio da cultura brasileira. Segundo Bonomi (1998), as educadoras italianas manifestam dificuldades na administração de relacionamentos complexos como os de educador-criança-pai. Por outro lado, elas conseguem explicitar melhor suas competências didático-educacionais, o que é explicado pelo autor como decorrência de uma imagem consciente do próprio profissionalismo mais estreitamente vinculada a essas competências. De maneira semelhante, as educadoras deste estudo também explicitam e justificam com maior propriedade as ações que realizam junto às crianças. 


\section{- Medidas para favorecer a interação entre a creche e a família}

Apesar desses desencontros, as educadoras acreditam que, com respeito mútuo, é possível a creche e a família caminharem juntos no atendimento da criança.

A gente faz um pedaço, mas quem é casado e tem filhos sabe que a outra parte é da mãe, é da família e não tem como a gente estar se intrometendo, entrar nesse campo. Como eles também têm que respeitar nosso trabalho. Por isso a gente tem que caminhar juntos, prá poder chegar em algum lugar.

Para isso, entendem que a boa interação com as mães é primordial. É interessante assinalar que, embora não desejem ser consideradas melhores ou piores educadoras pelo fato de serem ou não mães, nos discursos a seguir, aparece a premissa de que o fato de ser mãe favorece que a educadora compreenda melhor as outras mães.

É bem importante prá gente que é mãe confiar mesmo na educadora.

Se você não conseguir essa cumplicidade com a mãe, o trabalho vai ficar meio truncado, porque, automaticamente, a criança também vem contagiada com aquele sentimento. E, falando como mãe, é tão mais fácil entregar o seu filho quando você tem essa relação boa, essa cumplicidade. Como mãe você consegue entender um pouco aquela mãe e aquela criança que está entrando.

Percebe-se aqui como as educadoras imputam às mães toda responsabilidade pelo cuidado da criança no domicílio.

Para criar uma boa relação com as mães, o primeiro passo é tranqüilizálas durante o período de adaptação. Para isso, garantem formas de manter 0 contato e transmitir informações sobre a criança.

A mãe pode ir que a gente liga. Ou, se a mãe está muito ansiosa, ela pode ligar ou avisar e dar uma passadinha na hora do almoço e ver que está dormindo, olha tudo, vê que está brincando...

Todavia, não basta preocupar-se com as mães no período de adaptação. Durante todo o tempo em que a criança freqüenta a creche, há fatos que podem abalar a confiança materna, o que estabelece a necessidade de preservar as boas relações continuamente.

Tem mãe que conhece a gente, que tem filho que veio para o berçário e que hoje está no G2. Mas a gente tem que reconstruir todo dia aquele vínculo de confiança porque é só a criança aparecer com uma mordida... Desmorona. 
Visando aproximar a creche e a família, foram estruturadas atividades que favorecem as relações entre as duas instituições.

Na instituição, parece que já tem a preocupação de dar tranqüilidade para a família e criar esse elo família-creche, creche-família. Tem projetos que a família pode vir passar um dia com a criança, ou da criança levar prá casa um objeto da creche, não só trazer, ela também pode levar. A gente faz oficinas, a família pode ficar com a criança aquele dia, irmão, primo, tio, quer dizer, é um lugar gostoso.

Mesmo entendendo como sua função ajudar os pais a superar suas inseguranças, nem sempre a educadora tem sucesso nessa missão, terminando por encaminhá-los à equipe técnica, no caso, a psicóloga.

É do papel mesmo, você estar conversando com os pais, para ver se acaba ajudando. O pai está inseguro, apesar de tudo que a gente fala, ele acha que nós não somos competentes e que a criança não vai ficar bem. Então a gente passa a bola para a psicóloga.

A preocupação em ajudar os pais a superarem suas dificuldades mostra uma atenção e disponibilidade das educadoras de tal forma que alguns pais adquirem tamanha confiança nelas que começam a compartilhar questões íntimas, conflitos familiares.

Na creche saúde, você acaba até sabendo demais às vezes da família, e se envolve emocionalmente, por conta da creche ser pequena. É uma facilidade o espaço com menos crianças, é um fator importante para a interação. E facilidade é a interação que se dá entre o educador entre a família, entre as crianças, a troca de informação.

Às vezes, a confiança que os pais têm na gente ultrapassa o nosso conhecimento. Por exemplo, tem pais que chegam e começam a descrever situações da vida familiar que não competem a nós... Ultrapassa a confiança, entra numa questão de intimidade, de desabafo.

As relações entre a creche e a família adquirem caraterísticas singulares quando a mãe é educadora e tem um filho seu freqüentando a creche.

Como uma das dificuldades foi citada a interferência na rotina do trabalho porque a criança solicita a mãe quando a vê. Este problema é resolvido quando se evita que a criança esteja constantemente visualizando a mãe.

A criança te vê todo momento e você tenta ser o mais profissional possível. Só que a criança quer a mãe sempre. Muitas pessoas não entendem isso. Os outros educadores cobram de você a posição de educador. A gente quer ser mãe, a gente quer ser educadora, mas é complicado no mesmo 
ambiente. Depois que eu fui para a Central, ela ficou mais tranqüila, eu me senti mais tranqüila, consegui trabalhar melhor e eu sinto confiança no educador de saber que ela está bem. E para o educador é bom, espaço só da criança, espaço do educador.

É também uma dificuldade para as relações a exigência do trabalho que não thes permite usufruir os mesmos direitos que devem garantir às demais usuárias: as educadoras não dispõem da possibilidade de se afastarem do trabalho para realizar a adaptação de seus filhos, pois são dispensadas apenas por um dia para isso. Houve um debate intenso e veemente no grupo a esse respeito.

A gente sofre outra pressão. Nós não temos os mesmos direitos que as mães com quem a gente lida. Uma mãe fica uma semana fazendo adaptação e nós temos um dia para fazer a adaptação. Ou então nós temos que trazer outra pessoa para fazer o resto dos dias que precisa. Todo mundo que passa por essa fase sente muito isso... É um sentimento que também permeia nossas relações. É difícil às vezes conseguir digerir. Porque você, por ser parte da instituição, é muito diferente daquele que você presta o serviço para ele.

Tal como as mães que não são educadoras, elas também se sentem ansiosas, têm dúvidas e receios sobre o atendimento que será oferecido aos filhos na creche.

As minhas filhas estão na creche Central. No começo, eu fiquei meio preocupada porque era outro ambiente, são outras pessoas. Eu não tive tanta preocupação com a primeira, porque ela é maior. Quando a C. começou a ir, eи achei que fosse desmontar, fiquei muito angustiada, pensando: será que elas vão colocar travesseiro atrás da cabecinha da menina, será que vão lavar aquele brinquedo que caiu?

É, de certa forma, surpreendente, que as educadoras sintam-se tão desconfortáveis com as manifestações de insegurança das mães, sendo que elas próprias sentem-se inseguras em relação ao atendimento que as colegas dispensam a seus filhos. Uma forma de lidar com essa insegurança, é garantir que o filho fique na mesma creche onde trabalham.

Eu também não quis que [os filhos] fossem [para outra creche], porque eu pensei: é longe, se tiver alguma coisa até eu sair daqui, chegar lá...

Eu quero que meu filho fique aqui, porque eu estou perto qualquer coisa que acontece. Se ele estivesse lá, só depois de uma hora que eu ia saber alguma coisa em relação a meu filho.

Reiteradamente, surgem as ambivalências entre os papéis de mãe e trabalhadora: como trabalhadora conhece o serviço e reconhece sua qualidade, 
mas, como mãe, quer o filho sob sua vigilância. Ao mesmo tempo, quando a mãe usuária se comporta tal como ela, entende isso como falta de confiança no serviço.

O processo de construção do vínculo de confiança segue o mesmo caminho que acontece com as outras mães. É nas ações concretas das companheiras que a mãe-educadora desenvolve confiança.

Com o passar dos dias, a educadora me passou uma tranqüilidade muito grande e teve um dia que eu até me surpreendi com ela, porque já tinha passado do horário de ir embora, e ela estava me esperando para falar como tinha sido a manhã da C. Foi muito bom, porque nunca aconteceu isso lá na outra creche, de uma pessoa ficar me esperando para contar.

Novamente, declaram que confiam porque conhecem o trabalho.

A gente que é do módulo 1 e que já foi do berçário, é mais fácil a gente confiar. Conhece como é lá dentro.

Você conhece o trabalho das educadoras e sabe que todo mundo procura dar o melhor.

A oportunidade de estar no papel da mãe, nessa relação entre a creche e a família, poderia permitir à educadora a possibilidade de compreender melhor a situação e as dificuldades das mães usuárias da creche. Mas esse processo não é automático. Seria de grande valor utilizar essas experiências para uma reflexão sobre o significado da experiência de ter um filho na creche para as mães. 
Ao que tudo indica, o estudo em tela cumpriu o objetivo de apreender e analisar as representações sociais das coordenadoras e das educadoras das creches integrantes do mesmo acerca do cuidado à criança. Os dados mostram que é possível identificar convergências e divergências entre as representações de ambos os grupos, ressaltando-se que cuidar é sempre imperativo.

Para as coordenadoras:

- cuidar é responsabilizar-se pelas crianças

- as crianças precisam ser cuidadas e para cuidar, o ambiente necessita ser organizado de um modo específico.

- o cuidado abrange duas grandes dimensões: o atendimento das necessidades da criança, da mãe e da família; o estabelecimento de relações pessoais baseadas em sensibilidade, aconchego, conforto, manifestações afetivas, além de flexibilização das normas de funcionamento institucional.

- os pólos educação e cuidado são verbalizados como tendo igual valor, porém tanto o discurso como o cotidiano revelam que a relação entre eles não é paritária. Enquanto a educação tem um valor próprio, a valorização do cuidado só se dá porque possibilita ações pedagógicas.

- a dita valorização do cuidado não é proporcionalmente acompanhada da expressão de idéias e conceitos, nem mesmo de relatos de situações e exemplos de cuidados.

Para as educadoras:

- cuidar é estar atenta o tempo inteiro.

- a criança precisa ser cuidada para sentir-se bem e estar disponível para o aprendizado e nisso reside a importância do cuidado. O cuidado é, portanto, um requisito para a aprendizagem.

- cuidar também é organizar o ambiente e atender necessidades tais como: alimentar, higienizar, permitir o descanso e manter a segurança.

- as crianças pequenas demandam mais cuidados que as maiores. 
Não é demasiado destacar que, para esse grupo, muitas atividades relativas ao cuidado não são nominadas como tal, permanecendo sob esse espectro apenas as relativas a higiene, repouso, alimentação e segurança.

Para ambos os grupos, o cuidado institucional é diferente do cuidado prestado pela família e há um reconhecimento das dificuldades em oferecer 0 cuidado necessitado pela família.

A determinação última de tais representações parece residir na concepção da função social da mulher muito mais aderente ao senso comum que a coloca como naturalmente capacitada e habilitada a prestar cuidados pela essência feminina que carrega, embora racionalmente tanto coordenadoras como educadoras acreditem que estejam realizando atividades de competência profissional, embasadas cientificamente.

Contrapõe-se a tal visão a concepção das funções das mulheres como historicamente determinadas, em que cuidar aparece como resultado de uma dada organização social que dicotomiza os mundos público e privado, colocando nesse último o fazer das mulheres voltado para a reprodução social na dimensão não só da reprodução da força de trabalho (biologicamente determinada) mas o cuidado desta visando sua inserção social produtiva. Isso se dá por meio do trabalho das mulheres cuidando de si mesmas, dos filhos, dos companheiros, do restante da família, contraditoriamente composto de atividades naturalizadamente femininas e não como trabalho, portanto, desvestido de valor social.

Tal concepção aparece claramente nas falas das educadoras ao recusarem-se a nominar de cuidado muitas das atividades desenvolvidas junto às crianças. Quanto às coordenadoras, as concepções acerca do cuidar aparentemente revelam conteúdos mais reflexivos e vinculados a uma visão do cuidar profissional, o que possivelmente é determinado pelo tipo de saber que embasa suas ações e devido a não se responsabilizarem por executar tarefas diretamente com as crianças. Resta saber se enquanto fazer das mulheres, o cuidar revelar-se-á para elas como naturalizadamente feminino ou historicamente determinado. O estudo não possibilitou apreender tal significado, quando se refere ao cuidado das crianças, necessitando para isto, pesquisas posteriores. No entanto, no que se refere ao cuidado à família, a 
visão das coordenadoras mostrou-se semelhante à das educadoras, revelando um conteúdo ideologizado em relação ao papel de mãe, à própria família idealizada enquanto espaço de ausência de conflitos e independente do contexto social, onde a mulher exerce uma função predominante de garantir o bem-estar dos membros.

É evidente a ênfase em assegurar que a atividade de cuidado realizada na creche é distinta da realizada na família, pleiteando assim um status de trabalho para o cuidado. Ao mesmo tempo, como o cuidado é valorizado somente enquanto uma etapa para a atividade nobre da educação, as educadoras apresentam uma tendência de rejeitar uma visão de si como cuidadoras, não somente quando ingressam na creche como também mais tarde.

Ademais, a contradição entre a idéia de um agir profissional e um agir real é notória quando manifestam sentimentos ambíguos, por exemplo, não querem ser substitutas da mãe, mas esperam que a criança nutra um afeto filial em relação a elas ou quando afirmam que devem ser compreensivas com a recusa alimentar da criança, mas revelam-se ansiosas quando isso ocorre.

Segundo Boehs e Patrício (1990) "cuidar abrange um conjunto de conhecimentos teóricos e práticos, fundamentados numa base científica e humanística". Pensar dessa forma daria às educadoras/cuidadoras o status necessário para re-significar o seu trabalho. Assim, esse cuidado não teria "sentido altruístico, de doação sem gratificação, mas sentido de compreender o homem, de interagir com ele" (Boehs, Patrício, 1990). Nesse sentido, o cuidado constitui-se a antítese do senso comum. Por exemplo, no caso das cotidianas desavenças entre as crianças, cuida-se compreendendo que estas acontecem, devem acontecer, isto é, são necessárias, porque decorrem de conflitos internos que a criança está vivendo. A criança tem recursos para lidar com essas situações, mas precisa da ajuda do adulto para mobilizar seus recursos. De acordo com a representação usual do cuidado, é freqüente que o adulto mantenha a criança dependente de limites externos, criando poucas oportunidades para que ela desenvolva o auto-controle e outros mecanismos para lidar com situações de conflitos. Ao adulto cabe criar estratégias para que as crianças compreendam o que estão vivendo, tanto sob o ponto de vista 
lógico, quanto relacional e emocional. Assim, seria construída intencionalmente a oportunidade para a criança conversar com a outra e conversar consigo mesma. Refletir a respeito do ocorrido, e a respeito dos próprios sentimentos, propiciando à criança a oportunidade de manter-se estreitamente ligada ao verdadeiro eu, é cuidar dela. É cuidar da sua saúde.

Além disso, a visão panorâmica dos resultados deste estudo evidencia que a criança na creche é vista a partir dos pólos educação e cuidado. O pólo da educação está legitimado no cotidiano, sendo inclusive embasado teoricamente. Além disso, é reiterado através dos treinamentos, inclusive gerando produtos específicos que são implementados e modificados. No entanto, o mesmo não acontece com o pólo cuidado, ou acontece restrito a alguns quesitos relativos a aspectos físicos.

Mesmo não tendo um corpo teórico-conceitual, o cuidado permeia o cotidiano da instituição. É possível afirmar que existe atitude de cuidado, embora ela não esteja consciente. Conhecendo as necessidades das crianças, podemos avaliar que as conseqüências desse pólo, mesmo pouco desenvolvido, são de uma qualidade que se destaca no panorama brasileiro. Portanto, é estimulante pensar sobre o que se poderia alcançar, caso a instituição se voltasse à formulação de um corpo conceitual do cuidado.

$\mathrm{Na}$ interação entre cuidar e educar, consolida-se a responsabilização pela criança. A creche assume, em parceria com a família, a formação da criança, a transformação do ser natural em um ser social, um cidadão. Por isso, as concepções de creche como um contexto de vida num espaço educativo (Bondioli, Mantovani, 1998), ou como um ambiente de cuidado e educação num contexto educativo (Kulhmann Jr, 2000) opõem-se à visão tradicional de educação como instrumental.

Acredito que a área de enfermagem pode e deve contribuir para a atenção à criança na creche e na escola, não somente realizando intervenções pontuais de controle de saúde como também ajudando a construir um referencial que possibilite a atenção integral da criança em instituições de educação. A sustentação dessa concepção tem, como ponto de partida, a característica dos primórdios da enfermagem profissional no atendimento infantil, conforme descrito por Rocha (1990). 
A respeito dos primórdios da enfermagem profissional, o livro "Notas sobre enfermagem: o que é e o que não é" de autoria de Florence Nightingale é considerado um marco da enfermagem moderna, pois mostra a possibilidade $e$ a necessidade de um preparo sistemático para a "aquisição de um conhecimento distinto daquele buscado pelos médicos, cujos fundamentos permitiriam manter o organismo em condições de não adoecer ou se recuperar de doenças" (Rocha, 1990).

Nessa obra, há um capítulo intitulado "Atendimento à criança" no qual Nightingale afirma que o conhecimento e a aplicação de certas medidas e normas que preservam a saúde da criança constitui a principal intervenção para a redução da mortalidade e morbidade infantis. Mostra uma concepção de cuidados preventivos e de promoção à saúde que deveriam ser dispensados não às crianças doentes, mas, genericamente, às crianças sadias em seus lares a fim de preservar sua saúde e prevenir para que não adoecessem. Pontua várias recomendações que denotam uma concepção de que os cuidados devem responder às necessidades de um ser em crescimento, ou seja, condições adequadas de higiene pessoal e do ambiente, alimentação e recreação, para desenvolver-se protegido de acidentes, doenças e trabalhos excessivos (Rocha, 1990).

Considerando que o cuidado efetivo não pode prescindir de uma apropriada identificação de necessidades, a pessoa que cuida deve estar receptiva às necessidades daquele que é cuidado. Para isso, à semelhança da enfermagem, a educadora pode valer-se da teoria, da ciência e tecnologia e de sua sensibilidade. Lenardt e Timm (1997) reconhecem a inspiração da metodologia feminista na abordagem inspirada na sensibilidade. Essas autoras defendem que, para tornar a prática do cuidado (em enfermagem) mais responsável e mais humana, além das ciências, precisamos aprofundar outros métodos de pensamento, o "conhecimento sensível".

A enfermagem é a ciência e a arte de cuidar. Como cuidadores e cuidadoras, nossa missão é zelar pela qualidade de vida das pessoas que cuidamos. De que adianta a vida se não pudermos garanti-la com qualidade compatível com a dignidade e com o respeito ao ser humano? De que adianta 
o progresso tecnológico, dado pelo avanço da própria ciência, se ele não estiver a serviço do bem-estar?

Desde os primórdios da enfermagem, ela se constituiu como prática voltada para o bem-estar e o conforto, independente da finalidade de cura. Para nós, importa menos saber sobre a reversibilidade diagnóstica que o bemestar e o conforto de quem cuidamos. A pessoa cuidada precisa estar bem, é o que nos basta. Tem sido assim e assim queremos que continue pois a enfermagem é imprescindível para o bem estar do outro, inclusive para garantir que o trabalho em saúde cumpra sua finalidade. Sempre haverá alguém que necessite ser cuidado e, havendo um profissional de enfermagem por perto, haverá alguém para cuidá-lo. "Cuidar é mais que um ato; é uma atitude. Portanto, abrange mais que um momento de atenção, de zelo e de desvelo. Representa uma atitude de ocupação, preocupação, de responsabilização e de envolvimento afetivo com o outro" (Boff, 1999)

Não o fazemos por caridade, pois com isso estaríamos desconsiderando o outro na relação, no que tange à sua capacidade de participar no controle do seu processo vital. Fazemo-lo com base no pilar ético da solidariedade, no qual se assenta o reconhecimento do sujeito social na sua dimensão mais nobre, ou seja, na sua capacidade de decidir, compatível com sua situação de saúde e consciência, fazendo por ele o que não puder fazer por si e com ele aquilo que tiver possibilidade de fazer. Isto é reconhecê-lo e respeitá-lo, isso é considerar sua condição de ser humano.

Collière (1989) discute que as definições de cuidado centram-se na pessoa a ajudar, "deixando na sombra os sentimentos" do cuidador e, para a autora, "cuidar é aprender a ter em conta os dois parceiros dos cuidados": o que cuida e o que é cuidado; por isso, é preciso refletir sobre as emoções e atitudes que acompanham os cuidados. Ademais, acredito, conforme Rosemberg (2000), que a creche responde às necessidades de três grupos: criança, mãe/pai, e funcionários. Nas palavras de uma coordenadora:

O cuidado não termina na criança. Eu tenho que considerar o adulto, cuidar também das relação dos adultos e das crianças, cuidar das nossas relações enquanto cuidadores e educadores. 
Bondioli e Mantovani (1998) relatam que, nas creches de Parma, impressiona "o clima de flexibilidade, a alegria e a vivacidade do pessoal, o conhecimento extremamente individualizado das crianças, a real abertura à família. A exigência do próprio bem-estar, do próprio prazer de estar com as crianças torna as pessoas disponíveis às exigências dos outros adultos. Isso é evidenciado na naturalidade com a qual os coordenadores voltam à atividade com as crianças".

Um novo referencial de atendimento à criança, o cuidado à criança sadia, que concebe a creche como um direito da criança, um espaço de vida e saúde, de interações, de descobertas e aprendizagem. É o enfoque de promover a saúde da criança, numa perspectiva de superar a noção de creche como um risco ao desenvolvimento infantil.

De acordo com o previsto na Lei de Diretrizes e Bases da Educação Nacional, e conforme tem sido norteada a ação da Coseas, as creches têm como finalidade o "atendimento em educação infantil contemplando as necessidades de desenvolvimento intelectual e o acesso ao saber, bem como o direito à socialização, às vivências infantis e aos cuidados assistenciais específicos e necessários". Para atingir tal finalidade, repensar o significado das creches nas universidades públicas, ou seja, no centro produtor e disseminador do saber científico, implica minimamente repensar o saber que deve nortear o desenvolvimento intelectual e a socialização (Fonseca, 2000). 
Ariès P. História social da criança e da família. $2^{\mathrm{a}}$ ed. Rio de Janeiro: Zahar; 1981.

Arruda EN, Zagonel IPS. A pesquisa-cuidado como uma abordagem filosófica para o desenvolvimento do conhecimento em enfermagem. Texto Contexto Enferm 1997; 6(3): 161-176.

Avancini M. Pesquisa mostra má qualidade de creches. O estado de São Paulo 2000 out 30; Caderno A:7.

Badinter E. Um amor conquistado: o mito do amor materno. Rio de Janeiro: Nova Fronteira; 1985.

Bardin L. Análise de conteúdo. Lisboa: Edições70; 1977.

Barreto AMRF. Por que e para que uma política de formação do profissional de educação infantil? In: Ministério da Educação e do Desporto (BR). Secretaria de Educação Fundamental. Por uma política de formação do profissional de educação infantil. Brasília (DF): COEDI/MEC; 1994.

Barros AJD, Gonçalves EV, Borba CRS de, Lorenzatto CS, Motta DB, Silva VRL da, et al. Perfil das creches de uma cidade de porte médio do sul do Brasil: operação, cuidados, estrutura física e segurança. Cad Saúde Públ 1999; 15(3): 597-604.

Boehs AE, Patrício ZM. O que é este "cuidar/cuidado" - uma abordagem inicial. Rev Esc Enferm USP 1990; 24(1): 111-116.

Boff L. Saber cuidar: ética do humano - compaixão pela terra. Petrópolis: Vozes; 1999.

Bondioli A, Mantovani S. Manual de educação infantil: de 0 a 3 anos - uma abordagem reflexiva. Trad de Rosana Severino Di Leone e Alba Olmi. 9a ed. Porto Alegre: Artes Médicas; 1998. Introdução; p. 13-37.

Bonomi A. O relacionamento entre educadores e pais. In: Bondioli A, Mantovani S. Manual de educação infantil: de 0 a 3 anos - uma abordagem reflexiva. Trad 
de Rosana Severino Di Leone e Alba Olmi. 9aㅗ ed. Porto Alegre: Artes Médicas; 1998. Cap. 9, p.161-72.

Bowlby J. Maternal care and mental health. New York: Schocken Books; 1966.

Campos MM. Educação infantil no primeiro mundo: uma visão daqui debaixo do equador. In: Rosemberg F, Campos MM, organizadores. Creches e préescolas no hemisfério norte. São Paulo: Cortez / Fundação Carlos Chagas; 1994. p.323-48.

Campos MM. Educar e cuidar: questões sobre o perfil do profissional de educação infantil. In: Ministério da educação e do Desporto(BR). Secretaria de Educação Fundamental. Por uma política de formação do profissional de educação infantil. Brasília: COEDI/MEC; 1994. p. 32-42.

Carlotto CM. Metodologia de trabalho com mulheres. São Paulo: Sempre Viva Organização e Formação; 1991. /Mimeografado/.

Carneiro F, Agostini M. Oficinas de reflexão - espaços de liberdade e saúde. Esc Nac Saúde Públ: Fund Oswaldo Cruz; 1993. /Mimeografado/.

Chamboredon J-C, Prevòt J. O "ofício de criança": definição social da primeira infância e funções diferenciadas da escola maternal. Cad Pesq 1986; (59): $32-$ 56.

Chiesa AM. O uso de estratégias participativas para o conhecimento das representações sociais de mulheres da região de Pirituba / Perus com resultado classe III de Papanicolau.[dissertação]. São Paulo(SP): Faculdade de Saúde Pública da USP; 1993.

Cipollone L. A atualização permanente nas creches. In: Bondioli A, Mantovani S. Manual de educação infantil: de 0 a 3 anos - uma abordagem reflexiva. Trad de Rosana Severino Di Leone e Alba Olmi. 9aㅡ ed. Porto Alegre: Artes Médicas; 1998. Cap. 7, p. 121-39.

Collière MF. Invisible care and invisible women as health care-providers. Int $\mathrm{J}$ Nurs Stud 1986;23(2): 95-112. 
Conselho Nacional de Credenciamento de Creches (Austrália). Sistema de Promoção de Qualidade e Credenciamento. Priorizando as crianças. Trad de Ricardo Fagundes Carvalho. s/d.

Conselho Nacional dos Direitos da Mulher. Creche urgente: Relatos de experiências. Brasília; 1988 (Série de Manuais Sobre Creche, v.7).

Costa JF. Ordem médica e norma familiar. $3^{\underline{a}}$ ed. Rio de Janeiro: Edições Graal; 1989.

Costenaro RGS, Daros A, Arruda EN. O cuidado na perspectiva do acompanhante de crianças e adolescentes hospitalizados. Esc Anna Nery Rev Enferm 1998; 2 (1/2).

Demo P. Formação do profissional infantil: alguns desafios do ponto de vista formativo. 2º Simpósio Nacional de Educação Infantil; 1996 nov. Brasília. (mesa redonda).

Demo P. Educação e qualidade. Campinas: Papirus; 1995.

Demo E. Metodologia do conhecimento científico. São Paulo: Atlas; 2000.

Dutoit RA. A formação do educador de creche na dinâmica da construção do projeto educacional. [dissertação]. São Paulo (SP): Faculdade de educação da USP; 1995.

Erikson EH. Infância e sociedade. Rio de Janeiro: Zahar; 1971.

Farr R. Representações sociais: a teoria e sua história. In: Guareshi P, Jovchelovitch S, organizadores. Textos em representações sociais. $5^{\underline{a}}$ ed. Petrópolis: Vozes; 1999.

Ferreira $\mathrm{ABH}$. Novo dicionário da língua portuguesa. $2^{\mathrm{a}}$ ed. Rio de Janeiro: Nova Fronteira; 1986.

Fonseca, RMGS da. Abertura do I Seminário "As creches públicas nas universidades paulistas. [Apresentado ao I Seminário "As creches públicas nas universidades paulistas; 2000, set 15; Campinas.] 
Fonseca, RMGS da. Mulheres e enfermagem: uma construção generificada do saber. [livre docência]. São Paulo(SP):Escola de Enfermagem da USP; 1996.

Freire P. Pedagogia do oprimido. 13 ${ }^{\underline{a}}$ ed. Rio de Janeiro: Paz e Terra; 1983. Cap. 2, p. 63-87.

Freyre G. Casa grande e senzala. Rio de Janeiro: José Olympio; 1978.

Fry ST. The philosophical foundations of caring. In: Leininger MM. Ethical and moral dimensions of care. Detroit: Wayne State University Press; 1990. Cap. 1, p. 13-24.

Gaut D. A theoretic description of caring as action. In: Leininger MM. Caring: the essence of nursing and health. Thorofore: Slack; 1984. Cap. 3, p. 27-44.

Ghedini PO. Entre a experiência e os novos projetos: a situação da creche na Itália. Trad de Maria Malta Campos. In: Rosemberg F, Campos MM, organizadores. Creches e pré-escolas no hemisfério norte. São Paulo: Cortez I Fundação Carlos Chagas; 1994. Cap. 4, p. 189-210.

Gonzaga ML de C, Neves-Arruda E. Fontes e significados de cuidar e não cuidar em hospital pediátrico. Rev Lat Am Enferm 1998; 6(5):17-26.

Harrison AA. A psicologia como ciência social. Trad de Álvaro Cabral. São Paulo: Cultrix/EDUSP; 1975.

Henderson V. Princípios básicos sobre cuidados de enfermagem. Trad de Anyta Alvarenga. São Paulo: Cortez; 1989.

Ignácio RK. Criança querida: o dia-a-dia das creches e jardim-de-infância. São Paulo: Antroposófica; 1995.

Jodelet D. La representación social: fenómenos, concepto y teoría. In: Moscovici S. Psicologia social II. Barcelona: Paidós; 1986. p.469-94.

Kramer S. A política do pré-escolar no Brasil. A arte do disfarce. Rio de Janeiro: Achiame; 1984.

Kramer S. O papel social da pré-escola. Cad Pesq 1985; 58: 78-81. 
Kuhlmann Jr M. Instituições pré-escolares assistencialistas no Brasil (18991922). Cad Pesq 1991; 78:17-26.

Kulhmann Jr M. Educação infantil e currículo. In: Faria ALG de, Silveira MS, organizadores. Educação infantil pós-LDB: rumos e desafios. $2^{\underline{a}}$ ed. Campinas (SP): Autores Associados - FE/UNICAMP; 2000. Cap. 3, p. 51-66.

Lane STM. Uso e abusos do conceito de representação social. In: Spink MJ, organizador. O conhecimento no cotidiano: as representações sociais na perspectiva da psicologia social. São Paulo: Brasiliense; 1993. p. 58-71.

Leininger MM. Care: the essence of nursing and health. Detroit: Wayne State University Press; 1988a. Care: the essence of nursing and health. Cap. 1, p. 315.

Leininger MM. Care: the essence of nursing and health. Detroit: Wayne State University Press; 1988b. Caring: a central focus of nursing and health care services. Cap. 4, p. 45-59.

Leininger MM. Care: the essence of nursing and health. Detroit: Wayne State University Press; 1988c. Caring is nursing: understanding the meaning, importance and issues. Cap. 7, p. 83-93.

Lenardt MH, Timm M. Conhecimento em enfermagem: uma reflexão, por encanto, por enquanto. Cogitare Enferm 1997; 2(2): 39-42.

Machado ML. Pré escola é ou não é escola: a busca de um caminho. São Paulo: Paz e Terra; 1991.

Mantovani S, Terzi N. A inserção. In: Bondioli A, Mantovani S. Manual de educação infantil: de 0 a 3 anos - uma abordagem reflexiva. Trad de Rosana Severino Di Leone e Alba Olmi. 9ª ed. Porto Alegre: Artes Médicas; 1998. Cap. 10, p. 173-184.

Maranhão DG. Colo: um cuidado que educa. Avisa lá 1999; 1:5-6.

Maranhão DG. O cuidado como elo entre a saúde e a educação: um estudo de caso no berçário de uma creche.[dissertação]. São Paulo(SP): UNIFESP; 1998. 
Marcílio ML. História social da criança abandonada. São Paulo: HUCITEC; 1998.

Mayeroff M. On caring. New York: Harper\& Row; 1971.

Mello AM de A. História da Carochinha: uma experiência para educação de crianças abaixo de 3 anos em creche. [dissertação]. Ribeirão Preto(SP): Faculdade de Filosofia, Letras e Ciências Humanas da USP; 1999.

Merhy EE. A perda da dimensão cuidadora na produção da saúde: uma discussão do modelo assistencial e da intervenção no seu modo de trabalhar a assistência. Campinas; 1997. /Mimeografado/.

Merisse A. Origem das instituições de atendimento à criança: o caso das creches. In: Merisse A, Justo JS, Rocha LC da, Vasconcelos MS. Lugares da infância: reflexões sobre a história da criança na fábrica, creche e orfanato. São Paulo: Arte Ciência; 1997. p. 25-51

Minayo MC de S. O desafio do conhecimento: pesquisa qualitativa em saúde. $2^{a}$ ed. São Paulo: HUCITEC-ABRASCO; 1993.

Ministério da Educação e do Desporto(BR). Secretaria de Educação Fundamental. Referencial curricular nacional para a educação infantil. Brasília 1998a. Introdução; v. 1.

Ministério da Educação e do Desporto(BR). Secretaria de Educação Fundamental. Referencial curricular nacional para a educação infantil. Brasília 1998b. Formação pessoal e social; v. 2.

Ministério da Educação e do Desporto(BR). Secretaria de Educação Fundamental. Referencial curricular nacional para a educação infantil. Brasília 1998c. Conhecimento de mundo; v. 3.

Musatti T. Modalidades e problemas do processo de socialização entre crianças na creche. In: Bondioli A, Mantovani S. Manual de educação infantil: de 0 a 3 anos - uma abordagem reflexiva. Trad de Rosana Severino Di Leone e Alba Olmi. 9ª ed. Porto Alegre: Artes Médicas; 1998. Cap. 11, p. 189-201. 
Mussen PH, Conger JJ, Kagan J. Desenvolvimento e personalidade da criança. São Paulo: Harper Row; 1977.

Nascimento MEP do. Os profissionais da educação infantil e a nova Lei de Diretrizes e Bases da Educação Nacional. In: Faria ALG de, Silveira MS, organizadores. Educação infantil pós-LDB: rumos e desafios. $2^{2}$ ed. Campinas (SP): Autores Associados - FE/UNICAMP; 2000. Cap. 5, p. 99-112.

Neves-Arruda E, Bittencourt M dos S, Gonçalves FA. Atributos profissionais dos cuidadores da pessoa com câncer: perspectivas de enfermeiras. Cogitare Enferm 1996; 1(1):85-90.

Palhares MS, Martinez CMS. A educação infantil: uma questão para o debate. In: Faria ALG de, Silveira MS, organizadores. Educação infantil pós-LDB: rumos e desafios. $\quad 2^{\mathrm{a}}$ ed. Campinas: Autores Associados - FE/UNICAMP; 2000. Cap. 1, p. 5-18.

Pascal C, Bertram A. A educação de crianças pequenas e de seus professores em três países europeus. Trad de Tina Amado. In: Rosemberg F, Campos MM, organizadores. Creches e pré-escolas no hemisfério norte. São Paulo: Cortez/ Fundação Carlos Chagas; 1994.

Patrício ZM. O processo de trabalho da enfermagem frente às novas concepções de saúde: repensando o cuidado/propondo o cuidado (holístico). Texto Contexto Enferm 1993; 2(1): 67-81.

Phillips P. A desconstruction of caring. J Adv Nurs 1993; 8(2):1554-58.

Piccolo J. Mães que acompanham o filho hospitalizado: percepções da equipe de enfermagem. [Monografia Conclusão de Curso]. São Paulo (SP): Escola de Enfermagem da USP; 1998.

Piotto DC, Rosseti-Ferreira MC, Chaguri AC, Mello AM, Silva AP, Eltink $C$ et al. Promoção da qualidade e avaliação na educação infantil: contribuições da experiência com um instrumento australiano para a discussão brasileira. Ribeirão Preto (SP); s/d. /Mimeografado/. 
Ribeiro JM, Koerich C da L, Neves-Arruda E. Conforto na hospitalização: a perspectiva infanto-juvenil. Cogitare Enferm 1997; 2(2):59-64.

Robertson J, Robertson J. Substitute mothering. Nursing Times; 1973.

Rocha SM de M. O processo de trabalho em saúde e a enfermagem pediátrica: socialidade e historicidade do conhecimento. [livre-docência]. Ribeirão Preto (SP): Escola de Enfermagem da USP; 1990.

Rogers CR. Liberdade para aprender. 4 ${ }^{\mathrm{a}}$ ed. Trad de Edgar Godoi da Mata Machado e Márcio Paula de Andrade. Belo Horizonte: Interlivros; 1978.

Romaña MA. Construção coletiva do conhecimento através do psicodrama. Campinas: Papirus; 1992.

Rosemberg F, Campos MM, Pinto RH. Creches e pré-escolas. São Paulo: Nobel/Conselho Estadual da Condição Feminina; 1985.

Rosemberg F. A função da creche nas universidades [Apresentado ao I Seminário "As creches públicas nas universidades paulistas; 2000, set 15; Campinas.]

Rosemberg F. Formação precária na pré-escola.[online]. Disponível em: $<$ http://www.sinpro-rs.org.br/extra/jun98/educa1.htmp (14 maio 2001).

Rosseti-Ferreira MC. O apego e as reações da criança à separação da mãe. Cad Pesq 1984; 48:3-19.

Rosseti-Ferreira MC, Amorin KS, Vitoria T. A creche enquanto contexto possível de desenvolvimento da criança pequena. Rev Bras Cresc Desenvolv Hum 1994; 4(2).

Rossi MJ dos S. O curar e o cuidar - a história de uma relação: um ensaio. Rev Bras Enferm 1991; 44(1): 16-21.

Saitta LR. Coordenação pedagógica e trabalho em grupo. In: Bondioli A, Mantovani S. Manual de educação infantil: de 0 a 3 anos - uma abordagem 
reflexiva. Trad de Rosana Severino Di Leone e Alba Olmi. 9a ed. Porto Alegre: Artes Médicas; 1998. Cap. 6, p. 114-20.

Sawaia BB. A consciência em construção no trabalho da construção da existência. [doutorado]. São Paulo (SP): Faculdade de Psicologia da PUC; 1987.

Sigaud CH de S, Veríssimo M De La Ó R. Enfermagem pediátrica: o cuidado de enfermagem à criança e ao adolescente. São Paulo: EPU; 1996. O ser criança. Cap. 1, p. 11-4.

Souza Filho EA de. Análise da representações sociais. In: Spink MJ, organizadores. O conhecimento no cotidiano: as representações sociais na perspectiva da psicologia social. São Paulo: Brasiliense; 1993. p. 109-45.

Spaggiari S. Considerações críticas e experiências de gestão social. In: Bondioli A, Mantovani S. Manual de educação infantil: de 0 a 3 anos - uma abordagem reflexiva. Trad de Rosana Severino Di Leone e Alba Olmi. 9aㅡ ed. Porto Alegre: Artes Médicas; 1998. Cap. 5, p. 96-113.

Universidade de São Paulo(BR). Coordenadoria de assistência social. Divisão de creches. Apresentando a creche central. São Paulo; 1999.

Waldow VR. Cuidado: uma revisão teórica. Rev Gaúcha Enferm 1992; 13(2): 29-35.

Waldow VR. Cuidado humano e a enfermagem: ampliando sua interpretação. Esc Anna Nery Rev Enferm 1997; 1(2):142-53.

Waldow VR. Cuidado humano: o resgate necessário. Porto Alegre: Sagra / Luzzatto; 1998.

Waldow VR. Cuidar/cuidado: o domínio unificador da enfermagem. In: Waldow VR, Lopes MJM, Meyer DE. Maneiras de cuidar, maneiras de ensinar: a enfermagem entre a escola e a prática profissional. Porto Alegre: Artes Médicas; 1995. Cap. 1, p. 7-30. 
Wallon H. As origens do caráter da criança. Trad de Heloysa Dantas de Souza Pinto. São Paulo: Nova Alexandria; 1995. Estimulações orgânicas e diversidade das emoções. Cap. 7, p. 119-33.

Wilheim AM, coordenador. Questão social, políticas sociais no Brasil, avaliação e propostas para os anos 90: creche e educação básica. São Paulo: Fundap; 1991. 


\section{ANEXO 1}

\section{Formulário para caracterização das informantes do estudo.}

Nome:

Idade:

Sexo:

Escolaridade:

(última série cursada ou em curso)

Profissão:

Função atual na creche:

(Preencher a ficha de identificação familiar)

Tem ou teve filhos na creche onde trabalha? ( ) $\operatorname{sim}$ ( ) não

Grupo etário com que trabalha na creche atualmente:

Você teve algum tipo de capacitação específica para o trabalho em educação infantil? Se sim, de que forma?

Há quanto tempo você trabalha com educação infantil?

Há quanto tempo você trabalha nesta creche?

Você trabalhou/trabalha em outros locais que não esta creche? Se sim, o que fez/faz e durante quanto empo?

locê teve outras experiências de cuidar de crianças (filhos ou outros)?

¿ue expectativas você tem em relação a seu trabalho? Deseja mudar?

¿uma opção sua trabaihar na creche ou foi a opção possível? 


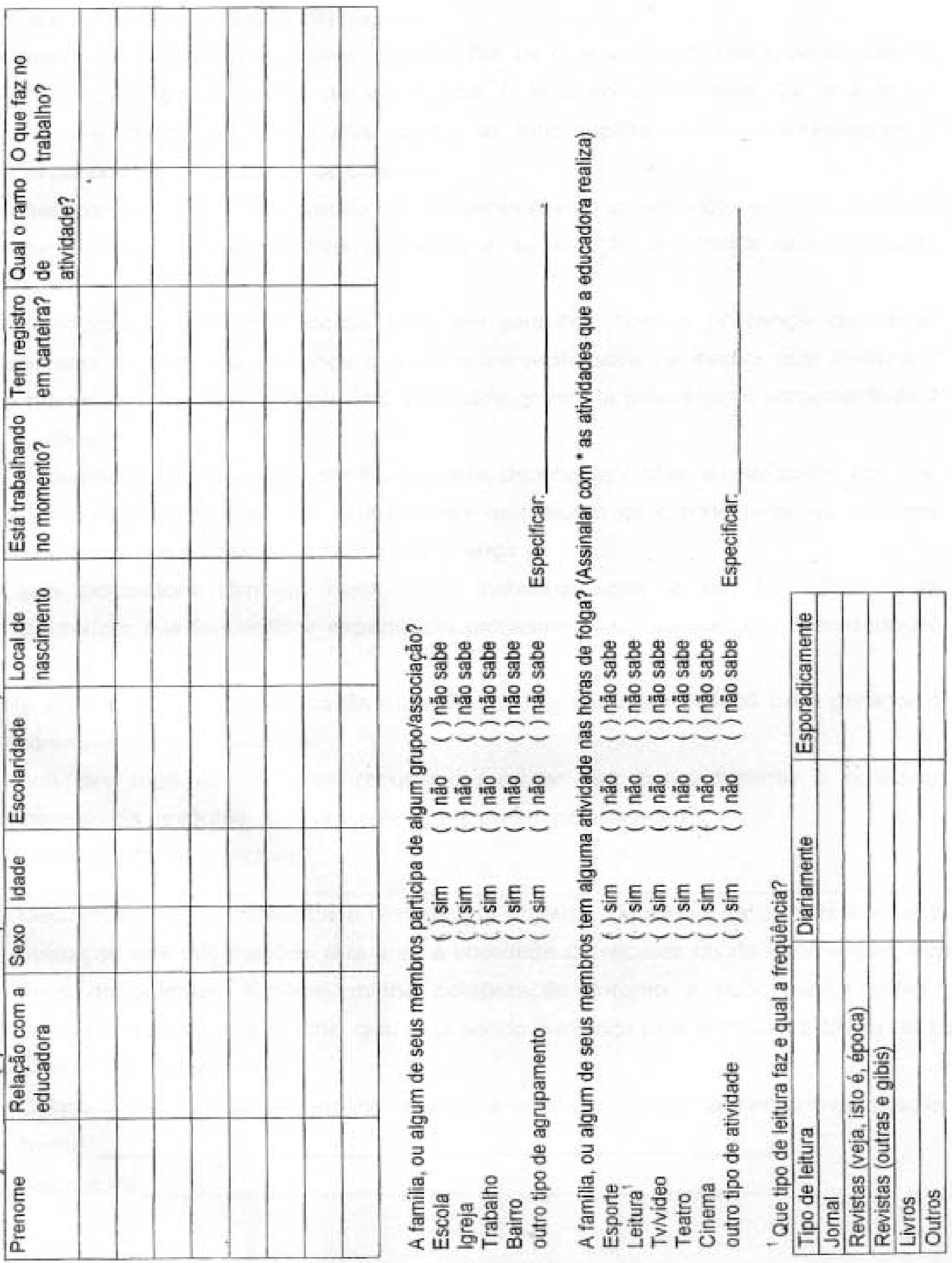




\section{ANEXO $2 \mathrm{~A}$}

Termo de consentimento livre e esclarecido

Prezada (nome da educadora).

Como você já sabe, meu nome é Maria De La Ó e sou professora da Escola de Enfermagem. Estou realizando um estudo a respeito do cuidado da criança na creche e, para isso, farei uma coleta de informações com as educadoras e coordenadoras das creches da COSEAS.

A finalidade do trabalho é aprofundar o conhecimento sobre o cuidado da criança e assim oferecer subsídios para a melhoria da atenção à criança que freqüenta creche.

A participação das educadoras será em reuniões com a presença de várias educadoras, a minha presença e a de outra professora da escola que ajudará a conduzir as reuniões. Está previsto que cada grupo de educadoras participará de 4 reuniões.

As reuniões serão gravadas em fita cassete, depois transcritas e analisadas por mim a fim de identificar como as profissionais que atuam na creche junto às crianças compreeendem e realizam o cuidado à criança.

Cada educadora também responderá individualmente a um formulário para caracterizar sua formação e experiência profissional ou pessoal com o cuidado de crianças.

$\mathrm{Na}$ apresentação do relatório da pesquisa, serão seguidos passos para garantir o anonimato das participantes.

Você tem total liberdade de recusar ou retirar seu consentimento a qualquer momento da pesquisa, sem que isso implique em penalização.

Você gostaria de participar?

Declaro ter sido esclarecida a respeito do objetivo, da forma de participação e de utilização das informações e quanto à liberdade de recusar ou de interromper, sem ônus de qualquer espécie, minha colaboração durante a investigação sobre o cuidado da criança na creche, que está sendo realizada pela professora Maria De La Ó Ramallo Veríssimo.

Concordo em participar como informante na coleta de dados para essa investigação. Nome

Assinatura 


\section{ANEXO 2 B}

\section{Termo de consentimento livre e esclarecido}

Prezada (nome da coordenadora).

Como você já sabe, meu nome é Maria De La Ó e sou professora da Escola de Enfermagem. Estou realizando um estudo a respeito do cuidado da criança na creche e gostaria de entrevistar as educadoras e coordenadoras das creches da Coseas para esse estudo.

A finalidade do trabalho é aprofundar o conhecimento sobre o cuidado da criança e assim oferecer subsídios para a melhoria da atenção à criança que freqüenta creche.

A participação das coordenadoras consiste em responder a entrevistas individuais, realizadas por mim. Serão solicitadas informações que visam caracterizar sua formação e experiência profissional ou pessoal com o cuidado infantil e sobre experiências de trabalho que possibilitem identificar como as profissionais que atuam na creche junto às crianças compreeendem e realizam o cuidado. As entrevistas serão gravadas em fita cassete, depois transcritas e analisadas.

$\mathrm{Na}$ apresentação do relatório da pesquisa, serão seguidos passos para garantir o anonimato das participantes.

Você tem total liberdade de recusar ou retirar seu consentimento a qualquer momento da pesquisa, sem que isso implique em penalização.

Você gostaria de participar?

Declaro ter sido esclarecida a respeito do objetivo, da forma de participação e de utilização das informações e quanto à liberdade de recusar ou de interromper, sem ônus de qualquer espécie, minha colaboração durante a investigação sobre o cuidado da criança na creche, que está sendo realizada pela professora Maria De La Ó Ramallo Veríssimo.

Concordo em participar como informante nas entrevistas referentes a essa investigação.

Nome

Assinatura 


\section{UNIVERSIDADE DE SÃO PAULO ESCOLA DE ENFERMAGEM \\ Av. Dr. Eneas de Carvalho Aguiar, 419 - CEP 05403-000 \\ 2 Fone: 3066-7548 - Fax: 280-8213 \\ C.P. 41633 - CEP 05422-970-e-mail.: ee@edu.usp br}

São Paulo, 22 de março de 2000.

Ilma. Sra.

PROFA. MARIA DE LA Ó RAMALLO VERÍSSIMO

Ref.: Processo $n^{\circ} 46 / 2000$

Em atenção à solicitação referente à análise do projeto "A representação social de educadoras de creche acerca do cuidado da criança", informamos que o mesmo foi considerado aprovado pelo Comitê de Ética em Pesquisa da Escola de Enfermagem da Universidade de São Paulo (CEP/EEUSP).

Analisado sob o aspecto ético-legal, atende às exigências da Resolução n 196/96 do Conselho Nacional de Saúde.

Esclarecemos que após o término da pesquisa, os resultados obtidos deverão ser encaminhados ao CEP/EEUSP, para serem anexados ao processo.

Atenciosamente,

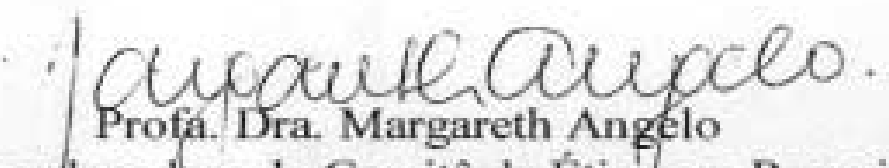

Coordenadora do Comitê de Éticà em Pesquisa

da Escola de Enfermagem da Universidade de São Paulo 


\section{ANEXO 4}

Programação da oficina desenvolvida junto às educadoras das creches

\begin{tabular}{|c|l|l|l|}
\hline Encontro & Tema & Objetivo & Estratégia facilitadora \\
\hline $1^{\circ}$ & O trabalho realizado & $\begin{array}{l}\text { Identificar e refletir sobre o conhecimento e } \\
\text { as práticas das educadoras relativos ao } \\
\text { cuidado das crianças }\end{array}$ & $\begin{array}{l}\text { Uso de sucata para representação do trabalho } \\
\text { realizado no cotidiano, destacando o que é o } \\
\text { cuidado }\end{array}$ \\
\hline $2^{0}$ & $\begin{array}{l}\text { Facilidades, dificuldades e } \\
\text { sentimentos relativos ao } \\
\text { cuidado }\end{array}$ & $\begin{array}{l}\text { Identificar e refletir sobre as facilidades, as } \\
\text { dificuldades e os sentimentos das } \\
\text { educadoras relativos ao cuidado da criança }\end{array}$ & $\begin{array}{l}\text { Construção de painel com colagem de figuras } \\
\text { de revistas, destacando as facilidades, as } \\
\text { dificuldades e os sentimentos relativos ao } \\
\text { cuidado da criança }\end{array}$ \\
\hline $3^{0}$ & $\begin{array}{l}\text { O enfrentamento das } \\
\text { dificuldades }\end{array}$ & $\begin{array}{l}\text { Identificar e refletir sobre as estratégias de } \\
\text { enfrentamento utilizadas pelas educadoras } \\
\text { para lidar com as dificuldades encontradas } \\
\text { no cotidiano }\end{array}$ & $\begin{array}{l}\text { Dramatização estruturada sobre um ambiente } \\
\text { de trabalho compatível com as necessidades } \\
\text { das crianças }\end{array}$ \\
\hline $4^{0}$ & $\begin{array}{l}\text { Perspectivas: a } \\
\text { reinvenção do cuidado da } \\
\text { criança na creche }\end{array}$ & $\begin{array}{l}\text { Identificar e refletir sobre os caminhos e } \\
\text { meios para a reconstrução do cuidado da } \\
\text { criança na creche }\end{array}$ & $\begin{array}{l}\text { Construção com fios coloridos representando } \\
\text { os caminhos e meios para reconstruir o } \\
\text { cuidado da criança na creche }\end{array}$ \\
\hline
\end{tabular}




\section{Anexo 5}

\section{Avaliações das educadoras sobre a oficina pedagógica}

Quando a gente fala e você também fala com a gente, acaba contando um pouco, o particular, seu ponto de vista. É bem legal esse encontro, seria legal que todo mundo viesse.

Valeu a pena, muito. Apesar de eu ter deixado as minhas filhas com o pai, todo mundo lá, eu gostei prá caramba, não pensei que fosse assim. Se tiver outra oportunidade pode convidar.

Seria muito interessante que mais pessoas tivessem vindo. E até uma idéia de se levar prá fora. Um encontro em que ninguém estava preocupado em ir de acordo com a metodologia, estava se expondo mesmo, que é tão difícil, sabe? Então não estou respondendo aquilo que ela quer ouvir. A gente não exercita isso no dia-a-dia, nem nas nossas formações, nos nossos encontros.

Foi tão produtivo, passou tão rápido o tempo. Mais produtivo esse encontro do que os encontros que tem no meio do ano, sabe? E a gente falando pode estar revendo também o que a gente pode melhorar. É um momento de reflexão e crescimento. Porque isso é que vai mudando, vai encaminhando, é muito bom mesmo.

Hoje, eu fiquei emocionada de ouvir que, mesmo que as vezes a gente não fale, outras pessoas pensam como a gente. E eu me senti muito emocionada de saber que as outras pessoas estavam sentindo o mesmo que eu, se incomodando com a situação. Almejando uma situação melhor. Eu me senti emocionada hoje, essa é a palavra.

Também gostei muito, vocês estão de parabéns, se vocês precisarem, com certeza eu estarei aqui.

Eu gosto muito de dramatizar, tocar uma música, e tem a letra do Gonzaguinha que fala: "eu fico com a pureza da resposta da criança, é a vida, é bonita, é bonita”, e retrata tudo isso. Tudo o que a gente discutiu, falou, confrontou, questionou, criticou, elogiou. É tão bonito, a nossa profissão, o nosso trabalho, apesar de ter acontecido uma série de coisa, mas é bonito parar e contar. Quando uma pessoa pára prá te ouvir: o que é o seu trabalho? Como é o seu trabalho? Como você fez esse trabalho? Que sentimentos te traz isso? Eu gostei, todo mundo está de parabéns, se esforçou e parabéns, espero que a tese seja bem sucedida.

Eu estou muito contente de saber que a gente, apesar de ser uma pesquisa, mas a gente cria esse elo com a saúde, e espero que não fique só na pesquisa, que possa ser propagada, que realmente a gente consiga alcançar o que a gente está almejando. E eu fiquei bastante surpresa de saber que a gente ainda encontra pessoas que discutem com transparência. Porque muitas coisas às vezes são ditas, mas sem clareza. Eu acho que vocês foram bastante claras. Foram transparentes na colocação, e saber que estamos também discutindo politicamente, é muito importante. Porque não fica só uma coisa da pesquisa, do papel, tem uma discussão política, e a gente sabe que nesse país a política é muito importante. Temos que avançar nas reflexões. E pode convidar, eu quero se possível ir na sua defesa de tese. 